\title{
MDPI
}

\section{Transitioning to DECENT WORK AND ECONOMIC GROWTH}

Philipp Aerni, Marianthe Stavridou and Isabelle Schluep (Eds.) 
Transitioning to
Decent Work
and Economic Growth 


\title{
Transitioning to Sustainability Series: Volume 8
}

\author{
Series Editor: Manfred Max Bergman
}

Volumes in the series:

Volume 1: Transitioning to No Poverty

ISBN 978-3-03897-860-2 (Hbk);

ISBN 978-3-03897-861-9 (PDF)

Volume 2: Transitioning to Zero Hunger ISBN 978-3-03897-862-6 (Hbk);

ISBN 978-3-03897-863-3 (PDF)

Volume 3: Transitioning to Good Health and Well-Being

ISBN 978-3-03897-864-0 (Hbk);

ISBN 978-3-03897-865-7 (PDF)

Volume 4: Transitioning to Quality

Education

ISBN 978-3-03897-892-3 (Hbk);

ISBN 978-3-03897-893-0 (PDF)

Volume 5: Transitioning to Gender Equality ISBN 978-3-03897-866-4 (Hbk);

ISBN 978-3-03897-867-1 (PDF)

Volume 6: Transitioning to Clean Water and Sanitation

ISBN 978-3-03897-774-2 (Hbk);

ISBN 978-3-03897-775-9 (PDF)

Volume 7: Transitioning to Affordable and Clean Energy

ISBN 978-3-03897-776-6 (Hbk);

ISBN 978-3-03897-777-3 (PDF)

Volume 8: Transitioning to Decent Work and Economic Growth

ISBN 978-3-03897-778-0 (Hbk);

ISBN 978-3-03897-779-7 (PDF)

Volume 9: Transitioning to Sustainable Industry, Innovation and Infrastructure ISBN 978-3-03897-868-8 (Hbk);

ISBN 978-3-03897-869-5 (PDF)
Volume 10: Transitioning to Reduced Inequalities

ISBN 978-3-03921-160-9 (Hbk);

ISBN 978-3-03921-161-6 (PDF)

Volume 11: Transitioning to Sustainable Cities and Communities

ISBN 978-3-03897-870-1 (Hbk);

ISBN 978-3-03897-871-8 (PDF)

Volume 12: Transitioning to Responsible Consumption and Production ISBN 978-3-03897-872-5 (Hbk); ISBN 978-3-03897-873-2 (PDF)

Volume 13: Transitioning to Climate Action ISBN 978-3-03897-874-9 (Hbk); ISBN 978-3-03897-875-6 (PDF)

Volume 14: Transitioning to Sustainable Life below Water

ISBN 978-3-03897-876-3 (Hbk);

ISBN 978-3-03897-877-0 (PDF)

Volume 15: Transitioning to Sustainable Life on Land

ISBN 978-3-03897-878-7 (Hbk);

ISBN 978-3-03897-879-4 (PDF)

Volume 16: Transitioning to Peace, Justice and Strong Institutions

ISBN 978-3-03897-880-0 (Hbk);

ISBN 978-3-03897-881-7 (PDF)

Volume 17: Transitioning to Strong Partnerships for the Sustainable

Development Goals

ISBN 978-3-03897-882-4 (Hbk);

ISBN 978-3-03897-883-1 (PDF) 
Philipp Aerni, Marianthe Stavridou and Isabelle Schluep (Eds.)

\section{Transitioning to Decent Work and Economic Growth}

Transitioning to Sustainability Series 
EDITORS

Philipp Aerni, Marianthe Stavridou

and Isabelle Schluep

Center for Corporate Responsibility and

Sustainability (CCRS);

University of Zurich, Switzerland
EDITORIAL OFFICE

MDPI

St. Alban-Anlage 66

4052 Basel

Switzerland

For citation purposes, cite each article independently as indicated below:

Author 1, and Author 2. 2021. Chapter Title. In Transitioning to Decent Work and Economic Growth. Edited by Philipp Aerni, Marianthe Stavridou and Isabelle Schluep. Transitioning to Sustainability Series 8. Basel: MDPI, Page Range.

Published with the generous support of the Swiss National Science Foundation.

(C) 2021 by the authors. Chapters in this volume are Open Access and distributed under the Creative Commons Attribution (CC BY 4.0) license, which allows users to download, copy and build upon published articles, as long as the author and publisher are properly credited, which ensures maximum dissemination and a wider impact of our publications. 


\section{Contents}

About the Editors vii

Contributors ix

Abstracts $\quad$ xi

$1 \quad$ Preface to Transitioning to Decent Work and Economic Growth 1

ISABELLE SCHLUEP, PHILIPP AERNI AND MARIANTHE STAVRIDOU

2 Economic Development and Cultural Change:

The Role of Multinational Enterprises in Mexico's Emerging Dual

Economy (1970s to 2000s)

ALEX GERTSCHEN

3 Challenges for the Host Society-Human Trafficking, Slavery and

Abuse in the Work Context

MARIA ELO AND ARLA JUNTUNEN

4 "Business as Part of the Solution":

SDG 8 Challenges Popular Views in the Global Sustainability Discourse PHILIPP AERNI

$5 \quad$ Memories of a Practitioner:

Ciba-Geigy Crop Protection Activities in Indonesia in the 1980s, an Example of Local Embeddedness

DINO SOZZI

6 Multilevel Sustainability Tensions of MNEs in Developing Countries LIA FERRINI

7 Agriculture in the Face of Climate Change:

Sustained and Inclusive Economic Growth as a Prerequisite for

Sustainable Development

ROMANO DE VIVO, ETTORE CAPRI, HENRI RUEFF, ANTONIO GAUDIOSO, ALEXANDRU MARCHIS, AND GIANPIERO MENZA

8 Employment Gender Gap in the Renewable Energy Sector

SUMON VANGCHUAY AND AMANDA NIKLAUS

$9 \quad$ "Me muess d'Lüt neh wie si sy-Anderi gits e keini".

Decent Work and Sustainable Development for the 21st Century.

The Case of Wyon AG in Switzerland

MARIANTHE STAVRIDOU 



\section{About the Editors}

Philipp Aerni is Director of the Center for Corporate Responsibility and Sustainability (CCRS) at the University of Zurich. He is an interdisciplinary social scientist with a Master's Degree in Geography and a PhD in Agricultural Economics. During his postdoctoral research in public policy, he focused on the role of science, technology, and innovation for sustainable development, with a particular interest in the institutional framework conditions that enable effective public-private partnerships to become drivers of sustainable change. Prior to his position at CCRS, Dr. Aerni worked at Harvard University, ETH Zurich, and the University of Berne, as well as the Food and Agriculture Organisation of the United Nations (FAO). He currently teaches at ETH Zurich, the University of Zurich and the University of Basel. His team at CCRS closely works with partners in academia, government, civil society and business in Switzerland and abroad on practiceoriented and interdisciplinary research projects related to sustainable change in business and society.

Marianthe Stavridou is Head of Business Ethics at CCRS. She studied Linguistics and History at the University of Bern (Switzerland), Sociology and Law in Milan and Rome (Italy) and Corporate Communications and Sustainable Finance at the University of Zurich (Switzerland). Prior to CCRS, she worked in different institutes, think tanks and the private sector. Her research interests include social resilience, migration, entrepreneurship, inclusive growth, SMEs, the SDGs, and business ethics.

Isabelle Schluep is head of the sustainable impact research group at the Center for Corporate Responsibility and Sustainability (CCRS) at the University of Zurich. Her areas of expertise include international trade, public policy, development, food and agriculture. Isabelle conducts interdisciplinary research and develops tools together with industry partners to measure the sustainability performance of companies. 



\section{Contributors}

\section{ALEX GERTSCHEN}

Dr., Center for Global Studies, University of Bern, Bern, Switzerland.

\author{
ALEXANDRU MARCHIS \\ Dr., Università Cattolica del Sacro Cuore \\ (UCSC), Piacenza, Italy.
}

\section{AMANDA NIKLAUS}

Renewable Energy Risk Management Advisory, PEXAPARK, Schlieren, Switzerland.

\section{ANTONIO GAUDIOSO}

Cittadinanzattiva, Rome, Italy.

\section{ARLA JUNTUNEN}

Dr., Independent researcher.

\section{DINO SOZZI}

Dr., No affiliation.

\section{ETTORE CAPRI}

Dr., European Observatory on Sustainable Development (OPERA), UCSC, Piacenza, Italy.

\section{GIANPIERO MENZA}

Dr., Alliance Bioversity International CIAT (CGIAR), Maccarese, Italy.

\section{HENRI RUEFF}

Centre for Development and Environment (CDE) at the University of Bern, Yangon, Myanmar.
ISABELLE SCHLUEP

Center for Corporate Responsibility and Sustainability (CCRS) at the University of Zurich, Zurich, Switzerland.

\section{LIA FERRINI}

University of Basel, Basel, Switzerland.

MARIA ELO

Professor Dr., Department of Marketing and Management, University of Southern Denmark Odense, Denmark; Belt and Road Institute of International Business, School of Economics, Shanghai University, Shanghai, China; Turku School of Economics, University of Turku, Turku, Finland.

\section{MARIANTHE STAVRIDOU}

Center for Corporate Responsibility and Sustainability (CCRS) at the University of Zurich, Zurich, Switzerland.

\section{PHILIPP AERNI}

Dr., Center for Corporate Responsibility and Sustainability (CCRS), University of Zurich, Zurich, Switzerland.

\section{ROMANO DE VIVO}

Center for Corporate Responsibility and Sustainability (CCRS) at the University of Zurich, Zürich, Switzerland.

\section{SUMON VANGCHUAY}

Dr., UN Representative (Geneva, Switzerland), Pan Pacific and Southeast Asia Women's Association (PPSEAWA), Bangkok, Thailand. 



\section{Abstracts}

\section{Preface to Transitioning to Decent Work and Economic Growth by Isabelle Schluep, Philipp Aerni and Marianthe Stavridou}

In the preface of the book on SDG 8, Isabelle Schluep, Philipp Aerni and Marianthe Stavridou introduce the reader to decent work and economic growth by discussing the development of the Sustainable Development Goals in the aftermath of the Millennium Development Goals and the efforts made by the international community to provide the economy with a more equal and inclusive perspective. In the second part of the preface, the authors present the chapters of the book.

\section{Economic Development and Cultural Change: The Role of Multinational Enterprises in Mexico's Emerging Dual Economy (1970s to 2000s) by Alex Gertschen}

This article focuses on multinational enterprises (MNEs) in Mexico between the 1970s and the 2000s. From a business and economic history perspective, it depicts the MNEs' transformation in the context of Mexico's integration into global value chains (GVCs) from sceptically viewed outsiders to engines of economic development and normative role models. This transformation resulted from an interplay between economic cooperation and cultural change. The idea of embeddedness and reconstructed business discourses on enterprises' social responsibility and on total quality management serves to grasp this interplay conceptually and methodically, respectively. In fact, when local businesses established or intensified collaboration with foreign MNE subsidiaries, they engaged in the joint promotion of cognitive and normative ideas about the challenges of the global market, and how they could be met. Notably, they promoted the idea that competitiveness in GVCs allowed for or even required social responsibility. Indeed, this 'globalised Mexico' consisting of MNEs and their often big local partners is an example that economic growth and social standards can be simultaneously reached, as postulated by Sustainable Development Goal (SDG) 8. However, this is not the reality of most micro, smalland medium-sized companies that constitute the majority of business, the other part of Mexico's dual economy. Therefore, the article also demonstrates that the 'virtuous cycle' of economic performance and social responsibility is historically contingent, and that it can work, but not necessarily and not for all. 


\section{Challenges for the Host Society-Human Trafficking, Slavery and Abuse in the Work Context by Maria Elo and Arla Juntunen}

The mobile labor force benefits host societies with diverse forms of human capital. The economic value and potential of people migrating for work offer incentives for the development of illicit and abusive practices that employ the vulnerability of the migrants and an institutional lack of attention or experience. This may happen regardless of the skill-level of the migrants, but particularly migrants who are new, inexperienced, and low-skilled may be targeted by actors who wish to exploit their state. These mechanisms may already start during recruitment in the home country by transnational criminal networks, but they also emerge organically in the host country if there are available activity-scapes for such practices. This phenomenon of human trafficking, slavery, and abuse related to work entered Finland in recent decades. The actors involved are often of foreign-origin or within ethnic enclaves, which also creates cultural- and languagerelated institutional divides. We found that a host country that is highly developed may not have the needed institutional experience, understanding, or attention to effectively combat the phenomenon. We suggest that preventive governance with more targeted collaboration across governance, diaspora organizations, and civil society could reduce illicit opportunities and increase awareness of what is appropriate and acceptable, i.e., decent work.

\section{"Business as Part of the Solution": SDG 8 Challenges Popular Views in the Global Sustainability Discourse by Philipp Aerni}

Sustainable Development Goal 8 (SDG 8) aims to make the global economy more inclusive by directing its attention to the many unmet material needs of the poor on this planet. SDG 8 also recognizes the need to decouple economic growth from the unsustainable use of natural resources. Tackling these challenges effectively requires action-oriented public-private partnerships and the mobilization of innovative entrepreneurship for sustainable and inclusive change. However, this approach is contested in the current global discourse on sustainable development in affluent societies, which is more concerned about the negative impact of economic growth. This concern is also omnipresent in the teaching material used in 'Education for Sustainable Development' (ESD). It is often strictly normative 
in nature and frames the pursuit of growth-oriented business activities as being opposed to sustainable lifestyles. This chapter challenges this view by looking at business not just as an external black box, but as an integral part of society. In this context, concrete examples are presented to illustrate how sustainability challenges have been addressed effectively in society by making 'business part of the solution'. Since SDG 8 stands for such an approach, it could lead the way from the rhetoric to action in the decade that remains to meet Agenda 2030.

\section{Memories of a Practitioner: \\ Ciba-Geigy Crop Protection Activities in Indonesia in the 1980s, an Example of Local Embeddedness by Dino Sozzi}

After the end of World War II, an international initiative was launched by the US government to respond to the looming food crisis in the Global South, through large-scale public sector investments towards the improvement of the productivity of the world's major staple crops. Ciba-Geigy Agrochemicals and Ciba-Pilatus Aerial Spraying Co. were, at the time, strongly involved in the process through the delivery of large quantities of crop protection products under government contracts. This was also the case in Indonesia where the author worked for CibaGeigy in the 1980s. Looking back, he finds that Ciba-Geigy only started to focus on the farmer as the main client in a comprehensive way when the government of Indonesia withdrew from its function as a provider of subsidized agrochemical input to farmers. Once the farmer rather than the government became the main client, Ciba-Geigy started to create many direct and indirect benefits for local farmer communities through capacity development programs that included the transfer of soft skills, more sustainable and productive agricultural practices, and business development skills. This commitment to local embeddedness also contributed to higher local average incomes, more jobs, better schooling for kids and improved public health conditions. This change of behavior is illustrated by concrete initiatives developed and implemented by Ciba-Geigy and its legacy companies. Pointing out that business can also be part of the solution, UN SDG 8 introduced a more solution-oriented view of sustainable development that may gather momentum in future policy approaches to achieve Agenda 2030 and new ways of teaching sustainable development. 


\section{Multilevel Sustainability Tensions of MNEs in Developing Countries by Lia Ferrini}

Translating the global Sustainable Development Goals (SDGs) into the local context can be a challenging pathway. Promoting inclusive and sustainable economic growth', as advocated by SDG 8, can be fostered or hindered by relevant economic actors depending on global and local framing conditions. This is the case for subsidiaries of multinational enterprises (MNEs) operating in developing countries, which are confronted by highly regulated international standards and weaker local institutional settings. The global-local tension is complicated by the growing trend of MNEs to adopt their own Corporate Social Responsibility (CSR) guidelines. Ethical tensions faced by MNEs are not new in the literature; there is, however, limited knowledge on how a company's guidelines are conceived in the global-local relationship. Additionally, the literature on CSR has been dominated by a win-win perspective, neglecting trade-offs inherent in the multifaceted nature of sustainable development. The following literature review aims to address the abovementioned knowledge gap, by exploring literature on tensions occurring between global ethical standards, local contexts and CSR guidelines faced by MNEs operating in developing countries, with a perspective on tensions happening in and between the three levels. The review is positioned in the international business ethics literature and brings together two distinguished debates on 'business ethics and culture' and 'trade-offs in CSR'. By investigating current discourses in the literature addressing multilevel tensions faced by MNEs, this chapter highlights research gaps and proposes new avenues of research. Additionally, five criteria are developed to guide the identification of relevant theoretical frameworks for empirical explorations of multilevel sustainability tensions faced by MNEs.

\section{Agriculture in the Face of Climate Change: \\ Sustained and Inclusive Economic Growth as a Prerequisite for Sustainable Development \\ by Romano De Vivo, Ettore Capri, Henri Rueff, Antonio Gaudioso, Alexandru Marchis, and Gianpiero Menza}

Climate change and weather extremes are already impacting millions of people, devastating crops, eroding coastlines, and threatening freshwater reserves. 
The agricultural sector is extremely vulnerable to the potential threats of climate change and must be prepared to mitigate and adapt. Decisive measures could help agriculture face expected changes, help keep global temperatures in check and also serve and create synergies between climate and sustainable development goals. Climate-smart agriculture - with its three objectives: sustainable increases in agricultural productivity and income, greater resilience of food systems, and the reduction of greenhouse gas (GHG) emissions associated with farming - may represent a model to best help direct our actions. Addressing the socio-economic and environmental challenges related to climate change requires a concerted effort from all actors and locally adapted responses to ensure we move towards sustained and inclusive economic growth (SDG 8). Businesses have already started to act and need to be supported in their efforts by a system of policies and an enabling environment for multistakeholder collaborations.

\section{Employment Gender Gap in the Renewable Energy Sector by Sumon Vangchuay and Amanda Niklaus}

Renewable energy is seen as avant-garde and a pathway towards a more sustainable future. This modern and growing sector is often perceived as progressive and conducive to a more democratic and inclusive society. In the context of the SDG 8, our paper sets out to examine this claim and to assess opportunities for gender inclusion and equality in the renewable energy workforce. We examine the rationale for equity and inclusion under SDG 8 and evaluate how gender is reflected in its targets and indicators, as well as how they are related to SDG 5 and SDG 7. We then employ mixed methods research to examine the gender gap in the renewable energy workforce and discuss specific challenges and good practices in the sector. We found that the socio-economic progress deriving from renewable energy does not necessarily extend to gender diversity in its workforce. We argue that gender diversity can be compatible with economic growth when the benefits of economic growth and those of gender parity are mutually reinforcing. Inclusive growth in the renewable energy transition is possible when women are empowered to participate fully, effectively and competitively in their career. 


\section{"Me muess d'Lüt neh wie si sy-Anderi gits e keini". Decent Work and Sustainable Development for the 21st Century: The Case of Wyon AG in Switzerland by Marianthe Stavridou}

Small and Medium Enterprises (SMEs) in Switzerland are the backbone of the Swiss economy and account for $2 / 3$ of employers in the country. This paper examines decent work and sustainable economic growth as promoted by the United Nations Sustainable Development Goal 8. The author focuses on Small and Medium Enterprises and discusses business ethics and human-centred values as drivers of inclusive change. We argue that Swiss Small and Medium Enterprises (SMEs), in many cases, create a new paradigm of doing business, relying on tradition, innovation and a focus on essential human values. Traditional communitarian values, a vision for innovation, democratic flat decision-making structures and transparency, as well as financial independence, are crucial elements of the SMEstrategy, offering decent work and a sustainable long-term prosperity. As an example of a Swiss SME, we examine Wyon AG a small high-end technology firm in the village of Steinegg, District of Rüte, in the Canton Appenzell Innerrhoden. This is a desk research. 



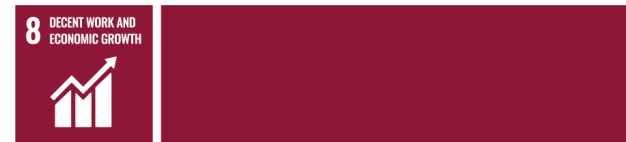

\title{
Preface to Transitioning to Decent Work and Economic Growth
}

\author{
Isabelle Schluep, Philipp Aerni and Marianthe Stavridou
}

\section{Introduction}

We live in unprecedented times. Five years after the launch of the United Nations Sustainable Development Goals (UN SDGs) in 2015, and one year after the first lockdown due to the COVID-19 pandemic in 2020, the global effort to build a more equal, inclusive and sustainable society will likely experience a serious setback.

The desire to create a more inclusive and sustainable global economy proved to be one of the few common denominators in the design and launch of the SDGs. The emphasis on the creation of economic opportunities to address global sustainability challenges also implied that business should play a prominent role in the implementation of the SDGs. This view amounted to a major paradigm shift in the way we think about sustainability. The Millennium Development Goals (MDGs), which were launched by the UN in 2000 to reduce poverty by half in 2015 (UN 2000), did not regard private sector involvement as highly relevant. Regarding environmental sustainability, the aim of the SDGs to create a green economy also implies that regulation alone will not be able to save the planet; instead, it requires the courage to invest in innovative solutions that effectively address environmental challenges, while creating new jobs for the next generation. This progressive understanding of sustainability is clearly articulated in the Agenda for Sustainable Development (2030 Agenda), designed to implement the 17 SDGs with its 169 targets. The 2030 Agenda calls on governments, civil society, and, most importantly, the private sector to join forces in realizing this plan of action for the people, planet and prosperity (UN 2015). It is based on the basic insight that business is a part of society-not apart from society.

SDG 8 very much embodies this paradigm shift. It aims to "promote sustained, inclusive and sustainable economic growth, full and productive employment and decent work for all". Its emphasis is on the creation of business opportunities that especially benefit the local people and the environment. It is also linked to the importance of institutional and technological innovations designed to enable this transition. As such, SDG 8 is connected with many other goals, such as the elimination of poverty (SDG 1) and hunger (SDG 2), the promotion of access to quality 
education (SDG 4) and improved infrastructure (SDG 9), the reduction in global inequality (SDG 10), the promotion of responsible consumption and production (SDG 12), and capacity development and access to markets (SDG 17). Its emphasis on economic empowerment has also an important link to gender equality (SDG 5).

Finally, SDG 8 is key to every person's life. "Decent work is at the heart of the search for dignity for the individual, stability for the family and peace in the community" as put by Juan Somavía, former Director-General of the International Labor Organization (ILO). In addition, SDG 8 stands for the catalytic linkages and spillovers between employment and development. After all, labor income contributes considerably to the reduction of poverty (Azevedo et al. 2013); and more and better quality jobs are the surest pathway to achieve social inclusion, to end poverty and boost prosperity (IFC 2013).

Even before the COVID-19 pandemic disrupted the world economy, the jobs challenge has been enormous; it was calculated that, between 2016 and 2030, 30 million jobs would be required per year just to keep pace with the increasing global working age population (UN 2018). COVID-19 caused the worst global recession since the Great Depression in the 1930s (Gopinath 2021), and resulted in the loss of 255 million full-time jobs, which is about four times more than over the course of the global financial crisis in 2009 (ILO 2021). The International Monetary Fund (IMF) expects that, in 2021, more than 150 economies will have per-capita incomes below 2019 levels, and that workers with little education, youth, women and persons employed in the informal sector will be disproportionately affected by the expected losses of income (IMF 2021; Gopinath 2021). As a consequence, the IMF projects that close to 90 million persons could fall into extreme poverty over the course of 2020-2021, which could reverse many of the social achievements of the past 20 years (Gopinath 2021; IMF 2021). In reaction to this crisis, the United Nations have released a socio-economic response framework (UN 2020).

UN Secretary General António Guterres rightly argued that "Everything we do during and after the COVID-19 crisis must be with a strong focus on building more equal, inclusive and sustainable economies and societies that are more resilient in the face of pandemics, climate change and the many other global challenges we face" (The Lancet 2020). This quote represents the core of SDG 8 on the creation of inclusive growth and decent work, it very much addresses the concerns of the majority world, the people who live in low-income countries. Since more than 90 percent of jobs in developing countries are created by the private sector (IFC 2013), more attention must be paid to entrepreneurs that help create dynamic, growth-oriented, innovative and responsible enterprises. To succeed in the long-run, entrepreneurs need to gain 
trust as responsible business partners and create value for society. As such, they not only propel their own business, but also enable other people to get out of poverty through the enhancement of local economic opportunities.

In high-income countries, the fear that the fourth industrial revolution could render many jobs obsolete is real. In response to this concern, the policy focus in many of these countries has shifted from a defensive attitude toward sustainable development, which is mainly concerned with preserving economic structures and preventing unsustainable change through regulation, toward a more forward-looking attitude, which is more focused on creating new sustainable markets through innovative entrepreneurship. In this context, the volume "Transitioning to Decent Work and Economic Growth" may be a valuable guide for policy makers aiming to move towards a more progressive understanding of sustainable development.

\section{Chapters in the Volume}

The contributions in this volume may only cover a fraction of the breadth of SDG 8, but they outline the major opportunities and challenges of the efforts to implement SDG 8 from different perspectives. Generally, there is a consensus among the authors that SDG 8 is also highly relevant in the effective implementation of many other SDGs, and that institutional framework conditions are of crucial importance to enable inclusive and sustainable change by making "business part of the solution". This volume aims to approach decent work and economic growth under different perspectives. Each chapter highlights a diverse set of issues.

From a business and economic history perspective, Alex Gertschen discusses multinational enterprises' (MNEs) local embeddedness in Mexico during the period from the early 1970s to the 2000s. Analysing the interplay of economic cooperation and cultural change, he reconstructs MNEs' transformation from sceptically viewed outsiders to engines of economic development and normative role models. Together with local business, they promoted the idea that competitiveness in global value chains allowed for or even required social responsibility. The author concludes that MNEs' embeddedness in Mexico indeed serves as an example that economic performance and social standards can be reached simultaneously, as postulated by SDG 8. However, this "virtuous cycle" may work only under certain circumstances and not for all. This qualification is suggested by the fact that it is largely confined to the globalized part of Mexico's economy.

For Maria Elo and Arla Juntunen, preventive governance and targeted collaboration with diaspora organisations and the civil society are needed to reduce the phenomena of exploitation, slavery, human trafficking and abuse in 
a developed country like Finland and help the country safeguard decent work principles. The case study on Finland presents illicit and abusive practices related to migration, which develop partly due to an institutional lack of attention and experience. Human trafficking, slavery and abuse may start in the migrant's home countries during the recruitment of the workforce by transnational criminal networks; however, they represent a recent and unperceived phenomenon in the host country with fundamental socioeconomic implications. The actors of such networks are mostly people of foreign-origin or people within ethnic enclaves in Finland. This indicates the existence of cultural- and language-related institutional divides. The authors suggest investing in targeted collaboration among the main stakeholders to increase awareness about decent work, close loopholes, and prevent illicit practices early on, before they start mushrooming.

Philipp Aerni challenges mainstream economic thinking on sustainable development in high-income countries, which tends to ignore the potential positive externalities created through scalable innovation for society and the environment. It fails to understand that poverty is still the main enemy of sustainability in many low-income countries. He argues that tackling the unmet material needs of the poor, promoting inclusive economic change and enabling innovation that helps to decouple economic growth from natural resource use would require action-oriented public-private partnerships and institutional framework conditions that better award innovative entrepreneurship for sustainable and inclusive change. He also proposes an understanding of businesses as an integral part of society and not just an external black box. In this context, he presented concrete international and national initiatives that were proven to contribute to sustainable and inclusive change. Finally, Aerni is concerned that most of the teaching material used in "Education for Sustainable development" (ESD) tends to ignore examples, which prove that businesses can be part of the solution.

Dino Sozzi was a practitioner at Ciba-Geigy company in the 1980s in Indonesia, when the indebted Indonesian government was forced to stop buying agrochemicals in bulk from the company in order to subsequently resell it at a subsidized price to farmers. He describes how this agricultural reform forced the company to focus its attention directly on the farmers, and how they apply their products. The company realized that it is in its very long-term self-interest to encourage their farming clients to apply their input in a more sustainable, safe and effective way. It did so by creating local capacity-building programs that helped farmers to better manage their resources. Thus, the commercial activities of Ciba-Geigy crop protection, and eventually its legacy company Syngenta, became more embedded in the local 
economy, which also increased the appreciation of the local farming communities. The new corporate commitment to supporting local farmers in improving their agricultural practices changed the landscape of income, education and employment for the local communities as a whole. This is the turning point at which Sozzi believes that his company started to make a genuine contribution to a more inclusive local economy.

Lia Ferrini discusses the literature gap in corporate social responsibility (CSR) research regarding the ethical tensions faced by subsidiaries of MNEs operating in developing countries when they have to navigate between global ethical standards, local contexts and CSR guidelines. Her review brings together two distinguished debates on "business ethics and culture" and "trade-offs in CSR", and highlights research gaps proposing new advances in research.

Romano De Vivo, Ettore Capri, Henri Rueff, Antonio Gaudioso, Alexandru Marchis and Gianpiero Menza explore climate change mitigation and adaptation options for agriculture, the world's largest employer and provider of livelihoods for 40 percent of the global population. They present Climate-Smart Agriculture (CSA) as a model that can best help to guide transformative actions in the agri-food sector to increase productivity and resilience and to reduce greenhouse gas emissions in a sustainable way. The CSA's "action path" for sustainable and inclusive economic growth includes policies that enable multi-stakeholder collaboration, and are implemented by organizations that have integrated sustainability into their business models.

Sumon Vangchuay and Amanda Niklaus examine the gender gap in the workforce of the renewable energy sector, a young and fast-growing sector often perceived as progressive by the public at large. The authors discuss this issue at two levels: framework and practice, and argue that the socio-economic progress to be made in the renewable energy sector under the SDGs does not necessarily extend to gender diversity in the workforce. They conclude, that a widespread gender gap in the renewable energy workforce casts serious doubts about the inclusive growth and progress made in the energy transition under the SDGs. Vangchuay and Niklaus highlight the need to align economic growth with inclusion, and recommend that significant, targeted efforts be put in place to challenge the traditional gender perspectives and guarantee a sustainable change within this sector.

The last chapter by Marianthe Stavridou focuses on the contribution of a high-end technology Small and Medium Enterprise (SME) in Switzerland to inclusive and sustainable change. She shows how innovative entrepreneurship is guided by a vision to create long-term prosperity among the workforce by taking a human-centred 
approach to business. The author challenges the existing concept of decent work, in which economic growth is still understood in its crude measurement as the growth in gross domestic product (GDP). Instead, she proposes a 21st century narrative of decent work that is based on a more holistic understanding of economic development.

\section{Conclusions}

This Volume pulls together analyses and experiences from the past and present, from large and small companies, from the Global South and North, and from different sectors. Many contributions point out that entrepreneurship and innovation are important drivers of inclusive and sustainable change. In this context, there is a general agreement that business can be part of the solution in efforts to realize the 2030 Agenda in general, and SDG 8 in particular.

\section{References}

Azevedo, Joao Pedro, Gabriela Inchauste, Sergio Olivieri, Jaime Saavedra, and Hernan Winkler. 2013. Is Labor Income Responsible for Poverty Reduction? A Decomposition Approach. World Bank Policy Research Working Paper No. 6414. Washington, DC: World Bank.

Gopinath, Gita. 2021. A Race Between Vaccines and the Virus as Recoveries Diverge. IMF Blog from 26 January 2021. Available online: https://blogs.imf.org/2021/01/26/a-race-betweenvaccines-and-the-virus-as-recoveries-diverge/ (accessed on 8 March 2021).

International Finance Corporation. 2013. IFC Jobs Study: Assessing Private Sector Contributions to Job Creation and Poverty Reduction. Washington, DC: International Finance Corporation, Available online: https://openknowledge.worldbank.org/handle/10986/16979 (accessed on 24 February 2021).

International Labour Organization. 2021. ILO Monitor: COVID-19 and the World of Work. Seventh Edition. Available online: https://www.ilo.org/wcmsp5/groups/ public/---dgreports/---dcomm/documents/briefingnote/wcms_767028.pdf (accessed on 22 February 2021).

International Monetary Fund. 2021. World Economic Outlook Update. January 2021. Available online: https://www.imf.org/en/Publications/WEO/Issues/2021/01/26/2021world-economic-outlook-update (accessed on 8 March 2021).

The Lancet Public Health. 2020. Will the COVID-19 Pandemic threaten the SDGs? The Lancet Public Health 5: e460. [CrossRef]

United Nations. 2020. COVID-19 response. Sustainable Development Goals. Available online: https://www.un.org/sustainabledevelopment/economic-growth/ (accessed on 8 March 2021). 
United Nations. 2018. Decent Work and Economic Growth: Why It Matters. Available online: https://www.un.org/sustainabledevelopment/wp-content/uploads/2016/08/8_ Why-It-Matters-2020.pdf (accessed on 25 March 2021).

United Nations. 2015. Transforming our world: the 2030 Agenda for Sustainable Development. General Assembly Resolution 70/1 adopted by the General Assembly on 25 September 2015. Available online: https://www.un.org/ga/search/view_doc.asp?symbol=A/RES/70/ 1\&Lang=E (accessed on 8 March 2021).

United Nations. 2000. United Nations Millennium Declaration. General Assembly Resolution 55/2. Available online: https://www.refworld.org/docid/3b00f4ea3.html (accessed on 6 March 2021).

(C) 2021 by the authors. Licensee MDPI, Basel, Switzerland. This article is an open access article distributed under the terms and conditions of the Creative Commons Attribution (CC BY) license (http://creativecommons.org/licenses/by/4.0/). 



\section{Economic Development and Cultural Change: The Role of Multinational Enterprises in Mexico's Emerging Dual Economy (1970s to 2000s)}

\section{Alex Gertschen}

\section{Introduction}

Sustainable Development Goal (SDG) 8 calls for the promotion of "sustained, inclusive and sustainable economic growth, full and productive employment and decent work for all". In the context of this Special Issue, which emphasises the private sector's role in achieving SDG 8, this article focuses on multinational enterprises (MNEs) in Mexico. MNEs can be defined as enterprises that engage in foreign direct investment and own or control value-added activities in more than one country (Dunning and Lundan 2008, p. 3). Historians, economic, political, and social scientists consider Mexico an important example of a country that radically shifted the main responsibility of economic development from government to private business. During the 1980s, in the midst of an economic and financial crisis, state intervention was drastically reduced by liberalising markets, privatising state-owned companies, and cutting industrial policies. MNEs were given a crucial role, as they were supposed to bring capital and know-how to Mexico, boosting competitiveness and employment in the context of world market integration (Dussel Peters 2000; Moreno-Brid and Ros 2009; O'Toole 2010; Urquidi 2005; Schneider 2009).

From an SDG 8 perspective, the overall results of this "business-led"1 economic development are rather disappointing (Carrillo et al. 2012b; Dussel Peters 2003; Moreno-Brid and Ros 2009; Viñuales and Langer 2012). Despite a soaring number of manufactured exports, the average GDP growth per capita was only $1.5 \%$ between 1990 and 2005, and has not considerably accelerated since then (see Figures 1 and 2).

1 Schneider 2009 argues that since the 1980s, due to the dominance of a small number of domestic and foreign corporations, development in Mexico and other Latin American countries has been neither state- nor market-led. 


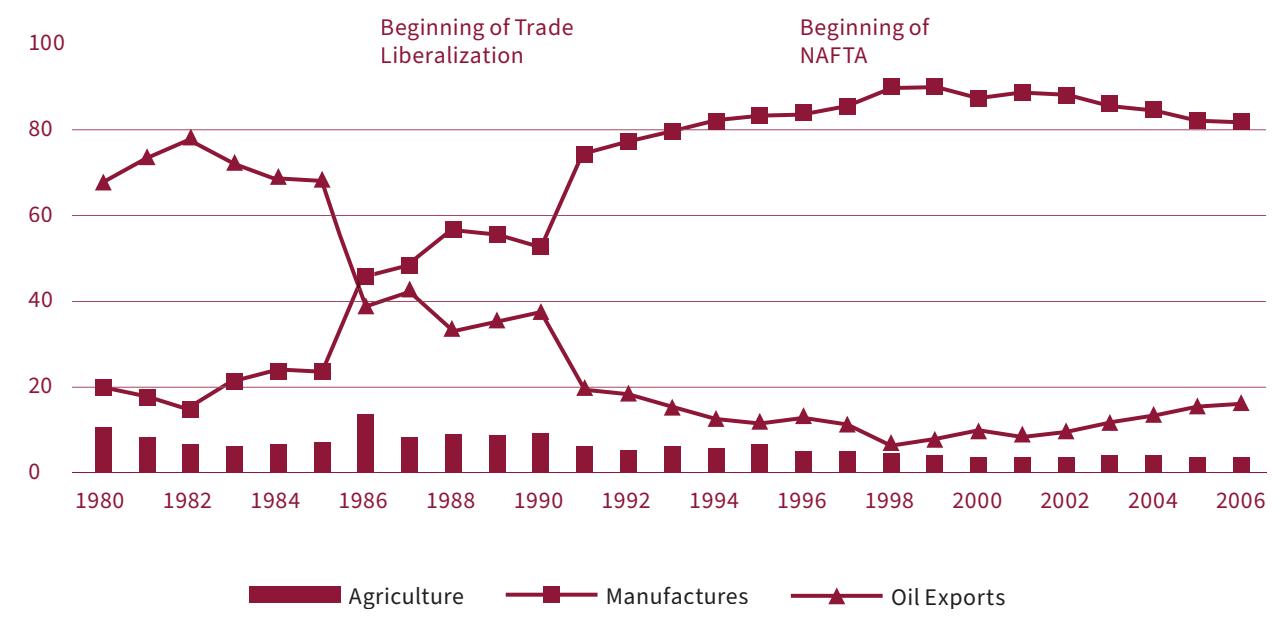

Figure 1. Composition of total exports, Mexico 1980-2006 (\%). Source: (Moreno-Brid et al. 2009, p. 160).

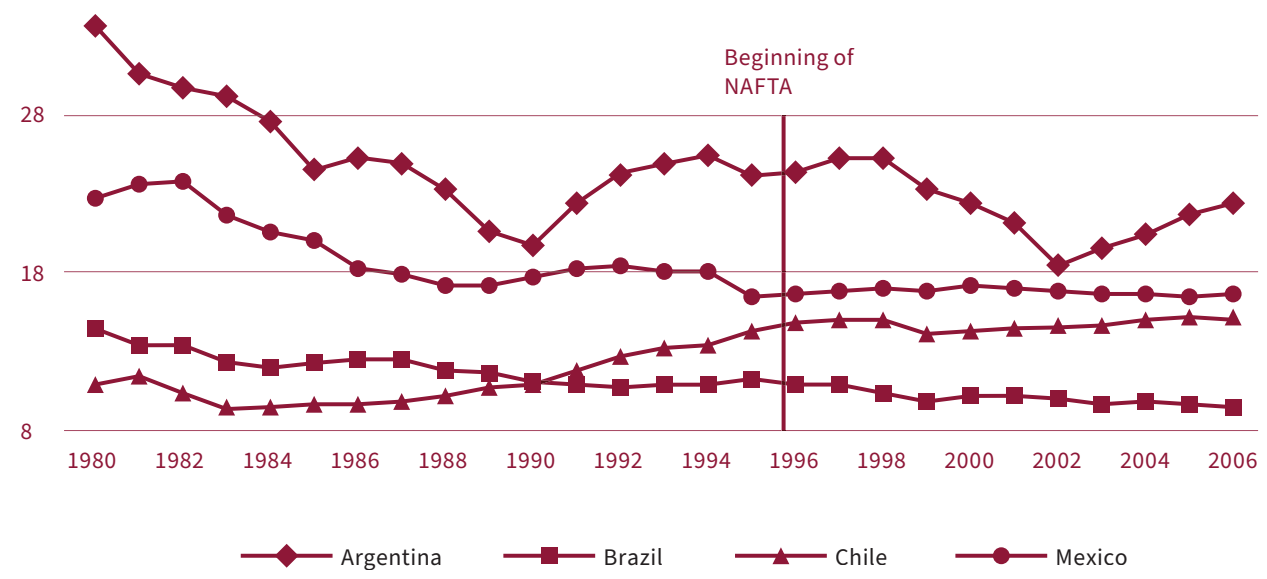

Figure 2. Mexico and other countries: real GDP per capita (relative to the USA) 1980-2006 (USA GDP per capita = 100, measured in constant 2000 US\$) Source: (Moreno-Brid et al. 2009, p. 162). 
The GDP growth per capita has proved insufficient to provide for enough employment, let alone decent work. The informal sector, with its precarious working conditions, keeps growing. ${ }^{2}$ However, these figures conceal important differences within Mexico's economy. For instance, the automotive, electronics, and aerospace industries have flourished and largely realised what liberal reforms had promised: dominated by mainly foreign MNEs, ${ }^{3}$ they have grown in output and productivity, created jobs with relatively good working conditions for middle- and high-skilled personnel, and have integrated Mexico into global value chains (GVCs). ${ }^{4}$ Thanks to its manufacturing exports, Mexico has reduced its vulnerability to commodity prices, which makes it a positive exception in Latin America (OECD 2009, pp. 68-73, and Cadestin et al. 2016, p. 192). This "globalised Mexico" contrasts starkly with the one described above, which is further characterised by domestic market orientation and the prevalence of micro, small- and medium-sized enterprises (MSME) (see Table 1 for a statistical comparison). Therefore, many authors speak of a "dual economy" (Moreno-Brid and Ros 2009, p. 187; Pozas 2006, p. 78; Villavicencio 2012, p. 37). ${ }^{5}$

This article provides an analysis of the emergence of this dual economy in the context of globalisation from the 1970s to the 2000s. From a business and economic history perspective, it depicts MNEs' transformation from sceptically viewed outsiders to the economic engines and normative role models of globalising Mexico. The concept of embeddedness helps analytically grasp this transformation. In line with a business and economic history after the cultural turn, (Berghoff and Vogel 2004), it emphasises the manifold contingencies of economic activity-cognitive, normative, institutional, and therefore cultural in the widest sense (Dequech 2003, pp. 461-70). Like in any other realm of the social world, in the economy, actors' interests and the ways in which they pursue them can be better understood and explained if connected to the underlying cognitive and normative ideas, and the formal and informal rules that characterise a cultural collective. ${ }^{6}$

2 For historical figures, see (Moreno-Brid and Ros 2009, pp. 261-78; Ros 2008, p. 538). For more recent development see (OECD 2019).

3 On the emergence of Mexico-based MNEs, see: (Andonova and Mauricio 2018; Hoshino 2013; Lessard and Lucea 2009; Pozas 2002; Santiso 2013).

4 For working conditions in MNEs, see: (Bensusán et al. 2018; Bensusán and Carrillo 2017; Carrillo et al. $2012 b)$. For an analysis of MNEs' structural importance in Mexico, see (Schneider 2009).

5 For the description of the same phenomenon, Schneider (2009) coined the term hierarchical market economy.

6 For a critical analysis of this approach, see (Schmid 2008, pp. 73-103). For my own understanding of the cultural contingency of economic activity, see (Gertschen 2013, pp. 37-43). 
Table 1. Measuring employment in Mexico's "dual economy".

\begin{tabular}{|c|c|c|c|c|c|c|}
\hline & \multicolumn{2}{|c|}{$\begin{array}{l}\text { Foreign MNE } \\
\text { Subsidiaries }\end{array}$} & \multicolumn{2}{|c|}{ Mexican MNEs } & \multicolumn{2}{|c|}{ Non-MNEs } \\
\hline & 2009 & 2014 & 2009 & 2014 & 2009 & 2014 \\
\hline \multicolumn{7}{|c|}{ People employed } \\
\hline & 889,044 & 921,878 & 45,057 & 31,433 & $3,726,961$ & $4,120,121$ \\
\hline Comment by the authors & \multicolumn{6}{|c|}{$\begin{array}{l}\text { Informal hiring is, in MNEs, three times lower than in } \\
\text { non-MNEs, and there is a greater tendency towards the } \\
\text { formalisation of employment with MNEs. }\end{array}$} \\
\hline \multicolumn{7}{|c|}{ Union Membership of employees (in \%; no distinction between Foreign and Mexican MNEs) } \\
\hline Yes & 25 & 25 & 25 & 25 & 11 & 10 \\
\hline No & 73 & 73 & 73 & 73 & 87 & 89 \\
\hline Do not know & 2 & 2 & 2 & 2 & 2 & 2 \\
\hline \multicolumn{7}{|c|}{ Working hours per week (in \%) } \\
\hline $0-14$ & 0 & 0 & 0 & 0 & 0.6 & 0.7 \\
\hline $15-24$ & 0.3 & 0.8 & 0 & 0 & 1.7 & 2.4 \\
\hline $25-34$ & 2.2 & 3.9 & 0.4 & 2.3 & 3 & 4.9 \\
\hline $35-39$ & 4.9 & 8.3 & 3.3 & 1.5 & 4.1 & 5.4 \\
\hline $40-48$ & 58.6 & 61.6 & 84.1 & 53.6 & 62.7 & 52.5 \\
\hline $49-56$ & 28.1 & 17 & 11 & 21.2 & 16.5 & 17.1 \\
\hline \multirow[t]{2}{*}{ More } & 5.9 & 8.4 & 1.2 & 21.4 & 11.4 & 17 \\
\hline & 100 & 100 & 100 & 100 & 100 & 100 \\
\hline
\end{tabular}

Incomes (per month, in Mexican Pesos)

\begin{tabular}{|c|c|c|c|c|c|c|}
\hline $\begin{array}{l}\text { Average of salaried workers directly } \\
\text { linked to production, sales, or } \\
\text { providing services }\end{array}$ & 7109 & 7847 & 7803 & 9649 & 5179 & 6559 \\
\hline $\begin{array}{l}\text { Average of administrative, accounting } \\
\text { and management employees }\end{array}$ & 19,418 & 22,091 & 21,752 & 20,433 & 13,971 & 15,803 \\
\hline $\begin{array}{l}\text { Average of company's contribution to } \\
\text { social security }\end{array}$ & 1360 & 1704 & 1454 & 2475 & 929 & 1149 \\
\hline Average of other social benefits & 1015 & 1327 & 1306 & 1085 & 646 & 1040 \\
\hline $\begin{array}{l}\text { Average of profits distributed to } \\
\text { workers (annual) }\end{array}$ & 5229 & 7814 & 3500 & 12,114 & 3270 & 4899 \\
\hline Comment by the authors & \multicolumn{6}{|c|}{$\begin{array}{l}\text { Wage tendency is decreasing in MNEs and non-MNEs; } \\
\text { particularly backward in the administrative staff that work in } \\
\text { Mexican MNEs. }\end{array}$} \\
\hline
\end{tabular}

MNEs: multinational enterprises. Source: Author; data from (Bensusán and Carrillo 2017; Bensusán et al. 2018). 
In this vein, Mexico's dual economy and globalisation are considered economic and cultural phenomena. There is empirical evidence for a positive correlation between economic development and MNE subsidiaries' integration. Local supplier or provider relationships, collaborations with education and research institutions, or initiatives to foment local competitiveness have allowed for an industrial upgrading of both the subsidiaries' activities and the socio-economic environment in Mexico (Carrillo et al. 2012a, 2012b). The concept of embeddedness suggests that such economic processes occur in an interplay with cultural change, which in turn refers to a notion of sustainable development that goes beyond the improvement of efficiency and consistency in natural resources management and encapsulates a cultural transformation (Schneidewind 2018). Therefore, this article follows two lines of argument: MNEs' enhanced economic and normative relevance was bound to cooperation with local actors; and this cooperation required a cognitive and normative understanding, as well as rules that made actors' behaviour reliable and legitimate. The study does not aim to generate insights on SDG 8 per se, but on historical changes that brought the globalised and MNE-led part of Mexico's economy closer to achieving this goal than the majority of the country's businesses.

\section{Materials and Methods}

In order to depict and analyse the interplay of economic and cultural change, which led to the globalised part of Mexico's dual economy, we reconstruct business people's discourses on enterprises' social responsibility (CSR) and total quality management (TQM). CSR discourse, which emerged in Mexico in the 1960s (Gertschen 2017), helps us to understand business people's perceptions of the social context, of their legitimacy vis-à-vis society, as well as their interest and efforts to establish trustful relationships with employees and other local stakeholders. Legitimacy and trust surge from shared cognitive and normative ideas, and institutions. They are considered indispensable for a company's licence to operate in a specific society (Gertschen 2017, pp. 528-30). ${ }^{7}$ TQM spread rapidly and globally during the 1980s and particularly the 1990s. According to it, human beings are the main source of errors, and eliminating these errors is possible if companies enhance control of processes and products by statistical means on the one side and workers' involvement on the other. By emphasising the "human factor", TQM advanced the idea that

7 For sociological contributions to these terms and their interrelatedness, see Maurer and Schimank 2008. For an important contribution by business history, see (Berghoff 2004). 
culture has a decisive impact on cooperation within and outside the company, and on competitiveness (Laboucheix 1992; Wilkinson and Willmott 1995). ${ }^{8}$ Neither CSR nor TQM discourses signify actual change towards decent work and other aspects of SDG 8. Used heuristically, they serve to reconstruct the (cultural) change of business people's cognitive and normative ideas, and concomitant rules of cooperation, which enabled MNEs' increasing embeddedness in Mexico.

For the reconstruction of the two discourses, written and oral statements of both domestic business people and MNE representatives were considered. ${ }^{9}$ This allowed for distinguishing between the local context and MNEs, even though domestic business people represent only an (important) fraction of this context. The statements were gathered with a qualitative mixed-methods approach (Diekmann 2014). The main sources are documents of the Mexican Centre for Philanthropy (Centro Mexicano para la Filantropía, CEMEFI), the Social Union of Mexican Businessmen (Unión Social de Empresarios de México, USEM), and the Mexican Total Quality Foundation (Fundación Mexicana para la Calidad Total, FMCT). ${ }^{10}$ They played crucial roles in CSR and TQM discourses, produced a considerable amount of publications, and connected domestic business and MNEs in terms of ideas and people. The latter holds particularly true for the CEMEFI and FMCT, which collaborated closely with foreign MNE subsidiaries. In order to better reconstruct the MNE perspective, documents from the U.S. American Chamber of Commerce in Mexico (Amcham), the Switzerland-based MNEs Nestlé and Ciba-Geigy (as of 1996, Novartis), and their respective subsidiaries Compañía de Nestlé S.A. (CONESA) and Ciba-Geigy Mexicana (CIGEMEX) were considered. ${ }^{11}$ Because written statements regarding the two subsidiaries and the 1990s (due to archival restrictions)

8 For an assessment of TQM in a historical perspective of management thought, see (Bonazzi 2014, ch. 7; Witzel 2012, ch. 10).

9 Methodologically, we focused on people with executive responsibility on the company or sectorial level (such as members of an executive committee, board of directors, or representatives of business associations), and on two different kinds of statements: public statements to foster corporate legitimacy and trustworthiness with society, and internal statements referring to this business discourse.

10 The CEMEFI operates in Mexico City; a library with archival material (henceforth indicated as CEMEFI). The national Confederación USEM, also headquartered in Mexico City, has neither an archive nor a library. However, on eight occasions between 2014 and 2017, the author was allowed to access then General Director Germán Araujo's personal library (henceforth Conf. USEM). The FMCT does not exist anymore. Its publications were retrieved from public libraries in Mexico City or provided by José Giral, former FMCT president, whom the author interviewed in Mexico City on 11 April 2016.

11 Amcham documents are all publications and therefore publicly accessible. Some documents on Nestlé, CONESA, Ciba-Geigy, and CIGEMEX stem from the respective company archive Archives historiques Nestlé (henceforth AHN) and Firmenarchiv der Novartis AG (henceforth FAN). 
are scarce, on an Oral History basis (Obertreis 2012), semi-structured interviews with two former chief executives of CONESA and CIGEMEX were conducted. ${ }^{12}$ Amcham represents the historically most important foreign MNE subsidiaries. CONESA (food) and CIGEMEX (chemicals, pharmaceuticals) are highly relevant for our topic due to their size, the sensitivity of their sectors, and their uninterrupted presence in Mexico during the period of investigation. Even though this sample is not representative of MNEs in Mexico, it allows one to illustrate, question, and qualify conclusions based on statements from the CEMEFI, FMCT and USEM, which were representative carriers of CSR and TQM discourses, respectively.

\section{Results}

\subsection{Enhanced Legitimacy through Denationalised CSR Discourse and a Changing Economic and Political Context (1970s and 1980s)}

MNEs have been engines of globalising capitalism for centuries (Chandler and Mazlish 2005; Dunning and Lundan 2008; Jones 2005). However, in the context of the 1960s, marked by decolonisation, popular conscience about the gap between "developed" and "underdeveloped" countries, as well as U.S. hegemony in many parts of the world, they started attracting considerable political and academic attention at an international level. Most MNEs were headquartered in the U.S., for which they were considered an expression of U.S. dominance and a challenge to national interests (Bair 2009; Hajduk 2013; Maurel 2011; Oliveiro 2010). ${ }^{13}$ Such scepticism was usually mixed with positive considerations on MNEs' impact in terms of investments, technology transfer, and employment. Mexico was the case in point. Harvard economist Raymond Vernon, who had a considerable impact on the international debate with his 1971 book Sovereignty at Bay, ${ }^{14}$ had started working on the topic with the example of Mexico. His 1963 book The Dilemma of Mexico's Development ${ }^{15}$ was about policies that enabled a developing country in need of capital and technology from abroad to overcome contradictions between foreign and particularly MNEs' interests with

12 Carlos Eduardo Represas, born in Mexico City in 1945, was CONESA's CEO (1983-1994) and chairman (1983-2004). He was interviewed in Mexico City on 27 April 2017 and 18 May 2018. Peter Reinartz, born in Puebla in 1946, was director of the agricultural division (1979-1983), CEO and chairman of CIGEMEX (1989-1996), and chairman of Novartis México (1997-2000). He was interviewed in Querétaro on 6 May 2017.

13 Additionally in countries like France; see (Servan-Schreiber 1967).

14 (Vernon 1971).

15 (Vernon 1963). See also (Vernon 1964). 
those of the host country. In 1980, another U.S. American scholar wrote that Mexico had found a middle-way between restricting and attracting MNEs, and inspired many other developing countries (Sigmund 1980, p. 48). ${ }^{16}$ This positive conclusion did not represent a consensus. ${ }^{17}$ However, a common opinion in both the academic and political debate was that MNEs were a powerful and growing phenomenon, which had to be investigated and regulated. This sceptical stance reflected a crisis of legitimacy of global capitalism in Mexico and around the world. During the 1970s, which saw the end of the post-war economic "miracle", this crisis reached its turning point, from which one can reconstruct MNEs' changing economic and cultural role in Mexico.

Mexico's leftist president Luís Echeverría (1970-1976) was one of the most important champions of the New International Economic Order, which was promoted by Third World countries and aimed at strengthening governments' role in the world economy, for instance through major control of MNEs by their host countries (Bair 2009, p. 350; Burke 2012, p. 440). ${ }^{18}$ Echeverría's government introduced or changed several laws with the same purpose, provoking confrontations with Amcham. For some time, the president had the support or sympathy of an important part of Mexican business. MNEs' resources exceeded by far those of the mostly smalland medium-sized domestic enterprises. This induced concerns even with those businesses that did not compete directly with them. Moreover, since World War II, U.S. corporations had greatly expanded in the manufacturing and consumer goods sectors. Their products and marketing methods influenced consumer behaviour, for which they had a broader impact on Mexican society than the previously arrived corporations from extraction sectors. ${ }^{19}$ Domestic businessmen criticised this as undermining Mexican culture. They felt under increasing social and political pressure themselves. Since the 1960s, USEM, an association of businessmen inspired by Catholic social teaching (CST), had developed a discourse on business's role in society. It organised public events directed at the business community and society at large, invited labour and government representatives, and participated in an

16 The country's importance in academic research is shown by further international contemporary contributions such as (Baumer and Gleich 1982; Fajnzylber and Tarrago 1976; Iffland and Galland 1978; Krook 1976; Matthies 1977; Montavon 1979; Newfarmer and Mueller 1975).

17 Moreover, domestic scholars deemed MNEs too influential, and claimed they gained more from Mexico than they provided. See for instance (Aguilera 1975; Bernal 1976; Chapoy Bonifaz 1975; Sepúlveda et al. 1974).

18 For an overview of Echeverría's presidency, see (Schmidt 1991).

19 For the expansion of U.S. corporations in Mexico, see (Moreno 2003; O'Brien 1999; Rosenberg 1982). 
international circulation of CSR ideas, notably the one run by the International Christian Union of Business Executives (UNIAPAC). This CSR discourse was critical of global capitalism and promoted the idea of companies as humanist, family-like, patriarchal communities. For both economic interests and cultural motives, Mexican businessmen viewed MNEs with suspicion. ${ }^{20}$

However, the impression that the government became ever more hostile to private business made a growing number of them change their view of MNEs. Concerns about socialism increasingly outweighed such about national values and interests. Big Mexican corporations cooperated with foreign MNEs to both fight Echeverría's policies and denationalise CSR discourse. In 1975, they set up the powerful umbrella association Consejo Coordinador Empresarial (Luna and Tirado 1992), which adopted CST-inspired CSR discourse, but swiftly excluded the question of a company's national origin from it. Social legitimacy should no longer be nationally connoted (Gertschen 2017, pp. 546-53). ${ }^{21}$ For its part, Amcham criticised an "unprecedented attack" on "free enterprise" in Mexico and around the world. ${ }^{22}$ It launched a so-called communication program to convey the benefits that U.S. MNEs brought to Mexico. It conducted opinion surveys, published articles, awarded prizes to socially beneficial business practices among its members, invested in a program for young entrepreneurs, and consulted corporations on new issues such as "public services" and "public relations" (Amcham 1974a, 1974b, 1977). In 1977, five years after launching the program, Amcham conceded that up to that time, most members had "lived by the maxim 'The business of business is business.' Low profile and non-involvement were the passwords" (Amcham 1977, p. 35). It is hard to gauge the impact of the program, aimed at establishing or improving relationships with a variety of stakeholders. The experiences of Nestlé's subsidiary (CONESA) ${ }^{23}$ and of

20 For business' CSR discourse in Mexico during the 1960s and 1970s, see (Gertschen 2017).

21 On the cooperation between domestic big business and foreign MNEs, see also (Arriola 1976; Basáñez 1991, pp. 196, 219).

22 See the Amcham president's statement in (Loretta 1973, p. 13).

23 The Nestlé executive board was well aware of the "quite exceptional" fact that CONESA remained completely foreign-owned (Swiss) when many MNE subsidiaries were forced to open up to Mexican capital, and that this was due to the close relationship between CONESA's president José Represas (father of Carlos Eduardo, see footnote 12) and the presidents Echeverría and López Portillo. See the letter by executive board member Carl L. Angst to his board colleague Camillo Pagano of 17 October 1980, in: AHN, NES C1.5/1700-93. For an appreciation of Represas' extraordinary political skilfulness by his superior in Vevey, see the "Lettre-circulaire" addressed to all general directors in Latin America by Pagano of 20 October 1976, in: AHN, NES C1.5/1700-8. Meetings with López Portillo, which demonstrate Represas' political standing beyond Echeverría's administration, are mentioned in 
Ciba-Geigy Mexicana (CIGEMEX) ${ }^{24}$ suggest that in the de facto one-party regime of the Partido Revolucionario Institucional (PRI), relations with the administration and particularly the president remained paramount. Therefore, MNEs' quest for legitimacy was decisively facilitated by the change of presidency. Echeverría's successor José López Portillo (1976-1982) saw a political benefit in improved rather than strained relations with domestic and foreign business.

Moreover, in Switzerland, Nestlé and Ciba-Geigy were confronted with stakeholders-and the public at large-that viewed them with increasing scepticism. ${ }^{25}$ With Nestlé, this concerned mainly the corporation's role in Third World countries; with Ciba-Geigy the ecological effects of chemical production and social implications of rising medicine prices in developed countries must also be noted. ${ }^{26}$ Therefore, their subsidiaries' quest for legitimacy in Mexico was part of an effort of the whole group to cope with changing societal conditions and expectations (Gertschen 2019). However, in the case of Mexico, it is plausible that political and economic conditions again were more important factors for the further improvement of MNEs' status. In autumn 1982, the government had to declare default and thus triggered a debt crisis which would soon have global repercussions. In 1985, after failed attempts to stabilise the country within the traditional state-interventionist scheme, president Miguel de la Madrid (1982-1988) started liberalising the economy. However, only his successor Carlos Salinas (1988-1994) abandoned the regime's revolutionary discourse, which equated government with the state, and the state with society. He postulated

the minutes of CONESA's executive board meeting of 20 May 1977, 15 March 1978, and 11 September 1978, in: AHN, NES C1.5/1700-4.

24 Furthermore, in the mid-1980s, when the government was in a much weaker position due to economic and financial problems, and its rhetoric on MNEs was no longer antagonistic, CIGEMEX considered itself "extremely vulnerable [ ... ] due to the political nature" of its agrochemical and pharmaceutical business. Quote from general director J. P. Scott in Issue Management Committee, Minutes of the Meeting of the IMC 3-1985, 8 May 1985, in: FAN, Ciba-Geigy Mexicana, Korrespondenz Divisionen und Dritte, 1986, Akten Dr. S. Schmid, RD 06.07.01. Accordingly, even at a time when the regime's grip on society was beginning to ease, the only addressees of PR activities were authorities; see the document "Major problems and opportunities 1987/1988-Key projects", in: FAN, Ciba-Geigy Mexicana, "Korrespondenz Divisionen und Dritte", 1987, Akten Dr. S. Schmid, RD 06.07.01.

According to Kuhn, the emergence of a Third World discourse in Switzerland during the late 1960s and early 1970s was inextricably linked with the rising criticism of MNEs based in the country. See (Kuhn 2012, pp. 278-81; Kuhn 2009, pp. 115-20). An important contribution from a business history perspective is (Pitteloud 2019, esp. ch. 7 and 8).

26 The most famous and best researched case is the campaign against Nestlé's infant formula business, see (Kalt 2009, 2010; Sasson 2016; Sethi 1994). A general account of Ciba-Geigy and Novartis, which tackles the shrinking social legitimacy of Ciba-Geigy and the chemical industry in general, is provided in (König 2016). An insightful journalistic contribution is (Bürgi and Imfeld 2004). 
that national sovereignty and development could and should no longer be only the government's responsibility. Civil society and business mattered, too, especially in the context of globalisation in which competitiveness was as vital for sovereignty as territorial control. ${ }^{27}$ In this vein, Salinas' (neo-)liberal discourse justified an important—and lasting — shift in power relations. Before the crisis, MNEs had to demonstrate their social responsibility and trustworthiness to be allowed to operate in Mexico. Afterwards, the burden of proof was reversed. It was the country and particularly its government that needed to be endorsed. An MNE like Nestlé actually did so, affirming in newspaper ads that it was "a good moment to invest in Mexico". ${ }^{28}$ With president de la Madrid, Mexico's sheer necessity improved MNEs' status; with president Salinas, it was their depiction as symbols of development and competitiveness.

\subsection{Enhanced Competitiveness by Adapting to and Shaping Society (1980s and 1990s)}

MNEs were not ready to live up to these high expectations from the start. Their subsidiaries had grown used to protectionism. Most of them had been established to circumvent trade barriers and serve the Mexican market, not to compete internationally. The depressed domestic market and increased import competition put both Mexican and foreign businesses under enormous pressure. ${ }^{29}$ Being part of an MNE provided foreign subsidiaries with more resources than domestic companies, but also exposed them to increasing competition within the group. Like other MNEs, Nestlé and Ciba-Geigy wanted to benefit from trade liberalisation by serving different national markets from centralised production units, thus realising economies of scale. ${ }^{30}$ The North American Free Trade Agreement,

27 On Salinas' neoliberal "reinvention" of Mexico, see (O'Toole 2010, chp. 2 and 4).

28 "Si en 1930 Nestlé tuvo confianza en México, ahora con más razón”, "Informador", 24 September 1986, p. 9A.

29 For accounts of CONESA's struggle, see the minutes of the board of directors meeting of 28 July 1981, and the letter of then-General Director C.E. Represas to José Daniel, member of Nestlé group's executive board, of 28 February 1984, both in: AHN, NES C1.5/1700-4. For difficulties of chemical and pharmaceutical companies, including Ciba-Geigy, see the interview with P. Reinartz on 6 May 2017. de la Garza (1999) provides a more general account of the radical restructuring of Mexico's manufacturing industry during the 1980s and 1990s.

30 This meant for instance that former CIGEMEX products could be supplied by Ciba-Geigy U.S.A. See Agricultural Division, Major problems and opportunities 1987/1988, in: FAN, Ciba-Geigy Mexicana, Korrespondenz Divisionen und Dritte, 1987, Akten Dr. S. Schmid, RD 06.07.01. For respective efforts by Nestlé in Europe and North America, see the annual reports of 1990, p. 7, and of 1991, pp. 6-7. According to (Bielschowsky and Stumpo 1995), Mexico's foreign trade was decisively boosted by intrafirm trade of MNEs. 
which entered into force on 1 January, 1994, decisively added to this context. During the second half of the 1980s and the 1990s, CIGEMEX made great efforts to improve productivity and quality. It introduced TQM, flexibilised labour relations, and reduced the workforce. ${ }^{31}$ With CONESA, a similar process occurred. ${ }^{32}$ It seems plausible that the integration into the global market boosted awareness that MNE subsidiaries relied on a competitive and cooperative environment, if they were to prosper. In their internal and external communication, CIGEMEX and CONESA depicted their efforts to become more competitive as part of a national effort. ${ }^{33}$ During the 1990s, CIGEMEX launched several collaborative projects aimed to fight lepra (partnering with government), to promote the responsible disposal of toxic waste and help improve laboratory safety at universities, or to promote ecological technology innovation (partnering with various academic institutions). ${ }^{34}$ According to then-CEO Peter Reinartz, they improved relations with stakeholders, because they were based on a real and shared interest. Only one was a mere "marketing gimmick". ${ }^{35}$

31 See 3rd Quarter Review 1986, section 1 “Major Aspects and Outstanding Issues for Parent Company's Attention", in: FAN, NoAr, Regionsdienste, CIGEMEX, Protokoll MC 23 June 1986, RD 06.07.01; the confidential report by R. H. Muhr on his Mexico trip, dated 25 November 1986, in: FAN, Ciba-Geigy Mexicana, Korrespondenz Divisionen und Dritte, 1987, Akten Dr. S. Schmid, RD 06.07.01; and the comments on TQM by the responsible for Latin America at group level in El Dr. Rolf A Meyer acompaña a la representación suiza ..., in: Imagen, ed. by Ciba-Geigy Mexicana, August 1995, pp. 6-7. General Director P. Reinartz wrote of "painful decisions" that had to be taken, see Editorial, in: Imagen, ed. by Ciba-Geigy Mexicana, November 1993, p. 3.

32 Interview with C.E. Represas on 18 May 2018.

33 Illustrative of this framing is, for instance, Los mexicanos también hacemos calidad total, in: Imagen, ed. by Ciba-Geigy Mexicana, November/December 1989, p. 15.-CONESA was a founding member and C.E. Represas a board member of the below described Fundación Mexicana para la Calidad Total (FMCT), and both CONESA and CIGEMEX participated in TQM events; see Calidad Total, Monografías 7, ed. by FMCT, México D.F. 1991; El Hombre y la Calidad, V intercambio internacional (advertisement), "Informador", 25 February 1990, p. 9A; XIX Congreso Nacional de Control de Calidad (adv.), "Informador", 8.9.1991, p. 3A; Primera Cruzada Jalisco por la Calidad (adv.), "Informador", 20 October 1999 , p. 2 G.

34 For the lepra project, see Sigue la colaboración del Fondo Ciba Contra la Lepra, in: Imagen, ed. by Ciba-Geigy Mexicana, August 1996, p. 4; Se ha registrado reducción en la incidencia de lepra, "Informador", 17 October 1996, p. 11A. Ciba-Geigy had set up a fund to fight lepra in ten countries during the 1980s; see (Bürgi and Imfeld 2004), p. 188. For the project on ecological technology innovation, see Premio Ciba de Innovación Tecnológica en Ecología, in: Imagen, ed. by Ciba-Geigy Mexicana, October 1993, pp. 3-4; Se entregó el III Premio Ciba ... , in: Imagen, ed. by Ciba-Geigy Mexicana, May 1996, pp. 10-11. For the project on the disposal of toxic waste, improved laboratory safety, and traineeships to students, see the interview with P. Reinartz on 7 May 2017.

35 P. Reinartz on an epilepsy campaign during these years to win doctors' favour. Interview with P. Reinartz on 7 May 2017. 
CONESA had established comparable collaborations already in previous decades, and continued corresponding efforts. ${ }^{36}$

Business CSR and TQM discourses demonstrate that intensified relations between MNE subsidiaries and their local environment, and the concomitant interplay of economic cooperation and cultural change, were a more general phenomenon closely connected to global market integration. Already during the 1970s, carriers of CSR discourse had promoted the positive interrelatedness of social responsibility, productivity, and quality. Andrés Marcelo Sada (born in 1930) was arguably most important in voicing that the company be "humanistic for both its proper and for social interest" (Sada 1978, p. 3). ${ }^{37}$ He was a founding member of USEM's chapter in Monterrey, and headed the chemical company Celulosa y Derivados S.A. (CYDSA). CYDSA was part of the "Grupo Monterrey" —an ensemble of corporations based in Northern Mexico's industrial centre owned by a few intermarried families with multiple relations with foreign MNEs as clients, suppliers or joint venture partners. ${ }^{38}$ According to the human resources director of a Grupo Monterrey company, who held a speech about workers' participation at USEM Monterrey in 1975, internationalisation made workers' reality "more similar to that of the European than to the average Mexican worker" (Valdés 1976, p. 15). The automotive industry, dominated by U.S. and European corporations, was paramount for the introduction of new technical and social norms in Mexico. ${ }^{39}$ As of the early 1980s, MNE subsidiaries started applying standards and processes of statistical control and continuous improvement of quality, and soon requested the same from their providers (Gutiérrez 1992, p. 61). ${ }^{40}$

36 In the interviews on 26 April 2017 and 12 May 2018, C.E. Represas claimed that CONESA had focused on creating value for both the company and society since its establishment in the 1930s. Nestlé has sustained this claim with many publications, such as "An illustration of Nestlé's role in developing countries: Example of the State of Chiapas, Mexico", excerpt of the report of Rémy Montavon, Geneva 1972, and Ganadería lechera en el trópico húmedo de México. Experiencia de una década en la Chontalpa, Compañía Nestlé S.A., México D.F. 1986. CONESA's continued efforts to foster good relationships with its environment are documented by (Montavon 1994; Soberón et al. 1995, pp. 17-18). However, there was also criticism that such efforts were not successful or only intended for the company's benefit. See for instance (Bertolami 1983); Convention d'actionnaires (probably 1985); (Harrisson 1982).

37 For one of his many public contributions on the topic, see also his opening speech at the First International Symposium on Productivity, and Quality of Working Life in Monterrey in 1979; see (Sada 1980).

38 On CYDSA and the Grupo Monterrey in general, see (Montavon 1979; Cerutti 2000; Flores 2000; Pozas 2002).

39 For an overview see (Gereffi 2003; Humphrey et al. 2000). On the change of labour relations in particular, see (Luján Uranga 2011; Pries 2000).

40 The importance of the car industry is also stressed in (Calidad Total 1990; Gutiérrez 1991, p. 260). 
The Instituto Tecnológico de Estudios Superiores de Monterrey (ITESM), a university of applied sciences founded by the Grupo Monterrey, established the "Centro de Calidad" in 1982. Two years later, in cooperation with Ford, the ITESM launched a program to build up TQM capacities in the whole of Mexico's automotive industry; later it was also incorporated in the chemical, metal manufacturing and service industries (Gutiérrez 1992, pp. 63, 279). ${ }^{41}$ In the same context of enhanced global market integration and competition, USEM Monterrey held two major conferences on CSR in the light of supply chains and stressed the importance of improved relations with workers, trade unions, suppliers, and even competitors (Farias Arizpe 1985, p. 5; Ardavín 1987).

The creation of the foundation FMCT in 1987, and the establishment and subsequent revaluation of the National Quality Award (Premio Nacional de la Calidad) between 1986 and 1989, were milestones of TQM discourse. ${ }^{42}$ At least half of the 22 founding members of the FMCT, and most of the Award winners, were MNE subsidiaries or suppliers of such corporations. ${ }^{43}$ The FMCT mission was "to boost and promote a Total Quality culture in Mexico, adequate to our context" (Gutiérrez 1991, p. 262). Precisely this context was seen as the greatest challenge. Julio Gutiérrez, the first FMCT president, acknowledged that "the tools and technologies of quality are useful and important. But the Foundation considers that they are insufficient to render the country really competitive." Overcoming "obsolete beliefs" was needed, such as considering criticism as a lack of respect for the superiors, formal authority as always being right, the foreign as always being superior, or Mexicans as unable to work in groups (Gutiérrez 1991, pp. 264-65). In this quest for cultural change and economic success, history was evoked. FMCT director Joaquín Peón resorted to a famous anthropologist's thesis of the two Mexicos that had existed since the

41 For the introduction of TQM measures in a Grupo Monterrey company as of the 1970s, see the speech by CYDSA chairman Andrés Marcelo Sada in Calidad Total 1991, Monografías 6.

42 The FMCT organised conferences, published "Calidad Total" (with the edition lines "Casos", "Monografías", and "Perspectivas"), and pushed the government for rehauling the National Quality Award launched in 1986. See the latter on Agustín Portal, of the Ministery of Commerce and Industrial Promotion, in: (Calidad Total 1991, Monografías 6, pp. 1-2).

43 Among the founding members, Alcatel Indetel, Celanese Mexicana, Hewlett-Packard de México, Industrias Resistol, Unión Carbide Mexicana were MNEs. Suppliers were for sure: Alfa Corporativo, Conductores Latincasa, CYDSA, Grupo Condumex, Metalsa, Vitro Bienes de Capital. This does not exclude that among the following members there were more MNE subsidiaries or suppliers: Banamex, Celloprint, Cía. Industrial San Cristóbal, Consultoría en Productividad, Corporación Industrial San Luis, Gigante, Promociones Industriales Banamex, Rassini, Real Turismo, Seguros América, Texel. See (Calidad Total 1989), backside. The annual winners were presented in the various FMCT publications. 
Spanish conquest. "Deep Mexico" was indigenous, traditional, and suppressed by modern, European "imaginary Mexico" (Bonfil 1987). Peón did not share this thesis. The point he made was that both their indigenous and modern heritage provided examples that Mexicans cared about the distinction between the bad, the regular and the best, and about excelling models. "The National Quality Award refers to this part of our collective ethos and responds to our necessity to have new heroes and to dispose of an instrument that fosters the optimum development of Mexican organisations [ ... ]" (Peón Escalante 1991, p. 2). Accordingly, total quality was "as an updated form of giving continuity to the fundamental values [ ... ] of our culture" (Peón Escalante 1991, p. 2). ${ }^{44}$ José Giral, the second FMCT president, expressed the same when calling for a "synthesis", a "Mexican modernity" (Giral 1991, pp. 23-24).

However, this vision of an evolutive and somewhat harmonious process was contradicted by the same protagonists who declared that Mexico needed a "cultural revolution" (Peón Escalante 1991) ${ }^{45}$ From an embeddedness perspective, this ambivalence was no coincidence. TQM discourse worked two ways. The consideration of the company as part of society led Mexico's National Quality Award, in contrast to contemporary awards in Japan, the U.S. and Europe, to pay special attention to a company's impact on its environment. ${ }^{46}$ The premise was that business had to respect and adapt to society and nature. Nevertheless, as a management idea and method, TQM aimed to understand, control, and use the social and material world. Accordingly, TQM discourse intended to shape society, to adapt Mexico to the "changed environment". ${ }^{47}$ This environment was described in terms of modernity and, in its most powerful form, the global market. ${ }^{48}$ Despite horrendous economic hardship, carriers of TQM discourse connoted the forced change positively. The removal of attendance recorders, formalities in day-to-day communication such as titles, or car lots hitherto exclusively assigned to executives, were presented as symbols of a more equal and human "new corporate culture" (Giral 1991, pp. 235-55; Peón Escalante 1991, p. 2; Zárate in Calidad Total 1991, pp. 22-26). Total quality's

44 The minutes of the 1990 congress, at which Peón held this speech, were published in various "Monografías".

45 According to Giral (1991, p. 14), Mexicans needed to "revolutionise" their perceptions and attitudes.

46 For the criteria, see "El Premio Nacional de Calidad", (Calidad Total 1991, Monografías 4, pp. 16-22). This difference with other quality awards was highlighted in (Gutiérrez 1991, p. 266), by foreign speakers at the 1990 congress; see (Calidad Total 1991, Monografías 5, pp. 12, 23), and is still today on http://www.pnc.org.mx/nuestra-historia-2/ (last accessed on 24 October 2019).

47 See José Giral's introduction in: Más allá de la Calidad Total, Memorias del VIII Congreso Internacional de Calidad, México D.F. 25./26.11.1996, p. II.

48 See the paradigmatic book (1991), featuring many important businessmen as authors. 
promise was a better Mexico in all possible aspects, and globalisation was perceived as a helping hand in this endeavour (Giral 1991, pp. 10,17-18; Gutiérrez in Calidad total 1991, p. 268).

During the late 1980s and early 1990s, TQM and CSR discourses mutually reinforced each other. Catholic social teaching (CST) was rooted in the $19^{\text {th }}$ century, for which it endowed catholic CSR discourse with a memory of modernity's and particularly capitalism's negative social and cultural effects. Consequently, this discourse was more conservative and sceptical of the sweeping economic liberalisation than TQM discourse. However, it also promoted the idea that the ethically good would prevail in the global market, that a virtuous circle of social responsibility, quality, competitiveness, and prosperity was possible and actually required by competitiveness. ${ }^{49}$ TQM and CSR discourses were sustained and interrelated by people and companies, relatively small in number and partly identical, $^{50}$ which certainly contributed to the consistency of this message-but also to its limited reach.

The efforts and difficulties to spread the idea and practice of this virtuous circle can be exemplified by the second FMCT president José Giral. Born in 1938, a chemical engineer from the National Autonomous University of Mexico (Universidad Nacional Autónoma de México, UNAM), he spent the first two decades of his professional career with the U.S. MNE DuPont. Between 1983 and 1993, he directed the Mexican corporations Pliana and Grupo Xabre. From 1968 until at least 2004, he belonged to an UNAM group that investigated culture and technology from

49 On the necessity of breaking the "vicious" and entering the "virtuous circle", see (Ardavín 1987, p. 12); Elizondo in (Ardavín 1987, p. 2), and Andrés M. Sada in "Foro Nacional Balance Social" (Sada 1989, p. 26). Significant was the manual (Confederación USEM 1993), which synthesized decade-long reflections at USEM, and integrated CSR and TQM discourse. For elaboration, see (Revista USEM 1997, p. 13).

50 For instance, Carlos Llano, Augusto Pozo Pino, and Andrés Marcelo Sada belonged to the FMCT Board of Directors (enlisted in all publications). They all played an important role in CST-oriented CSR discourse as of the 1970s. See Actas del Consejo Central de Delegados de América Latina de la Uniapac, Caracas, 18-21 November 1970, or Acta del CCDAL de la Uniapac, Quito, 26-28 September 1973, both in: Conf. USEM, CCDAL 1970, 1971 and 1973; or the news section in: Boletín USEM México, (Jun. 1973, p. 4). At the beginning of the 1970s, Condumex corporation, headed by the later FMCT president Gutiérrez, collaborated with USEM to promote best practices in stakeholder relations. See Visita a Condumex, in: Boletín USEM México, Mar. 1972, pp. 2-3; news section in Boletín USEM México, (Aug. 1972, p. 4). Moreover, Grupo Bimbo of the leading USEM members Lorenzo and Roberto Servitje both referred to and were present in TQM discourse, see Tarin (1990, pp. 8-12); and Servitje (in Más allá de la Calidad Total, pp. 186-97). 
a management perspective and offered consulting services. ${ }^{51}$ In his 1991 book "Culture of Effectivity", Giral wrote that management could not force cultural change, "only guide, facilitate and accompany it" (Giral 1991, pp. 23-24). He was optimistic that "in any circumstances, our people can act with great productivity, creativity, and responsibility, if they are inspired and freed from obstacles" (Giral 1991, foreword). In the book's second edition of 1993, he recognised that changing corporate culture was proving difficult, especially with small companies, and explained it with Mexican culture (Giral 1993, pp. xi-xiv, 11-12). Acknowledging culture's importance was one thing, re-engineering it quite another. ${ }^{52}$

\subsection{Polarisation and Consolidation of the Two Mexicos (1990s and 2000s)}

The gap between ambition and reality was revealed in a brutal and unequivocal manner by the so-called Tequila crisis, a financial and economic crisis that began in December 1994 amid the change of presidency from Carlos Salinas to Ernesto Zedillo (1994-2000). Growth picked up in 1996, again, but did not prevent rising bankruptcies, unemployment, and poverty (Dussel Peters 2000, Middlebrook and Zepeda 2003; Pozas 2006). Already in early 1994, in a manifesto for the future administration, three major business associations had jointly called for a "market economy with social responsibility" (Propuestas 1994, ch. IV). This implied that the "big part of medium, small and micro enterprises", for which liberal policies had brought about "adverse results", should get a bigger share of economic growth (Propuestas 1994, pp. 3, 16). ${ }^{53}$ Indeed, the dual structure of Mexico's dual economy had been taking shape since the early 1980s, as a result of companies', sectors', and regions' highly different capacities to react to international competition. The "Tequila crisis" and its aftermath revealed and exacerbated this polarisation. ${ }^{54}$

Between 1999 and 2004, José Giral co-authored four more books on competitiveness. They all insisted on the central message of CSR and TQM discourses that socially and ethically responsible business behaviour paid off economically

51 See quiminet.com/articulos/forjadores-de-la-quimica-en-mexico-jose-giral-barnes-2634425.htm (4 October 2019), and interview with J. Giral on 11 April 2016.

52 A business consultant and bestselling author shared Giral's appreciation, see (Münch Galindo 1992, pp. 144-55). The book was updated twice and still sold in 2006.

53 A fourth business association criticised that an "oligopolistic market structure" left only crumbles for the "immense majority" of businesses, see (Concamin 1994, p. 3).

54 Dussel Peters (2000) and Pozas $(1994,2002)$ demonstrate that big domestic and multinational enterprises were in a much better position than SMEs, and that regions with no or little MNE presence and integration into global value chains fared particularly badly. 
(Giral et al. 2004, p. 98). ${ }^{55}$ According to Giral and his co-authors, a major reason why most companies were unable to enter this virtuous circle was that the crisis had devastated most value chains. Globalisation "conspired" against re-articulating them, because corporations imported supplies instead of integrating national SMEs into their value chains (Giral et al. 2002, pp. 17-18). For the authors, an aggravating factor was foreign control of most corporations, because they were even less inclined to invest in national suppliers and commit themselves to Mexico. They suggested measured state intervention, including incentives for Mexican-controlled big business to create local value chains (Giral et al. 2002, pp. 17-18; Giral et al. 2004, pp. 118-19). About 25 years after the question of foreign capital had been excluded from business CSR discourse, they brought it back. However, such criticism had little echo in Mexican business and politics. Only one major business association seems to have broadly shared Giral and his fellows' analysis. ${ }^{56}$ For several reasons, even in the context of renewed and massive economic hardship, the role of MNEs was not broadly questioned. Mexican corporations were becoming multinational themselves. Then, there were important differences between foreign MNEs, which can again be illustrated with Nestlé and Ciba-Geigy/Novartis. The former expanded its activities in Mexico. Today, the country is the company's fifth largest market worldwide. ${ }^{57}$ Novartis México, on the other hand, divested during the 1990s, ${ }^{58}$ and has further reduced its capacities in the country since then. ${ }^{59}$ Most importantly, by the mid-1990s, MNEs had acquired a position of economic power and normative authority, which protected them from broad criticism.

Business CSR discourse is revealing of this privileged position. After the "Tequila crisis", representatives of USEM continuously denounced the global market for its economic effects and normative foundations (Milanés 1995, p. 1; Milanés 1996, p. 1;

55 For the importance of business ethics and CSR for competitiveness, see (Giral et al. 1999, p. 7; Giral et al. 2000, p. 5; Giral et al. 2002, p. viii; as well as Giral et al. 2004, pp. 100, 127-35).

56 Though it did not explicitly mention corporations as co-responsible for the country's malaise, see (Concamin 2000). For its part, contemporary academic research confirmed Giral's and his co-authors' analysis, see for instance (Zepeda and Lugo 1999).

57 Today, Nestlé México has more than 13,000 employees, see (Nestlé 2018). In 1983, when the subsidiary was facing bankruptcy, it counted less than 3500, see the letter of then General Director C.E. Represas to José Daniel of 28 February 1984 in: AHN, NES C1.5/1700-4.

58 For the development of Novartis' activities in Mexico until the turn of the century, see (Zeller 2001, pp. 146, 491-96, 525-39).

59 Today, there is no production facility anymore. See (El Universal 2018). 
Loza Macías 1998, p. 1; Castillo Peraza 1999, pp. 15-24; Revista USEM 2001). ${ }^{60}$ However, MNEs as the agents of the global market were anathema. The example of CEMEFI (Centro Mexicano para la Filantropía), which was founded in 1988 and became the most important carrier of CSR discourse in Mexico at the turn of the $2000 s,{ }^{61}$ is even more telling. CEMEFI differed from USEM in various aspects. For instance, it was secular (not adherent to CST), it tackled CSR as a corporate issue (not as a question of personal leadership, integrity, and spirituality), and foreign MNEs played a crucial role. U.S. corporate foundations served CEMEFI as financial supporters and role-models for Mexican civil society. ${ }^{62} \mathrm{MNE}$ subsidiaries such as CONESA were among its first members and partners for campaigns. ${ }^{63}$ In 2001, CEMEFI launched the "Distintivo ESR", which was based on a self-assessment and grew rapidly to become Mexico's best-known CSR award. ${ }^{64}$ The overwhelming majority of the first companies to receive the award were MNE subsidiaries. Again, CONESA and Novartis México were among them. ${ }^{65}$ Economically successful and complying with relatively high standards, they served as examples that the business case of CSR promoted by CEMEFI actually worked. Vice versa, CEMEFI's discourse promoted the cognitive and normative ideas, and the institutions-the cultural context-that facilitated MNEs' integration and the cooperation with them. It even represented MNEs' enhanced embeddedness in globalised Mexico.

60 An interview with Kenneth Arrow was entitled "Stop the savage economy!", even though this economist did not use the expression. See ¡Basta con la economía salvaje!, in: Revista USEM, May-June 1995, pp. 12-13, 205.

61 On CEMEFI's status, see (Agüero 2005, p. 121; Gordon Rapoport 2008, pp. 83-89; Grayson and Nelson 2013, p. 25).

62 For the CEMEFI's official account, see (CEMEFI 1996, p. 14) and (CEMEFI 2016). (Fernández 1995) is an example of the model character ascribed to civil society in the U.S. and Canada. For an academic contribution, see (Gordon Rapoport 2008, pp. 67-68, 78).

63 For the corporate philanthropy program "Mira por los demás", see Informe 1995-1996, p. 28, and Acciones y logros en 10 años de trabajo. Resumen del documento de Dr. Rubén Aguilar del CEMEFI presentado en la reunión previa a la Asamblea de Gobernadores del BID en 1998 en Cartagena de Indias, p. 5, in: CEMEFI, MIC f 57. Moreover, CONESA set up an important health fund in the 1990s (Soberón et al. 1995). In 2000, about half of CEMEFI's corporate members were of foreign origin, see Informe Anual 2000, p. 40.

64 CEMEFI: Distintivo ESR a la Empresa Socialmente Responsibleß, Edición 2003, in: CEMEFI, F1288. In 2001, 17 companies received the award, in 2002 28, in 2003 41, in 2004 61, in 2005 84, in 2006 124, and in 2017, 1505. See (CEMEFI 2007, p. 21) and https://www.cemefi.org/buscadoresr/\#/ (8 December 2017).

65 See (CEMEFI 2006, p. 23). 


\section{Discussion and Conclusion}

Business' CSR and TQM discourses in Mexico represent a profound change of MNEs' embeddedness in this country during the period from the 1970s to the early 2000s. They turned from actors with little social legitimacy to the centres of the globalising part of Mexico's dual economy. MNEs' central role consists of both their "hard" economic power, especially their ability to coordinate global value chains, and their "soft" power, which refers to their perception as role models that succeed in creating a virtuous cycle of competitiveness and social responsibility. Indeed, the emergence of Mexico's dual economy was both an economic and cultural phenomenon. Local business did not only engage in economic activity with MNE subsidiaries but shared and jointly promoted cognitive and normative ideas about the challenges of the global market, and how they could be met. This cultural process implied a better adaption by MNEs to the Mexican context, but local actors' increasing compliance with the standards set by MNEs. MNE's enhanced embeddedness worked two ways; it was about adapting to and shaping society. It meant a new, an increasingly trans-nationalised governance for the Mexican economy. ${ }^{66}$

In the light of SDG 8, this analysis offers various conclusions. Globalised Mexico could serve as an example that, in the context of the global market, economic growth, decent working standards and corporate social responsibility, in the wider sense, are compatible, if not mutually beneficial. However, it also demonstrates the limitations of this dynamic. The majority of businesses, consisting of micro, smalland medium-sized enterprises, have not entered the virtuous cycle of economic competitiveness and social responsibility. Obviously, this positive interplay is contingent; it works under certain circumstances, but not necessarily and not for all. This is even demonstrated by globalised Mexico itself. Recent studies suggest that working conditions in MNE subsidiaries are still clearly better than the national average, but that employment stability and remuneration have come under increasing pressure (Bensusán et al. 2018, p. 13; Bensusán and Carrillo 2017, p. 36). ${ }^{67}$

The positive economic and social effects of global capitalism are neither enjoyed by everyone nor can they be taken for granted. Such are the rules of this game. However, the legitimacy of this social order requires that these rules not be applied

66 On the concept of transnational governance, and the importance MNEs play in it, see (Djelic and Sahlin-Andersson 2006; Folke Schuppert and Zürn 2008; Gereffi et al. 2005, pp. 78-104).

67 On the different types of foreign direct investment, and the opportunities and risks associated to them-such as a "race to the bottom" of wages and working conditions in the face of global competition—see (Carrillo et al. 2012b, p. 84; Mortimore 2006). 
too strictly. Otherwise, resistance grows. Since the "first globalisation" of the 19th century, expanding global capitalism and economic nationalism have been two sides of the same coin. ${ }^{68}$ It depends on the historical context what side is up; neither force can be considered dead. By adapting to and shaping society, MNEs have had important merits. However, expressing both the rejection of nationalism as a zero-sum ideology directed against other nations, and the confidence that private business is key to globally sustainable development, the UN Agenda 2030 bestows MNEs with an even greater responsibility. They have to deliver more. ${ }^{69}$ This is what the example of Mexico suggests, too.

Funding: This research was funded by the Gerda Henkel Foundation, grant number 42/F/14.

Conflicts of Interest: The author declares no conflict of interest. The founding sponsors had no role in the design of the study; in the collection, analyses, or interpretation of data; in the writing of the manuscript, or in the decision to publish the results.

\section{References}

Agüero, Felipe. 2005. The Promotion of Corporate Social Responsibility in Latin America. In Philanthropy and Social Change in Latin America. Edited by Cynthia Sanborn and Felipe Portocarrero. Cambridge: Harvard University Press, pp. 103-34.

Aguilera, Manuel. 1975. Desnacionalización de la economía Mexicana. Mexico City: Fondo de Cultura Economica.

Amcham. 1974a. Public Affairs Involvement (Special Section). Mexican-American Review 44, pp. $4-14$.

Amcham. 1974b. Seminar Explores the Why and How of Public Service Projects. MexicanAmerican Review 42, pp. 6-10.

Amcham. 1977. Special Historical Report. Mexican-American Review 45: 11.

Andonova, Veneta, and Losada-Otálora Mauricio. 2018. Multilatinas. Strategies for Internationalisation. Cambridge: Cambridge University Press.

Ardavín, Bernardo. 1987. Valores de la sociedad actual. In Foro Nacional Empresa y Sociedad (Crisis y Soluciones). San Pedro Garza García: USEM Monterrey, pp. 1-12.

68 See for a historical perspective (Osterhammel and Petersson 2003). For multidisciplinary, especially political-science perspectives, see (Helleiner and Pickel 2005; Lechner and Boli 2015, esp. parts V and $\mathrm{XI}$ ).

69 Not in the context of the Agenda 2030, but of globalisation, this idea can be considered as "political" CSR, see (Scherer and Palazzo 2011). 
Bair, Jennifer. 2009. Taking Aim at the New International Economic Order. In The Road from Mont Pèlerin. The Making of the Neoliberal Thought Collective. Edited by Philip Mirowski and Dieter Plehwe. Cambridge: Harvard University Press, pp. 347-85.

Basáñez, Miguel. 1991. La lucha por la Hegemonía en México, 1968-1990, 9th ed. Mexico City: Siglo Veintiuno Editores.

Baumer, Jean-Max, and Albrecht von Gleich. 1982. Transnational Corporations in Latin America. Interactions between Nation States and Transnational Corporations: The Case of German and Swiss Firms operating in Colombia, Brazil and Mexico. Diessenhofen: Rüegger.

Bensusán, Graciela, and Jorge Carrillo. 2017. Measurement of the Employment and Labour-Related Impacts of MNEs in Mexico. An Analysis of Two Different Methodologies. Geneva: ILO.

Bensusán, Graciela, Jorge Carrillo, and Nelson Florez. 2018. Employment in Multinational Enterprises in Mexico. Analysis of the Economic Census. Geneva: ILO.

Berghoff, Hartmut. 2004. Die Zähmung des entfesselten Prometheus? Die Generierung von Vertrauenskapital und die Konstruktion des Marktes im Industrialisierungs- und Globalisierungsprozess. In Wirtschaftsgeschichte als Kulturgeschichte. Dimensionen eines Perspektivenwechsels. Edited by Hartmut Berghoff and Jakob Vogel. Frankfurt am Main: Campus Verlag, pp. 143-68.

Berghoff, Harmut, and Jakob Vogel. 2004. Wirtschaftsgeschichte als Kulturgeschichte. Dimensionen eines Perspektivenwechsels. Frankfurt am Main: Campus Verlag.

Bernal, Victor Manuel. 1976. El impacto de las Empresas Multinacionales en el Empleo y Los Ingresos. El caso de México. Geneva: ILO.

Bertolami, Silvio. 1983. Halbgötter, Giftkriege und Kondensmilch. Schweizer Agro-Firmen in der Dritten Welt. Basel: Z-Verlag, pp. 69-115.

Bielschowsky, Ricardo A., and Giovanni Stumpo. 1995. Empresas transnacionales y cambios estructurales en la industria de Argentina, Brasil, Chile y México. Revista de la Cepal 55: 139-64. [CrossRef]

Bonazzi, Giuseppe. 2014. Geschichte des organisatorischen Denkens. Wiesbaden: Springer.

Bonfil, Guillermo. 1987. México profundo. Una civilización negada. Mexico City: Grijalbo.

Bürgi, Jürg, and Al Imfeld. 2004. Mehr geben, weniger nehmen. Geschichte der Schweizer Entwicklungspolitik und der Novartis Stiftung für Nachhaltige Entwicklung. Zürich: Orell Füssli.

Burke, Roland. 2012. Some Rights Are More Equal than Others: The Third World and the Transformation of Economic and Social Rights. Humanity 3, pp. 427-48. [CrossRef]

Cadestin, Charles, Julien Gourdon, and Przemyslaw Kowalski. 2016. Participation in Global Value Chains in Latin America. OECD Trade Policy Papers. Paris: OECD.

Calidad Total. 1989. Perspectivas 1. Mexico City: Fundación Mexicana para la Calidad Total.

Calidad Total. 1990. Casos 3. Mexico City: Fundación Mexicana para la Calidad Total.

Calidad Total. 1991. Monografías 4-7. Mexico City: Fundación Mexicana para la Calidad Total. 
Arriola, Carlos. 1976. Los grupos empresariales frente al Estado (1973-1975). In Las fronteras del control del Estado mexicano. Mexico City: Colegio de Mexico, Centro de Estudios Internacionales.

Carrillo, Jorge, Alfredo Hualde, and Daniel Villavicencio. 2012a. Empresas y su entorno. El debate de la innovación. In Dilemas de la innovación en México: Dinámicas sectoriales, territoriales e institucionales. Edited by Jorge Carrillo, Alfredo Hualde and Daniel Villavicencio. Tijuana: El Colegio de la Frontera Norte, pp. 9-26.

Carrillo, Jorge, Redi Gomis, and Ismael Plascencia. 2012b. Multinacionales en México y su participación en la cadena global de valor. In Dilemas de la innovación en México: Dinámicas sectoriales, territoriales e institucionales. Edited by Jorge Carrillo, Alfredo Hualde and Daniel Villavicencio. Tijuana: El Colegio de la Frontera Norte, pp. 73-108.

Castillo Peraza, Carlos. 1999. De la globalización a la mundialización. In Revista USEM. Mexico: Confederación USEM, p. 229.

CEMEFI. 2016. RSE en México: la experiencia del CEMEFI, draft, ed. Mexico City: Centro Mexicano para la Filantropía.

CEMEFI. 2007. Informe Annual 2007, ed. 2007. Mexico City: Centro Mexicano para la Filantropía. CEMEFI. 2006. Informe Annual 2006, ed. 2006. Mexico City: Centro Mexicano para la Filantropía. CEMEFI. 1996. Informe Anual 1995-1996, ed. 1996. Mexico City: Centro Mexicano para la Filantropía.

Cerutti, Mario. 2000. Propietarios, empresarios, y empresa en el norte de México: Monterrey de 1848 a la globalización. Mexico City: Siglo XXI.

Chandler, Alfred D., and Bruce Mazlish. 2005. Leviathans. Multinational Corporations and the New Global History. Cambridge: Harvard University.

Chapoy Bonifaz, Alma. 1975. Empresas multinacionales: Instrumento del imperialismo. Mexico City: Ediciones El Caballito.

Concamin. 1994. Propuesta para la formulación del Plan Nacional de Desarrollo 1995-2000. México: Confederación de Cámaras Industriales de los Estados Unidos Mexicanos.

Concamin. 2000. Política Industrial 2000-2006. Mexico City: Confederación de Cámaras Industriales de los Estados Unidos Mexicanos.

Confederación USEM, ed. 1993. La empresa altamente productiva y plenamente humana. Mexico City: Editores Asociados Mexicanos and Unión Social de Empresarios de México.

de la Garza, Enrique, ed. 1999. Estrategias de modernización empresarial en México, flexibilidad y control sobre el proceso de trabajo. Mexico City: Friedrich Ebert Stiftung.

Dequech, David. 2003. Cognitive and Cultural Embeddedness: Combining Institutional Economics and Economic Sociology. Journal of Economic Issues 37, pp. 461-70. [CrossRef]

Diekmann, Andreas. 2014. Empirische Sozialforschung. Grundlagen, Methoden, Anwendungen, 9th ed. Reinbek bei Hamburg: Rowohlt.

Djelic, Marie-Laure, and Kerstin Sahlin-Andersson. 2006. Transnational Governance. Institutional Dynamics of Regulation. Cambridge: Cambridge University Press. 
Dunning, John H., and Sarianna Lundan. 2008. Multinational Enterprises and the Global Economy. Cheltenham: Edward Elgar.

Dussel Peters, Enrique. 2000. Polarizing Mexico. The Impact of Liberalization Strategy. Boulder: Lynne Rienner Publishers.

Dussel Peters, Enrique. 2003. Industrial Policy, Regional Trends, and Structural Change in Mexico's Manufacturing Sector. In Confronting Development. Assessing Mexico's Economic and Social Policy Challenges. Edited by Kevin J. Middlebrook and Eduardo Zepeda. San Diego: Stanford University Press, pp. 241-74.

El Universal. 2018. "El objetivo, continuar haciendo inversiones": Novartis México. Mexico City. Available online: eluniversal.com.mx/cartera/negocios/el-objetivo-continuarhaciendo-inversiones-novartis-mexico (accessed on 10 October 2019).

Fajnzylber, Fernando, and Trinidad Martínez Tarrago Tarrago. 1976. Las empresas transnacionales. Expansión a nivel mundial y proyección en la industria mexicana. Mexico City: Fondo de Cultura Económica.

Farias Arizpe, Jorge. 1985. Conclusiones del Foro. In Foro del empleo productivo, Memoria. San Pedro Garza García: USEM Monterrey.

Fernández, Rosa Ma. 1995. Las fundaciones norteamericanas y las instituciones no lucrativas en México. Mexico City: Centro Mexicano para la Filantropía.

Flores, Oscar. 2000. Monterrey industrial 1890-2000. Monterrey: UDEM.

Folke Schuppert, Gunnar, and Michael Zürn. 2008. Governance in einer sich wandelnden Welt, Politische Vierteljahresschrift, Sonderheft. Baden-Baden: VS Verlag für Sozialwissenschaften, p. 41.

Gereffi, Gary. 2003. Mexico's Industrial Development: Climbing Ahead or Falling Behind in the World Economy? In Confronting Development. Assessing Mexico's Economic and Social Policy Challenges. Edited by Kevin J. Middlebrook and Eduardo Zepeda. San Diego: Stanford Stanford University Press, pp. 195-240.

Gereffi, Gary, John Humphrey, and Timothy Sturgeon. 2005. The Governance of Global Value Chains. Review of International Political Economy 12, pp. 78-104. [CrossRef]

Gertschen, Alex. 2013. Klassenfeinde-Branchenpartner? Unternehmer und Gewerkschaft der westdeutschen Textilindustrie vor der Herausforderung der Internationalisierung 1949-1979. Baden-Baden: Nomos.

Gertschen, Alex. 2017. Katholische Soziallehre, multinationale Konzerne und staatliche (Un-) Sicherheit: Der Verantwortungsdiskurs der Unternehmer in Mexiko (1960er-1980er Jahre). Vierteljahrschrift für Sozial- und Wirtschaftsgeschichte 104: 525-59.

Gertschen, Alex. 2019. Multinationals' Changing Power and Legitimacy in the Global North and South: The Emergence and Change of Nestlés and Ciba-Geigy's CSR Communication in Switzerland and Mexico (1970s-1990s). Working Paper. Bern: Universität Bern, Center for Global Studies.

Giral, José. 1991. Cultura de efectividad. Mexico City: Instituto de Efectividad Xabre. 
Giral, José. 1993. Cultura de efectividad, 2nd ed. Mexico City: México Grupo Editorial Iberoamérica.

Giral, José, Antonio Eroles, Vladimir Estivill, Luis Lapuente, and Georgina Viesca. 1999. Manual de Gestión Empresarial. Programa de Desarrollo Empresarial de la Fundación Mexicana para la Calidad Total. Mexico City: Centro Mexicano de Gestión Empresarial.

Giral, José, Antonio Eroles, Vladimir Estivill, Luis Lapuente, and Georgina Viesca. 2000. Su empresa ¿de clase mundial? Havana: Panorama Editorial and Editorial Academia.

Giral, José, Antonio Eroles, Vladimir Estivill, Enrique García, Luis Larraza, and Georgina Viesca. 2002. Empresas competentes. Prácticas exitosas para el desarrollo de su empresa. Mexico City: Grupo Editorial Iberoamérica.

Giral, José, Antonio Eroles, Vladimir Estivill, Enrique García, Francisco Nieto, and Georgina Viesca. 2004. Más y mejores empleos. Propuestas para resolver el problema del desempleo en México con la participación de todos los sectores. Mexico City: Panorama Editorial.

Gordon Rapoport, Sara. 2008. Eficacia, confianza y legitimidad en el CEMEFI. In Acción colectiva y organización. Estudios sobre desempeño asociativo. Edited by Cristina Puga and Matilde Luna. Mexico City: Universidad Nacional Autónoma de México, pp. 61-94.

Grayson, David, and Jane Nelson. 2013. Corporate Responsibility Coalitions: The Past, Present, and Future of Alliances for Sustainable Capitalism. Stanford: Stanford University Press.

Gutiérrez, Julio. 1991. La calidad total. In Los empresarios y la modernización económica de México, Secretaría de Comercio y Fomento Industrial. Mexico City: M.A. Porrúa, pp. 257-68.

Gutiérrez, Mario. 1992. Administrar la calidad. Conceptos administrativos del control total de calidad. Mexico City: Centro de Calidad ITESM.

Hajduk, Thomas. 2013. A Code to Bind Them All. The Multinational Dilemma and the Endeavour for an International Code of Conduct. In Multinationale Unternehmen und Institutionen im Wandel-Herausforderungen für Wirtschaft, Recht und Gesellschaft. Edited by Sandra Brändli, Roman Schister and Aurelia Tamò. Bern: Stämpfli Verlag, pp. 311-39.

Harrisson, Pierre. 1982. L'empire Nestlé. Faits et méfaits d'une transnationale en Amérique Latine. Paris: Favre.

Helleiner, Eric, and Andreas Pickel. 2005. Economic Nationalism in a Globalizing World. Ithaca and London: Cornell University Press.

Hoshino, Taeko. 2013. Multinationalization Strategy of Mexican Family Business. In Family Multinationals. Entrepreneurship, Governance, and Pathways to Internationalization. Edited by Christina Lubinski, Jeffrey Fear and Paloma Fernández Pérez. New York and London: Routledge, pp. 117-32.

Humphrey, John, Yveline Leclerc, and Mario Sergio Salerno, eds. 2000. Global Strategies and Local Realities. The Auto Industry in Emerging Markets. Basingstoke: Macmillan.

Iffland, Charles, and Antoine Galland. 1978. Les investissements industriels suisses au Mexique. Lausanne: Centre de recherches européennes. 
Jones, Geoffrey. 2005. Multinationals and Global Capitalism from the 19th to the 21st Century. Oxford: Oxford Scholarship Online.

Kalt, Monika. 2009. “Nestlé tötet Babys!” Tötet Nestlé Babys? In 1968-1978: ein bewegtes Jahrzehnt in der Schweiz. Edited by Janick Marina Schaufelbuehl. Zürich: Chronos, pp. 183-94.

Kalt, Monika. 2010. Tiersmondismus in der Schweiz der 1960er und 1970er Jahre. Bern: Peter Lang AG, pp. 400-90.

König, Mario. 2016. Chemie und Pharma in Basel. In Besichtigung einer Weltindustrie-1856 bis 2016. Edited by Georg Kreis and Beat von Wartburg. Basel: Christoph Merian Verlag, vol. 1.

Krook, Ingvar J-son. 1976. Host Country Control of Foreign Investment. With Special Reference to Mexico and the Andean Group. Geneva: Council of Foreign Relations.

Kuhn, Konrad J. 2009. "Der Kampf der Entrechteten dort ist unser Kampf hier!". Entwicklungspolitische Solidarität und internationale Solidarität in der Schweiz. In 1968-1978. Ein bewegtes Jahrzehnt in der Schweiz. Edited by Janick Marina Schaufelbuehl. Zürich: Chronos, pp. 113-24.

Kuhn, Konrad J. 2012. Im Kampf gegen das "heimliche Imperium": Entwicklungspolitik und postkoloniale Kritik in der Schweiz seit 1970. In Postkoloniale Schweiz. Formen und Folgen eines Kolonialismus ohne Kolonien. Edited by Patricia Purtschert, Barbara Lüthi and Francesa Falk. Bielefeld: Chronos, pp. 267-87.

Laboucheix, Vincent. 1992. Tratado de la Calidad Total. Madrid: CDN, vol. 1.

Lechner, Frank, and John Boli. 2015. The Globalization Reader. Malden: John Wiley \& Sons, Ltd. Lessard, Donald R., and Rafael Lucea. 2009. Mexican Multinationals: Insights from Cemex. In Emerging Multinationals in Emerging Countries. Edited by Ravi Ramamurti and Jitendra Singh. Cambridge: Cambridge University Press, pp. 280-311.

Loretta, Frank B. 1973. It's Time to Tell it Like it is. Mexican-American Review 41, pp. 13-19.

Los empresarios y la modernización económica de México, Secretaría de Comercio y Fomental Industrial. 1991. Mexico City: M.A. Porrúa.

Loza Macías, Manuel. 1998. La globalización, ¿promesa y peligro? Revista USEM 222, p. 1.

Luján Uranga, Beatríz Eugenia. 2011. Responsabilidad social laboral. In La responsabilidad social mexicana. Actores y temas. Edited by Jorge Pérez. Mexico City: Instituto Mora, pp. 87-104.

Luna, Matilda, and Ricardo Tirado. 1992. El Consejo Coordinador Empresarial. Una radiografía. Mexico City: Universidad Naciona Autónoma de México.

Matthies, Klaus. 1977. Transnationale Unternehmen in Mexiko. Hamburg: Verlag Weltarchiv.

Maurel, Chloé. 2011. OIT et responsabilité sociale des sociétés transnationales depuis 1970. In L'Organisation internationale du travail. Origine, développement, avenir. Edited by Isabelle Lespinet-Moret and Vincent Viet. Rennes: Presses universitaires de Rennes, pp. 179-92. 
Middlebrook, Kevin J., and Eduardo Zepeda, eds. 2003. Confronting Development. Assessing Mexico's Economic and Social Policy Challenges. San Diego: Sage Publications, Inc.

Milanés, Salvador. 1995. Los frutos del neoliberalismo. Revista USEM 205, p. 1.

Milanés, Salvador. 1996. La globalización: fatalidad o espejismo. Revista USEM 209: 1.

Montavon, Rémy. 1979. The Role of Multinational Companies in Latin America. A Case Study in Mexico. Farnborough: European Centre for Study and Information on Multinational Corporation.

Montavon, Rémy. 1994. Nestlé y sus compras de café: tres ejemplos de compras directas a los productores en México, en Filipinas y en Tailandia. Vevey: Nestlé SA.

Moreno, Julio. 2003. Yankee, Don't Go Home! Mexican Nationalism, American Business Culture, and the Shaping of Modern Mexico, 1920-1950. Chapel Hill: University of North Carolina Press.

Moreno-Brid, Juan Carlos, and Jaime Ros. 2009. Development and growth in the Mexican economy: A historical perspective. Oxford: Oxford University Press.

Moreno-Brid, Juan Carlos, Juan Ernesto Pardinas Carpizo, and Jaime Ros Bosch. 2009. Economic development and social policies in Mexico. Economy and Society Boycott 38: 154-76. [CrossRef]

Mortimore, Michael. 2006. Globalización y empresas transnacionales: ¿Oportunidades para el Desarrollo? Santiago de Chile: Naciones Unidas/CEPAL.

Münch Galindo. 1992. Lourdes: Más allá de la excelencia y de la calidad total. Mexico City: Editorial Trillas.

Nestlé. 2018. Nestlé México logra el primer lugar del ranking Súper Empresas 2018, Nestlé press release. Mexico City. Available online: nestle.com.mx/media/pressreleases/nestl-mxicologra-el-primer-lugar-del-ranking-sper-empresas-2018 (accessed on 10 October 2019).

Newfarmer, Richard S., and Willard Fritz Mueller. 1975. Multinational Corporations in Brazil and Mexico: Structural Sources of Economic and Non-Economic Power, Report to the Subcommittee on Multinational Corporations, Committee on Foreign Relations. Washington: US Congress.

Obertreis, Julia, ed. 2012. Oral History. Stuttgart: Franz Steiner Verlag.

O'Brien, Thomas. 1999. The Century of US Capitalism in Latin America. Albuquerque: University of New Mexico Press.

O'Toole, Gavin. 2010. The Reinvention of Mexico. Liverpool: Liverpool University Press.

OECD. 2009. OECD Reviews of Innovation Policy: Mexico. Paris: OECD.

OECD. 2019. Mexico City: OECD Economic Surveys, Paris. Available online: oecd.org/ economy/surveys/Mexico-2019-OECD-economic-survey-overview.pdf (accessed on 10 October 2019).

Oliveiro, Vernie. 2010. The United States, Multinational Enterprises, and the Politics of Globalization. In The Shock of the Global. The 1970s in Perspective. Edited by Niall Ferguson. Cambridge: Belknap Press of Harvard University Press, pp. 143-55.

Osterhammel, Jürgen, and Niels P. Petersson. 2003. Globalization. A Short History. Princeton: Princeton University Press. 
Peón Escalante, Joaquín. 1991. El Premio Nacional de Calidad como acelerador del cambio cultural en México. In Calidad Total. Monografías 4. Mexico City: Fundación Mexicana para la Calidad Total, pp. 1, 2.

Pitteloud, Sabine. 2019. "Les invisibles Deviennent Visibles": Le role Politique des Multinationals et les Débats sur L'internationalisation en Suisse (1942-1993). Ph.D. thesis, Université de Genève, Geneva, Switzerland.

Pozas, María de los Ángeles. 1994. Modernización de la industria y relaciones de trabajo. Mexico City: Representación en México de la Fundación Friedrich Ebert.

Pozas, María de los Ángeles. 2002. Estrategia internacional de la gran empresa mexicana en la década de los noventa. Mexico City: El Colegio de México.

Pozas, María de los Ángeles. 2006. Tecnología y desarrollo en las cadenas productivas de las grandes empresas en México, In Estructura y dinámica de la gran empresa en México: cinco estudios sobre su realidad reciente. Edited by IDEM. Mexico City: El Colegio de México, pp. 71-110.

Pries, Ludger. 2000. Entre el corporativismo productivista y la participación de los trabajadores. Globalización y relaciones industriales en la industria automotríz mexicana. Mexico City: Miguel Ángel Porrúa.

Propuestas del sector privado 1994-2000, Canacintra, Coparmex and Concanaco. 1994. Mexico City: Instituto de Proposiciones Estratégicas.

Revista USEM. 2001. 2001 (Sep-Oct), n. 243. Mexico City: Union Social de Empresarios de México.

Revista USEM. 1997. 1997 (Nov-Dec), n. 220. Mexico City: Union Social de Empresarios de México.

Ros, Jaime. 2008. La desaceleración del crecimiento económico en México desde 1982. El Trimestre Económico 299: 537-60. [CrossRef]

Rosenberg, Emily S. 1982. Spreading the American Dream. American Economic and Cultural Expansion, 1890-1945. New York: Hill and Wang.

Sada, Andrés Marcelo. 1978. El hombre, alma de la empresa. Revista USEM 48, pp. 2-4.

Sada, Andrés Marcelo. 1980. Productividad y Calidad de Vida de Trabajo. Revista USEM 59, pp. 16-18.

Sada, Andrés Marcelo. 1989. Análisis práctico de la función social de la empresa moderna, Memoria. In Foro Nacional Balance Social. Mexico City: Confederación USEM.

Santiso, Javier. 2013. The Decade of the Multilatinas. Cambridge: Cambridge University Press.

Sasson, Tehila. 2016. Milking the Third World? Humanitarianism, Capitalism, and the Moral Economy of the Nestlé Boycott. American Historical Review 121, pp. 1196-224. [CrossRef]

Scherer, Andreas Georg, and Guido Palazzo. 2011. A New Political Role of Business in a Globalized World. A Review and Research Agenda. Journal of Management Studies 48, pp. 899-931. [CrossRef] 
Schmid, Michael. 2008. Soziale Einbettung und ökonomisches Handeln. Mark Granovetters Beitrag zu einer soziologischen Theorie des Unternehmens. In Die Gesellschaft der Unternehmen-die Unternehmen der Gesellschaft. Gesellschaftstheoretische Zugänge zum Wirtschaftsgeschehen. Edited by Andrea Maurer and Uwe Schimank. Wiesbaden: Springer, pp. 73-103.

Schmidt, Samuel. 1991. The Deterioration of the Mexican Presidency: The Years of Luis Echeverría. Tucson: University of Arizona Press.

Schneider, Ben Ross. 2009. Hierarchical Market Economies and Varieties of Capitalism in Latin America. Journal of Latin American Studies 41, pp. 553-75. [CrossRef]

Schneidewind, Uwe. 2018. Die Grosse Transformation. Eine Einführung in die Kunst gesellschaftlichen Wandels. Frankfurt am Main: Campus Verlag.

Sepúlveda, Bernardo, Olga Pellicer de Brody, and Lorenzo Meyer. 1974. Las empresas transnacionales en México. Mexico City: El Colegio de México.

Servan-Schreiber, Jean-Jacques. 1967. Le défi americain. Paris: Denoel.

Sethi, S. Prakash. 1994. Multinational corporations and the impact of public advocacy on corporate strategy. Nestlé and the infant formula controversy. Dordrecht: Springer.

Sigmund, Paul E. 1980. Multinationals in Latin America. The Politics of Nationalization. Madison: University of Wisconsin Press.

Soberón, Guillermo, Cuauhtémoc Valdés Olmedo, and Concepción Hernández. 1995. La responsabilidad social de las empresas. Mexico City: Fundación Mexicana para la Salud.

Tarin, Carlos G. 1990. El nuevo concepto de calidad total. Revista USEM 155: 8-12.

Urquidi, Víctor L. 2005. Otro siglo perdido. Las políticas de desarrollo en América Latina (1930-2005). Mexico City: Fondo de la Cultura Económica.

Valdés, Chabre Alberto. 1976. Experiencias de participación en países europeos. Revista USEM 36: 10-15.

Vernon, Raymond. 1963. The Dilemma of Mexico's Development. The Roles of the Private and the Public Sectors. Cambridge: Cambridge University Press.

Vernon, Raymond. 1964. Public Policy and Private Enterprise in Mexico. Boston: Harvard University Press.

Vernon, Raymond. 1971. Sovereignty at Bay: The Multinational Spread of US Enterprises. London: Wiley Periodicals, Inc.

Villavicencio, Daniel. 2012. Incentivos a la innovación en México: entre políticas y dinámicas sectoriales. In Dilemas de la innovación en México: Dinámicas sectoriales, territoriales e institucionales. Edited by Jorge Carrillo, Alfredo Hualde and Daniel Villavicencio. Tijuana: El Colegio de la Frontera Norte, pp. 27-72.

Viñuales, Jorge E., and Magnus Jesko Langer. 2012. Foreign Investment in Latin America: Between Love and Hatred. In Latin America 1810-2010. Dreams and Legacies. Edited by Claude Auroi and Aline Helg. London: Imperial College Press, pp. 319-58. 
Wilkinson, Adrian, and Hugh Willmott. 1995. Making Quality Critical. New Perspectives on Organizational Change. London: Cengage Learning Ernea.

Witzel, Morgen. 2012. A History of Management Thought. Oxon: Routledge.

Zeller, Christian. 2001. Globalisierungsstrategien. Der Weg von Novartis. Berlin: Springer.

Zepeda, Eduardo, and David Castro Lugo. 1999. Reestructuración económica y empleo en México. Saltillo: Universidad Autónoma de Coahuila.

(C) 2021 by the author. Licensee MDPI, Basel, Switzerland. This article is an open access article distributed under the terms and conditions of the Creative Commons Attribution (CC BY) license (http://creativecommons.org/licenses/by/4.0/). 

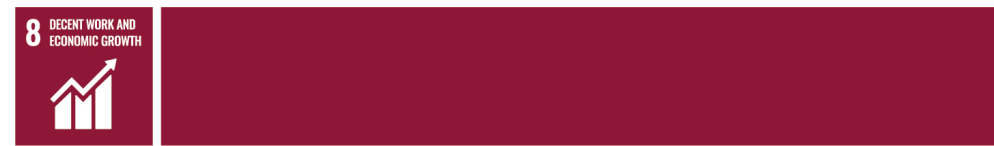

\title{
Challenges for the Host Society-Human Trafficking, Slavery and Abuse in the Work Context
}

\author{
Maria Elo and Arla Juntunen
}

\section{Introduction}

The United Nations Sustainable Development Goal 8 (SDG 8)—decent work and economic growth-is central to the human rights and wellbeing of individuals who are at the productive age. In the globalized world, the mobile labor force has become an issue beyond being an economic production factor. At the same time, this mobility of people has introduced new challenges in host societies in developed and developing countries that are receiving migrants. Emphasis on the social and economic integration of migrants has dominated discussions about the implications of human mobility. Yet, these discussions have remained too simplistic to address the multifaceted nature of the phenomenon. It seems that civil society in the host countries and institutions does not adequately understand and discuss the challenging implications of migration. Components of decent work-employment, social protection, workers' rights, and social dialogue-may be lacking (Ghai 2008). For example, regarding ethnic businesses and possible side-effects such as human trafficking, slavery, or work-related abuse, those tend to remain in the shadows. Even though the host society as a whole has possibly dealt with these problems historically, and enjoys a high level of development, the modern civil society and its institutions do not necessarily perceive the existence of these challenges re-entering the local context.

Partly due to the limited research and the novelty of the phenomenon, there is little awareness and few systemic competencies to effectively address the challenges of human trafficking and work-related abuse in host societies once the problems begin to emerge. The learning that needs to happen for such systemic improvements has been discussed in sociology, but less so with regard to managing the updates in institutional structures and processes (e.g., Potrafke 2016). However, preventive, rather than reactive, governance is considered more efficient to tackle the challenges. Preventive governance ex ante hinders the emergence of an illicit practice, like abusive labor practices, as it has created effective procedures to recognize and correct problems, 
if or when they arise. Reactive governance is acting ex post on an illicit practice that has already started its rooting process.

We use the term foreign worker to describe immigrants, asylum seekers, and migrant workers in this article. This is because work is the focal concern in terms of regulation, and it is used to determine categorization for the type of migrant; work differentiates, for example, categories such as marriage or student migrants who do not enter the host country with the sole purpose of work (e.g., Heikkilä and Rauhut 2015). The "foreign" refers to the migrant origin and status of the worker. Foreign workers here are interchangeably referred to as migrant workers or migrants. ${ }^{1}$ The term migrant is often mixed with other terms or used interchangeably (e.g., Vore 2015); migrant is a more inclusive term that includes e.g., refugees, temporary workers, marriage migrants, and those moving for economic reasons. Vore (2015) highlights the term migrant when referring to people who are still on the move or may wish to return home one day, i.e., are perhaps not permanently immigrating. The term "immigrant" typically refers to migrants who have moved to a foreign country with the intention of settling there-with a permanent residence. Following the newest definition by the International Organization for Migration, we use the term migrant as "a person who moves away from his or her place of usual residence, whether within a country or across an international border, temporarily or permanently, and for a variety of reasons" (IOM 2019, p. 130), since this is well in line with the need to address migration in the country of origin and start the preventive and protective measures regarding exploitation already there.

Newly arrived foreign workers are most often not knowledgeable about the host society and its institutional system and unaware of the rights and obligations they have regarding employment. Similarly, as with other entrants (such as firms and entrepreneurs) coming to a new context, they are liable not only for being foreign but also due to their newness in the context and their lack of connectedness (e.g., Johanson and Vahlne 2009). These liabilities translate into vulnerability and hazards for the entrant (Denk et al. 2012).

Those foreign workers who migrate following their family, relatives, or friends receive information that is not necessarily correct or adequate; it may offer a very informal and limited view of the host country's labor system. Typically, the highly

1 The person is a migrant because of having crossed a border, but their work status differs; hence, in some phases, we only refer to the person as a migrant for reasons of simplicity. 
skilled corporate expatriates receive formal onboarding and information on the destination, but this is less so for those arriving via social connections.

Migrants and foreign workers bring with them different practices and behaviors related to work and these often blend in with the existing practices of the host society. This may happen irrespective of whether or not these practices are legal in the host country. As a result, illicit labor-related practices diffuse into the host country context. This is partly because the migrant workers do not always know what is illegal or because they are dependent on their employers and, thus, cannot protect themselves, and partly because the employers may not know or care if they are using illegal or abusive labor practices (Martin 2012). The ethnic enclaves and business networks may not operate in a legitimate manner for diverse reasons, such as previously dominant practices, profit making, or crime. Furthermore, the idea of a "safe corridor" of entry into a new country's labor market by following co-ethnics ${ }^{2}$ or relatives abroad and working in their businesses is alluring and social tie-driven for new immigrants dreaming of a better future without poverty. This safe corridor mechanism provides a socially connected and often even dependent human resource base. Social ties in ethnic economies are central and their meaning in employment and business is notable (Wahlbeck 2007). Ethnic economies describe migrant businesses with co-ethnic employees, pointing out a migrant minority business and employment sector that coexists with the general economy (see more in Light et al. 1994). It is argued that the entrepreneurs in the ethnic enclave economy earn higher returns while their employees earn lower returns than they would in the general labor market (Sanders and Nee 1987). Ethnic enclave economies represent a part of a dual labor market, a labor market with inferior/secondary status (Light et al. 1994). Such ethnocultural settings can develop shadow economies (Grzymała-Kazłowska 2005) as their social and ethnocultural systems and norms continue to exist in the host economy and do not necessarily integrate into the host society.

As a result, this context in the host country can be deceptive for the newcomers as they do not speak the language well, or not at all. Migrant workers often do not understand the host country's legal system or do not know the labor market practices

2 Co-ethnics are people who share common features of ethnic heritage; they may or may not have the same citizenship, but they do share other features, e.g., ancestors/family in the same country, language, religion, racial as well as other diasporic characteristics. Typically, we refer to co-ethnics when the people are abroad (e.g., in labor diaspora) and share important features with their co-ethnics that they do not share with the local people or other migrant populations. 
(cf. Light et al. 1994), and lack access to formal work-related information, especially if they enter the host country mainly through informal ethnic channels. Ethnic channels of entry refer to an entry with the help of family, relatives, and other weak tie-connections and other relational networks that do not involve labor organizations and other labor authorities (Wilson 1998). This makes them vulnerable to exploitation by co-ethnics or others who sense their vulnerability, which is an under-researched concern and a loophole in many governance systems ( $\mathrm{Li}$ 2017). There may be intentional economic strategies by e.g., a criminal network providing cheap labor to a sweatshop (e.g., Lan 2015), but there may also be partly unintentionally illicit strategies linked to employers' lack of knowledge on the labor market regulation and conditions, especially if the employer himself is from a different country of origin and faces numerous liabilities of foreignness as an entrepreneur (cf. Denk et al. 2012). Davitti (2010, p. 42) claimed that "Conflict-related child trafficking is particularly fluid in nature as it follows patterns of insecurity, instability and the collapse of law and order, which are characteristics of conflict and post-conflict countries." However, human trafficking is also a concern in Europe that is well documented. In both the Prato area of Italy, textile production, and in the ethnic food market of Finland, exploitative and abusive practices were found where non-European exploitative labor practices developed in an ethnic cluster despite the European institutional setting (Lan 2015; Teittinen 2020); such cases were found where cultural distance ${ }^{3}$ was notable, e.g., in the Nepalese ethnic restaurant business (Teittinen 2020). Regardless of the etiology or origin of these practices, they need to be addressed efficiently and in the early stages, as they undermine governance and its legitimacy in a particular enclave (e.g., Sanders and Nee 1987; Chen and Liukkunen 2019). So far, sociologists and migration scholars highlight the importance of turnaround management that addresses these negative formations, especially to restrict such institutions from developing and becoming deeply rooted in their contexts (Shihadeh and Barranco 2010; Bell and Machin 2013).

The purpose of this paper is to increase the understanding of decent work in the context of integrating migrants as employees and entrepreneurs while maintaining societal harmony. Empirically, this paper illustrates what kind of abusive practices around vulnerable migrants have emerged in a highly developed Nordic country and how institutions tackle them. We focus on Finland, which is a theoretically interesting context having one of the lowest corruption indexes in the world (Transparency International 2018) and a highly regulated labor market (ILO 2019). Finland is also

3 See more on cultural distance in (Triandis et al. 1988). 
a country with a long tradition of decent work and societal awareness of human rights. It serves well to explain the appearance of abusive labor market practices related to foreign workers as the country has a relatively young history in terms of receiving migrant workers (e.g., Elo 2017). This era started only when the first Somalian refugees arrived in Finland in the 1990s, making Finland young in the receiving country context (e.g., Heikkilä 2017). Today, the country hosts migrant populations from diverse backgrounds. It is one of the European Union countries that received notable inflows of migrants from Syria, Iraq, and other countries during the so-called refugee crises in 2015. As this is a recent phenomenon, it means that there are no dominant practices or established governance traditions in the Finnish labor market regarding labor migrants. Mechanisms to effectively monitor large or unexpected immigration flows are first being created facing the new pressures on the EU external borders. This is a reason why the governance system went through a real-life stress-test during the migration crises and faced suboptimal conditions. The systemic resources of the state were consumed mainly to cope with the inflow of migrants, and not to govern or to develop entrepreneurial or business practices or guidance for ethnic labor markets.

The recent developments underline the importance of the topic. The increasing cases of intra-ethnic exploitation bring up the need to re-address the concern that decent work conditions, ethics, and laws apply to everyone, including newcomers (Teittinen 2020). This negative development, i.e., diffusion of foreign illicit and abusive practices, needs the attention of the civil society and Finnish formal institutions, because it is a societal caveat influencing all (Kolodziej 1992). Local labor, labor protection, and work conditions have been central to governance concerns from very early on in Finland and the role of labor unions has traditionally been important in co-developing labor market regulations. Despite that, in the developed Nordic societies, the reintroduction of such "historical" or "foreign" issues has been happening under the radar. These practices have emerged within minority populations that remain out of sight. Furthermore, it is a window of opportunity and a profitable strategy for those ethnic entrepreneurs to abuse co-ethnics, other migrants or relatives, since the entrepreneurs have enjoyed the fruits of that labor without paying the respective contributions and tariffs. Lack of attention and loopholes in legislation and regulation have left newcomers partly unprotected.

This paper addresses the need to develop societal, multi-level mechanisms for increasing awareness and formal institutional systems that may reduce and terminate these negative developments that have shaken the idea of worker protection and inclusion in the host society. The focus is on the migrant newcomers, e.g., foreign 
workers, as this is the most vulnerable group, but we recognize that such practices may influence any worker. This phenomenon of abuse is not a problem of developing countries or countries with weak institutions, as dramatic evidence from domestic workers' abuse has suggested (Chin 2003); it is a global challenge, shifting and changing its nature according to its context.

This discussion contributes to decent work on three levels: first, on the level of formal governance and institutional response; second, on the level of civil society acceptance vs. disapproval of the illegal, foreign practices ${ }^{4}$; thirdly, on the level of shutting down illicit and exploitative entrepreneurial opportunities. The paper is organized as a conceptual discussion; it starts with a review, presents findings related to the case of Finland and ends with a discussion and conclusion.

\section{Reviewing the Phenomenon and Its Landscape}

\subsection{Background and Challenges in Finland}

The number of migrants and refugees has grown due to diverse global conflicts and threats. These are caused, e.g., by terrorism, such as ISIS in the Middle East, natural disasters, like earthquakes, tsunamis and hurricanes, or political turmoil and uncertainty, such as that in different Latin American countries or on the continent of Africa. These developments have introduced new challenges inside the host societies. There is a great urge to develop formal policies and suitable solutions to cope with global migration flows (Barnard et al. 2019). ${ }^{5}$ The recent migratory waves put pressure on countries receiving migrants and their institutional systems to absorb this additional labor force. Civil society and the already existing, established migrant populations and diasporas face challenges in absorbing the newcomers (Daley 2007; Kupferberg 2003). Extant diasporas often become scapegoats and feel threatened by the newcomers; hence, it is important to capture the micro-foundations of diaspora politics when making assumptions for related governance dynamics (Délano Alonso and Mylonas 2019).

Countries lacking experience in receiving migrants suffer from limited capability in governing the new migration-driven challenges in labor markets as they are

4 Foreign practices refer here to practices that are not known/habitual in the local population and society and have a foreign origin, i.e., are arriving to the context with and practiced by foreigners.

5 See e.g., the Special Issue "Migrants, Migration Policies, and International Business Research: Current Trends and New Directions" of the Journal of International Busines Policy, Volume 2, Issue 4, December 2019 by Guest Editors: Helena Barnard, David Deeds, Ram Mudambi, and Paul M. Vaaler: this should be included in the reference list. 
different from local governing challenges (see e.g., Heikkilä 2017). Finland also lacks adequate resources in terms of personnel that understand the ethnic backgrounds, and have foreign language competencies and the cultural understanding that is needed to tackle the issues (Finnish Border Guard 2014). This suggests that Finnish institutions face several challenges due to such developments.

However, the main challenge relates to the victims of these practices and the prevention thereof. The global elite migrants represent the most privileged entrant type, while asylum seekers and so-called "economic refugees" form the most vulnerable group of migrants needing protection. In this vulnerable group, those who do not qualify under formal refugee criteria or are paperless tend to seek work and livelihood from alternative sources, below the radar. The low-skilled migrants seeking a better life in foreign countries' labor markets have remained a heavily debated category of migrants, especially, regarding the formal entry pre-requisites, permit processes, length of stay, illicit entry practices, and the impact on the host society (e.g., Rivera-Batiz 1999). For example, in 2015, the flow of irregular migrants, particularly from Africa, the Middle East, and Asia, entering the EU reached unprecedented levels and has remained high after 2015, which has raised questions of governance. ${ }^{6}$

There are limited formal options for low-skilled migrants to enter the labor market beyond temporary project work or seasonal work visas in areas such as agriculture. On the other hand, the growing number of new immigrants, particularly asylum seekers and refugees, has challenged many host countries and their administrations in terms of monitoring, assessing, and integrating these incoming people. There are numerous institutions responsible for the post-entry processing of vulnerable migrants, addressing their role and place in the host society, which creates administrative difficulties. The placement after entry is particularly problematic for paperless migrants as they typically enter shadow labor markets (e.g., Hughes 2000). However, it is also a systemic issue and many shadow labor markets are largely socially accepted phenomena, for example, minor household work. Such dual economies are usually found in developing country contexts (Callebert 2014).

The limited resources of governance systems have partly allowed the emergence of illicit practices, the criminal exploitation of migrants, and irregular entrepreneurial

6 See more in https://ec.europa.eu/home-affairs/what-we-do/policies/irregular-migration-return-policy_ en (accessed on 12 April 2020). 
activities, which are not contributing as they should to the host economy (e.g., Vero 2018b). The inadequate capacity of governance to address the in-depth nature behind such foreign practices that are "imported", ${ }^{7}$ mainly by ethnic populations into the country and not affecting the mainstream Finnish people directly, is a fundamental and complicated problem (Callebert 2014). It is less perceived due to its "invisible" features (Haynes 2009).

These negative developments in labor-related practices particuarly include human trafficking, slavery, and abuse, all of which generate profits and benefits illicitly. These are categories of practices that are clearly illegal and not in line with SDG 8 . Hence, the problem does not arise from the lack of laws and regulations (e.g., Finlex 1959), but more from inadequate attention, a lack of competences, and missing resources to tackle such practices. As these hazards are of international and transnational nature, not inherently local, they are less perceived. Both the governance system and the civil society in Finland face a form of liability of foreignness, but from the receiving side, in addressing these concerns (Johanson and Vahlne 2009). It is institutionally challenging to adapt the governance (e.g., Teittinen 2020).

In prior research, the problems of irregular and illicit activities in ethnic enclaves and migrant networks have been thematized, and there is a danger of the emergence of subcultures that do not follow the host society's laws and the rules of the game (cf. North 1990; Ojo et al. 2013). It is apparent that without proper governance processes in place and a well-functioning support network, the vulnerable new migrants and refugees might face the risk of being mistreated, abused, and becoming victims or even criminals themselves (e.g., Kelly et al. 2005). Depending on the ratio of risk and profit received from such practices, it might also become a strategic option for entrepreneurs to continue such practices. If the host country is unable to govern them and maintain locally legitimate and acceptable practices in the overall society, these loopholes are soon identified, as the experiences from Italy indicate (Dugan and Edelstein 2013).

Increasing migration and globalization has challenged the functions and balances in the Finnish institutions and society. It is important to notice that it is the responsibility of the Finnish state to govern its territory and the practices within that

7 With "imported", we mean that these practices do not typically pre-exist as Finnish labor market practices; they are transplanted in Finland as foreign practices that are brought in and take place in ethnic populations. Hence, they are not transplanted in the visible mainstream society. Naturally, there are also classic forms of exploitation, such as prostitution-related human trafficking, that are not new, foreign, or transnational and take place in Finland among mainstream Finns. However, this study is focusing on the host country challenges and respective "imported"/transplanted developments. 
territory, regardless of the status of the people residing in Finland. Laws protecting workers are non-negotiable and apply to all members of the society. During recent decades, Finland has internationalized in terms of its population (see Figure 1). The refugee crisis in Europe during 2014-2015 brought 32,476 refugees from the Middle East to Finland according to the Immigration Department of the Ministry of the Interior (2016). This number is ten times more than the number of refugees in 2014 when just 3651 refugees arrived from the same area. Such notable developments in the society create pressures and demand administrative agility.

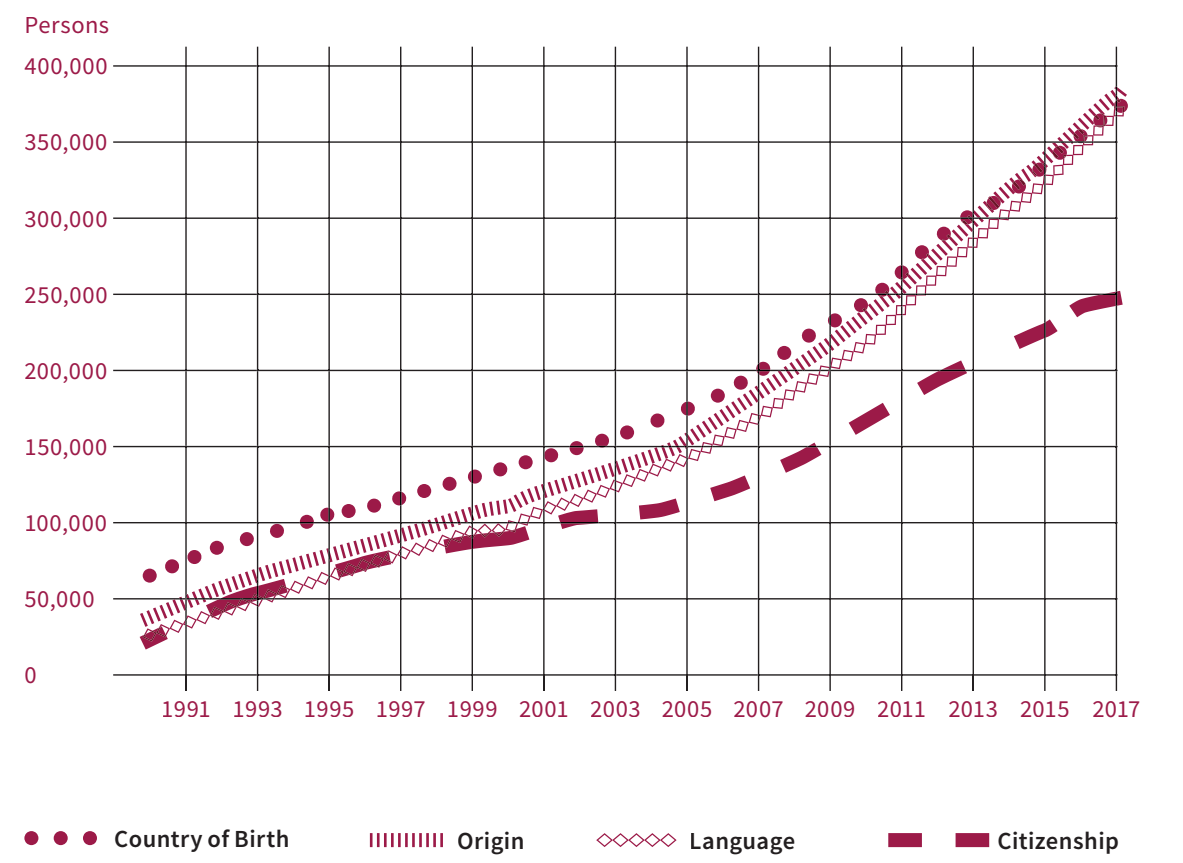

Figure 1. The development of foreign-origin people in Finland-foreign citizens, persons with foreign background, foreign-language speakers and persons born abroad, 1990-2017. Source: Statistics Finland/Population structure, (Statistics Finland 2019).

According to Statistics Finland, since the 1990s, the number of foreign-born residents has grown ten times, from $0.5 \%$ to, in $2017,5 \%$, largely due to the sudden immigration flow from Syria through Europe to Finland. The number of refugees in the European Union increased ten-fold during the years 2014-2015, during the so-called refugee crisis, without respective resource increases. In parallel, Finland 
is attracting qualified labor from abroad for various industries, e.g., construction and shipbuilding. Many labor migrants have a permanent residence in Finland, but temporary labor migrants also enter Finland for diverse occupations in agriculture and the service business. During recent decades, the Finnish labor market has also been able to attract highly skilled migrants from developed countries, e.g., for tech and other knowledge-based industries. These migrants are typically well informed and less vulnerable to abusive practices. The statistics show that most of the incoming flow settles to the southern part of Finland, where the capital and the largest cities in Finland are, causing the most pressure in this area (Heikkilä and Pikkarainen 2010).

The sudden increase in refugees stretched the capabilities of the Finnish administration, laws, and processes, and thus, spurred action and changes that were reported in the recent Ministry of the Interior's report (See Ministry of the Interior 2018). According to a recent Ministry of the Interior report (2018, p. 18), the "Immigration Unit" tripled during the year, from just over 70 to approximately 250 employees. The Finnish Immigration Service opened nine service points for the reception of applications and other customer services. Meanwhile, the number of personnel at the Asylum Unit decreased when the fixed-term employment contracts of the employees hired in 2016 to handle applications for asylum ended. However, the total number of personnel at the agency was on the rise again in 2017: it grew from 800 to 900 during the year and the upward trend continues. It has become evident that the institutional sector needs more agile resources to proactively and reactively respond to the challenges.

Moreover, the role of the Finnish Immigration Service as the authority responsible for asylum matters was strengthened by concentrating all permit matters in this office, including innovating new types of residence permits for seasonal workers, and growth and start-up entrepreneurs. In addition, the asylum procedure and other processes were updated, including the background information search from social networks. Processes relating to the integration of immigrants were also developed because the local communities had never seen a large number of foreigners enter in such a short period. Just the number has been a challenge, but also the different backgrounds, languages, religions, and traditions caused integration and interaction problems with local communities.

\subsection{Terms and Cases of Human Trafficking and Modern-Day Slavery in Finland}

It is important to discuss the nature of the terms related to the abuse of migrant workers in more detail and broaden the perspective that is needed to perceive and tackle the phenomenon. We start by presenting views from the extant literature that 
explain what these forms of illicit practices can be and how they are conceptualized. In statistics, they are not represented as clear-cut categories. ${ }^{8}$

Slavery is not only some colonial-era phenomenon; actually, it is a concern in many Western and emerging economy societies. This "modern slavery" can be defined as "a servitude broadly defined in a new study as forced and state-imposed labor, sexual servitude and forced marriage" and "it is a complex and often hidden crime that crosses borders, sectors, and jurisdictions" (Walk Free Foundation 2018). Slavery or its forms are almost commonly accepted practices in many countries, where labor regulations do not protect vulnerable groups, such as migrant women who are housekeepers, nannies, or other domestic workers. Several studies have pointed out the complicated nature of the responsibilities in governing, especially the transnational labor and the internationally active agencies and their practices (e.g., Hepple 2005, see also the International Labor Organization (ILO) website ${ }^{9}$ ). Hence, it is obvious that once the phenomenon of silently accepting slavery-like practices becomes systemic and part of everyday life, there is less interest in the society to govern it according to international laws and ethics (e.g., Jureidini 2010).

In Finland, slavery has traditionally represented a thing of the past, a historical practice that has happened in far-away countries. The first law against slavery in Finland was introduced in 1335. Finland joined the 1926 Slavery Convention in 1959 (Finlex 1959). Moreover, in Finnish criminal law codes, the exploitation of migrant labor refers to any form of illegal acts against persons of foreign origin who are working in Finland. These can be, for example, paying less than minimum wage to a migrant worker (Turtola 2018).

The Finnish civil society has not considered slavery or the peril of it as a possibility, and therefore, different forms of slavery have not been given serious attention. The Finnish labor unions, the employers, and the state have a long tradition of trade and work negotiations that form a specific governance style for addressing the labor markets and forming the respective regulations. These negotiations have generally covered diverse categories of workers, but not the slavery theme. The Finnish labor markets as formal institutions have not been discriminative in their nature due to the egalitarian culture and the Nordic approach, and this has

8 See more in http://www.stat.fi/til/rpk/2018/13/rpk_2018_13_2019-05-16_tie_001_en.html (accessed on 14 April 2020).

9 Specific publications are found here: https://www.ilo.org/global/publications/lang--en/index.htm (accessed on 14 April 2020). 
protected migrant workers in the eyes of the law before this recent migration wave (e.g., Ristikari 2011).

However, despite the governance and institutional structures that have long been functioning well, slavery has arrived in Finland. Vaarakallio (2013) interviewed Professor Kevin Bales about modern-day slavery and concluded in his article that "slaves in Finland have to work, for example, as sex slaves or slaves for domestic and agricultural work". In popular discussions and media, cases from very specific industries have been pointed out. For example, a slave-like status of the berry pickers arriving from southern East Asia has been pointed out. These migrants have a temporal work visa, but they bear the financial risk of profitability of their berry picking trip to Finland as their work is not compensated per hour but per result. They do not have an employment contract and they are seen as self-employed (e.g., Richards and Saastamoinen 2010).

It is difficult to draw clear boundaries based on the criteria that are used to describe different terms on exploitation. Human trafficking is a term that is rather inclusive and incorporates multiple activities. In the majority of OECD countries, there is a variety of terms used to describe human trafficking, including trafficking in persons and contemporary or modern-day slavery. The different terminology makes comparisons challenging. For streamlining and harmonizing legitimate practices across cultures and host countries, some generally accepted terms and clarity in the criteria are necessary. Similarly, research comparisons are needed. We found out that it is difficult to compare statistics of the work-based slavery or slavery in Finnish crime statistics because there is no umbrella term in the Finnish law for statistical purposes for all the different crimes related to modern-day slavery. In Finland, there are different criminal codes to tackle human trafficking and work-based slavery.

We present some cases of work-based slavery as a part of human trafficking and abuse to illustrate the diversity within the terms. The empirical materials in this study consist of cases that have been through the justice system in Finland under the label of human trafficking or abuse at work among migrant workers. The crime of extortionate work discrimination (Finlex Work-based discrimination code 47 (3)) refers to the exploitation of migrant workers due to their vulnerable situation, their dependence on the employer, or their lack of Finnish language or understanding of rights in Finland. The exploitation can include threats against migrant workers and even human trafficking (Crimes against Freedom 25 (3), 25 (3a)). The elements of codes 47 and 25 partially overlap with the criminal provision on human trafficking depending on the seriousness of the crime. 
Additionally, the industry context affects the interpretation and, in Finland, the restaurant sector has been one of the main areas of legal cases. Heima (2019) reported on workers' abuse in Nepalese restaurants: these workers were requested to work 16 -h days and the labor law regulations were not obeyed. Another abuse case of restaurant workers was in the city of Kuopio: Hamalainen (2018) wrote that the owner of two ethnic restaurants was sentenced to three cases of human trafficking. Recently, Finland has experienced its first "pizza-gate" of illicit business practices. ${ }^{10}$ The police generated a campaign to increase Finnish consumer awareness on pricing, work and tax-related practices, suggesting that in the independent fast food sector, especially the pizza business, if the price is lower than that what is considered appropriate for a business to operate on profit, then consumers should question the legitimacy of that price and offering and report it to police officials. This was the first formal campaign to raise awareness and to educate civil society on gray economy practices and increase broader societal audiences' awareness to combat practices that do not follow the appropriate schemes. This campaign received a lot of attention and was discussed from various perspectives, including multiple case calculations showing how the pricing is constructed when minimum salaries and all taxes are included. The counterargument took place mainly from the perspectives of migrant business owners who, as entrepreneurs, could not calculate a tariff salary for their work time to remain competitive in the food sector, and also from the new entrepreneur point of view, of offering special pricing to attract customers.

Typically, the HORECA (Hotel, Restaurant, Catering) business has a high degree of manual labor and is among the key employer categories of migrants. In addition, there are increasing numbers of ethnic restaurants and bars owned by migrants in Finland. Several prior studies pointed out that service businesses, like restaurants and bars, are typical entry-level businesses for migrant entrepreneurs (see, e.g., Waldinger et al. 1990 on ethnic restaurant businesses; Altinay and Altinay 2006 on catering). The type of work in this sector is often a subject of debates regarding the salaries and duties, and the respective criteria for assessing those regarding the work of less-vulnerable non-migrant employees. Hence, this sector is sensitive to exploitative practices due to its specific nature and characteristics of work.

Beyond HORECA businesses, various service businesses employ large numbers of migrants. For example, cleaning, building and maintenance, and other household

10 See more in https://www.bbc.com/news/blogs-news-from-elsewhere-34515639 (accessed on 1 December 2019). 
services do not necessarily require notable language skills and act often as the entry-level jobs for migrants. Pajunen (2014) reported that cleaning services are among the jobs where migrant workers have been abused by being offered "a full-time job" and given only part-time work. Additionally, there have been cases where workers have not been paid according to the collective bargain made between the employer's union. However, the migrant workers do not usually know about the unions and whom to contact.

The building sector has been at the epicenter of media attention. The foreignness of many of the companies, resulting in questionable employment and work practices, might be either unintentional ignorance or intent. There are numerous cases of exploitative or illicit practices in employing or compensating migrant or foreign workers in the construction business. "In Finland, the union representative of the Construction Union goes around the capital city to check out the construction sites for worker violations and abuse. He visits twenty construction sites per month. He finds about 30 work violations in a year." (Pajunen 2014), which means there were about $12.5 \%$ violations of all the sites visited.

Additionally, seasonal businesses in Finland, like berry picking, have had some work abuse or work violations reported. However, not all these cases are found legitimate. In 2014, Thai berry pickers went on strike and filed a lawsuit against their employer. They also involved the local embassy and the Thai diaspora in the discussion in Finland. The case was reviewed and the court decided they were incorrect in their claims (Rönty 2014; Karjalainen 2014). The Thai pickers had arrived on their own to be seasonal pickers; they were not hired or invited by the company involved. Due to bad weather, there were not enough berries to be picked, thus they did not get paid. The court decided that they were not eligible for wages or vacation pay (Rönty 2014). This case shows that migrant workers are becoming more aware of their rights when they are employed and are ready to fight for them.

Beyond formal legitimate work, there is the illegitimate side of work that concentrates on businesses mainly under the radar of the governance systems. Prostitution and dealing forbidden substances like drugs and prescription medication represent some such businesses. Prostitution is a highly profitable field of human trafficking and according to the Finnish Police and Statistics Finland, this is about a EUR 100 million business every year (Santtu 2019). Previously, the exploited workers were mainly vulnerable migrants from Eastern European or African countries. Prostitution has been typically linked to international or transnational organized crime and their networks. Moreover, unraveling these cases of international or transnational human trafficking cases can take years. A recent case of sex workers, 
human trafficking, and money laundering took place in several European Union countries. The investigation started in 2016 and ended with the capture of three Finnish suspects in Spain in 2019 (STT et al. 2019). The leaders of this prostitution and human trafficking ring lured young women into the world of prostitution by promising them a good income, whereas the reality was that the leaders pocketed most of the money themselves. This highlights that the victims are not necessarily from a developing country or particularly disadvantaged; instead, there is an increasing danger of transnational and smartly organized crime that builds on the resources of the developed countries. This same article suggests that online prostitution services seem to be easier to create and manage by the criminals, but harder to monitor, control, and takedown by the authorities. These technological resources and the transnational nature of the new exploitation and crime also highlights the danger of illicit practices diffusing and directly affecting the local non-migrant population. Besides the prostitution and the service business-related slavery, news reports show that there are also drug users that are forced to commit human trafficking crimes (Hannus 2018). These crimes can include organ or drug trafficking (Hannus 2018), which highlights the need to address these increasing dangers prudently and effectively. These practices need to be tackled to hinder their shift and influence from the criminal subcircles to the everyday civil society.

\subsection{Challenges of Governance and Civil Society in Finnish Business}

Another concern for governance is related to time and resources, not just the effectiveness of the governance per se. Lan (2015) points out that legislation alone is not efficient for de-rooting such phenomena. Governance needs to be linked to the time windows of the phenomenon. For example, solving a human trafficking case can take years. A recent conviction of a human trafficking case that started in 2013 and ended in 2016 involved an Indian pizzeria owner in the city of Vantaa and showed the length of the process.

The novel types of illicit practices are challenging on many levels; they generate additional needs for governance structures that monitor and also control the field of such practices more preventively. Illicit actions challenge the views and absorptive capacity of the civil society to deal with such practices and avoid societal divides, especially when they are perceived as being late. Such practices influence the overall perceptions of migrant workers, ethnic businesses, and ethnic enclaves (e.g., Dana 2007). Furthermore, the bad reputation that results from these cases easily transfers to other ethnic and migrant entrepreneurs who have nothing to do with 
such illicit practices. Legitimate entrepreneurs who follow laws and regulations have started to feel the negative implications in their businesses.

The negative brand transfer may take place without any actual reason or fact, just building in terms and categories such as "ethnic" or "restaurant" in the minds of consumers. As a result, the economic success and profitability of these businesses is negatively influenced. This may increase the pressure to develop new means for increasing profitability and further push illicit practices, even if they were previously not considered (e.g., Rath 2000). It is important to notice that many migrant businesses are the primary/sole livelihood generators for the migrant families, and, in several migrant communities and extended families, the responsibilities are far-reaching (Heinonen 2010). This suggests that the semantics employed in combating illicit practices and abuse are very sensitive and may turn against the legitimate migrant entrepreneurs if not carefully considered in communication and public debates. The official communication and related "grey economy" campaigns are also subject to be misused in the political discourse as they may fit various agendas that do not represent the formal governance views.

In addition to the fragile economic-entrepreneurial dynamics and political sensitivity that influence the balances in local civil society, there is a challenge related to the resource implications of governance that has both direct and indirect dimensions. Directly, if just one human trafficking case in Finland takes years to process, it will tie up resources from many officials, including police investigators and criminal prosecutors. Government resources are limited, hence, only those resources that are available will be allocated to these activities. Meanwhile, if the exploitative and illicit practices grow faster, the governance institutions will not be able to control the phenomenon and it will continue to diffuse. Indirectly, if the governance institutions do not succeed in curbing negative developments and the civil society begins to perceive and sense the implications of abusive practices more, the legitimacy of the institutions' actions will be questioned and the taxpayers will be less likely to have a constructive attitude towards increasing funds for something that does not seem to work. The ethnic and migrant entrepreneurs who follow good practices will face further pressures, and the public opinion will become more negatively loaded. This vicious circle is difficult to stop if it starts (Porter and Kramer 2019).

Simply the magnitude and pace of recent changes have set new demands for all layers of institutions in host countries in responding to the vulnerabilities. Many newcomers are not a priori trained and educated to know about the laws of the host country and its institutions. This creates a window of opportunity for illicit action. In the entry and integration process, there are transitions and liminal spaces of 
diverse vulnerabilities (e.g., Craig et al. 2015). These represent a potential disconnect between governance and practice and there is only limited experiential knowledge on closing this gap. However, such governance expertise and knowledge is essential for a sustainable integration and settlement process.

In international business and entrepreneurship, this home-host country discrepancy related to knowledge, experience, and resources has been addressed through several concepts and terms (e.g., Johanson and Vahlne 2009), but mainly from the firm or entrepreneurial perspective. Just like new firm entrants, new migrants face an unknown territory of work-life and business operations with hazards. The entry can be approached as a processual setting: pre-entry-, entry-, integration-, and further development/settlement phase. The receiving host societies need to take care that they update their administrative resources to address these new demands and developments before illicit practices start to emerge into a problem in all phases. Migrants are often conceptualized as the actors producing the crime, but in these areas of illicit practices, like abuse, human trafficking, and slavery, they are typically the unknowledgeable victims (e.g., Elo and Juntunen 2015). Those who act illicitly are often co-ethnics or other migrants, but also local, non-ethnic businesses, and this may build on proactive transnational mechanisms (e.g., Shelley 2010).

Examples from other countries, like Germany, suggest that due to the impermeable boundaries of some ethnic enclaves, clans, or even locational aspects, many of these practices do not appear on the labor markets or formal economy, but remain unseen, below the level of governance or civil society awareness for too long. ${ }^{11}$ This refers to the development of a parallel society. The reasons for such developments are manifold. One reason, on the institutional side, is the lack of competences and cultural insights, even language skills, to examine and govern enclave structures and economic functions. Lots of these crimes might go undetected due to the delimited official resources, and the resources are mainly not adequately "ethnic" to tackle these issues without extra effort (Peterson and Uhnoo 2012).

Another problem is the underdeveloped but necessary institutional capacity and holistic coordination, especially in new receiving countries or peripheral areas. As human trafficking can have many faces, it is sometimes difficult to identify and see it. In Finland, few agencies are involved, usually one at a time, in identifying and detecting human trafficking, and this has not been a noticeable phenomenon like in

11 See more in https://www.cicero.de/innenpolitik/brutale-familienbande/41463 (accessed on 2 December 2019). 
some other countries. According to Hannus (2018), the increasing total number of human trafficking has also led the Finnish Government, namely the police and border control, to update their system and train their employees on how to recognize victims of human trafficking. This training also includes cooperation between different officials and victim support groups.

It is vital to address the potential victims a priori and educate them before they become lured into exploitation. For example, U.S. embassies already give information against exploitative practices and abuse during the visa application process and the United States has diverse hotlines and non-governmental agencies to support victims of human trafficking. In new receiving countries like Finland, there are multiple institutions and government agencies involved in increasing awareness of work conditions and support systems. However, the victims usually lack language skills and do not have a support network (STT et al. 2019), the financial resources, or the travel documents to leave their situation. These victims and their family members in the country of origin could also be threatened with violence if the victim does not cooperate. Addressing this problem is a major challenge as the solution cannot be resolved by just one country. Transnational and collaborative governance is the key to solving such forms of organized crime that span country borders.

In recent years, the number of attempts of organized illegal immigration (including aggravated assault) has increased in Finland, which highlights the need for advanced responses. According to Laitinen et al. (2016, p. 25) "the suspects' nationality is usually from Iraq, Sweden, Syria, Somalia or Russia". The numbers have increased; in 2014 there were 385 and in 20152355 people illegally trafficked to Finland (Ibid.). Ucnikova (2014, p. 4) reported that "an estimate of USD 124 million is spent each year on modern slavery in the OECD countries". However, she also argues that there is no common terminology, and thus, it is difficult to obtain exact figures. All these aspects indicate how multifaceted and difficult a phenomenon this is to tackle. A combination of formal institutional attention with support from civil society and its "preventive" awareness may diminish the negative pattern building and create more visibility on the potential gaps.

\section{Findings}

Despite extant laws and regulations, there is still a fraction of businesses that have paperless and illegal workers or have abused foreign workers or commit other foreign worker-related financial crimes. Instead of casting shadows on legitimate businesses, effective governance practices and employment guidelines are needed. However, due to the limited number of officials and their investigative resources, 
their total number in Finland is unknown. Only the reported and solved crimes are in official statistics, although not all the reported crimes result in any convictions.

Recent findings trigger concerns on the application of regulation and laws for all. The key concern lies on the governance system that has not closed illicit windows of opportunity. In 2018, there were twelve cases involving a sort of modern-day slavery work in the hotel and restaurant industry in Finland, and eleven cases in other industries, where the employer had told the officials that the worker did not work in that location, but the parameters of the employment were fulfilled. In 2018, the challenges relating the foreign workers are still the hours that the workers actually work compared to the payment of work done (Vero 2018a). In 2018, tax officials found 1100 illegal workers, but the officials agree that they cannot identify all the illegal workers (Vero 2018b). In the era of transformation of work, where work becomes more fragmented and virtual, also more entrepreneurial and flexible, there will be an increasing demand for governance to catch up and address loopholes for exploitation (e.g., Rubery 2015).

We found dual-multiple layers in economic structures-with and without governance-like in Callebert's work (2014). Furthermore, according to the Central Organization of Finnish Trade Unions (SAK), there already existed a risk of a two-layer system in the capital city area in 2014, because of the difficulty of controlling immigrant employment, and the employers have, e.g., required their immigrant employees to sign unusual work contracts with requirements for "loyalty to the employer", not usually used in Finland, that can require excessive working hours (Pajunen 2014). One of these reported restaurant employers is a trendy restaurant Vapiano, which had not paid the Estonian workers according to the Finnish work laws (Pajunen 2014).

We identified key governance actors and the landscape of potential protection against abuse. As a result, we draw an illustration of the actors. Figure 2 presents a summary of organizations in Finland that deal with migrant workers: the police, the border control, and the customs are usually the first contact point when dealing with asylum seekers and immigrants. Then later on, when they have entered the country, trade unions or local employment offices are the next points of contact and they can check if the work conditions and salaries are paid according to the Finnish laws and regulations. If any of these previously mentioned officials find out that there is a victim or suspected victim of human trafficking, they can start the investigation process and different non-profit organizations can then step in and help the victims. 


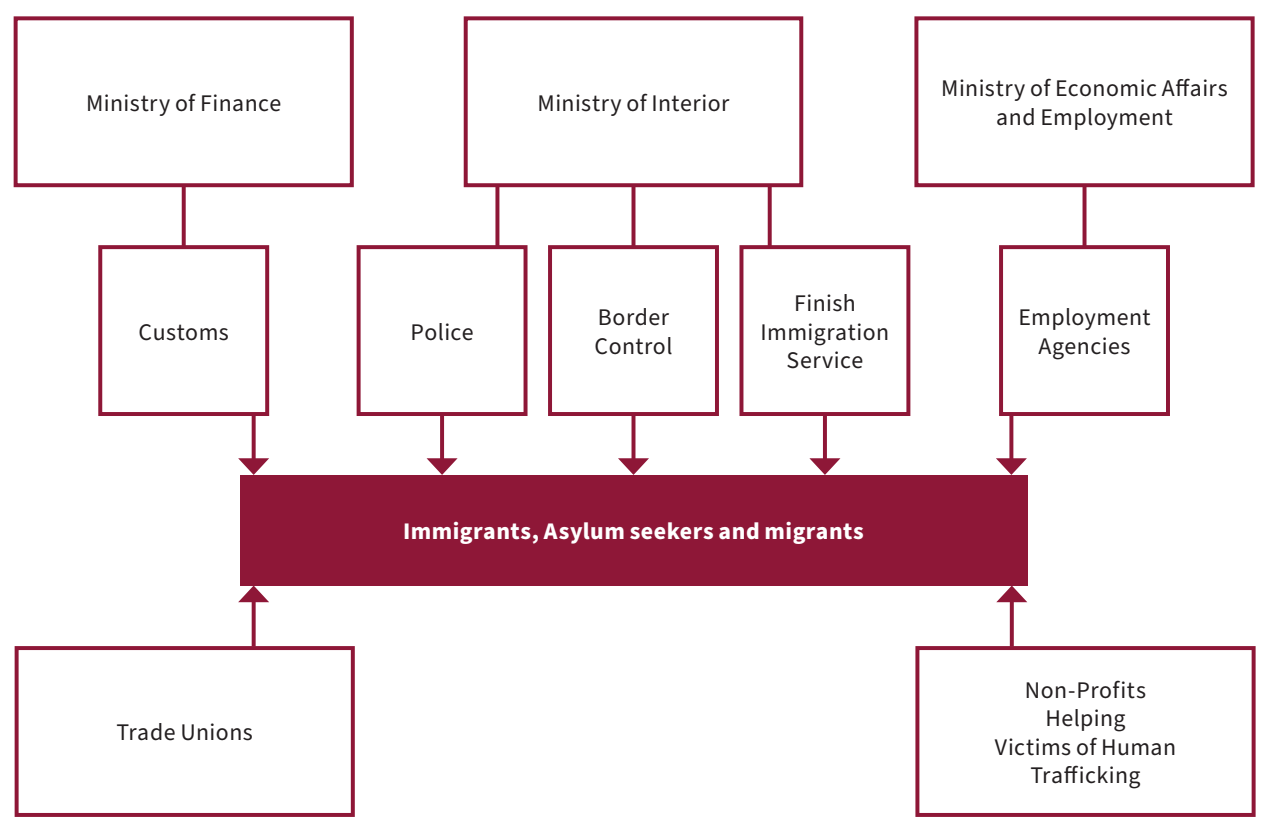

Figure 2. The Finnish organizations in contact with foreign workers and asylum seekers. Source: Authors.

\section{Discussion}

The methods that the government officials use to tackle the work violations among migrant workers and human trafficking are discussed next. First of all, there is cross-organizational training to recognize human trafficking and its victims, and to offer help via support organizations for the victims. Secondly, the unions work with the employers and officials tackle these problems. They investigate and report work violations and other crimes to the officials. However, the host societies have limited resources in unions and also within the police and tax administration to proceed more effectively. In addition, it takes time from the initial findings to prosecution and sentencing. It can take several years, and during this time, the employer can be involved in other crimes.

The unions and the officials offer online training and reports to educate the public as well as migrant workers and employers. The police also had a "grey economy" marketing campaign to fight financial crimes in businesses. These also made the civil society and consumers more aware of the abusive practices and financial crimes that can happen, especially in small businesses under the radar. We argue that the processes around illicit practices have their own distinct dynamics. 
Hence, conceptual clarity on such practices is a starting point. We reviewed the current features on two main types (see Figure 3 that presents the differences and similarities of human trafficking and abuse at work).

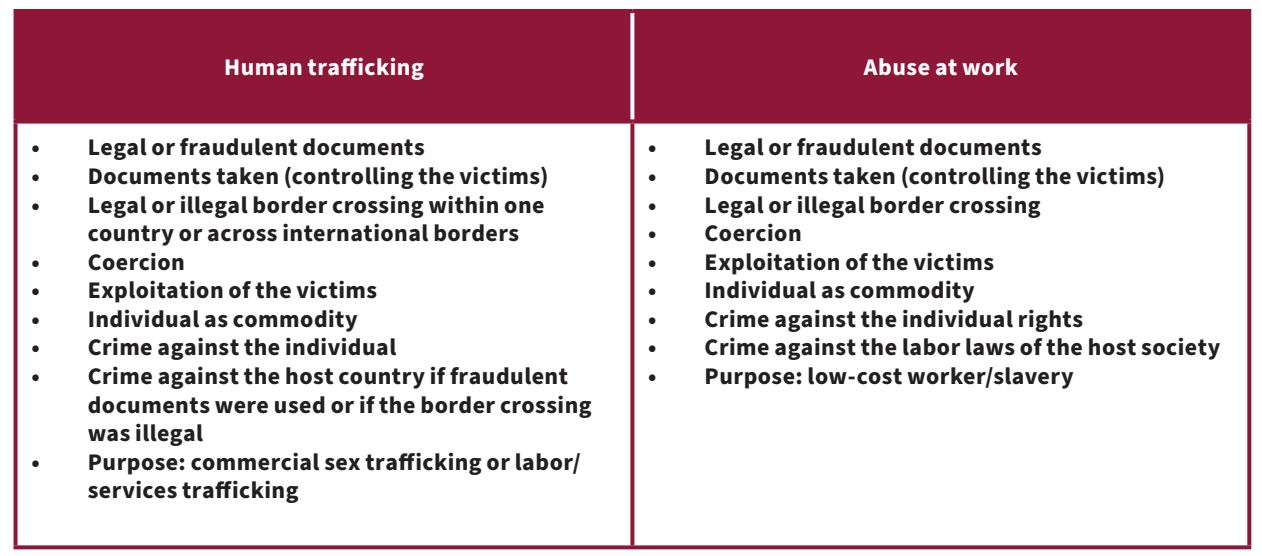

Figure 3. Summary of the differences and similarities in human trafficking and abuse at work. Source: Authors.

\section{Conclusions}

Theoretically, we suggest that there are distinct situations (e.g., pathways) and cases of illicit practices related to abuse, human trafficking, and slavery that need to be addressed carefully and specifically. The study underlines that this illicit and abusive behavior in business is by no means some historical phenomenon or triviality; it is also not something that is confined to poor developing countries. On the contrary, we claim that institutional "ignorance" in developed countries may serve such behavior by not closing loopholes or taking governance needs seriously, and thus letting abusive profit-making happen under illegal conditions.

For policymakers, the growth and maintenance of such abusive practices with financial implications reduces tax income, increases the divides, and creates social problems and negative traditions, undermining the legitimacy of the state. A cost-benefit analysis of regulating abuse could be an approach for the government officials to start with, as this has worked well in several advanced economies. Competitiveness of a country is linked to well-functioning institutions and a healthy economy that supports positive innovation and internationalization (Tung 2008; Kumar et al. 2013). Hence, the calls for less government to generate higher competitiveness and entrepreneurial energy can be seen as rather welcoming for 
abusive practices too, given that "gray economies" and illicit practices mushroom and grow faster as they do not pay the contributions that others pay.

Entrepreneurially, it is highly significant to avoid wrongdoing in the sense of negative brand image that could transfer to small- and medium-sized enterprises and family and ethnic businesses that are acting legitimately, trying to remain competitive following the laws and regulations. Managers and owners of these companies need support measures to differentiate between appropriate and illicit in the eyes of their customers and markets. Participation in UN SDG 8 campaigns and other identifications with legitimacy is suggested. Policies and programs educating foreign-born entrepreneurs on how to apply local laws and regulations can be improved to reduce possibilities of misunderstanding and institutional illiteracy. Simplified processual "driving licenses" for Finnish employment's rules of the game targeting employers and employees could foster a learning process, especially when available in English and other needed languages.

This paper is limited to a discussion on one country only, with a rather limited percentage of foreign-born people. It is also debating data from the legal system and statistics. Future research avenues could explore the establishment and profit-making mechanisms of abuse for a more detailed understanding of these practices. Longitudinal processual studies are needed that cover viewpoints from diverse stakeholders as efficient governance of work practices is difficult without the involvement of stakeholders. The emergence of non-governmental organizations and other civil society actors also deserves research attention, replacing some of the state's tasks in many contexts.

Author Contributions: Both authors contributed equally to the research and writing. All authors have read and agreed to the published version of the manuscript.

Funding: This research received no external funding.

Conflicts of Interest: The authors declare no conflict of interest.

\section{References}

Altinay, Levent, and Eser Altinay. 2006. Determinants of Ethnic Minority Entrepreneurial Growth in the Catering Sector. The Service Industries Journal 26, pp. 203-21. [CrossRef]

Barnard, Helena, David Deeds, Ram Mudambi, and Paul M. Vaaler. 2019. Migrants, migration policies, and international business research: Current trends and new directions. Journal of International Business Policy 2, pp. 275-88. [CrossRef]

Bell, Brian, and Stephen Machin. 2013. Immigrant enclaves and crime. Journal of Regional Science 53: 118-41. [CrossRef] 
Callebert, Ralph. 2014. Transcending Dual Economies: Reflections on 'Popular Economies in South Africa'. Africa 84, pp. 119-34. [CrossRef]

Chen, Yifeng, and Ulla Liukkunen. 2019. Enclave Governance and Transnational Labour Law-A Case Study of Chinese Workers on Strike in Africa. Nordic Journal of International Law 88, pp. 558-86. [CrossRef]

Chin, Christine B. 2003. Visible bodies, invisible work: State practices toward migrant women domestic workers in Malaysia. Asian and Pacific Migration Journal 12, pp. 49-73. [CrossRef]

Craig, Gary, Louise Waite, Hannah Lewis, and Klara Skrivankova, eds. 2015. Vulnerability, Exploitation and Migrants: Insecure Work in a Globalised Economy. Cham: Springer.

Daley, Clare. 2007. Exploring community connections: Community cohesion and refugee integration at a local level. Community Development Journal 44, pp. 158-71. [CrossRef]

Dana, Leo Paul, ed. 2007. Handbook of Research on Ethnic Minority Entrepreneurship: A Co-Evolutionary view on Resource Management. Cheltenham: Edward Elgar Publishing.

Davitti, Daria. 2010. Shrinking Responsibilities: Receiving Countries and the Structural Causes of Conflict-Related Child Trafficking. In Human Trafficking in Europe-Character, Causes and Consequences. Edited by Gillian Wylie and Penelope McRedmond. London: Palgrave McMillan, p. 42.

Délano Alonso, A., and Harris Mylonas. 2019. The microfoundations of diaspora politics: Unpacking the state and disaggregating the diaspora. Journal of Ethnic and Migration Studies 45, pp. 473-91. [CrossRef]

Denk, Nikola, Lutz Kaufmann, and Jan-Frederik Roesch. 2012. Liabilities of foreignness revisited: A review of contemporary studies and recommendations for future research. Journal of International Management 18, pp. 322-34. [CrossRef]

Dugan, Mahni, and Arnon Edelstein, eds. 2013. Migration Matters. Oxford: Interdisciplinary Press. Elo, Maria. 2017. Contemporary Labour Diaspora: The Finnish Challenges for Migration and Human Resource Flows. Immigrants and the Labour Markets, Experiences from Abroad and Finland. Turku: Migration Institute of Finland.

Elo, Maria, and Arla Juntunen. 2015. Securitization and diaspora networks-their evolving socio-economic role and impact. In Participation, Integration, and Recognition: Changing Pathways to Immigrant Incorporation. Turku: Migration Institute of Finland.

Finlex. 1959. Asetus Asetus orjuuden, orjakaupan ja orjuuteen verrattavien järjestelmien ja käytännön tukahduttamista koskevan lisäsopimuksen voimaansaattamisesta. Helsinki. April 10. Available online: https://www.finlex.fi/fi/sopimukset/sopsteksti/1959/19590017 (accessed on 29 September 2019).

Finnish Border Guard. 2014. In-Depth Interview. Turku: Finnish Border Guard, August 12.

Ghai, Dharam. 2008. Decent work: Concept and indicators. International Labour Review 142: 113-45. [CrossRef] 
Grzymała-Kazłowska, Alexandra. 2005. From ethnic cooperation to in-group competition: Undocumented Polish workers in Brussels. Journal of Ethnic and Migration Studies 31, pp. 675-97. [CrossRef]

Hamalainen, Veli-Pekka. 2018. Etnisen ravintolan pitäjä sai ehdollista vankeutta ihmiskaupasta Kuopiossa: Uhrit olivat lähes aina töissä, mutta palkat olivat olemattomia. Yle News. December 18. Available online: /yle.fi/uutiset/3-10554510 (accessed on 24 July 2019).

Hannus, Tanja. 2018. Ihmiskaupan Uhreja Tunnistetaan Suomessa yhä HeikostiHuumeidenkäyttäjä voi olla Ihmiskaupan uhri, jos hänet Pakotetaan Tekemään Rikoksia. November 16. Available online: yle.fi/uutiset/3-10509678 (accessed on 24 July 2019).

Haynes, Dina Franscesca. 2009. Exploitation nation: The thin and grey legal lines between trafficked persons and abused migrant laborers. Notre Dame Journal of Law, Ethics Public Policy 23, p. 1.

Heikkilä, Elli, ed. 2017. Immigrants and the Labour Markets. Experiences from Abroad and Finland. Turku: Migration Institute of Finland.

Heikkilä, Elli, and Maria Pikkarainen. 2010. Differential population development in the regions of Finland. Population, Space and Place 16, pp. 323-34. [CrossRef]

Heikkilä, Elli, and Daniel Rauhut, eds. 2015. Marriage Migration and Multicultural Relationships. Turku: Institute of Migration.

Heima, Timo-Pekka. 2019. Useissa nepalilaisissa ravintoloissa poljetaan räikeästi työntekijöiden oikeuksia. Yle News. March 30. Available online: yle.fi/uutiset/3-10714829 (accessed on 24 July 2019).

Heinonen, Jenni. 2010. Maahanmuuttajayrittäjät ja vastuullinen yritystoiminta, Kokemuksia, käsityksiä ja käytäntöjä. Web Reports 65. Turku: Siirtolaisuusinstituutti.

Hepple, Bob. 2005. Labour Laws and Global Trade. London: Bloomsbury Publishing.

Hughes, Donna M. 2000. The "Natasha" trade: The transnational shadow market of trafficking in women. Journal of International Affairs 53, pp. 625-51.

International Labor Organization (ILO). 2019. National Labour Law Profile: Republic of Finland. Available online: www.ilo.org/ifpdial/information-resources/national-labourlaw-profiles/WCMS_158896/lang--en/index.htm (accessed on 24 July 2019).

International Organization for Migration (IOM). 2019. International Migration Law, Glossary on Migration. IOM 1-248. Geneva: IOM.

Johanson, Jan, and Jan-Erik Vahlne. 2009. The Uppsala internationalization process model revisited: From liability of foreignness to liability of outsidership. Journal of International Business Studies 40, pp. 1411-31. [CrossRef]

Jureidini, Ray. 2010. Trafficking and contract migrant workers in the Middle East. International Migration 48, pp. 142-63. [CrossRef]

Karjalainen, Mari. 2014. Yle: Thai-Marjanpoimijat eivät Olleet Työsuhteessa Ber-Exiin. Available online: http://www.kainuunsanomat.fi/kainuun-sanomat/kotimaa/yle-thaimarjanpoimijat-eivat-olleet-tyosuhteessa-ber-exiin (accessed on 24 July 2019). 
Kelly, Robert J., Maghan Jess, and Joseph Serio. 2005. Illicit Trafficking: A Reference Handbook. Santa Barbara: ABC-CLIO.

Kolodziej, Edward A. 1992. Renaissance in security studies? Caveat lector! International Studies Quarterly 36, pp. 421-38. [CrossRef]

Kumar, Vikas, Ram Mudambi, and Sid Gray. 2013. Internationalization, innovation and institutions: The 3 I's underpinning the competitiveness of emerging market firms. Journal of International Management 19, pp. 203-6. [CrossRef]

Kupferberg, Feiwel. 2003. The established and the newcomers: What makes immigrant and women entrepreneurs so special? International Review of Sociology/Revue Internationale de Sociologie 13, pp. 89-104. [CrossRef]

Laitinen, Kari, Jukarainen Pirjo, and Boberg Henrik. 2016. Maahanmuutto \& TurvallisuusArvioita Nykytilasta ja Ennusteita Tulevaisuudelle, Valtioneuvoston Selvitys-Ja Tutkimustoiminta; Publications of the Government's Analysis, Assessment and Research Activities. Available online: https://julkaisut.valtioneuvosto.fi/handle/10024/79559 (accessed on 1 January 2020).

Lan, Tu. 2015. Industrial district and the multiplication of labour: The Chinese apparel industry in Prato, Italy. Antipode 47, pp. 158-78. [CrossRef]

Li, Yao-Tai. 2017. Constituting co-ethnic exploitation: The economic and cultural meanings of cash-in-hand jobs for ethnic Chinese migrants in Australia. Critical Sociology 43, pp. 919-32. [CrossRef]

Light, Ivan, Georges Sabagh, Mehri Bozorgmehr, and Claudia Der-Martirosian. 1994. Beyond the ethnic enclave economy. Social Problems 41, pp. 65-80. [CrossRef]

Martin, Nina. 2012. “There Is Abuse Everywhere" Migrant Nonprofit Organizations and the Problem of Precarious Work. Urban Affairs Review 48, pp. 389-416. [CrossRef]

Ministry of the Interior. 2016. Asylum Seekers in 2015. Immigration Department. Available online: web.archive.org/web/20160207142352/http://www.migri.fi:80/download/64990_ Tp-hakijat_2015.pdf (accessed on 24 July 2019).

Ministry of the Interior. 2018. International Migration 2017-2018-Report for Finland. Migration, Ministry of the Interior Publications 25. Helsinki: Immigration Department, ISBN 978-952-324-236-4. Available online: Julkaisut.valtioneuvosto.fi/bitstream/handle/ 10024/161174/25_2018_International_Migration_2017-2018.pdf?sequence=4 (accessed on 24 July 2019).

North, Douglass. 1990. A transaction cost theory of politics. Journal of Theoretical Politics 2, pp. 355-67. [CrossRef]

Ojo, Sanya, Sonny Nwankwo, and Ayantunji Gbadamosi. 2013. Ethnic entrepreneurship: The myths of informal and illegal enterprises in the UK. Entrepreneurship \& Regional Development 25, pp. 587-611.

Pajunen, Pirjo. 2014. Nykypäivän orjat. Available online: www.sak.fi/ajankohtaista/uutiset/ nykypaivan-orjat (accessed on 24 July 2019). 
Peterson, Abby, and Sara Uhnoo. 2012. Trials of loyalty: Ethnic minority police officers as 'outsiders' within a greedy institution. European Journal of Criminology 9, pp. 354-69. [CrossRef]

Porter, Michael E., and Mark R. Kramer. 2019. Creating shared value. In Managing Sustainable Business. Dordrecht: Springer, pp. 323-46.

Potrafke, Niklas. 2016. Policies against human trafficking: The role of religion and political institutions. Economics of Governance 17, pp. 353-86. [CrossRef]

Rath, Jan. 2000. Introduction: Immigrant businesses and their economic, politico-institutional and social environment. In Immigrant Businesses. London: Palgrave Macmillan, pp. 1-19.

Richards, Rebecca T., and Olli Saastamoinen. 2010. NTFP policy, access to markets and labour issues in Finland: Impacts of regionalization and globalization on the wild berry industry. In Wild Product Governance-Finding Policies That Work for Non-Timber Forest Products. Earthscan, People and Plants International Conservation Series; London: Earthscan, pp. 287-309.

Ristikari, Tiina. 2011. Maahanmuutosta ja työmarkkinoista, virkistäviä tulkintoja vieraidenkin perspektivistä. Työelämän tutkimus 9, pp. 192-93.

Rivera-Batiz, Francisco L. 1999. Undocumented workers in the labor market: An analysis of the earnings of legal and illegal Mexican immigrants in the United States. Journal of Population Economics 12: 91-116. [CrossRef]

Rönty, Heikki. 2014. Työneuvosto: Kapinoivat Thaipoimijat eivät olleet Työsuhteessa. Available online: http://yle.fi/uutiset/3-7342684 (accessed on 24 July 2019).

Rubery, Jill. 2015. Change at work: Feminisation, flexibilisation, fragmentation and financialisation. Employee Relations 37, pp. 633-44. [CrossRef]

Sanders, Jimy M., and Victor Nee. 1987. Limits of ethnic solidarity in the enclave economy. American Sociological Review 52, pp. 745-73. [CrossRef]

Santtu, Natri. 2019. Parittaja voi järjestää seksityöläisen Suomeen käymättä täällä itseAsiantuntijat Ylelle: Lainsäädäntö vaikeuttaa hyväksikäytön valvontaa. Yle News. July 13. Available online: Yle.fi/uutiset/3-10875415 (accessed on 24 July 2019).

Shelley, Louise. 2010. Human Trafficking: A Global Perspective. Cambridge: Cambridge University Press.

Shihadeh, Edward S., and Raymond E. Barranco. 2010. Leveraging the power of the ethnic enclave: Residential instability and violence in Latino communities. Sociological Spectrum 30, pp. 249-69. [CrossRef]

Statistics Finland. 2019. Population Statistics. Available online: https://www.stat.fi/til/vrm_en. html (accessed on 23 September 2019). 
STT, Markus Mäki, Johanna Malinen, and Matti Konttinen. 2019. Kolme suomalaista pääepäiltynä laajassa paritus-Ja rahanpesukokonaisuudessa-HS: Suomalaisten epäillään ylläpitäneen Sihteeriopisto-seksinmyyntisivustoa, poliisi ei vahvista. Yle News. July 10. Available online: Yle.fi/uutiset/3-10871296 (accessed on 24 July 2019).

Teittinen, Paavo. 2020. Loukussa, Helsingin Sanomat. March 8. Available online: https: //www.hs.fi/talous/art-2000006431472.html (accessed on 4 April 2020).

Transparency International. 2018. Corruption Perception Index 2018. Available online: https://www.transparency.org/cpi2018 (accessed on 4 April 2020).

Triandis, Harry C., Robert Bontempo, Marcelo J. Villareal, Masaaki Asai, and Nydia Lucca. 1988. Individualism and collectivism: Cross-cultural perspectives on self-ingroup relationships. Journal of personality and Social Psychology 54, p. 323. [CrossRef]

Tung, Rosalie L. 2008. Brain circulation, diaspora, and international competitiveness. European Management Journal 26, pp. 298-304. [CrossRef]

Turtola, Ilona. 2018. Suomessa voi olla satoja ihmiskaupan uhreja-“Jos puhumme nykyajan orjuudesta, se vääristää käsitystä mistä puhumme". Yle Nezws. August 14. Available online: yle.fi/uutiset/3-10351278 (accessed on 24 July 2019).

Ucnikova, Martina. 2014. OECD and Modern Slavery: How much aid money is spent to tackle the issue? Anti-Trafficking Review 3, pp. 133-50. Available online: www. antitraffickingreview.org (accessed on 24 July 2019). [CrossRef]

Vaarakallio, Sampo. 2013. Asiantuntija: Suomessa on yli 600 orjaa. Yle uutiset. October 5. Available online: https://yle.fi/uutiset/3-6866794 (accessed on 29 September 2019).

Vero. 2018a. Aluehallintovirasto Valvoo Ulkomaalaisten Työntekoa Suomessa. Harmaa Talous ja Talousrikollisuus. Finnish Tax Administration. 15 April 2019. Available online: www.vero.fi/harmaa-talous-rikollisuus/torjunta/ty\%C3\%B6nantajat-jatilaajavastuu/\#Elaketurvakeskus (accessed on 28 October 2019).

Vero. 2018b. Panostaminen Harmaan Talouden Torjuntaan on Kannattanut_Jatko Tulevan Hallituksen Vastuulla. Finnish Tax Administration. 16 April 2019. Available online: www.vero.fi/tietoa-verohallinnosta/uutishuone/lehdist \%c3\%b6tiedotteet/ 2019/panostaminen-harmaan-talouden-torjuntaan-on-kannattanut--jatko-tulevanhallituksen-vastuulla (accessed on 28 October 2019).

Vore, Adrian. 2015. 'Immigrant' vs. 'migrant'; What's the Difference? The San Diego Union-Tribune. September 25. Available online: www.sandiegouniontribune. com/opinion/readers-rep/sdut-immigrant-migranr-undocumented-europe-syria2015sep25-story.html (accessed on 28 October 2019).

Wahlbeck, Östen. 2007. Work in the kebab economy: A study of the ethnic economy of Turkish immigrants in Finland. Ethnicities 7, pp. 543-63. [CrossRef]

Waldinger, Roger D., Howard Aldrich, and Robin Ward, eds. 1990. Ethnic Entrepreneurs. Sozende Oaks: Sage. 
Walk Free Foundation. 2018. Global Slavery Index. Available online: www.globalslaveryindex. org/ (accessed on 24 July 2019).

Wilson, Tamar D. 1998. Weak ties, strong ties: Network principles in Mexican migration. Human Organization, pp. 394-403. [CrossRef]

(C) 2021 by the authors. Licensee MDPI, Basel, Switzerland. This article is an open access article distributed under the terms and conditions of the Creative Commons Attribution (CC BY) license (http://creativecommons.org/licenses/by/4.0/). 


\section{DeGeNT WORK AND \\ $\pi$}

\section{"Business as Part of the Solution": SDG 8 Challenges Popular Views in the Global Sustainability Discourse}

\section{Philipp Aerni}

\section{Introduction}

The UN Sustainable Development Goals (SDGs) were adopted by all UN Member States in 2015 with a time horizon of fifteen years to achieve them. The 17 Goals and 169 targets, which form the core of Agenda 2030, aim to effectively address the social, economic and environmental challenges of the 21st century by embarking on a global partnership designed to tackle the environmental, social and economic dimensions of sustainability simultaneously. Unlike prior global initiatives to save the environment (Rio Convention) or to eliminate poverty (Millennium Development Goals), the SDGs are the product of a joint effort that included high- and low-income countries as well as stakeholders from civil society, academia, government and business. The outcome is therefore based on a more inclusive process and, with it, enjoys more global legitimacy (Sachs 2015).

However, criticism about the alleged inconsistencies and contradictions of the goals, and its targets and indicators abound. There are indeed several overlaps and trade-offs between the different goals and their respective targets (Barbier and Burgess 2019).

Moreover, the indicators designed to measure progress on the different targets are perceived by some stakeholders to be rather crude or even misleading (MacFeely 2019). Moreover, the lack of data availability and lack of means to implement the ambitious goals, especially in low-income countries, will be a major challenge to measure and promote real progress (Barbier and Burgess 2019).

Yet, the SDGs represent a very useful global framework of orientation, and, more important, they stand for a paradigm shift in the sense that the private sector should cease to be merely seen as part of the problem, but envisioned as part of the solution (Scheyvens et al. 2016).

The UN Sustainable Development Goal 8 (SDG 8) on inclusive growth and decent work is at the heart of this paradigm shift. It is built on the insight that improving the material well-being of the most vulnerable people will require more investment in entrepreneurship and innovation on the local as well as the global level 
to enable inclusive and sustainable economic change. For that purpose, governments need to design facilitating policies that encourage businesses to invest in scalable innovations that address urgent sustainability challenges and generate inclusive prosperity (Juma 2016). This sort of people-centered prosperity requires a global partnership and a bigger appreciation of responsible and innovation-driven firms that understand that they do not operate in a vacuum but are part of society (Aerni 2018). ${ }^{1}$

Neither the Rio Principles on Environment and Development, nor the UN Millennium Development Goals (MDGs) have put such a great emphasis on the promotion of inclusive prosperity. In this context, SDG 8 is clearly a goal prioritized by the majority of the world, the countries where population growth, poverty, youth unand underemployment and internal migration are still the main challenges in efforts to embark on a transition toward sustainability. It is in these low- and middle-income countries where most of the world's population still lives in precarious conditions and where most workers lack any kind of formal employment contract, which would protect them from substandard working conditions that sometimes are equivalent to modern slavery (Aerni 2015a; Stoll 2019). Moreover, it is in these countries, where hundreds of millions of new jobs will have to be created by 2030, just to keep pace with the growth of the working age population.

Yet, SDG 8 has also been denounced by advocates and scholars of the so-called "degrowth" movement for being a sort of Trojan horse carrying "neoliberal" ideology in the global sustainability debate (Carant 2017; Rai et al. 2019). The idea of "degrowth" envisions an alternative economic system that is not built on the paradigm of economic growth. As such, its advocates may praise the targets of SDG 8 that deal with equal opportunity in employment (Target 8.5), the reduction of youth currently not in employment, education or training (Target 8.6), the abolishment modern slavery and child labor (8.6) and the protection of labor rights (Target 8.7). However, they take issue with the targets 8.1, 8.2 and 8.3 on promoting Gross Domestic Product (GDP) growth as well as entrepreneurship and innovation to create a more diversified and productive economy, especially in least developed countries (Frey 2017). They also question the idea of "Green Growth" as it is embodied in Target 8.4 with its aim to decouple economic growth from environmental degradation (Rai et al. 2019; Hickel and Kallis 2019; EEB 2019).

1 See also comment by Paloma Duran, Director of the UN SDG Fund: https://www.sdgfund.org/ businesses-heart-sustainable-development-goals (accessed on 13 October 2020). 
If one believes that it is affluence rather than poverty that has to be stopped in order to save the planet, then the opposition to targets 1, 2 and 3 of SDG 8 make sense. Economic development, as measured, among other indicators, by GDP growth rates, is incompatible with the vision and goals of the degrowth community for which GDP represents the harmful productivist logic that humankind must overcome (Rai et al. 2019). The growth-oriented targets of SDG 8 also run counter to the intention of the de-growth community to stop the alleged efforts to impose Western capitalist thinking on the rest of the world, to acknowledge and appreciate the value of unpaid work, especially done by women, and to debunk the view that innovation would be able prevent environmental collapse (Kallis et al. 2018).

This book chapter addresses these concerns but also highlights the elitist and paternalizing character of the degrowth mode of thinking. It reflects the viewpoint of a generation that has grown up affluent and is tired of it, which makes sense because affluence as such does not provide any meaning, orientation or identity (Eysenck 1990; Aerni and Bernauer 2006).

Yet, the UN SDGs were not launched to provide post-material societies with more psychological and spiritual well-being, as the degrowth community suggests (Kioupi and Voulvoulis 2019). Instead, they aim to address global challenges related to social exclusion, climate change and environmental degradation that have clear material consequences for the less affluent on this planet. These challenges must be addressed through effective public-private partnerships with the private sector as the main driver of economic change and job creation. This is also why the UN Secretary-General António Guterres called on all sectors of society to mobilize for a decade of action, ${ }^{2}$ and not activism, as many contemporary environmental organizations who also provide school material for education for sustainable development (ESD) seem to imply (Kioupi and Voulvoulis 2019).

SDG 8 is very much at the heart of this action-oriented agenda called Agenda 2030. It is based on the insight that business is essentially what people do to make a living and how they generate the means to care for their respective families and to address the challenges that emerge within their respective communities. For ordinary people, economic growth is not about ideology but opportunity. Once they benefit from business opportunities, they are more likely to meet their essential material needs and be able to care more about the future of the next generation (Aerni 2015a).

2 See UN Website on the Sustainable Development Agenda: https:/www.un.org/ sustainabledevelopment/development-agenda/ (accessed on 13 October 2020). 
Harnessing economic growth for inclusive and sustainable change, however, requires well-designed institutional framework conditions that encourage investments in scalable solutions that ensure an inclusive transition toward sustainability (Aerni 2018). How this works will be illustrated by means of concrete examples on how the global environmental challenges related to the ozone hole, acid rain and industrial agriculture have been addressed in an effective and inclusive way.

\section{The Importance of SDG 8 for UNCTAD}

The United Nations Conference on Trade and Development (UNCTAD) was established in 1964 in response to the demand from developing countries to address unfairness in the global trading system and to promote development.

Raul Prebisch, the first secretary general of UNCTAD, pointed at the problem with the terms of trade that largely favor high-income countries in international trade and drive low-income countries into debt. After all, the Global South primarily exports raw commodities, which face decreasing returns due to their low-income elasticity as inferior goods. As such, they are unable to cover for the costs of expensive capital goods imported from high-income countries to build up their domestic economies (Love 1980).

The current Secretary-General of UNCTAD, Mukhisa Kituyi, a Kenyan, believes that the solution to these structural challenges in international trade is not less trade-as advocated by many left-wing civil society institutions and right-wing populists in affluent countries-but better trade, fashioned by the principles of inclusivity and equity. ${ }^{3}$

How did it happen that UNCTAD, an institution mainly concerned with reducing global economic inequality and poverty, became a promoter of trade and foreign direct investment (FDI) in low-income countries? This is probably because the empirical evidence gathered over the past five decades clearly suggests that low-income countries can benefit from international business if they create adequate institutional framework conditions. These include smart domestic industrial policies that attract FDI while also enabling technological and knowledge transfer (Juma 2011; Juma and Yee-Cheong 2005). Evidence also shows that it is not market integration, but actually a lack of market integration that accounts for most of the extreme poverty in low-income countries (Hidalgo 2015; Bird 2019).

3 See blog written by Mukhisa Kituyi, Secretary-General of UNCTAD, on "Trade: a more nuanced approach" published on 23 March 2018: https://unctad.org/en/pages/newsdetails.aspx?OriginalVersionID=1699 (accessed on 13 October 2020). 
Since economic empowerment is a core concern of UNCTAD, it has an obvious interest in SDG 8 on inclusive growth and decent work (UNCTAD 2014a; UNCTAD 2014b). It also explains why UNCTAD believes that promoting entrepreneurship training (SDG 4.3 and $4.4^{4}$ ), protecting the rights of women entrepreneurs (SDG 5.5, A, B, C), investing in resilient infrastructure (SDG 9.1-5) to support growth-oriented domestic business and improving access to technology, capacity development (SDG 17.6-8) and trade (SDG 17.10-12) will greatly contribute to inclusive development in low-income countries while also enabling them to address their environmental challenges more effectively (UNCTAD 2018).

The importance of economic empowerment was already marginally present in the UN Millennium Development Goals (MDG 8 on promoting a global partnership for development) (Juma and Yee-Cheong 2005). Thanks to the more inclusive approach in the design of the UN SDGs, the issue has, however, gained importance. Despite the popular view among donors in high-income countries that economic growth is primarily a threat to sustainable development, they will have to respect the fact that recipient countries tend to see it more as an opportunity (Aerni et al. 2015). As signatories of the Organisation for Economic Cooperation and Development (OECD) Paris Declaration on Aid Effectiveness ${ }^{5}$ in 2005, donor countries pledged to respect the principle of ownership in development cooperation, which is all about taking local priorities in recipient countries more seriously. The principle was also reiterated by the OECD donor countries in the Busan Partnership for Effective Development Cooperation ${ }^{6}$ and is best described in the first of the four Busan partnership principles, which defines ownership of development priorities by developing counties as follows: "Countries should define the development model that they want to implement". So far, there are very few indications that development organizations who obtain their funding in high income countries would regard the supposed beneficiaries in low income countries as their clients and therefore respect their priorities (Aerni 2018; McCourt 2018). ${ }^{7}$

4 The Sustainable Development Goals consists of 17 Goals and 169 Targets. SDG 4.3. for example refers to Sustainable Development Goal 8, Target 4 . Sometimes there are also letters $(\mathrm{A}, \mathrm{B}, \mathrm{C})$ in addition to number that stand for particular targets to achieve a particular Goal.

5 See main principles of the OECD Paris Declaration: https://www.oecd.org/dac/effectiveness/ parisdeclarationandaccraagendaforaction.htm (accessed on 13 October 2020).

6 See website on the Busan Partnership: https://www.oecd.org/development/effectiveness/busanpartnership. htm (accessed on 13 October 2020).

7 See also the author's comment on the rhetoric of the German Minister of Development Cooperation: https://punkt4.info/social-news/news/demokratie-braucht-eine-wirtschaftlich-emanzipiertemittelklasse.html (accessed on 13 October 2020). 


\section{No Mention of a Paradigm Shift in the Global Sustainable Development Report (GSDR)}

The disregard of the ownership principle manifests itself also in the fact that leading academic and civil society institutions, mostly located in affluent OECD countries, are ignoring the demand for a paradigm shift in the SDGs.

The difficulties of integrating private-sector-driven entrepreneurship and innovation into a more comprehensive view of sustainable change is most visible in the recently published Global Sustainable Development Report (GSDR 2019) entitled "The Future is Now: Science for Achieving Sustainable Development". The GSDR was one of the outcomes of the Rio + 20 Conference in Rio de Janeiro, Brazil, on the "Future We Want". Its purpose was to create a high-level political forum on sustainable development (HLPF) that would also strengthen the science-policy interface, building on existing assessments on the state of sustainable development. After the UN SDGs were approved by the UN General Assembly on 25 September 2015 , member states eventually decided that the report should be produced by an independent group of scientists, appointed by the UN Secretary-General, once every four years, to inform the UN General Assembly on the state of the SDGs.

Even though GSDR does a good job of describing the current state of global sustainable development from a scientific perspective, it does not refer to any paradigm shift associated with the insight that business must become part of the solution. SDG 8 is only discussed in the context of targets related to labor rights standards and the problem of child labor. Its call to generate inclusive economic growth and to upgrade and diversify formal growth-oriented business is largely ignored. In this context, the report fails to connect sustainability science to the role of entrepreneurship and innovation as drivers of sustainable change, which explains why there is no reference to the UN resolution 69/210 on entrepreneurship for sustainable development. ${ }^{8}$ It also explains why the GSDR would not mention anywhere that in many regions of this world, poverty, combined with population growth, rather than affluence may still pose the greatest threat to the environment and social well-being (Aerni 2015b; Hollander 2003).

8 The UN Resolution 69/210 on Entrepreneurship for Development was adopted by the General Assembly of the United Nations on 19 December 2014: https://undocs.org/en/A/RES/69/210 (visited on 13 October 2020). It recognizes the important contribution that entrepreneurship makes to sustainable development by creating jobs and driving economic growth and innovation, improving social conditions and addressing environmental challenges. 
For most low-income countries, the expansion of the informal economy is not just a manifestation of alternative "livelihoods" (a term used in the GSDR about 50 times) as some scholars suggest (Ruzek 2015). According to the International Labor Organisation of the United Nations (ILO 2014), the informal economy is rather a poverty trap, if not an outright indicator for stunted development. For most young people who grow up in the informal sector, the likelihood that their improved access to education will translate into better economic opportunities is tiny. Instead they end up in most cases as self-employed daily laborers or in precarious informal employment. As such, they lack a formal employment contract that would legally protect their labor rights (Aerni 2018).

Moreover, they do not have any formally registered property that would enable them to attract investment; and they lack access to social security and access to other essential public goods (Aryeetey 2015). That is why SDG 8 addresses the protection of the rights of migrant workers, particularly women migrants and those in precarious employment (SDG 8.8). Improving the situation of these marginalized members of society is of crucial importance to inclusive sustainable change. The focus on the improvement of the economic situation of the vulnerable is also reflected in other targets of SDG 8, such as 8.9 on promoting sustainable tourism, 8.10 on financial inclusion and 8a on trade facilitation. They represent additional means to this end.

Despite taking stock of the global state of sustainable development, the GSDR report rarely addresses these existential concerns of people in the majority world that still struggle to meet their essential material needs because of lack of economic prospects. As a consequence, the report tends to disregard the human-centered approach of UN SDGs with its focus on the need of every human being to eventually become integrated in business and society (Arts 2017). Instead, the GSDR focuses on the description of sustainability challenges that are almost exclusively portrayed as negative by-products of economic and technological change. This is odd, because, after all, the SDGs are about People, Planet and Prosperity and not People, Planet minus Prosperity.

\section{Human Ingenuity Challenging the Malthusian Narrative of Environmental Collapse}

By framing material prosperity primarily as a threat to people and the planet, the GSDR is well-aligned with the account on planetary boundaries in "Sustainability Science" (Foley 2017; Folke et al. 2016). This account is based on the neo-Malthusian narrative of the environmental movement of the 1970s predicting the limits to growth 
and the looming environmental collapse caused by population growth and the human pursuit of material wealth (Meadows et al. 1972).

This narrative, however, has been challenged by the empirical work of pioneers in sustainability research in developing countries such as Ester Boserup (Boserup 1981), Alfred O. Hirschman (Hirschman 1992) and Jack Hollander (Hollander 2003), as well as interdisciplinary scholars such as Jane Jacobs $(1969,1984)$, who explore the sustainability potential of innovation ecosystems. Especially the ideas of Janes Jacobs have been recently validated in research on life-cycle solutions (McDonough and Braungart 2013; Rockström and Kulm 2015).

The baseline assumptions of Thomas Malthus were also challenged on theoretical grounds by Paul Romer (Romer 1990), the Winner of the Nobel Prize in Economics in 2018, and César Hidalgo (Hidalgo 2015), one of the leading scholars in the new field of economic complexity. They argue that population growth would indeed ruin the environment, if you ignore the impressive track record of humankind in responding to scarcity through technological and institutional change. ${ }^{9}$

In order to understand why population growth and increasing affluence have not led to environmental collapse so far, one needs to take into account the role of knowledge as the only non-scarce and, therefore, non-rival resource available to manage the scarce resources on this planet. According to Romer, knowledge creates social value only when entrepreneurial teams with the appropriate skills and know-how are able to convert it into new goods and services that address particular needs or problems in society (Romer 2010). As such, innovative entrepreneurial teams may create new markets with large and often unintended positive external effects for society and the environment (Aerni 2018; Naam 2013). In other words, they may enable humankind to embark on a journey of sustainable intensification that renders the concept of the so-called carrying capacity in ecology meaningless when applied to the human species (Haberl and Erb 2017). This is, in essence, also the argument of Ester Boserup (Boserup 1981), who pointed out that population growth does not just create more pressure on scarce natural resources, but also leads to a larger work force and more human brainpower to find innovative solutions to scarcity problems and help restore prior environmental damage.

9 Cesar Hidalgo refers in this context to the law of entropy that would predict all things alive move towards disorder and eventual disappearance. This also applies to the human being as an individual, but not to the species of humankind in general that makes use of information (knowledge and know-how) passed on over generations, to create order, in the sense of converting natural space into cultural space (Hidalgo 2015). 
This is not to deny that innovations, which result in new markets with increasing returns, do not generate negative externalities or cause re-bound effects that cancel out the efficiency gains in production through the stimulation of more consumption (EEB 2019). However, the net-impact of scalable innovation may nevertheless be positive, especially when the innovation results in an affordable substitute for an existing problematic product that causes large negative externalities (Naam 2013; Kaiser et al. 2012).

Often, however, there is reluctance in business to invest in such disruptive innovations that could potentially generate large positive external benefits for society, especially because these benefits cannot be captured by the investing company itself; they go to society at large. A second reason is organized resistance against innovation that may threaten the social acceptance of a disruptive new technology. Organized resistance is supported by incumbents in business that benefit from the status quo (Juma 2016). In view of the high degree of risk and uncertainty related to private sector investments in disruptive innovation, governments need to come up with a long-term plan designed to lower institutional uncertainty and, with it, increase the likelihood of business to generate a return on investment. In this context, it must be ensured that a long-term government strategy cannot easily be derailed with the next election (Mazzucato 2013).

\section{Understanding the Popularity of "Degrowth" from a Historical Perspective}

The community of scholar-activists who propose the normative concept of "degrowth" as a sustainable alternative to the current growth-oriented global capitalist system challenge the view that business can be part of the solution (Kallis et al. 2018; Kallis et al. 2012). They tend to portray advocacy for technological change as a reductionist approach (technological fix) that would not take into account "systemic" thinking and thus produce irreversible unintended negative side effects in ecosystems that may also have long-term economic consequences (Jackson 2009). The German sociologist Arnold Gehlen (1988) argues, however, that there is no alternative to trial and error in the history of humankind when facing existential scarcity problems. As unspecialized deficient animals, human beings have to innovate in order to survive in a particular ecosystem. These innovations may have negative unintended consequences, which, once again, have to be addressed by further converting natural space into cultural space through human intervention, but that is part of the never-ending learning process (Gehlen 1988).

By disregarding this essential insight from philosophical anthropology, the degrowth community may run the risk of embracing a reductionist approach. 
After all, it interprets this process of human development merely from an ideological perspective, namely as an interplay of the expansion of capitalism and its opponents who have historically preferred alternative economic systems (Kallis et al. 2018; Latouche 2007). In consequence, their criticism of the UN SDGs mainly focuses on the first three targets of SDG 8 because they suggest more rather than less innovation-induced economic growth in efforts to create a more sustainable and inclusive society (Carant 2017; Rai et al. 2019; Frey 2017; Gerold 2019).

The argument of degrowth advocates resonates well with a public discourse on sustainable development in postmaterialist societies that is shaped by bipolar baseline assumptions reflected in slogans such as "defending people's interest against profit", "punishing big business for offending basic human rights" or "ending climate change by ending capitalism" (Aerni 2018). ${ }^{10}$

The general view that global companies pose a major threat to human rights by doing business at the expense of local cultural and economic rights is firmly entrenched in the sustainability debate of affluent societies and remains largely unchallenged in academia (Sikkink 2019).

The current defensive and polarized global discourse on sustainability may also be understood as a response to the recent global crises. The financial crisis and the subsequent food crises that took place at the end of the first decade of the 21st century resulted in a general disillusion with the global economy and triggered a longing for alternative economic systems that would be more sustainable, fair and inclusive. In this context, the subsequent movements in civil society and academia ranging from Occupy Wall Street (Sikkink 2019) to Food Sovereignty (Hardt and Negri 2011) up to the latest Global Climate Strikes (Holt-Giménez and Altieri 2013) are comparable to the emergence of the powerful social movements of the 1970s (Aerni 2018; Wright and Nyberg 2019). Back then it was the oil crisis that triggered an economic crisis combined with a confidence crisis in industrialized countries (Bosse 2019), in addition to a food crisis in developing countries (Lipset and Schneider 1983). Advocacy groups protested against a Cold War elite mainly concerned with industrial progress and military rearmament, but tended to ignore its environmental and social consequences (Devereux 2000). There was already a lot of talk about the limits to growth (Meadows et al. 1972), the risks of modern technologies, as well as the lack of openness and transparency in business and government (Gottlieb 1993).

10 See article in the Guardian that illustrates the bipolar framing: https://www.theguardian.com/ commentisfree/2019/mar/18/ending-climate-change-end-capitalism (accessed on 13 October 2020). 
Moreover, there were discussions on alternative economic systems that would focus less on economic growth and more on equality and social well-being-a sort of third way between market economy and classical socialism (Šik 1976; Kalb 2002). In this context, the Gross Domestic Product (GDP) ${ }^{11}$ as an indicator of a country's level of human development was already a target of criticism. The arguments were very similar to the ones voiced again recently (Boarini et al. 2006): GDP ignores the distribution of income, does not take into account other quality-of-life factors, such as literacy, life expectancy or treatment of minorities, ignores the value of unpaid work and fails to factor in the environment costs associated with GDP growth.

The activists of the 1970s have successfully completed the march through the institutions of democracy and the market economy and transformed them accordingly. As a consequence, environmental issues and transparency in business and politics have gradually climbed in importance on government agendas (Masood 2016; Fiorini 1998). Moreover, the United Nations Human Development Program (UNDP) has responded to the criticism regarding GDP rankings by adopting a human development index in 1990, while Clifford Cobb and Hermann Daly launched the Genuine Progress Indicator (GPI) and Robert Putnam the Indicator of Social Health (ISH). They all depart from merely measuring a society's total income and its total expenditure on newly produced goods and services and focus instead on the improvement of non-material aspects. Similarly, some eco-minded economists have tried to add to the GDP an imputed dollar value of the benefits derived from a healthy environment (Zürn 1998).

Yet, academia and civil society advocates of degrowth ${ }^{12}$ do not believe that some amendments to the GDP will do because they find the general idea behind the indicator to be flawed: the so-called growth imperative implying that economic growth would be a panacea for all social and economic problems (Rai et al. 2019; Costanza et al. 1997). This imperative would ignore the planetary boundaries that humankind may eventually have to learn to cope with by stopping global economic expansion and instead returning to a more local and autonomous caring-type of economy (Jackson 2009; Raworth 2012).

11 According to the Bureau of Economic Analysis of the United States, the Gross domestic product (GDP) is the value of the goods and services produced by the nation's economy less the value of the goods and services used up in production. GDP is also equal to the sum of personal consumption expenditures, gross private domestic investment, net exports of goods and services, and government consumption expenditures and gross investment.

12 Degrowth is defined by ecological economists as an equitable downscaling of throughput, with a concomitant securing of wellbeing (Kallis et al. 2018). 
In this context, advocates of degrowth argue that there is a need to break the productivist logic in modern capitalist society in order to restore a "decolonized" vision of well-being as it is believed to have existed in all human cultures and knowledge traditions prior to capitalism (Kallis et al. 2018). Such a return to the roots would also stop unchecked environmental depletion as a result of an unfettered materialist consumption culture (Rai et al. 2019). The idea of degrowth is also present in many recent manifestos for alternative economic systems (Latouche 2007; Paech 2012; Rifkin 2014; Jackson 2019). Some call for reforms of the existing capitalist system, while others call for a revolution to topple it entirely. Most authors advocate a radical change in lifestyle, becoming virtuous out of necessity by embracing low-impact livelihoods that promote well-being and equality while stopping environmental degradation (Kallis et al. 2018; Latouche 2010).

Degrowth demands are also related to feminist concerns related to gendered forms of unpaid labor on which capitalism would rely, but not respect (Rai et al. 2019), as well as food sovereignty concerns. The food sovereignty movement has identified industrial agriculture as the main source of harm for biodiversity, food culture, decent employment, food security and environmental degradation (Aerni 2011). It advocates instead for a return to local food systems based on agro-ecological principles (Holt-Giménez and Altieri 2013; Vivero-Pol et al. 2018).

Degrowth activists are also convinced that a reduction in economic output can go hand in hand with more engagement in distributive justice and the promotion of social equality (Kallis et al. 2018). It would simply require a set of integrated policy reforms that compensate wage losses due to a reduction in working hours by increasing hourly wages with a living wage policy. Moreover, a universal basic income (UBI) could be introduced to mitigate the impact on small businesses that would struggle paying higher hourly wages combined with dividends funded by taxation on carbon, wealth, land value, resource extraction, and corporate profits (Hickel and Kallis 2019; Victor 2008).

\section{Déjà vu: The Affinity of the Youth Climate Movement to the Old Ideas of Degrowth}

In her dramatic speech to the UN General Assembly on 23 September 2019, climate change activist and founder of the Fridays for Future Movement, Greta Thunberg, very much endorsed the world view of the degrowth community when she argued that "People are suffering. People are dying. Entire ecosystems are collapsing. 
We are at the beginning of a mass extinction and all you can talk about is money and fairytales of eternal economic growth, how dare you!"13

Thunberg and her young fellow activists also take great care in ensuring that their lifestyles are in line with their rhetoric and their post-material values. They practice the art of low-impact livelihood in an affluent and materialist culture.

All this is admirable, and no one would question their idealism and the authenticity of their struggle for a livable future. Yet, there has been a very similar earlier environmental youth movement more than thirty years ago that also equated environmentalism with lifestyle and resistance against technological change and economic growth (Beck 1986; Braungart and Braungart 1990; Rifkin 1990). This movement emerged in high schools in affluent countries in the 1980s, once school textbooks and documentaries started to highlight the negative side effects of industrialization on the environment, society and human health. Particular concerns were the damages caused to forests by acid rain and the shrinking ozone layer in the atmosphere (Clark et al. 2001). As a result, pressure for political action increased and eventually led to the Brundtland Report outlining the principles of sustainable development in 1987, the Montreal Protocol on Substances that Deplete the Ozone Layer, in force since 1989, and the first UN Conference on Development and Environment (UNCED) in 1992 with its ambitious Agenda 21.

\section{Technological Change Framed as an Opportunity to Facilitate New Forms of Cooperation}

The fourth industrial revolution was a term coined by Klaus Schwab in an article in Foreign Affairs in 2015 (Schwab 2015). It refers to the convergence of different technologies in the fields of robotics, artificial intelligence, nanotechnology, quantum computing, biotechnology, 3D printing and the internet of things. Its impact on communication and connectivity in society and the global economy in the 21st century is likely to transform life as a whole on this planet. There are the doomsayers who predict that this will lead to the destruction of many traditional industries, the devaluation of practical skills, the end of privacy and lots of unemployment due to that fact that robots will execute almost any function that humans currently perform. Yet, this line of argumentation ignores one crucial fact: the human mind did not evolve by solving problems on its own

13 Transcribed talk by Greta Thunberg available online: https://unfoundation.org/blog/post/powerfulspeeches-un-general-assembly/ (accessed on 13 October 2020). 
but through "shared intentionality" enabling well-coordinated group collaboration (Fernbach and Sloman 2017; Hosoya and Schaefer 2020). In other words, individuals are meant to think and work in conjunction with the thinking and working of others. The group intelligence that emerges from shared intentionality of people in pursuit of a common purpose goes far beyond individual physical and intellectual skills and, therefore, also far beyond the capacity of a robot.

Advanced techniques of deep learning may enable robots to do any job faster and better than humans, but they will never be able to create new markets that result in new jobs. These markets are always the result of shared intentionality combining the different mental and physical skills of humans to achieve a particular outcome (Fernbach and Sloman 2017).

New communication technologies can be harnessed to improve the ability of humans to collaborate across space and time and to translate ideas into concrete and safe products and services that help address specific challenges. As such, these technologies are likely to become tools of economic empowerment and increase appreciation for cultural achievements elsewhere, provided that the institutional framework conditions and the physical and digital infrastructure are supportive of such endeavors and inclusive by nature (Juma 2016; Aerni 2018).

\section{Reimaging the Contribution of Urban Landscapes to Sustainable Change}

New urban spaces that open up for the creation of a new type of industrious city (Hosoya and Schaefer 2020) may serve as an enabling platform designed to re-empower local business-taking advantage of advanced technologies, specialized business services and standardized modules of production that have become user-friendly and affordable. Such an industrious city may emerge in a former industrial zone of a larger established city in a high-income country (Schaefer 2020) or as a greenfield project in the form of a new city designed to better connect rural areas in a low-income country with centers of prosperity (Aerni 2020). An emerging new city can be envisioned as a special industrial zone offering all the amenities and institutions to attract long-term investments, which then result in technology transfer, capacity development and more investment in the production of domestic goods and services, not just for the city with its global network but also for its rural hinterland. Industrious cities must, therefore, be seen in the context of extended urban landscapes integrating rural areas in a fruitful economic symbiosis. Such landscapes comprise various levels of governance that set up coordinating bodies designed to create institutional framework conditions that enable an industrious city and its surroundings to thrive, create valuable new jobs and lower the pressure of migration 
(Aerni 2016a). According to Jane Jacobs, such cities prosper and expand if they can achieve their purpose, which is reinventing urbanity as a location that enables productive exchange directed toward the constant creation of new markets adding new work to old work (Jacobs 1969). This purpose can only be achieved, however, by overcoming the bipolar mindset in which business is denounced as an external black box driving the introduction of new technologies and urban expansion at the expense of traditional practices and local culture (Aerni 2018)

\section{Public-Private Partnerships for Sustainable Change after the UNCED in Rio in 1992}

In retrospect, humankind may have failed to address certain challenges related to biodiversity loss or global climate change that were identified during the United Nations Conference on Environment and Development (UNCED) in Rio in 1992 (UNCTAD 2014a). However, there are also success stories that should be acknowledged.

\subsection{The Montreal Protocol on Substances that Deplete the Ozone Layer}

A good example of a success story is the Montreal Protocol on Substances that Deplete the Ozone Layer; thanks to its effective phase-out management plan in 1987 to get rid of Chlorofluorocarbons (CFCs), the cause of the existential threat of a growing ozone hole in the atmosphere, humankind was able to avert the looming catastrophe. The plan was implemented by a global public-private partnership providing crucial support to enable poor countries to adopt affordable substitute refrigerants called hydrofluorocarbons (HFCs) (Mäder et al. 2010). While HFCs are safe for the ozone, they are also a powerful greenhouse gas. The Kigali amendment to the Protocol, which entered into force on 1 January 2019, addresses this concern. It aims to replace the use of HFCs with refrigerants that are less harmful greenhouse gases.

\subsection{Acid Rain as a Result of Industrial Pollution}

Acid rain also ceased to be a major environmental concern thanks to effective action combining effective regulation and scalable innovation: sulfur dioxide (SO2) and nitrous oxide (NOx) emissions, which were widely held responsible for the phenomenon of acid rain, have been dramatically reduced in the last 25 years. This was possible thanks to sophisticated filter technologies, flue gas cleaning and catalytic converters in exhaust systems. Incentive-based regulation based on trade in polluting permits helped to make the adoption of these technologies also profitable for companies (Stavins 1995). 


\subsection{Environmental Agreements Are More Effective If They See Business as Part of the Solution}

What these two success stories have in common is the fact that business became part of the solution: through the capacity to innovate (e.g., CFC-free refrigeration and filter technologies) and subsequently convert the innovative prototypes into scalable business solutions, not just in developed but also in developing countries. In addition, business contributed through the willingness to join public-private initiatives to jointly tackle the challenges. Public sector leadership was important in coordinating regulatory and facilitating policies with the most important stakeholders in business and civil society to enable joint effective action (Naam 2013; Juma 1994; Aerni 2015b).

The two large UN conventions on climate change (Framework Convention on Climate Change, UN FCCC) and biodiversity (Convention on Biological Diversity, UN CBD) proved to be less effective. This may not just be related to the complexity of the challenges but also a different mindset that shaped the discourse in the annual Conference of the Parties (COP) of the conventions. They tended to implicitly frame the challenges as the negative externalities of technological and economic change that have to be regulated accordingly (Prins and Rayner 2007; Prathapan et al. 2018; Aerni 2019a).

During the design of these conventions, it was not taken into account that scalable technologies that may effectively help to substitute problematic products and processes were not yet available (Juma 2016). In view of the absence of long-term government initiatives to invest in future-oriented technological transformation, the private sector was also reluctant to respond effectively to more strict regulation through innovation (Goldstein et al. 2020).

Facilitating policies designed to enable change combined with coordinated action with business and civil society would have been a way for governments to address the challenge more effectively. However, neither the Kyoto Protocol on climate change (an extension of FCCC) nor the Cartagena Protocol on biosafety (an extension of CBD) foresee any concrete action plan on technology development and transfer, comparable to the joint action plan under the Montreal Protocol (Prins and Rayner 2007; Overmann and Scholz 2017).

In other words, the role of innovation and entrepreneurship as drivers of sustainable change in business and society was not taken into account, either in the FCCC or in the CBD; and, with it, the opportunities for business to develop a scalable market for environmental goods were largely ignored (Aerni 2015b). The stakeholders that dominated the agenda of the subsequent COPs of these conventions often put ideology before pragmatic action. For example, by opposing the use of advanced 
nuclear technology and biotechnology in general, a concrete case-by-case evaluation of different options related to these platform technologies was no longer possible. ${ }^{14}$ A balanced assessment of these technologies would have been more in line with the basic principles of risk management that are meant to guide the application of the Precautionary Principle (PP), which environmental activists otherwise very much endorse (Aerni 2019b; Stefánsson 2019). After all, the PP is less about preventing technological risk and more about coping effectively with global environmental threats such as climate change by making use of all available options. In this context, potential technological risks must be compared to potential technological benefits for society and the environment, taking into account the rapid evolution of the respective technology (Aerni 2019b; EC 2002).

\section{The Problem with Education for Sustainable Development}

According to the United Nations Educational, Scientific and Cultural Organization (UNESCO), Education for Sustainable Development (ESD) aims to "empower learners to make informed decisions and responsible actions for environmental integrity, economic viability and a just society, for present and future generations, while respecting cultural diversity". ${ }^{15}$ Even though no one questions the urgency to teach sustainable development, the concrete content of teaching is kept deliberately vague. It is about "promoting core competencies, such as critical and systemic thinking, collaborative decision-making, and taking responsibility for present and future generations". However, what this exactly means is left to teachers, who will be free to select educational material that reflects their personal normative views of sustainable development.

\subsection{Predominance of Schematic Views and Lack of Critical Evaluation}

Contemporary educational material on sustainability issues in high schools tends to rely heavily on visual sources taken from social media and research documentaries on business and the environment (Alyaz et al. 2016). This material is often normative in nature; it is associated with advocacy for community solidarity, spirituality and

14 See Interview with Calestous Juma on 23 May 2015 at the University of Zurich: https://www.news.uzh. ch/de/articles/2015/technologische-umbrueche-provozieren-immer-kritik.htm (accessed on 13 October 2020).

15 See https://en.unesco.org/themes/education-sustainable-development/what-is-esd (accessed on 13 October 2020). 
traditional knowledge that is believed to contribute to the "unfinished enlightenment project of reason" (Fadeeva and Mochizuki 2010).

Often the discourse on ESD in academic journals lacks any critical self-reflection by comparing stories told in class with actual empirical evidence gathered in the field (Winter 2007). As a consequence, educational material is based on schematic views that do not contain any critical evaluation of prior successes and failures on environmental challenges (Aerni and Oser 2011). Moreover, they tend to portray the use of the Precautionary Principle mainly as a tool to protect society from risks resulting from economic and technological change rather than a tool for responsible and balanced risk management (Winter 2007; Aerni 2013).

\subsection{Green Consumerism: Dividing the World into Good and Bad Choices}

Empirical research on sustainability textbook content reveals a tendency to frame the issues as a binary ethical choice (Kowasch and Lippe 2019), also associated with "green consumerism" (Moisander 2007). It implies that "you", as an individual and consumer, have the power to change the world through "your" choice (Rieckmann 2017). Pick the product with an ethical label that stands for your social values on human rights and the environment, and shun products from corporations that have been shamed for undermining these values. While choosing the more expensive product that carries an ethical label also reflects a psychological need for virtue signaling (Orlitzky and Monga 2018), avoiding products from boycotted companies is linked to the phenomenon of ecological scapegoating (Schmitt 2019). As such, green consumerism helps to reduce complexity and provides meaning, identity and a normative orientation. This affective brand identification also makes it easier to re-tell the stories to others (Casidy et al. 2019). Yet, such consumer choices may reveal more about the need to signal one's prosocial status to others than genuine effort to address global sustainability challenges through concrete collective action (Miller 2001; Luomala et al. 2020). Because green consumerism is so easy to communicate and causes individual well-being, companies often make use of its schematic views in green marketing strategies to insinuate to consumers and customers that they would share their sustainability-related values (Aerni 2013; Autio et al. 2009). Textbooks embrace such views for the same reason: it is easy to tell a good story. ${ }^{16}$

16 "Globi", a popular Swiss picture book series suited for children in elementary school builds on such easy to tell schematic views. Globi is a jolly parrot who always draws some moral lessons from an experienced adventure. In the Globi edition "the smart farmer", Globi is told by a female African subsistence farmer that organic agriculture is more sustainable than conventional agriculture. This is 


\subsection{Become an Activist! Role Models Communicated in ESD}

The use of visual media in schools, such as documentaries, tend to follow a "win-win" logic, similar to the one of green consumerism. It is designed to generate a good return on investment by responding effectively to the viewers' need for meaning and orientation (Hirsch and Nisbet 2007). Often, the collection of facts is guided by an approach called selectivity bias (Slater 2007) or application hermeneutics (Langewand 1999). It carefully selects the facts to ensure that the story being told and its core message are clear and unambiguous, and embedded in a convincing narrative with emotional flow (Nabi et al. 2018; Nabi and Green 2015). Incidences that would contradict the core message tend to be omitted or voiced by someone who cannot be trusted. Often the dramatization and personalization reduce research documentaries to a theater play containing actors with good motives, e.g., environmentalists defending "nature" with its endangered species, indigenous groups, and actors with bad motives, e.g., business executives that would like to make profits at the expense of people and the environment (Aerni 2018). In most cases, agency is assigned to NGOs that claim to act in the public interest as well as to the business-oriented perpetrators, while local people and their environment merely provide the "natural" setting in which the action takes place (Rangan 2000).

Most award-winning environmental documentaries or stories about environmentalists, such as "Erin Brokovich: A True Story" by Steven Soderberg in 2000, "Darwin's Nightmare" by Hubert Sauper in 2004, "We feed the World" by Erwin Wagenhofer in 2005, "The World According to Monsanto" by Marie-Monique Robin in 2009, "This Changes Everything" by Avi Lewis and Naomi Klein in 2015, or "Bruno Manser: The Voice of the Rainforest" by Niklaus Hilber in 2019, use a narrative that heavily relies on ecological and social scapegoating to mobilize the affective power of the movies (Plantinga 2013). All these movies convey the message that the world is being cannibalized by predatory profit-seekers and that an alternative world is possible if we have the courage to fight for it. In other words, become good and sustainable by becoming an activist! It also illustrates the emotional power of providing adolescents with a normative orientation (Aerni 2018; Aerni and Oser 2011; Slater 2007).

Even though the movies claim to be based on a "true story" or "investigative journalism", they tend to work more with negative emotional frames than facts.

illustrated in the third picture in the e-book, see https://www.tierwelt.ch/news/unterhaltung/ein-ganzschoen-schlauer-bauer (accessed on 13 October 2020). The authors of "Globi" were collaborating with the Swiss NGO Biovision and it proved to be not just a good story but also good marketing for Swiss-based initiatives to promote organic agriculture. 
Experimental research showed that negatively valenced messages in fact facilitate a stronger relationship between narrative involvement than positively valenced messages, which are processed by a more cognitive route (Cooper and Nisbet 2016). Often, the focus on creating more narrative involvement through negative feelings in research documentaries may also be due to the growing commercial pressure to entertain rather than to inform (Soppe and Pershina 2019).

The negative emotional frames often used to provide a normative orientation in ESD and heavily rely on ecological scapegoating (Schmitt 2019), which tends to entrench rather than overcome stereotypical patterns of reflection on sustainability and limit the potential of solution-oriented cooperation beyond like-minded groups. This may to some extent explain the anti-business rhetoric by Greta Thunberg and other young contemporary activists for social and environmental justice. They largely associate economic growth with environmental disaster, which explains their skepticism about SDG 8 with its implicit suggestion that business must become part of the solution.

\section{1. "Degrowth" as Applied in Agricultural Policies Has Not Led to More Sustainability}

The argument against technology-driven economic change in the degrowth community is very much related to the concept of the agricultural treadmill proposed by Willard Cochrane in 1958 (Cochrane 1958). In a nutshell, Cochrane argued that farmers produce more thanks to economic and technological change. While these productivity increases may benefit consumers due to lower food prices, they would drive farm households into debt and harm the environment. In other words, farming in times of economic globalization would represent a clear case of market failure that requires state intervention. As such, the concept of the agricultural treadmill became the main justification for generous state-support systems for agriculture.

Yet, agricultural subsidies and trade protection turned out to have even more undesirable side effects for the environment because they tended to encourage the overuse of input and monocultural practices (Aerni et al. 2011). It also caused negative consequences for farmers in low-income countries who were not able to compete with the subsidized agricultural exports from high-income countries (Aerni 2011). That is why they are also described as transactions of decline by Jane Jacobs (1984).

In response to these negative side-effects, a system of direct payment has been created in many high-income countries that is meant to decouple farm income from agricultural production and to reward farmers for their other valuable functions in society (e.g., decentralized settlement, environmental stewardship, domestic food 
security) that would not be remunerated by the markets. The concept behind it is called multifunctional agriculture and its makes farmers the recipients of an almost guaranteed income provided by the state (Aerni et al. 2009). As such it is comparable to the universal basic income (UBI), an idea that the degrowth movement envisions for society as a whole to break the "productivist logic" and restore the ability of humankind to engage in meaningful and sustainable work, decoupled from any sort of global market pressure (Ferguson 2013; Seidl and Zahrnt 2019).

However, since the system of direct payments for farmers is still a subsidy, it did not lead to the decoupling of income from production (Aerni 2009). It also failed to make farming more attractive for the young generations (Takayama et al. 2020) and the positive impact on the environment was relatively low, even with the introduction of eco-direct payments (Greer 2017; Whitfield 2006; Dempsey et al. 2020).

\subsection{New Zealand: An Example of Making Business Part of the Solution in Agriculture}

New Zealand, a high-income country where agriculture still matters in economic terms, realized already in the early 1980s, that subsidies for farming will neither save farmers nor will they protect animal welfare or the environment in the long run. Instead, the country remembered the success story of the land grant college system that was established in the United States in the 19th century to address poverty in the countryside. The idea behind it was that a state with limited resources should bring knowledge and investment to the countryside rather than subsidies. In other words, the state should assume the role of a coach rather than a nanny by encouraging more collaboration between research, farming and business and by promoting the new products developed in the domestic agricultural system abroad to increase exports.

Despite problems of agricultural intensification, especially in the increasingly dominant dairy business, agriculture in New Zealand remains overall less extensive than the subsidized agricultural systems in Europe. New Zealand has also become a leader in the development and export of environmental innovation in agriculture (Saunders 2019). As such, the country was able to keep its image in tourism of being "clean and green" while keeping the agricultural sector attractive for the younger generation (Aerni et al. 2009). By reinventing the land grant college idea for the 21st century, the country essentially falsified the Cochrane hypothesis.

What Cochrane failed to realize is the importance of making use of knowledge, the only non-rival resource, to mitigate the impact of agriculture on the environment and to create more value-added for farm products. In other words, knowledge-driven economic and technological change may not always be part of the problem, but can become part of the solution if institutional framework conditions encourage business 
to invest in sustainable innovation that proves to be scalable (Naam 2013). If it does so, then the profits earned are actually important because they signal that investing in sustainable solutions can also be profitable and therefore financially sustainable (Aerni 2009).

\subsection{The Global Knowledge Economy Makes Diversification through Innovation More Inclusive}

Agricultural reform in New Zealand was a sort of natural experiment. It proved that business can be part of the solution in a sector that was largely discounted as the victim of economic globalization. Once agriculture in New Zealand became more open for business under well-designed institutional framework conditions, it also became more diversified, more innovative in the field of sustainable agricultural practices as well as in the creation of new agricultural markets (Saunders 2019). Even improving animal welfare makes economic sense in New Zealand because it is an added value for consumers. Moreover, in view of the mild climate in New Zealand, it makes more economic sense for livestock farmers to let cattle graze outdoors throughout the year and thus largely dispense with energy-intensive indoor management and feeding (Aerni 2009).

What Cochrane did not take into account is that agriculture is not just a commodity business with decreasing returns. If you let farmers, researchers and the state become entrepreneurs who jointly invest in desirable new products and services, then you create diversification through innovation (Etzkowitz and Zhou 2006) resulting in new markets with increasing returns thanks to a specific added value (better for the environment, improved taste, more nutritious, etc.). The New Zealand approach to agriculture proved that this is possible. In this context, the global knowledge economy provides unique business opportunities to make better use of knowledge to create innovation that does not just generate profits for the innovating company but may also create large positive externalities for society and the environment (Aerni 2018).

\section{The Importance of Institutional Framework Conditions to Make Business Part of the Solution}

Institutional framework conditions play a crucial role in efforts to make business part of the solution. Such framework conditions must go beyond the regulation of harmful business activities but encourage a transition in business toward an inclusive low-carbon economy. This would also require a mission-oriented approach in which the state assumes the role of a risk-taking entrepreneur to build the basis 
for the next phase of growth and technological progress (Juma 2016; Mazzucato 2013; Sachs et al. 2019). Even taking into consideration concerns about rebound effects, such an approach may be more effective in addressing global sustainability challenges than merely relying on expensive regulation, subsidies or a universal basic income (UBI) to reduce the negative externalities of harmful business practices and job-displacing innovation (Nabi and Green 2015; Howard et al. 2019; Romer 2010).

A significant number of research publications illustrate how changing institutional framework conditions have induced business to become part of the solution throughout history (Juma 2016; Aerni 2018; Naam 2013; Mazzucato 2013; Nordhaus and Shellenberger 2007; Collier 2018). Moreover, the empirical research by Ester Boserup in Kenya suggested that a region with high population growth rates does not necessarily have to fare worse compared to a region with low-population growth rates (Boserup 1981). After all, it depends on the institutional framework conditions that either encourage or discourage people to explore new forms of environmental resource management. Finally, one of the primary lessons of the 20th century was that the great famines took place almost exclusively in socialist regimes with their focus on protecting agriculture from international trade and promoting self-sufficiency (Boserup 1981; Wemheuer 2014; Nolan 1988).

This past experience with direct payments in agriculture in Europe, the alternative path chosen by New Zealand with its idea of reviving the land-grant college idea and the negative impact of the concept of self-sufficiency on food security in socialist countries is of crucial importance to understand why SDG 8 matters from an empirical perspective. It challenges the normative conceptions popularized by the degrowth movement.

\section{A Universal Basic Income Is Unlikely to Contribute to More Inclusiveness on the Global Level}

Degrowth advocates may see a great potential in addressing SDG 8, Target 5 (SDG 8.5) to guarantee decent work for men and women as well as equal pay for equal value by introducing a UBI on the state level as a way to subsidize work. This may be feasible for high-income countries with a strong economy and a large tax base, but it will have unintended consequences; after all, it will not be affordable to low-income countries that have to create a strong economy in the first place to build up the necessary tax base for funding a UBI. In other words, instead of global inclusive development, a UBI will most likely remain an exclusive privilege of affluent countries. Inadvertently, it may create a two-class society within high-income countries consisting of the privileged citizens who are officially eligible 
for a state-supported UBI, and the migrant workers from low-income countries who do the work that no one wants to do anymore in high-income countries. After all, they will not be eligible for a UBI but actually do the hard work in these affluent societies (Aerni 2016b).

\section{Concluding Remarks}

The UN Sustainable Development Goals (UN SDGs) take into account the past failures and successes in international efforts to cope with global sustainability challenges. One of the major lessons learned from the past is that there is not just market failure, but also state failure. Lots of social and environmental problems are the result of wrong incentives created through government regulation. This was illustrated in this chapter by using the example of agricultural policies in high-income countries and the failure of the international community to address biodiversity loss and climate change in an effective way. In return, it has also been shown that public-private partnerships combined with favorable institutional framework conditions can be quite effective in enabling sustainable change. Examples that illustrate successful cases of collective action are the prevention of the expansion of the ozone hole in the atmosphere and the reduction of polluting emissions in industry.

Sustainable Development Goal 8 (SDG 8) builds upon these insights and recognizes the importance of innovation in enabling inclusive growth, more decent work and a decoupling of economic growth from environmental degradation. In this context, dynamic urban economies play a crucial role as drivers of economic diversification and sustainable change in rural and urban areas alike.

As such, SDG 8 represents a pragmatic and practice-oriented approach that is based on trial and error in the search for scalable solutions. Such solutions may only provide provisional relief since nature and humankind continuously evolve and with it, new challenges emerge that have to addressed with new approaches by future generations (Naam 2013).

SDG 8 also reflects the fact that for the majority of the people on this planet, who live in low- and middle-income countries, poverty rather than affluence is still the main enemy of sustainable development (Hollander 2003).

Economic growth and economic diversification through innovation (SDG 8.1/8.2) are therefore crucial in offering a future for those who cannot invoke any formal rights because they are not formally employed or are economic migrants with hardly any legal protection outside their country of origin. Correspondingly, development policies that support entrepreneurship and formal market development (8.3), investments in the domestic economy that stimulate job creation and reduce 
youth unemployment (8.5/8.6), and policies that protect the economic rights of migrant workers and those in precarious employment (8.8) contribute substantially to the targets of SDG 8 . They are designed to reduce poverty and deprivation through the promotion of more inclusive societies.

In this context, one could argue that achieving the targets of SDG 8 is key to achieving all the remaining goals. After all, if the income of the poorest of the poor improves, their access to essential human rights, such as food, shelter, education, health treatment and political participation are very likely to increase as well. Moreover, empirical evidence, based on Maslow's hierarchy of needs (Maslow 1954; Maslow 1968) shows that once the essential material needs are covered, concern for the future of the next generation and the environment increases too (Winston 2016; Brandt et al. 2015; Jacobs 1994; Wilson 2018). This also explains why almost all the other SDGs contain at least one target that refers to business as part of the solution. ${ }^{17}$

High-income countries in Europe and the United States successfully addressed these existential and material issues associated with targets of SDG 8 at an earlier stage of economic development and are now more concerned with post-material needs (Aerni 2018).

This may explain why the current global discourse on sustainable development, as well as the teaching material used for "Education for Sustainable Development" (ESD) and largely shaped by stakeholders in affluent countries, contains an implicit anti-business rhetoric. The narrative is based on the view that global economic and technological changes primarily serve the needs of business, often at the expense of essential human needs and the environment. This may also explain why normative theories related to "degrowth" are very popular. They imply that each of us can contribute to save the planet by defending our values against business interests, embracing a more frugal lifestyle and by becoming responsible consumers (green consumerism). This normative approach in ESD provides meaning, orientation

17 The following targets refer directly or indirectly to business as part of the solution: SDG 1.4 on economic rights, SDG 2A,D,C on the promotion of agricultural investment and trade, SDG 3C,D on investment in health infrastructure and capacities for managing health risks, SDG 4.4 on promoting skills for entrepreneurship, SDG 5A,B,C on promoting the economic empowerment of women, SDG $7 \mathrm{~B}$ on expanding infrastructure and upgrade technology for supplying modern and sustainable energy services, SDG 9 on promoting sustainable industrialization, SDG 103/6 on empowering economic rights and enhanced representation of developing countries in international economic institutions, SDG 11.3 on inclusive urbanization, SDG 12.6 encourage business to adopt sustainable practices, SDG 14.7 on increasing economic benefits to low-income countries by promoting sustainable fisheries and aquaculture, SDG 15.1 on the promotion of sustainable use of terrestrial ecosystems, SDG 16.3 on promoting the rule of law and equal access to justice and SDG 17 on public-private partnerships. 
and identity in an increasingly complex world, but it may fail to help address the real sustainability challenges of the 21st century, including the current COVID-19 pandemic, because it does not recognize that business is an essential part of society. An effective approach to respond to the growing global challenges cannot consist of asking poor people to stop their plans to provide for a better material future for their children. Instead, the focus should be on the transformation of business into a driver of sustainable and inclusive change and the creation of decent jobs. This is of particular importance in view of the current job losses caused by the COVID-19 pandemic in low-income countries. It is estimated that the pandemic will cause 1.6 million workers in the informal economy to lose their livelihoods. ${ }^{18}$

Recognizing the value of inclusive business for sustainable change may, however, require a change of mindset recognizing that business is always part of, and not apart from, society. Based on this insight, the public discourse as well as classroom discussions on sustainability would be more about realizing opportunities through innovation and less about merely preventing risks through regulation. In order to realize opportunities, the state must provide incentives to induce people to take the risk to invest in an alternative future. This view is endorsed by the UN institution that is generally associated with the voice of the developing world, the United Nations Conference on Trade and Development (UNCTAD). As described in this paper, it endorses the view that business can become part of the solution if effective institutional framework conditions are in place. Such framework conditions mobilize entrepreneurship and innovation for inclusive and sustainable change and discourage environmentally and socially harmful practices, not just in business, but society as a whole. This very practical and pragmatic approach embodies a clear call for a decade of joint action and is likely to be more effective and humane in achieving the UN Sustainable Development Goals than the normative approach, which tends to confuse action with activism.

Funding: This research received no external funding.

Acknowledgments: I would like to thank my colleague Isabelle Schluep for the review and valuable feedback on the manuscript and the late Calestous Juma as the main source of inspiration for this contribution.

Conflicts of Interest: The author declares no conflict of interest.

18 See more numbers on the COVID-19 Impact on SDG 8 on the Website of the Department of Social and Economic Affairs of the United Nations: https://sdgs.un.org/goals/goal8 (accessed on 15 October 2020). 


\section{References}

Aerni, Philipp. 2009. What is sustainable agriculture? Empirical evidence of diverging views in Switzerland and New Zealand. Ecological Economics 68, pp. 1872-82. [CrossRef]

Aerni, Philipp. 2011. Food sovereignty and its discontents. ATDF Journal 8, pp. 23-40.

Aerni, Philipp. 2013. Resistance to agricultural biotechnology: The importance of distinguishing between weak and strong public attitudes. Biotechnology Journal 8, pp. 1129-32. [CrossRef] [PubMed]

Aerni, Philipp. 2015a. Entrepreneurial Rights as Human Rights. Cambridge: Banson.

Aerni, Philipp. 2015b. The Sustainable Provision of Environmental Services. From Regulation to Innovation. CSR, Sustainability, Ethics and Governance Series; Cham: Springer.

Aerni, Philipp. 2016a. Coping with Migration-Induced Urban Growth: Addressing the Blind Spot of UN Habitat'. Sustainability 8, p. 800. [CrossRef]

Aerni, Philipp. 2016b. Das bedingungslose Grundeinkommen als Taschengeld für die postmaterielle Wertegemeinschaft'. Austrian Institute Paper. Available online: http: //austrian-institute.org/das-bedingungslosegrundeinkommen/ (accessed on 3 November 2020).

Aerni, Philipp. 2018. Global Business in Local Culture: The Impact of Embedded Multinational Enterprises. Berlin: Springer.

Aerni, Philipp. 2019a. Politicizing the Precautionary Principle: Why disregarding facts should not pass for farsightedness. Frontiers in Plant Science. [CrossRef] [PubMed]

Aerni, Philipp. 2019b. The Use and Abuse of the Term 'GMO' in the 'Common Weal Rhetoric' against the Application of Modern Biotechnology in Agriculture'. In Ethical Tensions from New Technology: The Case of Agricultural Biotechnology. Edited by James Harvey. Wallingford: CABI Publishing, pp. 39-52.

Aerni, Philipp. 2020. The Industrious City as an Ecosystem. In The Industrious City. Edited by Hiromi Hosoya and Markus Schaefer. Zürich: Lars Müller Publishers, pp. 105-15.

Aerni, Philipp, and Thomas Bernauer. 2006. Stakeholder attitudes towards GMOs in the Philippines, Mexico and South Africa: The issue of public trust. World Development 34, pp. 557-75. [CrossRef]

Aerni, Philipp, Allan Rae, and Bernard Lehmann. 2009. Nostalgia versus Pragmatism? How attitudes and interests shape the term sustainable agriculture in Switzerland and New Zealand. Food Policy 34, pp. 227-35. [CrossRef]

Aerni, Philipp, Christian Häberli, and Baris Karapinar. 2011. Reframing Sustainable Agriculture. In The Prospects of International Trade Regulation: From Fragmentation to Coherence. Edited by Thomas Cottier and Panagiotis Delimatsis. Cambridge: Cambridge University Press.

Aerni, Philipp, and Fritz Oser, eds. 2011. Forschung verändert Schule. Zurich: Seismo Verlag. Aerni, Philipp, Karin Nichterlein, Stephen Rudgard, and Andrea Sonnino. 2015. Making Agricultural Innovation Systems (AIS) Work for Development in Tropical Countries. Sustainability 7, pp. 831-50. [CrossRef] 
Alyaz, Yunus, Erkan Isigicok, and Esim Gursoy. 2016. The impact of the environmental documentary movies on pre-service German teachers' environmental attitudes. Journal of Education and Training Studies 5, pp. 159-70. [CrossRef]

Arts, Karin. 2017. Inclusive sustainable development: A human rights perspective. Current Opinion in Environmental Sustainability 24, pp. 58-62. [CrossRef]

Aryeetey, Ernest. 2015. The informal economy, economic growth and poverty in sub-Saharan Africa. In Economic Growth and Poverty Reduction in Sub-Saharan Africa: Current and Emerging Issues. Edited by Andrew McKay and Erik Thorbecke. Oxford: Oxford University Press, pp. 159-96.

Autio, Minna, Eva Heiskanen, and Visa Heinonen. 2009. Narratives of 'green'consumers-The antihero, the environmental hero and the anarchist. Journal of Consumer Behaviour: An International Research Review 8, pp. 40-53. [CrossRef]

Barbier, Edward, and Joanne Burgess. 2019. Sustainable development goal indicators: Analyzing trade-offs and complementarities. World Development 122, pp. 295-305. [CrossRef]

Beck, Ulrich. 1986. Risikogesellschaft. Berlin: Suhrkamp.

Bird, Kate. 2019. Addressing Spatial Poverty Traps. Working Paper, Chronic Poverty Advisory Network based at the Overseas Development Institute, London, UK. Available online: https://www.un.org/development/desa/dspd/wp-content/uploads/sites/22/2019/ 02/Spatial-poverty-traps-by-Kate-Bird.pdf (accessed on 3 November 2020).

Boarini, Romina, Asa Johansson, and Macro Mira d'Ercole. 2006. Alternative Measures of Well-Being. Paris: OECD.

Boserup, Ester. 1981. Population and Technological Change: A Study of Long-Term Trends. Chicago: University of Chicago Press.

Bosse, Jana. 2019. Die Gesellschaft verändern: Zur Strategieentwicklung in Basisgruppen der deutschen Umweltbewegung. Zurich: Transcript Verlag.

Brandt, Yannick, Szabolcs Nagy, Anda Radu, and Svenja Katharina Wiemer. 2015. Human Rights Approach to Industrialization in the Context of the Sustainable Development Goals. Vienna: Regional Academy of the United Nations (RAUN).

Braungart, Richard G., and Margaret M. Braungart. 1990. Youth movements in the 1980s: A global perspective. International Sociology 5, pp. 157-81. [CrossRef]

Carant, Jane Briant. 2017. Unheard voices: A critical discourse analysis of the Millennium Development Goals' evolution into the Sustainable Development Goals. Third World Quarterly 38, pp. 16-41. [CrossRef]

Casidy, Riza, Catherine Prentice, and Walter Wymer. 2019. The effects of brand identity on brand performance in the service sector. Journal of Strategic Marketing 27, pp. 651-65. [CrossRef] 
Clark, William, Jill Jäger, Jeannine Cavender-Bares, and Nancy M. Dickson. 2001. Acid Rain, Ozone Depletion, and Climate Change: An Historical Overview. Learning to Manage Global Environmental Risks. Cambridge: MIT Press, vol. 2, pp. 21-39.

Cochrane, Willard Wesley. 1958. Farm Prices, Myth and Reality. Minneapolis: University of Minnesota Press.

Collier, Paul. 2018. The Future of Capitalism. London: Penguin Books.

Cooper, Kathryn E., and Erik C. Nisbet. 2016. Green narratives: How affective responses to media messages influence risk perceptions and policy preferences about environmental hazards. Science Communication 38, pp. 626-54. [CrossRef]

Costanza, Robert, Ralph d'Arge, Rudolf De Groot, Stephen Farber, Monica Grasso, Bruce Hannon, Karin Limburg, Shahid Naeem, Robert Vincent O'Neill, and Jose Paruelo. 1997. The value of the world's ecosystem services and natural capital. Nature 387, pp. 253-60. [CrossRef]

Dempsey, Jessica, Tara G. Martin, and Ussif Rashid Sumaila. 2020. Subsidizing extinction? Conservation Letters, 12705. [CrossRef]

Devereux, Stephen. 2000. Famine in the Twentieth Century. IDS Working Paper 105, IDS, Brighton, MI, USA.

European Commission (EC). 2002. Communication from the Commission on the Precautionary Principle, COM (2000) 1 Final. Brussels: European Commission.

European Environmental Bureau (EEB). 2019. Decoupling debunked-Evidence and arguments against Green Growth as a Sole Strategy for Sustainability. Report, Brussels. Available online: https://eeb.org/library/decoupling-debunked/ (accessed on 3 November 2020).

Etzkowitz, Henry, and Chunyan Zhou. 2006. Triple Helix twins: Innovation and sustainability. Science and Public Policy 33, pp. 77-83. [CrossRef]

Eysenck, Michael William. 1990. Happiness: Facts and Myths. Hove: Psychology Press.

Fadeeva, Zinaida, and Yoko Mochizuki. 2010. Competences for sustainable development and sustainability. International Journal of Sustainability in Higher Education, pp. 391-402. Available online: www.emeraldinsight.com/1467-6370.htm (accessed on 3 November 2020).

Ferguson, Peter. 2013. Post-growth policy instruments. International Journal of Green Economics 7, pp. 405-21. [CrossRef]

Fernbach, Philip, and Steven Sloman. 2017. The Knowledge Illusion. London: Penguin Random House Audio Publishing Group.

Fiorini, Ann. 1998. The End of Secrecy. Foreign Policy 111, pp. 50-63. [CrossRef]

Foley, Jonathan. 2017. Living by the lessons of the planet. Science 356, pp. 251-52. [CrossRef] [PubMed]

Folke, Carl, Reinette Biggs, Albert Norström, Belinda Reyers, and Rockström Johan. 2016. Social-ecological resilience and biosphere-based sustainability science. Ecology and Society 21, p. 41. [CrossRef] 
Frey, Diane F. 2017. Economic growth, full employment and decent work: The means and ends in SDG 8. The International Journal of Human Rights 21, pp. 1164-84. [CrossRef]

Gehlen, Arnold. 1988. Man. New York: Columbia University Press.

Gerold, Stefanie. 2019. Neubewertungen von Arbeit: Vielfalt von Tägigkeiten ermöglichen und kombinieren. In Tätigsein in der Postwachstumsgesellschaft. Edited by Irmi Seidl and A. Angelika Zahrnt. Niederweimar: Metropolis Verlag, pp. 59-73.

Goldstein, Anna, Claudia Doblinger, Erin Baker, and Laura Díaz Anadón. 2020. Startups supported by ARPA-E were more innovative than others but an investment gap may remain. Nature Energy. [CrossRef]

Gottlieb, Robert. 1993. Reconstructing environmentalism: Complex movements, diverse roots. Environmental History Review 17, pp. 1-19. [CrossRef]

Greer, Alan. 2017. Post-exceptional politics in agriculture: An examination of the 2013 CAP reform. Journal of European Public Policy 24, pp. 1585-603. [CrossRef]

Global Sustainable Development Report (GSDR). 2019. The Future Is Now-Science for Achieving Sustainable Development, prepared by the Independent Group of Scientists appointed by the United Nations Secretary-General. United Nations. Available online: https://sustainabledevelopment.un.org/gsdr2019 (accessed on 13 October 2020).

Haberl, Helmut, and Karl-Heinz Erb. 2017. Land as a planetary boundary: A socioecological perspective. In Handbook on Growth and Sustainability. Cheltenham: Edward Elgar Publishing, pp. 277-300.

Hardt, Michael, and Antonio Negri. 2011. The fight for 'real democracy' at the heart of Occupy Wall Street. Foreign Affairs 11, pp. 301-20.

Hickel, Jason, and Giorgos Kallis. 2019. Is Green Growth Possible? New Political Economy 25, pp. 469-86. [CrossRef]

Hidalgo, César. 2015. Why Information Grows: The Evolution of Order, from Atoms to Economies. New York: Basic Books.

Hirsch, Karen, and Matt Nisbet. 2007. Documentaries on a Mission: How Nonprofits Are Making Movies for Public Engagement. Future of Public Media Project Report. Available online: https://cmsimpact.org/resource/documentaries-on-a-mission-how-nonprofitsare-making-movies-for-public-engagement/ (accessed on 3 November 2020).

Hirschman, Albert Otto. 1992. Rival Views of Market Society and other Recent Essays. Cambridge: Harvard University Press.

Hollander, Jack M. 2003. The Real Environmental Crisis: Why Poverty, Not Affluence, Is the Environment's Number One Enemy. California: University of California Press.

Holt-Giménez, Eric, and Miguel A. Altieri. 2013. Agroecology, food sovereignty, and the new green revolution. Agroecology and Sustainable Food Systems 37, pp. 90-102.

Hosoya, Hiromi, and Markus Schaefer, eds. 2020. The Industrious City: Urban Industry in the Digital Age. Zürich: Lars Müller Publishers. 
Howard, Michael W., Jorge Pinto, and Ulrich Schachtschneider. 2019. Ecological Effects of Basic Income. In The Palgrave International Handbook of Basic Income. London: Palgrave Macmillan, pp. 111-32.

International Labour Office (ILO). 2014. Transitioning from the Informal to the Formal Economy. International Labour Conference, ILC 103/V/1. Geneva: ILO.

Jackson, Tim. 2009. Prosperity without Growth: Economics for a Finite Planet. Abingdon: Routledge. Jackson, Tim. 2019. The post-growth challenge: Secular stagnation, inequality and the limits to growth. Ecological Economics 156, pp. 236-46. [CrossRef]

Jacobs, Jane. 1969. The Economy of Cities. Vintage. New York: Random House.

Jacobs, Jane. 1984. Cities and the Wealth of Nations. Vintage. New York: Random House.

Jacobs, Jane. 1994. Systems of Survival: A Dialogue on the Moral Foundations of Commerce and Politics. Vintage. New York: Random House.

Juma, Calestous. 1994. Promoting international transfer of environmentally sound technologies: The case for national incentive schemes. Green Globe Yearbook of International Co-operation on Environment and Development, pp. 137-48.

Juma, Calestous. 2011. The New Harvest: Agricultural Innovation in Africa. Oxford: Oxford University Press.

Juma, Calestous. 2016. Innovation and Its Enemies: Why People Resist New Technologies. Oxford: Oxford University Press.

Juma, Calestous, and Lee Yee-Cheong. 2005. Innovation: Applying Knowledge in Development. London: Earthscan, vol. 14.

Kaiser, Jacquelin, Thomas Roth, and Isabelle Campo Schluep. 2012. Grüne Wirtschaft: Wachstum bei erschöpfbaren natürlichen Ressourcen. Die Volkswirtschaft 85, p. 19.

Kalb, Martin. 2002. "Rather Active Today than Radioactive Tomorrow!” Environmental Justice and the Anti-Nuclear Movement in 1970s in Wyhl. West Germany. Global Environment 5, pp. 156-83. [CrossRef]

Kallis, Giorgos, Christian Kerschner, and Joan Martinez-Alier. 2012. The Economics of Degrowth. Amsterdam: Elsevier.

Kallis, Giorgos, Vasilis Kostakis, Steffen Lange, Barbara Muraca, Susan Paulson, and Matthias Schmelzer. 2018. Research on degrowth. Annual Review of Environment and Resources 43, pp. 291-316. [CrossRef]

Kioupi, Vasiliki, and Nikolaos Voulvoulis. 2019. Education for sustainable development: A systemic framework for connecting the SDGs to educational outcomes. Sustainability 11, p. 6104. [CrossRef]

Kowasch, Matthias, and Daniela Franziska Lippe. 2019. Moral impasses in sustainability education? Empirical results from school geography in Austria and Germany. Environmental Education Research 25, pp. 1066-82. [CrossRef]

Langewand, Alfred. 1999. Kontextanalyse als Methode der pädagogischen Geschichtsschreibung. Zeitschrift für Pädagogik 45, pp. 505-19. 
Latouche, Serge. 2007. Petit traité de la Décroissance Sereine. Paris: Mille et une Nuits.

Latouche, Serge. 2010. Editorial to the Special Issue on De-Growth. Journal of Cleaner Production 18 , pp. 51-52.

Lipset, Seymour Martin, and William Schneider. 1983. The decline of confidence in American institutions. Political Science Quarterly 98, pp. 379-402. [CrossRef]

Love, Joseph LeRoy. 1980. Raul Prebisch and the origins of the doctrine of unequal exchange. Latin American Research Review 15, pp. 45-72.

Luomala, Harri, Petteri Puska, Merja Lähdesmäki, Marjo Siltaoja, and Sami Kurki. 2020. Get some respect-buy organic foods! When everyday consumer choices serve as prosocial status signaling. Appetite 145: 104492. [CrossRef] [PubMed]

MacFeely, Steve. 2019. The big (data) bang: Opportunities and challenges for compiling SDG indicators. Global Policy 10, pp. 121-33. [CrossRef]

Mäder, Jörg A., Jenö Staehelin, Thomas Peter, Damian Brunner, Harald E. Rieder, and Werner A. Stahel. 2010. Evidence for the effectiveness of the Montreal Protocol to protect the ozone layer. Atmospheric Chemistry and Physics 10, pp. 12161-71. [CrossRef]

Maslow, Abraham Harold. 1954. Motivation and Personality. New York: Harper.

Maslow, Abraham Harold. 1968. Toward a Psychology of Being. New York: John Wiley and Sons.

Masood, Ehsan. 2016. The Great Invention the Story of GDP and the Making and Unmaking of the Modern World. New York: Pegasus Books.

Mazzucato, Mariana. 2013. The Entrepreneurial State: Debunking Public vs. Private Sector Myths. London: Anthem.

McCourt, Willy. 2018. Lost in translation: The World Bank and the Paris Declaration. Development Policy Review 36, pp. 649-68. [CrossRef]

McDonough, William, and Michael Braungart. 2013. The Upcycle: Beyond SustainabilityDesigning for Abundance. New York: Macmillan.

Meadows, Donella Hager, Dennis Lynn Meadows, Jørgen Randers, and William Wohlsen Behrens. 1972. The limits to growth. New York 102, p. 27.

Miller, Daniel. 2001. The poverty of morality. Journal of Consumer Culture 1, pp. 225-43. [CrossRef]

Moisander, Johanna. 2007. Motivational complexity of green consumerism. International Journal of Consumer Studies 31, pp. 404-9. [CrossRef]

Naam, Ramez. 2013. The Infinite Resource: The Power of Ideas on a Finite Planet. Lebanon: University Press of New England.

Nabi, Robin L., and Melanie C. Green. 2015. The Role of a Narrative's Emotional Flow in Promoting Persuasive Outcomes. Media Psychology 18, pp. 137-62. [CrossRef]

Nabi, Robin L., Abel Gustafson, and Risa Jensen. 2018. Framing climate change: Exploring the role of emotion in generating advocacy behavior. Science Communication 40, pp. 442-68. [CrossRef]

Nolan, Peter. 1988. The Political Economy of Collective Farms. Cambridge: Polity Press. 
Nordhaus, Ted, and Michael Shellenberger. 2007. Break through: From the Death of Environmentalism to the Politics of Possibility. Boston: Houghton Mifflin Harcourt.

Orlitzky, Marc, and Manjit Monga. 2018. Virtue Signaling. In Integrity in Business and Management. Routledge Studies in Business Ethics, Band 13. Milton Park: Taylor and Francis.

Overmann, Jörg, and Amber Hartman Scholz. 2017. Microbiological research under the Nagoya Protocol: Facts and fiction. Trends in Microbiology 25, pp. 85-88. [CrossRef]

Paech, Niko. 2012. Befreiung vom Überfluss: Auf dem Weg in die Postwachstumsökonomie. München: Oekom Verlag.

Plantinga, Carl. 2013. The affective power of movies. In Psychocinematics: Exploring Cognition at the Movies. Edited by Arthur P. Shimamura. Oxford: Oxford University Press, pp. 94-111.

Prathapan, K. Divakaran, Rohan Pethiyagoda, S. Kamaljit Bawa, Peter H. Raven, and Priyadarsanan Dharma Rajan. 2018. When the cure kills-CBD limits biodiversity research. Science 360, pp, 1405-6. [CrossRef]

Prins, Gwyn, and Steve Rayner. 2007. Time to ditch Kyoto. Nature 449, pp. 973-75. [CrossRef]

Rai, Shirin M., Benjamin D. Brown, and Kanchana N. Ruwanpura. 2019. SDG 8: Decent work and economic growth-A gendered analysis. World Development 113, pp. 368-80. [CrossRef]

Rangan, Haripriya. 2000. Of myths and Movements: Rewriting Chipko into Himalayan History. London: Verso.

Raworth, Kate. 2012. A safe and just space for humanity: Can we live within the doughnut. Oxfam Policy and Practice: Climate Change and Resilience 8, pp. 1-26.

Rieckmann, Marco. 2017. Education for Sustainable Development Goals: Learning Objectives. Paris: UNESCO Publishing.

Rifkin, Jeremy. 1990. The Green Lifestyle Handbook: 1001 Ways to Heal the Earth. New York: Henry Holt and Co.

Rifkin, Jeremy. 2014. The Zero Marginal Cost Society: The Internet of Things, the Collaborative Commons, and the Eclipse of Capitalism. New York: St. Martin's Press.

Rockström, John, and Mattias Kulm. 2015. Big World Small Planet: Abundance within Planetary Boundaries. New Haven: Yale University Press.

Romer, Paul Michael. 1990. Endogenous technological change. Journal of Political Economy 98, Pt 2, pp. 71-102. [CrossRef]

Romer, Paul Michael. 2010. What parts of globalization matter for catch-up growth? American Economic Review 100, pp. 94-98. [CrossRef]

Ruzek, William. 2015. The informal economy as a catalyst for sustainability. Sustainability 7, pp. 23-34. [CrossRef]

Sachs, Jeffrey D. 2015. The Age of Sustainable Development. New York: Columbia University Press. 
Sachs, Jeffrey D., Guido Schmidt-Traub, Mazzucato Mariana, Dirk Messner, Nebojsa Nakicenovic, and Johan Rockström. 2019. Six transformations to achieve the sustainable development goals. Nature Sustainability 2, pp. 805-14. [CrossRef]

Saunders, Caroline. 2019. Sustainable agriculture-Life beyond subsidies: Lessons from New Zealand. Journal of Agricultural Economics 70, pp. 579-94. [CrossRef]

Schaefer, Markus. 2020. The Industrious City in Switzerland. In The Industrious City. Edited by Hiromi Hosoya and Markus Schaefer. Zürich: Lars Müller Publishers, pp. 24-43.

Scheyvens, Regina, Glenn Banks, and Emma Hughes. 2016. The private sector and the SDGs: The need to move beyond 'business as usual'. Sustainable Development 24, pp. 371-82. [CrossRef]

Schmitt, Casey R. 2019. Scapegoat Ecology: Blame, Exoneration, and an Emergent Genre in Environmentalist Discourse. Environmental Communication 13, pp. 152-64. [CrossRef]

Schwab, Klaus. 2015. The fourth industrial revolution: What it means and how we should respond. Foreign Affairs, December 12.

Seidl, Irmi, and Angelika Zahrnt, eds. 2019. Tätigsein in der Postwachstumsgesellschaft. Niederweimar: Metropolis Verlag.

Šik, Ota. 1976. The Third Way: Marxist-Leninist Theory and Modern Industrial Society. White Plains: International Arts and Sciences Press.

Sikkink, Kathryn. 2019. Evidence for Hope: Making Human Rights Work in the 21st Century. Princeton: Princeton University Press.

Slater, Michael D. 2007. Reinforcing spirals: The mutual influence of media selectivity and media effects and their impact on individual behavior and social identity. Communication Theory 17, pp. 281-303. [CrossRef]

Soppe, Birthe, and Raissa Pershina. 2019. Melting icebergs vs. spectacularization: Storytelling of conflicting institutional demands in wildlife documentaries. In Microfoundations of Institutions. Edited by Patrick Haack, Jost Sieweke and Lauri Wessel. Bingley: Emerald Publishing Limited.

Stavins, Robert N. 1995. Transaction costs and tradeable permits. Journal of Environmental Economics and Management 29, pp. 133-48. [CrossRef]

Stefánsson, Hlynur Orri. 2019. On the limits of the precautionary principle. Risk Analysis 39, pp. 1204-22. [CrossRef] [PubMed]

Stoll, Georg. 2019. Arbeit in Schwellen- und Entwicklungsländern. In Tätigsein in der Postwachstumsgesellschaft. Edited by Irmi Seidl and Angelika A. Zahrnt. Niederweimar: Metropolis Verlag, pp. 227-53.

Takayama, Taisuke, Noboru Hashizume, and Tomoaki Nakatani. 2020. UNCTAD (2015) Entrepreneurship for Sustainable Development. Report prepared for the Secretary General. General Assembly of the United Nations (A/71/210), 26 July 2016. Available online: https://unctad.org/meetings/en/SessionalDocuments/a71d210_en.pdf (accessed on 3 November 2020). 
UNCTAD. 2014a. Entrepreneurship for Sustainable Development. Report prepared for the Secretary General. General Assembly of the United Nations (A/71/210). Geneva: United Nations.

UNCTAD. 2014b. Science, Technology and Innovation Capability Gaps, Policy Environment, and Evolving Policy Tools for Sustainable Development. Trade and Development Board (TD/B/C.II/MEM.4/5). Geneva: United Nations.

UNCTAD. 2018. Achieving the UN Sustainable Development Goals in the Least Developed Countries. A Compendium of Policy Options (UNCTAD/ALDC/2018/4). Geneva: United Nations.

Victor, Peter. 2008. Managing without Growth: Slower by Design, Not Disaster. Cheltenham: Edward Elgar Publishing.

Vivero-Pol, Jose Luis, Tomaso Ferrando, Olivier De Schutter, and Ugo Mattei, eds. 2018. Routledge Handbook of Food as a Commons. Abingdon: Routledge.

Wemheuer, Felix. 2014. Famine Politics in Maoist China and the Soviet Union. London: Yale University Press.

Whitfield, John. 2006. Agriculture and environment: How green was my subsidy? Nature 439, pp. 908-9. [CrossRef]

Wilson, Clive C. 2018. The purpose of humanity. In Designing the Purposeful World. Abingdon: Routledge.

Winston, Christine N. 2016. An existential-humanistic-positive theory of human motivation. The Humanistic Psychologist 44, p. 142. [CrossRef]

Winter, Christine. 2007. Education for sustainable development and the secondary curriculum in English schools: Rhetoric or reality? Cambridge Journal of Education 37, pp. 337-54. [CrossRef]

Wright, Christopher, and Daniel Nyberg. 2019. Climate change and social innovation. In Handbook of Inclusive Innovation. Edited by Gerard George, Ted Baker, Paul Tracey and Havovi Joshi. Cheltenham: Edward Elgar Publishing.

Zürn, Michael. 1998. The rise of international environmental politics: A review of current research. World Politics 50, pp. 617-49. [CrossRef]

(C) 2021 by the author. Licensee MDPI, Basel, Switzerland. This article is an open access article distributed under the terms and conditions of the Creative Commons Attribution (CC BY) license (http://creativecommons.org/licenses/by/4.0/). 



\section{Memories of a Practitioner: Ciba-Geigy Crop Protection Activities in Indonesia in the 1980s, an Example of Local Embeddedness}

\section{Dino Sozzi}

\section{Introduction}

In this chapter, I draw on my experience as a crop scientist and former manager for Ciba-Geigy and in later years its legacy companies Novartis and Syngenta. ${ }^{1}$ My aim is to demonstrate the connectivity between the commercial activities of the global company Ciba-Geigy in developing economies such as Indonesia, and the concurrent transfer of useful soft skills and good practices to local society and specifically farmers, eventually resulting in a more efficient use of scarce natural resources, new local economic ecosystems and the creation of new jobs. The chapter sets the stage with a description of the situation after World War II, with its challenges of food security around the globe.

In Indonesia, Ciba-Geigy's crop protection business model profited from this set-up of industrialized agriculture that was pushed by the so-called "Green Revolution", an international initiative mainly sponsored by public sector institutions to address the global food security challenges in view of rapid population growth. The company won large contracts with the Indonesian Government, to deliver and apply by aircraft rather indiscriminately crop protection products over vast tracts of land. The owners of the fields, typically small rice farmers with holdings of $0.5-1$ hectares of paddy land, were not really involved in the process. While the "Green Revolution" approach certainly helped overcome the rice production deficit and rendered Indonesia self-sufficient in rice production by 1985, it became obvious in the early 1980s that this "one treatment fits all" policy had a number of serious

1 Ciba-Geigy was formed in 1970 by the merger of J. R. Geigy Ltd. (founded in Basel in 1758) and CIBA (founded in Basel in 1859) (pharmaphorum). The merged company was mainly active in pharmaceuticals, textile auxiliaries, and plant protection agents. In 1996, Sandoz, the other Basel-based pharmaceutical company, and Ciba-Geigy merged to form Novartis (pharmaphorum). In the year 2000, the agro business divisions of both Novartis and AstraZeneca (Swedish-British pharmaceutical company) were divested to create Syngenta that produces agrochemicals and seeds and is based in Basel. Since 2017, Syngenta has been owned by ChemChina, a Chinese state-owned enterprise. 
draw-backs. While farmers were mostly seen as, and pushed to be, rather passive adopters of subsidized products and technologies, the government faced increasing budget constraints that eventually made the subsidies unaffordable. Other negative side effects of this public-sector-driven approach to agricultural modernization were the overuse of agrochemicals and fertilizers, and the replacement of many traditional rice varieties by few high-yielding varieties that encouraged monocultural practices and increased the risk of new pest outbreaks.

Once the Indonesian Government decided to put a stop to all agrochemical subsidies, Ciba-Geigy was forced to rethink its business strategy. As a consequence, the company eventually discovered the farm household as the new direct customers for a sustainable business and commenced to engage with its members in its very own interest. This started with local initiatives such as farmer Field Days for thousands of individual small farmers in Indonesia in the 1980s, followed by the development of the Farmer Team Concept by Bill Vorley in the 1990s, eventually leading to the "Good Growth Plan", announced by Syngenta in 2013. While, in the 1980s in Indonesia, Farmer Field Days seemed to be the obvious thing to do from a local business perspective, Ciba-Geigy was still a long way from recognizing the company's global corporate responsibility that eventually led to the "Good Growth Plan" 25 years later. Two years thereafter, in 2015, the Sustainable Development Goals (SDGs) were published by the United Nations General Assembly, many of which were anticipated by and reflected in Syngenta's "Good Growth Plan", aimed at sustainably managing its business.

\section{The Green Revolution}

World War II had transformed the global geopolitical, economic and social landscape. On the political side, borders were moved, new countries were created, political systems were overturned and the "traditional" colonial systems of economic exploitation got under pressure and started to shift. Economically, globalization in its modern, capitalistic form started to rapidly expand, supported by advanced production capacities developed during the wartime experience and technological advancement, such as the development of shipping containers or airline systems. And socially, with the adoption of the Universal Declaration of Human Rights by the 
United Nations General Assembly in 1948 (General Assembly Resolution 217 A) a new guideline towards a more humane world was adopted. ${ }^{2}$

Yet, the geopolitical situation after World War II was also characterized by the growing confrontation between the United States and the Soviet Union. The resulting Cold War was also a battle over the hearts and minds in the so-called non-aligned states, representing mostly developing countries in the Global South that were on the verge of embracing communism, believing that it would address the concerns of the poor in a more effective way. The United States responded to this challenge, among others, by launching a global initiative, which was later called the 'Green Revolution' (Gaud 1968), to enhance agricultural productivity and improve food security in non-aligned tropical countries. The aim was to demonstrate that the capitalistic system was more effective in feeding a growing population and lifting people out of poverty. The main promoter of the Green Revolution was Henry Wallace, Vice-President of the United States under F.D. Roosevelt, who launched the Mexican Agricultural Program with the support of the Rockefeller Foundation. Its purpose was to promote agricultural modernization on the basis of the latest breeding technologies, application of industrially produced fertilizers and the use of modern crop protection, catapulting productivity of cereals and later rice way beyond the typical one to two percent annual yield progress. In this context, it was the American Plant Breeder Norman Borlaug who set the first milestone in the genetic improvement of wheat in Mexico, by introducing more productive and resistant semi-dwarf varieties that were made more daylight insensitive through shuttle breeding, to be more adapted to different latitudes. His approach was then replicated in Asia for rice. The introduction of the Dee-Gee-Woo-Gen (DGWG) dwarfing gene into tall varieties of indica rice at the International Rice Research Institute (IRRI) in the Philippines (Swaminathan 2009) resulted in high-yielding varieties that responded well to irrigation and fertilizer application and were less prone to falling over (lodging) (Hargrove and Coffman 2006). Rice production in Indonesia, for example, increased from 12 million tons in the early 1960s to 44 million tons in 1989 (Ricepedia 1989); yields increased from 1.76 metric tons per hectare (t/ha) in 1961 to 4.25 t/ha in 1989, equivalent to an annual yield increase of more than eight percent (calculated from data on Ricepedia).

2 General Assembly resolution 217 A was proclaimed by the United Nations General Assembly in Paris on 10 December 1948. Available at: https://www.un.org/en/universal-declaration-human-rights/ (accessed 9 May 2020). 
The Green Revolution proved wrong the pessimists who argued that population growth would outpace growth in agricultural production and thus lead to famine and starvation, as reported by the economist Thomas Robert Malthus who predicted this scenario already at the beginning of the 19th century. But it also had its downsides since it encouraged monocultural practices with all its undesirable side-effects for the environment and agrobiodiversity (Gómez et al. 2013). So, while Borlaug has contributed considerably to save millions of people from starvation and certainly deserved his Nobel Peace Prize, his approach also created environmental and with it socioeconomic issues when applied on a large scale. In response to these shortcomings of the Green Revolution, a paradigm shift took place after the end of the Cold War. With the fall of the Iron Curtain (Iron Curtain refers to the border between Soviet influenced Eastern Europe and democratic Western Europe before 1989) in 1989 and the UN Conference on Environment and Development (UNCED) in Rio in $1992,{ }^{3}$ the focus moved away from the narrow production paradigm, more towards a systemic approach to agricultural development that also takes into account the exhaustion of resources, and the threat to biodiversity and the environment, from human agricultural activities.

In response to this paradigm shift, "Sustainable Management" started to show up in the agendas of political organizations and corporate meetings. Early discussions were heavily biased towards the economic component and it took time for politicians and top managers to accept the simple reality that the social and environmental components in the discussions were of equal importance. In spite of early recognition that urgent actions were needed, it took another 25 years until the SDGs were approved by the United Nations General Assembly in 2015, getting rid of the defensive attitude and accepting that the focus on economic development was the main component for the slow progress on sustainability. And here my story goes back to Indonesia.

\section{Rice Production in Indonesia}

In view of the success with Borlaug's high-yielding wheat varieties in Mexico and India, the International Rice Research Institute (IRRI) was founded in the Philippines to replicate the success for rice cultivation. It was established with the support of the Governments of the United States and the Philippines and mainly financed by the

3 Rio de Janeiro Earth Summit was a major United Nations conference held in Rio de Janeiro in June, 1992, to align Member States on common goals and international cooperation on development issues after the Cold War. 
Rockefeller and Ford Foundations. The rice genetic program was led by Te Tzu Chang (1927-2006), a prominent Shanghai-born agricultural and environmental scientist. He had first studied agriculture and horticulture at the Nanking University, received an MSc from Cornell in 1954 and a PhD in plant genetics from the University of Minnesota in 1959. He is the father of IR8, the first "Green Revolution" rice variety released into South East Asian (SEA) countries in 1966 (Hargrove and Coffman 2006). IR8 was a cross of PETO, then the most important Indonesian tall rice variety, with DGWG, an important Taiwanese dwarf variety (Hargrove and Coffman 2006). ${ }^{4}$ IR8 was followed by a number of improved IR varieties, such as IR36 and IR64, both with Rice Brown Plant Hopper (BPH, Nilaparvata lugens) resistance. At the time (1960s), Indonesia was the world's largest rice importer and depended heavily on supply from mostly regional neighbors such as Vietnam or Thailand, but still the average supply of calories was way below basic requirements (personal information). Rice shortages were then part of the general economic malaise that contributed to the fall of President Sukarno in 1966 (Coleman et al. 2007). The new regime under General Suharto (1967 to 1998) decided that economic development must have precedence over all else (Coleman et al. 2007). The first priority was to invest in the productivity of food crops such as rice, the primary staple food, to achieve self-sufficiency (Manning 1987). Suharto saw the big advantage of the industrial approach to rice growing and forced Indonesian farmers to abandon their traditional forms of agriculture (Manning 1987). This in turn leads to the erosion of local rice growing and religious traditions, more dependence on seed, fertilizer and crop protection suppliers and started to fundamentally change the very traditional Indonesian society (Manning 1987). These changes were very much in the intention of the Pancasila doctrine which had been proposed by Sukarno and followed by Suharto, ${ }^{5}$ to move Indonesia away from

4 "IR8-288-3 - which was eventually named variety IR8-was a semi-dwarf rice, about $120 \mathrm{~cm}$ tall with strong stems that held the plant upright, even when heavily fertilized. It was also non-sensitive to photoperiod, or day length, scientists would later learn. That meant it could be grown in many latitudes, at any time of the year" (Hargrove and Coffman 2006, p. 37).

5 "Pancasila is the official, foundational philosophical theory of Indonesia. It had been presented first in 1945 by Sukarno to the Investigating Committee for Preparatory Work for Independence (Badan Penyelidik Usaha Persiapan Kemerdekaan (BPUPK)) and defined the five principles of Pancasila" (Schindehütte 2006). "The principles include: 1. Indonesian patriotism; 2. Internationalism emphasizing justice and the virtue of humanity; 3. Deliberative consensus emphasizing a form of representative democracy in which ethnic dominance is absent and each member of the council possesses equal voting power; 4 . Social Welfare premised on the theory of the welfare state and emphasizing popular socialism, and; 5 . A Divinity that is an ultimate unity (a formulation that can be seen as implying both monotheism or pantheism, thereby allowing space for all of Indonesia's major religions)" (Schindehütte 2006). 
its historic colonial structure towards becoming a modern society and independent nation (the five principles include: nationalism, internationalism, democracy, social prosperity, belief in god), to lead Indonesia out of its colonial history and become a "modern" society (Schindehütte 2006).

Suharto understood well that cheap rice was key for political stability and thus gave high priority to rice production. Despite continuing rice shortages and price increases in the early years of his regime, its success in obtaining large amounts of foreign aid for rice imports and in rehabilitating BULOG (Badan Urusan Logistik, the rice purchasing and price stabilization agency made directly responsible to Suharto) began to show results as rice prices (and the general cost of living index) began to stabilize in the late 1960s (Timmer 1975, pp. 212-16). BULOG's purpose of providing food security mostly to government staff was extended to become the safety stock holder and most important rice trader in Indonesia. This included import and export management, rice stock management and price guarantees. BULOG thus became politically very important to stabilize the emerging modern society of city dwellers, albeit generally at the cost of the traditional society of (rice) farmers

The most significant factor in the increase in output and productivity of rice was the rapid spread of high-yield rice varieties (Hargrove and Coffman 2006). They were promoted together with subsidized fertilizer, pesticides, and credit through the "mass guidance" or BIMAS (Bimbingan Masal) rice intensification program (Manning 1987). This extension program also offered technical assistance to farmers unfamiliar with the new cultivation techniques. Government investments in irrigation had also made a significant contribution to increased rice production in Indonesia, also allowing a second paddy crop to be grown during the dry season (Manning 1987). The BIMAS program, besides being an outlet for heavily subsidized fertilizers and crop protection products, was setting up public extension services in the form of teaching and training programs for farmers, designed to help adapt modern rice growing techniques into the traditional Indonesian village structure. In this context, young students spent time in remote villages, educating farmers on more advanced rice growing practices. In 1969, the Jatiluhur irrigation project was started to irrigate 240,000 hectares of rice around Cikampek, in the highly fertile coastal plain of North Java, one hundred kilometers east of Jakarta. This project is related to my former activities at Ciba-Geigy in Indonesia.

\section{Ciba-Geigy's Original Business Model}

These heavy investments in improved infrastructure and rice production systems paid off well for Indonesia, leading eventually to rice self-sufficiency in 1985 
(Manning 1987), stopping the currency from further devaluation. For farmers, the change was fast, drastic and often difficult to understand and follow. Ciba-Geigy, at the time an important supplier of crop protection products to Indonesia's BIMAS system, decided to become more active in this lucrative market and Ciba-Pilatus (a collaboration of CIBA Agro and PILATUS Stans) was founded in $1959,{ }^{6}$ with the aim to commercially apply crop protection products. While active in other counties as well (e.g., Sudan for cotton), Ciba-Pilatus started to work in Indonesia from a small air field in Karawang, half way between Jakarta and Cikampek, in the fertile Jatiluhur irrigation zone, to treat rice, in close cooperation with government organizations. This worked well for Ciba-Pilatus and went on throughout the 1960s and into the 1970s, with financially good results, probably some questionable business models and definitely not much discussion with individual farmers.

At the time, Ciba-Geigy opened a small experimental field station in Cikampek, to support their activities. In the late 1970s, with farmers being better trained, the government wanting more independence from international companies and indiscriminate aerial application becoming too costly, the spraying activities of Ciba-Pilatus were ceased. Ciba-Geigy, however, continued to sell large quantities of crop protection products to the Indonesian Government. Consequently, the small experimental field station in Cikampek became Ciba-Geigy's first science-driven agricultural experimental station in South East Asia in 1978. As of 1982, with the appointment of my predecessor Rudolf Guyer, ${ }^{7}$ the first expatriate leading scientist at the station, Ciba-Geigy started to heavily invest in the site, developing an up-to-date infrastructure and introducing modern field trialing and management methods. Most work at the time was dedicated to traditional herbicide and insecticide development mainly in rice, and, around the time when I arrived, activities were extended to also

6 The Ciba-Pilatus Aerial Spraying Co. of Switzerland utilized for many years, besides other aircraft types, the Pilatus PC-6 Porter STOL (Short Takeoff and Landing) utility aircraft which had been equipped with spraying equipment (https://de.wikipedia.org/wiki/Pilatus_PC-6, accessed on 10 May 2020).

7 Rudolf Guyer (1953-), a Swiss citizen with a MS in agronomy from ETH Zurich, Switzerland and a $\mathrm{PhD}$ in weed science from the University of Hohenheim, Germany, worked for Ciba-Geigy and its follower companies Novartis and Syngenta from 1978 until 2008 in various R\&D and commercial functions. He managed the Indonesian R\&D organization of Ciba-Geigy from 1982 to 1986. He later established the crop protection industry organization CropLife Africa Middle East and served as their Director from its establishment in 2002 until 2017. Today, he is an independent agricultural consultant, offering his experience in crop protection and project management through his firm AgriConsult AG, based in Bülach, Switzerland. 
include fungicide and biocontrol products, and covering additional crops such as corn and vegetables.

\section{Business Model Adaptation}

During that same period, the Rice Brown Plant Hopper (BPH), originally a minor issue in rice due to broad genetic resistance in the local varieties, had become a major problem, which led to the introduction of the above-mentioned BPH resistant varieties IR36 and IR64. In a short time, however, BPH resistance broke down and the pest developed into a real problem. As was soon understood, this was due to resurgence, a phenomenon where the heavy use of broad spectrum insecticides such as the prevalent OP's (Organo-Phosphate insecticides) at the time, certainly would kill the pest but at the same time also killed most of the over one hundred known predators of $\mathrm{BPH}$, leading to a hyper fast recovery of $\mathrm{BPH}$ in absence of any natural enemies. With this knowledge in mind, the Indonesian government stopped the supply to farmers of heavily subsidized and therefore overused insecticides, as of 11 November $1986 .^{8}$

For Ciba-Geigy, this meant that the existing simple business model of selling large quantities of pesticides to the Government became obsolete overnight. As a consequence, the time of easy catering to one large customer (i.e., the Government) was over and in due time the roughly 30 million individual Indonesian farmers became the new focus of attention in Ciba-Geigy's Indonesian business.

\section{Embeddedness Effects}

In retrospect, the government decision was very sensible, not only to get rid of the heavy financial burden for the subsidies, but also to take care of all the corruption typically ensuing such a regulated set-up (Manning 1987). On top, this allowed rice management practices to be pushed towards Integrated Pest Management (IPM) principles, relying on a variety of methods to limit pesticide use for the control of insects, plant diseases and rodents. Not least, such a development allowed farmers to regain some of the individual responsibility to manage their own affairs, that had been stripped off from them during the whole "development" process.

While the woes in Ciba-Geigy were mostly in our marketing and sales organization as the company had lost its one customer and sales went from close

8 For more information see https://www.cbd.int/financial/fiscalenviron/indonesia-subsidyfuel.pdf (accessed on 10 May 2020). 
to USD 100 million per annum to less than USD 5 million overnight, Research and Development (R\&D) suffered a lot less of a set-back, as this part of the organization had a given spending budget that was not tied to the country sales and at the time did also include a lot of work for other South East Asian (SEA) countries. Already under the leadership of Rudolf Guyer, the Cikampek station had started to collaborate with a nearby government-run rice research facility, even though they were mostly concerned with rice breeding. The first field days for farmers were organized in late 1982, where we invited local and regional farmers to visit our trials and explain to them the opportunities and risks of crop protection products in their fields.

A typical field day would include about 200-250 farmers that were taken in small groups through several different stations in the course of a day, including safe handling of crop protection products, correct field application, demonstration of crop protection products, explanation of IPM principles, followed by a general discussion which was usually very lively. While these field days clearly had a marketing perspective to overcome the government's decision to stop supplying pesticides and were aimed at establishing Ciba-Geigy as a supplier of crop protection products at the farmer level, this was also the first time in Indonesia that we started to interact with rice farmers directly. ${ }^{9}$ The fact that we had a well-established field trialing station allowed us to do product development work and invite visitors to demonstrate to them the results of our work.

It became clear very quickly that safe handling of crop protection products and IPM principles were the major topics that needed to be addressed. This started with the safe storage of chemicals, not an easy task in a one- or two-room bamboo house without locks, or the use of labelled bottles, as often the local dealers would buy a large bottle and repack it into small soft drink bottles, with the obvious risk of accidental misuse. Applying the right amount of product in the right way and at the right time (this included determination of treatment thresholds based on insect counts) was another teaching topic, as the "more is better" attitude was prevalent among farmers, historically driven by the availability of cheap subsidized agrochemical products. And not least the use of some very simple protective measures such as the use of face masks, rubber boots and washing after application were taught.

Throughout the 1980s and early 1990s, we usually had two farmer field weeks per year, one in the dry season and one in the wet season, that were attended by over

9 At the time, foreign companies had no right to directly sell products in the country and had to go through local importers and distributors. Only technical activities (i.e., R\&D) were exempt from this rule. 
25,000 farmers over the twelve-year period. This does not seem to be a lot in view of the 30 million farmers in Indonesia at the time. But most of these farmers, many of them from Java but some coming also from other islands, especially Sumatera, were village elders/leading farmers that had great influence on the behavior of other farmers at home. Upon returning from the field day, which often was a great event in their life, they would sit on their bale (a kind of large local sofa) in front of their house in the evening and educate their neighbors in the community, as it has been the tradition in the Indonesian rural society, thus multiplying our efforts to many more farmers. Often, upon visiting a village to look at trials, somebody would come up to me, recounting the learnings and experience they had made on the field days.

Besides the farmer field days, every season we offered two to three internships to excellent agronomy students, which were proposed by their professors from key agricultural universities, such as Gadjah Mada in Yogyakarta or the agricultural Universities in Padang or Medan. They were selected by my close collaborator Marjudin Kusnawiria, a senior Indonesian agronomist and plant pathologist in my team, who had excellent connections into the local academic environment. Typically, they were doing a small project, including field trials, under the supervision of the various Ciba-Geigy specialists at the Cikampek station. For the students, this was an extraordinary experience, being able to learn modern trialing technologies, to connect with experienced Cikampek staff and working with an infrastructure which at the time was usually not available at the universities. How important such an experience was for these young people I only realized many years later. While on a field visit to an oil palm plantation in Medan in 2012, more than 20 years after having worked in Indonesia, a middle-aged man who was part of the plantation management team came up to me and profusely thanked me for the opportunity he was given in the 1980s to do an internship at Cikampek, which he said had been a crucial experience in his career.

Obviously, our R\&D staff, all together between 20-25 people, were also part of the embeddedness effects. Besides the fact that they were paid quite well, including a health and pension plan, which at the time was far from being standard in the country, they regularly travelled in Southeast Asia and beyond. Being experts with international exposure (at the time a rare experience in Indonesia), they became sought after specialists in their country.

We also hired daily laborers on a seasonal basis, typically about 50-100 people from neighboring villages. While they had relatively low salaries, the equivalent of USD 50-150 per month, it did bring into the local economy a steady stream of cash and allowed many children to go to school properly fed, dressed and equipped 
with the necessary books which had to be provided by the parents. When building a second station at Lembang, in the highlands of Bandung, earth work totaling over 2000 cubic meters, was done by hand. It was marginally more expensive than using a bulldozer, but it provided 100 jobs for a whole year to local villagers and prevented destroying the delicate volcanic soils structure of the site by heavy equipment.

The most memorable part of my time in Indonesia started, when Bill Vorley came to join me for a year (1988-1989). ${ }^{10}$ He was an IPM expert and had joined Ciba-Geigy shortly before. I spent many evenings in his house in Cikampek, where we enjoyed lengthy discussions over a cold Bintang beer, talking about the development of small farmer agriculture in Indonesia and comparable economies. I was not very knowledgeable at the time about IPM or sustainability ("Sustainability" was just starting to become a word of the standard vocabulary, as a consequence of the Brundtland Report, (Brundtland 1987)) and learnt many things from him which would later influence my own thinking. He was an unorthodox practitioner and thinker and led an experimental program on our station, focusing on IPM approaches for rice pest control. To locally make best use of our trial data and with his deep knowledge of IPM, he sat together with a dalang (a traditional Indonesian shadow puppet player) and scripted an educational story on how to properly grow rice in a modern, IPM driven way. The wayang kulit (literally leather puppet) show was then played in many villages around the station and enjoyed very much by the village communities, as a piece of entertainment that at the same time was very educational. And I remember that sometimes, when I was invited for a meal in a modest farmers hut, the kids would challenge their father to wash his hands before the meal, referring to what the "Good Farmer" in the puppet show had taught them.

\section{Discussion}

Even though the word embeddedness had been coined by Karl Polanyi (1886-1964) already in the middle of last century, I was not even aware of its existence when I was working in Indonesia, let alone its application to our activities there as a large global company that was essentially present to do business transactions. Embeddedness, as a term and as an inherent part of corporate activities in a specific

10 Bill Vorley (1957-), a UK citizen with a Bachelor in Applied Biology from the University of Bradford, UK, and a PhD in Applied Ecology from the University of Southampton, UK, worked for Ciba-Geigy from 1985 until 1994 and was part of the Indonesian R\&D team, 1988-1989. He is presently linked to the IIED (International Institute for Environment and Development, London, UK) as a Senior Associate and works as an independent consultant from his home in East Sussex, UK. 
economy, only came to my attention recently, when working on joint projects with the Center of Corporate Responsibility and Sustainability (CCRS) at the University of Zurich (Aerni 2018; Schluep 2019). It made me reflect on my times in Indonesia, at a time when the local economy was still very traditional and most people neither had the education nor the experience and understanding of how to make use of what a global player, represented in their economy, could offer them, beyond strictly transactional business.

To be fair, even I did not really see or reflect much on the soft potential of what my company could offer to the local economy. It was more of a spontaneous approach, originally driven by business needs and probably to some extent influenced by my experience as a student, reflecting the "Zeitgeist" of the 1960s. Moreover, looking back, I would probably be more critical of the rather opportunistic approach of Ciba-Geigy in selling whatever governments wanted to buy in countries like Indonesia. But, in retrospect, everyone eventually learns and becomes smarter. Multinational companies must generate revenues and the way they earn them largely depends on the institutional setting, which they themselves cannot really influence.

Nevertheless, Ciba-Geigy, with its embedded commercial activities in Indonesia, had some lasting positive effects on the local society and economy, also thanks to the changing institutional setting at the end of the Cold War. Here are just some of the most obvious examples:

It started with the building of an R\&D team of locally educated people who then were exposed to a global network of agricultural experts, within and outside of the company, vastly expanding their knowledge, experience and exposure to "other" ways of running business, doing research and connecting to the farming economy. They were closely connected to local academia through presentations and lectures to students and the internship programs, thus passing on their expanded personal experience to a whole generation of young Indonesian agricultural students. And I remember well the coaching sessions in proper Indonesian behavior and language I received from the team before giving my first lecture on fungicide resistance management to a body of students at the prestigious Gadjah Mada University in Yogyakarta.

A second important effect of the company's activities was the injection of cash into the rural societies around our stations. It may have been, relative to the size of the country, a small token, but for the local communities it made a big difference, especially in helping children's schooling efforts. While schooling was compulsory and free, parents often struggled to pay for the school uniforms and books as these were cash out items. 
A third effect was our close interaction with the farmers. Field days were always the highlight of the season, for the commercial team to prepare the list of invitees, for the R\&D team to set up the program and prepare the show trials and lectures, and, of course, for the farmers who were selected to come to our research station in Cikampek, as it often meant a refreshing break from their daily life activities in the village. I was always impressed by their intrinsic knowledge of rice growing, their keen interest to learn, and their ability to listen and observe. They were also very active participants in the discussions and brought up many critical and interesting questions, despite the fact that many of them had only limited formal education. Personally, I believe that these field days were our most lasting and effective way of connecting with the farmers and teaching them new insights into rice growing and crop protection.

Of course, there were many other companies that left their imprint on Indonesia's economy at the time. My chapter is a very personal reflection on the most challenging and interesting time in my early career and how I experienced it through my company. It demonstrates that a company can contribute to decent work and inclusive growth through local embeddedness, which is an inherent component of any commercial activity pursued by a global company that sets up business in a particular economic environment. It is in the self-interest of the company to collaborate with local stakeholders and ensure that they co-benefit from corporate investment. A commitment to local embeddedness is especially beneficial in a developing country context, in which the transfer of soft knowledge and behavior can be a stimulus to the local people and economy, way beyond the core of the transactional part of business. My experience in Indonesia taught me many important things about fruitful local collaboration, which I could later use again while working in Latin America and Africa, as many of these farming communities were facing very similar issues and were very open and keen to any kind of educational stimulus.

\section{Aftermath and Outlook}

My personal experience in Indonesia was not unique. Similar learnings had been collected by Ciba-Geigy collaborators in other parts of the developing world. Coincidently, there was growing pressure on the chemical industry, notably after the explosion of Union Carbide's Bhopal plant in India in 1984 and the Sandoz warehouse fire in Schweizerhalle, Switzerland, in 1986. Driven by public pressure and supported by in-house learnings, there was growing recognition at the company leadership level of the importance of corporate responsibility and sustainable business management. 
Ciba-Geigy under the leadership of Dr. Alex Krauer, ${ }^{11}$ then President of the Board, developed its Vision 2000 where the "triple bottom line" responsibility of economy, environment and society was introduced for the first time (Vorley 2013). While the strategy certainly was a step in the right direction, introduced through an extensive collaborator training program and aimed at supporting an open dialogue with the public, it was never incorporated to its full extent due to internal policy swings. It was also focused too narrowly on efficiency increases as well as waste reduction in production.

An equally important step toward a more responsible business behavior was the establishment of the Farmer Support Team (FST) in 1991 in Ciba-Geigy's Crop Protection business, under the leadership of Bill Vorley. It was financed with CHF 2 million annually and its aim was to support and train small farmers in the developing world of Africa, Asia and Latin America, obviously with the intention to gain new customers, but just as much in the innovative spirit around the Vision 2000 to transfer knowledge and capabilities designed to make farmers more familiar with "environmental and ethical product stewardship" (Vorley 2013) and advanced methods in integrated pest management. While the project was not yet holistically aimed at promoting sustainable agriculture at the time, it was the first time in the company that a realistic and serious attempt had been started to address the problems of small holders in the developing world. In spite of Vorley's convincing arguments and hard work and dedication to the project, progress was slow and the project was under constant pressure from the more conservative faction of our organization. Not surprisingly, Vorley left the company in 1994, frustrated over the slow progress and continuous confrontations. Obviously, while these first attempts for a change in thinking were made in Ciba-Geigy, the time for a breakthrough was just not ripe yet.

While working in Colombia in the late 1990s though, I was lucky to have a strong FST in place and relied heavily on it for small farmer education and training, late proof of the solid base that had been laid out by Vorley. In the same years, it was decided to phase out all the highly toxic OP's, which at the time were the company's main-stay insecticides. The decision was controversially received and with all the good intention at the time, it eventually took about 20 years to actually reach this goal. Another aspect of the changing attitude in Ciba-Geigy was an increased focus on biological products which culminated in the acquisition of Bioline AgroSciences Ltd.,

11 Dr. Alex Krauer (1931-), economist from Basel, Paris and London School of Economics, PhD in Political Sciences from the University of Basel, was a longstanding Ciba-Geigy manager and President of the Board at Ciba-Geigy 1987-1996. 
Colchester, UK in 1992. The business developed nicely over the years, but always constituted only a small portion of Ciba-Geigy's agrobusiness. This was not really due to a lack of interest but rather the complexity of the biologicals business and the incompatibility with our chemicals business model.

After the formation of Syngenta in 2000, sustainable farming and small farmers became a growing point of interest for the company's agribusiness, not least because there remained a large vacuum for the technification of agriculture in developing economies, including a substantial business potential. And there were also business opportunities in the developed world around the sustainable management of agriculture under the pressure of growing regulatory constraints and increasing customer expectations. In 2008, the first "Forum for the Future of Agriculture (FFA)" was held in Brussels by Syngenta, together with the European Landowner's Organization, to "create an open platform, where all stakeholders interested in contributing to a more sustainable agriculture system could come together and debate and share knowledge and expertise on how this could be achieved" (Forum For Agriculture 2020). The FFA constituted the start of a real breakthrough in Syngenta, where sustainability issues in agriculture, problems of farming communities and consequences for society at large were publicly addressed and discussed. The learnings from these meetings, not least the strong public reaction to this "coming out" of Syngenta eventually led the company into the launch of its "Good Growth Plan" in 2013. ${ }^{12}$ The plan's six key focus points are:

- Make crops more efficient

- Rescue more farmland

- Help biodiversity flourish

- Empower small holders

- Help people stay safe

- Look after every worker

With the "Good Growth Plan", Syngenta as the legacy company to Ciba-Geigy for the first time introduced a fully integrative plan for the sustainable management of its business and the relationship with its customers. The plan, introduced in 2013, has been successful and achieved its challenging goals by 2020, well within its set targets. The plan is in line with Syngenta's corporate responsibility position, and

12 For more information see https://www.syngenta.com/sustainability/good-growth-plan; accessed on 14 June 2020. 
its execution was monitored and audited by external stakeholders. It aligns very well with the United Nation's SDGs and fully encompasses SDG 8, decent work and inclusive growth. So, finally, fifty years after starting to recognize the risks and downsides of the "Green Revolution's" industrial approach to agriculture, public (SDGs) and private (Good Growth Plan) sectors have aligned around agreed base principles of how an agricultural business has to be managed, not only from its strictly economic, transactional aspect, but also from the local embeddedness perspective to contribute to inclusive and sustainable growth and decent work, especially in developing countries.

\section{Conclusions}

Looking back to almost 40 years of working in Ciba-Geigy and its legacy companies, I only realize today how we were often caught by the moment, around an exciting idea, a breakthrough or an opportunity, and at the same time blind to the bigger context, or the consequences and impact on society at large. I do not want this to be understood as negative critique or outright condemnation of the approaches we took at Ciba-Geigy (or for that matter the industry at large). It is simply the recognition in hindsight of how much we are all caught in the zeitgeist of societal norms and limits, our wishes and projections, and our excitement.

Corporations are set up to earn money, not to resolve societal problems. They will change over time as they recognize direct negative consequences for their business, when societal norms move or laws (typically driven by the societal change) force them into new behaviors. This was the case with labor laws in the 19th century, sustainability in the late 20th century and climate change in the early 21st century. In this context, the UN SDGs, with their emphasis on global partnerships, constitute a great joint effort to further incentivize industry to contribute to sustainable change.

Education: During my educational years in the 1960s and 1970s, a time of massive change, driven by the experience of a global war and its consequences, the essential driver was economic growth. The recognition of the limits of unabashed growth was at best dawning, sustainability was not a goal and compartmentalized thinking was the norm. Meanwhile, full employment and decent work were highly politicized terms embedded in the narratives of the two ideologies of the Cold War.

What we need today is a change in education in two critical areas: (1) A consequent move from learning in compartments to learning that promotes connectivity and contextual thinking, addressing risk and its consequence for the environment and societal integration at all school levels. I am aware, of course, that this is to some extent wishful thinking, limited by financial and political constraints, 
but I am convinced that it would constitute a useful long-term investment that would benefit society, business and the environment alike. (2) Introduction of integrated management, leadership and responsibility training at all levels of higher education. This would give young leaders the vocabulary and base understanding of the inherent virtues of SDG 8 and positively affect individual and corporate behavior in the long term.

Corporate: Financial goals are and remain critical when managing companies. But there is more acceptance today of the fact that environmental and societal aspects are integral parts of corporate management and many companies have embedded them in their corporate strategy. Unfortunately, this process of recognition was rather slow and consequential action even slower, often only under huge societal/legal pressure. Additionally, views on how to politically integrate sustainable development goals, including SDG 8, into societies, laws and education differ greatly across the globe. In the long term, this issue can only be addressed by a dual strategy which relies on (1) consequent integration of SDG-8-related topics into the educational systems at all levels and (2) societal pressure (legislation and consumer behavior) to hold corporations responsible for their commitment to sustainable and inclusive change. In reality, we have to accept that such changes will never come overnight. Effects of educational approaches take at least a generation to become effective and societal changes tend to be rather slow, as proven by the SDGs which were approved by the United Nations in 2015 only, although first recognition of the underlying issues goes back to the 1950s and 1960s. We also have to accept that individual corporations will respond differently to the expectations of society. Legal consequences have to be applied systematically and have to bite to bring up the laggers and deniers.

Society: Societal processes are slow and cumbersome, driven by recognition of critical facts and their acceptance and integration into behavior over time. Smart leaders and visionaries at all levels can speed up change, just as much as conservative thinkers and or profit oriented opportunists may slow it down, for economic or political reasons. In view of the odds of all nations agreeing to a common base, the adoption of the SDG principles seems like a miracle and is a crucial step in the right direction. The UN SDGs have become a global reference point at all levels for corporations to design their strategic goals and corporate responsibility plans, for NGO's to reference progress and point out deficits, for political structures to align around and converge on common goals, for nations to design their legal frames and for global organizations to hold each other responsible.

A critical societal issue that slows the roll-out of SDGs is the economic divergence within and across nations. Affluent nations can "afford" to be more sustainable but 
at the same time they are the biggest consumers, while the poorer nations remain essentially focused on economic growth, just to fulfill the minimum of SDG 8 goals. There is clearly a responsibility but more and more also a self-interest of the developed nations to support the less affluent world in developing through investments in inclusive and sustainable change and thus contributing to a fairer sharing of wealth. An awareness of the need to preserve our natural resource base in order to secure the future of mankind will, in the end, be the critical driver for this process. So, while the SDGs are a leap in the right direction, it will probably be another generation before they are truly embedded in society and broadly adopted. However, the fact that they exist is a great advantage to educate the younger generation against a set of globally agreed principles that should drive sustainable and inclusive growth.

Author Contributions: The article was conceived and written exclusively by the author, based on memory, personal experience and some internet research.

Funding: This research received no external funding.

Acknowledgments: The author would like to thank Philipp Aerni and Isabelle Schluep for critical reading, helpful inputs and comments.

Conflicts of Interest: The author is a retired, independent consultant and declares no conflict of interest.

\section{References}

Aerni, Philipp. 2018. Global Business in Local Culture, the Impact of Embedded Multinational Enterprises. SpringerBriefs in Economics. Basel: Springer.

Brundtland, Gro Harlem. 1987. Our Common Future, the Brundtland Report. Published by the United Nations. Oxford: Oxford University Press.

Coleman, Peter, Selwyn Cornish, and Peter Drake. 2007. Suharto's Indonesia. In Arndt's Story: The Life of an Australian Economist. Canberra: ANU Press, pp. 265-73. Available online: www.jstor.org/stable/j.ctt24h3vr.30 (accessed on 10 May 2020).

Forum For Agriculture. 2020. The Forum for the Future of Agriculture. Available online: https://www.forumforagriculture.com/press/ (accessed on 14 June 2020).

Gaud, William S. 1968. The Green Revolution: Accomplishments and Apprehensions. AgBioWorld. March 6. Available online: http://www.agbioworld.org/biotech-info/topics/ borlaug/borlaug-green.html (accessed on 9 May 2020).

Gómez, Miguel I., Christopher B. Barrett, Terri Raney, Per Pinstrup-Andersen, Janice Meerman, André Croppenstedt, Brian Carisma, and Brian Thompson. 2013. Post-green revolution food systems and the triple burden of malnutrition. Food Policy 42, pp. 129-38. [CrossRef] 
Hargrove, Tom, and W. Ronnie Coffman. 2006. Breeding History. Rice Today. October-December. pp. 35-38. Available online: http://www.goldenrice.org/PDFs/ Breeding_History_Sept_2006.pdf (accessed on 9 May 2020).

Manning, Chris. 1987. Public Policy, Rice Production and Income Distribution: A Review of Indonesia's Rice Self-Sufficiency Program. Southeast Asian Journal of Social Science 15, pp. 66-82. [CrossRef]

Ricepedia. 1989. Ricepedia.org. Montpellier, France: CGIAR, Consultative Group for International Agricultural Research. Available online: http://ricepedia.org/indonesia (accessed on 9 May 2020).

Schindehütte, Matti J. 2006. Zivilreligion als Verantwortung der Gesellschaft. Religion als politischer Faktor innerhalb der Entwicklung der Pancasila Indonesiens. Dissertation Universität Hamburg. Available online: https://ediss.sub.uni-hamburg.de/volltexte/2006/ 2915/ (accessed on 10 May 2020).

Schluep, Isabelle. 2019. Prinzipienorientierte Einbettung als Beitrag der Unternehmen $\mathrm{zu}$ nachhaltigem und inklusivem Wachstum. In Herausforderungen für das Nachhaltigkeitsmanagement. Edited by C. Arnold, S. Keppler, H. Knödler and M. Reckenfelderbäumer. Wiesbaden: Springer Gabler.

Swaminathan, Monkombu. 2009. Norman E. Borlaug (1914-2009). Nature 461, p. 894. [CrossRef]

Timmer, Charles Peter. 1975. The Political Economy of Rice in Asia: Indonesia. Food Research Institute Studies 14, pp. 197-231.

Vorley, William. 2013. Two: Reconciling shareholders, stakeholders and managers: Experiencing the Ciba-Geigy vision for sustainable development. In Agribusiness and Society: Corporate Response to Environment, Market Opportunities and Public Regulations. Edited by Business and Economics, Kees Jansen and Sietze Vollena. London: Zed Books.

(C) 2021 by the author. Licensee MDPI, Basel, Switzerland. This article is an open access article distributed under the terms and conditions of the Creative Commons Attribution (CC BY) license (http://creativecommons.org/licenses/by/4.0/). 



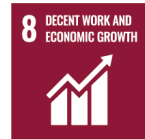

\section{Multilevel Sustainability Tensions of MNEs in Developing Countries}

\section{Lia Ferrini}

\section{Introduction}

On the 24th of April 2013 at 08:45 in the morning in Dhaka District, Bangladesh, an eight-floor commercial building, known as Rana Plaza, collapsed due to a structural failure. The building contained apartments, banks and clothing factories, which produced ready-made garments $(\mathrm{RMG})^{1}$ for major Western clothing brands (BBC 2013). With 1134 deaths and 2500 injuries, the Rana Plaza incident was classified as the deadliest structural failure accident in modern human history (Chowdhury 2017). The tragic accident received global attention, raising awareness of Corporate Social Responsibility (CSR) across global value chains (GVCs).

When the RMG industry first emerged in Bangladesh in the 1980s, it represented one of the key sectors, which contributed to employment creation, poverty alleviation and empowerment of women. However, as the sector expanded, it started to face several challenges regarding compliance with international standards to ensure workplace safety and adequate working conditions for its employees. This happened for several reasons, among them the political and social instabilities of the country (Barua and Ansary 2017).

The expansion of the RMG industry in Bangladesh exemplifies challenges associated with the achievement of Sustainable Development Goal (SDG) 8, which argues for "economic growth with full employment and decent work for all" (United Nations General Assembly 2015, p.14). The consolidation of the human right to decent work and economic growth is complex, especially in the challenging context of developing countries. In these countries, the expectation to generate economic growth can undermine compliance to human rights, especially for local small and medium enterprises (SMEs) producing for GVCs.

The achievement of SDG 8 is strongly associated with the activities of multinational enterprises (MNEs). MNEs that operate in GVCs can represent a

1 The ready-made garment industry (RMG) refers to the finished textile product from clothing factories (OECD 2018). 
major resource for developing countries by boosting inclusive growth, creating better job opportunities and consequently reducing poverty (World Bank 2019). On the other hand, the expansion of these economic giants has to go hand in hand with compliance with international rights and duties along the value chain. Only if this is pursued correctly can MNEs facilitate the integration of international standards in the local ecosystem of SMEs in developing countries and act as successful drivers for economic growth and decent work.

From a wider perspective, challenges faced by transnational actors such as MNEs, reflect the broader complexities of pursuing a global development agenda in diverse local socio-economic contexts. This is the case for Agenda 2030, which has at its core the 17 Sustainable Development Goals (SDGs). Despite the inclusive nature of the SDGs, the different domains that are covered and their global range make the implementation of the ambiguous goals not always straightforward, resulting in synergies but also conflicts between and within the goals (Nilsson et al. 2016).

The implementation of global standards and goals is translated into the firm's business-level, through the adoption of its own Corporate Social Responsibility practice and guidelines. These need to adhere to international, as well as country-level expectations.

The multidimensionality of these tensions that MNEs are faced with in pursuing a globally established sustainability agenda cannot be avoided because it is inherent in the nature of transnational organizations. This raises substantial questions on how to achieve such inclusive and sustainable growth when faced with complexities stemming from the global, local and organizational level?

A first step to tackle this question lies in the understanding of the multidimensional complexities faced by MNEs. Given these premises, the following chapter gives an overview of the triangular relationship between global ethical standards, local contexts and CSR guidelines faced by MNEs operating in developing countries, with a perspective on tensions happening in and between the three levels. The emphasis of the chapter is deliberately on tensions, given the contested nature of the topic.

The aim of the review is synthesized in the following research question:

What is the current understanding of the triangular relationship, between global ethical standards, the local context and CSR guidelines, faced by multinational enterprises operating in developing countries?

The first consultation of the literature revealed that few studies deal with the three dimensions (global-local-organizational) simultaneously, but rather examine the 
tensions between global standards and the local context or on the firm level separately. To bring together these three dimensions, the chapter has been structured as follows: The next section explains the method that was employed to consult the literature. Part 3 of the chapter builds on the background for the review. It illustrates the contribution of MNEs towards sustainable development and how this is positioned in the overall discussion on the SDGs. Sections 4 and 5 present the results of the review of international business ethics literature drawing on the debate on business ethics and culture in cross-cultural contexts and trade-offs in CSR. After these three descriptive units, a critical analysis of these two debates is presented in Section 6. Hereby, literature gaps and corresponding avenues for future research are suggested. The chapter concludes by presenting the main contributions and limitations of the review.

\section{Method}

The literature pool addressing ethical considerations of MNEs operating in developing countries is extremely wide and diversified in terms of disciplinary contribution. Given the ethical focus on business, an international business ethics perspective was considered the most appropriate to narrow down the review to relevant articles.

The identification of relevant articles was pursued with in-depth research in a sector-specific journal on international business ethics that possesses a comparatively high impact factor score considering comparable journals (Journal of Business Ethics). In addition, a more general search was run on Web of Science, JSTOR and Google Scholar using the following research strings: multinational enterprises (MNEs), Corporate Social Responsibility (CSR), international standards, local, cross-cultural, developing country, sustainability, trade-off, tension, and conflict.

All articles were screened for relevance based on a reading of the abstracts followed by the papers themselves. In the abstract review, articles were assessed for their relevance on the topic and included in the review if they fulfilled the following criteria: (1) take an international business ethics perspective towards MNEs operation in developing countries, (2) focus on ethical tensions faced by MNEs operating in cross-cultural contexts, (3) take a critical perspective on the concept of CSR and its country variances, and (4) deal with relevant theories connected to the previous points. Key publications in the field were retrieved with snowball consultations of references. 
From a total of ninety screened articles, ${ }^{2}$ eighteen were selected for review by applying the previously mentioned criteria: respectively, nine articles discussing the relationship between business ethics and culture in cross-cultural contexts, as well as nine articles on trade-offs in CSR. ${ }^{3}$

In this first phase of the review, the concepts of multinational enterprise and Corporate Social Responsibility were defined, as they are relevant for gaining a consistent understanding of the topic. A multinational enterprise is denoted as "that [company which] engages in foreign direct investment (FDI) and owns or, in some way, controls value-added activities in more than one country" (Dunning and Lundan 2008, p. 3). ${ }^{4}$ Given the societal relevance of MNEs' activity and their role in the international context, the definition of Corporate Social Responsibility by the European Commission is suggested. This describes CSR as "the responsibility of enterprises for their impact on society. Respect for applicable legislation, and for collective agreements between social partners, is a prerequisite for meeting that responsibility. To fully meet their corporate social responsibility, enterprises should have in place a process to integrate social, environmental, ethical, human rights and consumer concerns into their business operations and core strategy in close collaboration with their stakeholders" (European Commission 2011, p. 6). ${ }^{5}$

Finally, to endow the reader with a complete picture, it is considered necessary to provide a "working definition" of sustainable development. Conscious of the great debate around the meaning of such an all-encompassing topic, sustainable development is defined following the Brundtland tradition as the "development that meets the needs of the present without compromising the ability of future generations to meet their own needs" (WCED 1987). ${ }^{6}$

2 On Google Scholar, screening of articles was narrowed to the first thirty articles, filtered by relevance with the research strings.

3 In respect to the articles sample, there is awareness that the number of examined articles is limited; however, there is also confidence that the definition of specific criteria enabled a focus on the most relevant articles. Additionally, this review aims to give an overarching perspective on literature in the three dimensions and is not intended to represent an exhaustive elaboration of literature addressing this topic.

4 In business management literature, the term multinational enterprise (MNE) is sometimes used interchangeably with multinational corporation (MNC). In this chapter, the first is adopted following the definition by Dunning and Lundan (2008).

5 COM (2011) 681 final.

6 The author is aware of large limitations of societal and political definitions of sustainable development; however, the following allows for a discussion on societal implications of MNEs in developing countries, given social justice as a foundational basis. 


\section{MNEs' Contributions to Sustainable Development}

Before presenting the results of the review, few words are spent to illustrate firms' contribution to sustainable development, with a focus on the role of MNEs. Hereby, firms' contribution to sustainable development will first be briefly discussed by looking at the historical and theoretical evolution of the concept and, second, at societal implications related to SDG 8.

It is widely acknowledged that sustainable development has three complementary dimensions: environmental, economic and social (Elkington and Rowlands 1999). Firms play a crucial role in all three and have, therefore, to be conceived as one of the key actors in achieving (or hindering) sustainable development. Sustainability thinking related to firms originated in the economic field in the 1930s, when the first articles about social responsibility of business appeared (Carroll 1999). The first theorization of the relationship between companies and society came in the 1950s by American economist Howard Bowen (1953), who argued that because firms are critical centers of power, they could influence the lives of citizens. In the 1970s, the concept of social responsibility, in addition to financial responsibility, started to be widely discussed. This new dimension of business attracted several critiques. The most renowned critique was by Milton Friedman, who argued that "the [only] social responsibility of business is to increase its profits" (Friedman 1970, p. 122). Nowadays, the main idea behind CSR is known as the "triple bottom line principle", implying that businesses should not only serve economic, but also social and environmental ends (Elkington and Rowlands 1999). The focus on profit does not disappear but is incorporated in the pressure of stakeholders such as consumers, civil society and governments that value such effort (McWilliams and Siegel 2001). In the last sixty years, literature on ethical responsibility in the corporate world has been growing substantially, contributing to different theoretical approaches theorizing the role of firms in sustainability. To mention a few: Corporate Social Responsibility (CSR), Stakeholder Theory, Corporate Sustainability and Green Economics (Chang et al. 2017). Despite growing consensus on the contribution of MNEs towards sustainable development, there is still great debate concerning the management of sustainability by MNEs, especially in the complex institutional setting of developing countries (Burritt et al. 2020).

As this chapter critically reviews tensions faced by MNEs in pursuing globally established sustainability guidelines, a discussion on how companies differ in interaction with societies through changing commitment is required. Garriga and Melé (2004) present a classification of four main theories: (1) instrumental theories, where the corporation is seen as an instrument for wealth creation, and its social 
activities are only a means to achieve economic results; (2) political theories, which are concerned with the power of corporations in society and a responsible use of this power in the political arena; (3) integrative theories, where the corporation is focused on the satisfaction of social demands; and (4) ethical theories, which are based on ethical responsibilities of corporations to society. Of the four, ethical theories are key in framing the contribution of companies to sustainable development from a justice perspective. An instructive example of these theories comes from Wettstein (2009). He argues that MNEs should pursue global justice because of their increased and autonomous role as agents of change and the weakened role of national states in the international governance set (ibid.). This is particularly true in developing countries, where MNEs are increasingly expected to fill in gaps of weak institutional settings (Crane and Matten 2005) and act as contributors to social development, given their financial and technological means (Crane and Matten 2005; Scherer and Palazzo 2008; Jamali 2010). MNEs can contribute to this social development in developing countries by promoting inclusive economic growth, which tackles unmet needs and increases overall well-being of the host-country (Gohou and Soumaré 2012; Kaplinsky 2013). This occurs when new job opportunities are created (Aaron 1999), as well as through the introduction of higher-quality goods into local markets, which can increase customers' well-being (Agénor 2004). Additionally, investment-based activities of MNEs can generate incentives for other firms and foreign business ventures to also invest in the region, resulting in additional employment opportunities (Kaplinsky 2013). Furthermore, MNEs can create incentives for local SMEs to expand by entering the local ecosystem of the MNE (ibid.). The latter is relevant for coupling economic growth with decent work. For instance, by entering the ecosystem of the MNE, the local business can get more competitive and indirectly more compliant to international standards, under the pressure of the partnership with the MNE (Aerni 2018).

These findings indicate how MNEs, if well addressed, demonstrate the potential to be drivers of positive change. Yet, despite positive externalities, MNEs have not always demonstrated behavior in favor of sustainable development. Indeed, this is a recent trend as the history of corporations is scarred by numerous cases of human rights violations and environmental disasters, especially in developing countries (Giuliani and Macchi 2014). The recent ethical turn on business by MNEs makes future systematic investigations more pressing.

From a societal and political perspective, the contribution of business towards sustainable development can also be analyzed in terms of the UN SDG Agenda. Indeed, businesses can influence all 17 Goals directly and indirectly. As opposed to 
their antecedents, the UN Millennium Goals, which mainly focused on governmental responsibility, the SDGs emphasize the role of all societal actors in achieving sustainable development and making a direct call for business engagement (SDG Compass 2015). The introduction of specific goals has both facilitated businesses by offering guidance in targeting specific domains of sustainable development and at the same time challenged them to comply with globally established goals in different contexts.

The activity of MNEs in developing countries is indirectly connected to all 17 goals; however, considering their primary role as economic actors, they can make a substantial contribution to Goal 8 by boosting economic growth while ensuring compliance with the highest international working standards.

While the SDGs make the responsibility of the private sector clear, it is disputable to what extent global actors such as MNEs are able to cover this role. For instance, the implementation of the SDGs in their business should not be confused with a communication exercise. On the contrary, the 17 goals should be strongly anchored in the core functions of the business and be made part of the business culture.

The paradigm shift advocated by Agenda 2030 presents many challenges to businesses, especially to transnational actors such as MNEs, which have to balance between the global expectations and complexities of the local context. This illustrates how corporate contributions to sustainability should escape simplistic categories and rather be prone to more complex contextualization. The first dimension of this contextualization will be addressed in the next section.

\section{Doing Business between Global Standards and Local Contexts}

To understand the relationship between global standards and the local context, it is necessary to first define what is meant by standards in general. According to the International Organization for Standardization, standards are: "documents established by consensus [ ... ] that provide, for common and repeated use, rules, guidelines or characteristics for activities or their results, aimed at the achievement of the optimum degree of order in a given context" (International Organization for Standardization 2018, p. 2). In the following chapter, the notion of standards generically refers to international guidelines related to compliance with sustainable development issues levied on MNEs working across cross-cultural contexts. An exhaustive exploration of international standards is beyond the scope of this chapter as it would preliminarily require a definition of one specific sector where the standards are established. The following paragraph rather aims at presenting 
relevant debates from the business ethics literature on how companies are facing this tension.

Literature that investigates the relationship between global standards and the local context presents differentiated disciplinary backgrounds, given the widespread perspective from which it can be examined. One field that mostly contributed to describing companies' challenges associated with compliance with global standards in local contexts is international business ethics (De George 1993; Donaldson and Dunfee 1994; Kolk and Tulder 2004). The most dominant research interest in this field is associated with the relationship between "culture and ethics" (Javalgi and Toya 2018). Indeed, ethical standards result as the expression of a specific ethical perception, while the peculiarities of local context and the communities that are part of it can be understood through cultural determinants (Soares et al. 2007).

Given the relevance of literature in this domain, this section presents ethical considerations guiding business activities across cross-cultural contexts. The major part treats a classical controversy in international business ethics, notably the one between cultural relativism and ethical imperialism. Hereby, conceptual notions are exemplified along empirical evidence from more recent studies. In the final part, other perspectives are presented that are equally located in the international business ethics literature but look at the relationship between global standards and local context from a different angle.

The first overarching debate that engaged with the tension between global ethical standards and local context is the one between cultural relativism and ethical imperialism in business ethics. Cultural relativism emerged in the anthropological research by Franz Boas in the first decades of the 19th century (Dall and Franz 1887). The essence of cultural relativism can be synthesized by the creed "When in Rome, do as Romans do" (Donaldson 1996). This means that, within the infinite cultural diversity, all cultural practices are considered equally valid. There are no absolute criteria for judging one practice as better than another (Katherine 1988) and the standards that people use to judge behavior are relative to the culture in which they are raised (Herskovits 1973). Thus, there are no international rights and wrongs in cultural practices. This implies that this conception of cultural practices questions the validity of human rights theory, which aims to create absolutes for judging the actions of all cultures (Katherine 1988).

In contrast to cultural relativism is ethical imperialism. This is based on absolutistic claims of truth expressed with unique sets of categories (Kolb 2008). In business ethics this describes a situation where a specific ethical code is imposed from a company to another with different standards (ibid.). 
Kolk and Tulder (2004) offer an empirical exemplification of these two different logics by examining child labor codes in MNEs. Because of different cultural perceptions of children in society, host-countries and the Western home-country may differ on the adopted standards (ibid.). Their research analyzes how fifty leading MNEs address dilemmas related to conflicting norms and expectations from working in foreign countries, focusing on corporate codes of ethics. They found that, in the case of child labor regulations, a multidomestic approach (relativist approach) is more prevalent than a global strategy (universalist approach). ${ }^{7}$ In other words, the examined MNEs tend to adapt to host-country laws rather than adopting Western home-country laws, where the latter are usually stricter (ibid.).

However, when ethical imperialism and cultural relativism are translated into practice, they both display inadequacies. A radical cultural relativistic perspective can result in moral blindness when it is not making an exception of fundamental standards across cultures. Advocates of human rights theory argue that the wide tolerance of cultural relativism can pose threats to the legitimacy of the existing international human rights system (Katherine 1988). Managers could, for instance, use cultural relativism as an excuse to tolerate unethical behaviors to ensure business opportunities (Donaldson 1996). On the other hand, ethical imperialism is constrained by its absolutistic foundations (ibid.). Every country is based on a different foundation of ethical behavior, which leads to a variety of ethical standards among countries. The belief in a universal ethical standard of behavior is inconsistent as we observe that ethical practice is continuously influenced by context (Donaldson and Dunfee 1994). Applying universal standards without taking into consideration the conditions in the local context may lead to inadequate compliance. Such ineffective attempts have been investigated in a study on working conditions in Chinese clothing industries (Ngai 2005). Many Chinese manufacturing enterprises working for Western multinationals in the fashion industry have had to enhance the factories' regulations on workers' conditions due to anti-sweatshop movements. The study showed that, despite the improvement in terms of reduced working hours, the Chinese employees still wanted to work overtime as the basic salary would have been too low to support their basic needs (Ngai 2005).

7 Both multidomestic and global MNEs are characterized for their operation in different countries; however, they differ in their strategic approach. Multidomestic MNEs adapt their business model depending on the country in which they are active, based on market opportunities and cultural values, while global MNEs have a centralized approach and reproduce a similar business strategy in all the countries where they operate. For a further differentiation and empirical support of these categories see Harzing (2000). 
A third rationale is introduced by Donaldson and Dunfee (1994) to overcome limitations of cultural relativism and ethical imperialism: "moral free space". The moral free space is conceptualized as an acknowledgement to context-specific conditions coexisting with some form of human core values (hypernorms) (ibid.). ${ }^{8}$

Despite the dominance of the culture-ethic relationship in informing international business ethics, considerations on the relationship between international standards and local context have gained importance in other perspectives. Institutional approaches, for instance, have explained the relationship between international standards and local context in terms of internal and external pressures to conform to legitimacy (DiMaggio and Powell 1983). Yang and Rivers (2009) show that subsidiaries of MNEs will likely adapt to local practices to legitimize themselves if they operate in developing countries with diverse institutional structures and stakeholder bases. Other studies in the field have analyzed how the adoption of global standards redefines local practices (Mennicken 2008). By exploring the application of global accounting standards in an emerging economy, Albu et al. (2014) illustrate how the interplay of local actors and their search for legitimacy can influence organizational adaptations to the local context.

To conclude, it is worth mentioning that the multidimensional nature of the relationship was of great inspiration also for governance scholars (Fung 2003). A study of governance arrangements of global agri-food markets in the Kenyan horticulture industry shed light on the disputed nature of the implementation of global standards in local contexts characterized by different standards of quality and production processes in the market (Ouma 2010). Other studies on global governance investigated the double-sided nature of international standards that lead to the exclusion of emerging economies to profitable markets due to non-compliance with the latter (Nadvi 2008).

\section{Tensions in Corporate Social Responsibility}

The ambivalent nature of CSR raises challenges to MNEs operating in cross-cultural contexts. Today's MNEs are not limited to external pressure from compliance with global and local ethical standards but are facing new challenges in their organization dimension as well. In contrast with past companies, current MNEs are increasingly compelled by their stakeholder base to increase their CSR dimension.

8 Examples of hypernorms are human dignity, respect for basic rights and good citizenship. The concept of hypernorms is the basis of the Integrative Social Contract Theory developed by Donaldson and Dunfee (1994). 
For instance, since 2018, the European Union requires all companies with more than 500 employees to disclose information on the way they operate and manage social and environmental challenges. Information to be disclosed must include clarifications on the way companies address environmental protection, social responsibility and treatment of employees, respect for human rights, anti-corruption and bribery, and diversity in company boards (European Parliament 2014). ${ }^{9}$ CSR practices advanced by companies do not represent the ultimate solutions to these challenges but present themselves as inherent tensions originating from the complex nature of sustainable development. In other words, modern MNEs must comply with international standards in cross-cultural contexts while ensuring their CSR guidelines and coping with their own controversies. The question, therefore, is: Do CSR practices fit in the global-local tension? Are they enforcing the tension or, alternatively, creating synergies? ${ }^{10}$

Tensions occurring at the corporate level in complying with sustainability dimensions have been addressed by organization scholars, focusing on trade-offs in CSR (Hahn et al. 2010). ${ }^{11}$ This concept is relevant to the overall topic for two reasons. First, it allows for clearer identification of the somehow blurring concept of "tensions", with the more concrete understanding of "trade-offs". Trade-offs in CSR are defined as "those situations in which corporate contributions to sustainable development can only be achieved if one accepts a compromise between at least two sustainability aspects that are in conflict [with] each other" (Hahn et al. 2010, p. 220). This definition does not imply that circumstances of trade-offs automatically result in a lower contribution to sustainable development compared with win-win situations (ibid.). Second, the concept of trade-offs is strongly linked to the concept of synergies (Haffar and Searcy 2017). Tension between two or more CSR criteria can result in either sustainability trade-offs or sustainability synergy (Epstein et al. 2014). Thus, from the identification of trade-offs, it could be possible to retrieve synergies.

9 Directive 2014/95/EU of the European Parliament and of the Council.

10 This question is relevant when CSR trade-offs are linked with ethical tensions on the global-local level. However, an exhaustive answer to this question would require an empirical exploration of these different dimensions and is left to future in-depth analyses.

11 Please note that Hahn et al. define "trade-offs" in respect to corporate sustainability (2010), whereas the following review adopts the notion of corporate social responsibility (CSR). Since the CSR definition provided by the European Commission encompasses the three dimensions of sustainable development, it is argued that the definition of trade-offs by Hahn et. can be equally applied to trade-offs in CSR. 
Hereby, two debates on trade-offs happening in CSR are presented: the first is overarching and foresees trade-offs in the notion of CSR, and the second is context-specific and analyzes CSR tensions in cross-cultural contexts.

Literature on CSR has traditionally been dominated by a "win-win perspective" on the three principles of economics, society and environment (Hahn et al. 2010). However, given the complex and multi-faceted nature of sustainable development and the change involved, a discussion on trade-offs and tensions is equally urgent (ibid.). Additionally, as presented in Section 3, the concept of CSR has its roots in Western democratic countries and relies on typical rights and obligations which characterize these societies. However, in many developing countries it might be difficult to ensure the same conditions, and this could result in inadequate or lacking applications of CSR (Prieto-Carrón et al. 2006).

Based on these considerations, scholars have started to challenge the win-win paradigm that CSR is achieved only at the intersection of the three principles of economic, environmental and social aspects of sustainable development and describe trade-offs in CSR as situations where these principles cannot be achieved simultaneously (Hahn et al. 2010; Prieto-Carrón et al. 2006; Haffar and Searcy 2017). The analysis of trade-offs does not attempt to resolve the conflict between different disciplines but tries to "clarify the competing considerations, probe what gives them weight and explore their relationship" (Margolis and Walsh 2003, p. 284). This perspective allows for a more inclusive notion of CSR and for enriching contributions to sustainable development (Hahn et al. 2010).

In this sense, a useful contribution is represented by methodological frameworks aiming at detecting trade-offs in CSR at different levels. Hahn et al. (2010) show that trade-offs in CSR can occur at different levels (individual, organizational, industrial and societal) and dimensions (outcome, temporal and process). Haffar and Searcy (2017) analyze the link between sustainability trade-offs and sustainability synergies, developing a framework to understand when tensions can transform into opportunities. The framework is built on three tension areas (private value-shared value, scope-depth, measurement-management) and corresponding trade-offs categories. One of these categories involves the strategic role of stakeholders in influencing the decision-making process of a company along its supply chain. This is of key importance because perceptions of the conflicts of CSR can considerably diverge between stakeholder groups (Angus-Leppan et al. 2010).

Other scholars (Rost and Ehrmann 2017) analyzed distortions in the notion of CSR by investigating trade-offs between corporate social performance (CSP) and corporate financial performance (CFP) in reporting biases in empirical management 
literature. In their study, they showed that published evidence in win-win CSR research tends to overestimate efficiency. The research field expects to find a positive association between CSP and CFP, while the authors demonstrate strong tentative evidence for a positive reporting bias in the CSP-CFP literature but only weak tentative evidence for CSP efficiency (Rost and Ehrmann 2017). The trend of the reporting bias may be influenced by collective cognitive structures within a research discipline (e.g., authors not writing on unfavorable findings, higher rejection rates of studies documenting conflicting evidence, etc.). The authors point out that the implications of such distortions are severe when results are being used by academics and practitioners to justify research questions and results or support decision making in the business context. The consequences of this reporting bias "may result in inappropriate decisions by policymakers, managers, or scholars, and could thereby harm employees and other stakeholders, and lead to wasted resources and misdirected future research" (Rost and Ehrmann 2017, p. 34).

The second stream of research has engaged with trade-offs of CSR occurring in cross-cultural contexts. In this field, scholars focus on shortcomings of the traditional Western understanding of CSR in developing countries and emphasize the need to avoid a "one size fits all approach" and opting for a contextualized understanding of CSR in middle and low-income countries (Prieto-Carrón et al. 2006; Utting and Marques 2010; Khojastehpour and Jamali 2020). Utting and Marques (2010) argue that the mainstream Western CSR debate has tended to ignore important developmental issues related to corporate power, economic liberalization, unsustainable investment and consumption patterns. Additionally, Prieto-Carrón et al. (2006) point out that a one-sided view of CSR ignores more complex issues about the actual impacts of CSR initiatives such as the roles of power, class and gender which characterize those interventions. Empirical evidence from developing countries suggests that the standard management-oriented discourse on CSR may result in limited contributions (Prieto-Carrón et al. 2006), specifically concerning the significance that CSR initiatives may assume in these countries. For instance, many companies in developing countries make donations for philanthropic purposes (Kumar et al. 2001). However, according to some scholars (von Schnurbein et al. 2016), this is not considered CSR as it is not directly related to the core business strategies of companies. A concrete example for that comes from India where in 2013 the government brought into law a mandate on firms' CSR spending (Ministry of Corporate Affairs MCA). Although the new law improved general awareness of CSR issues, this further enforced the traditional philanthropic dimension of CSR in India (Yesudhas 2017). 
An attempt to overcome the hegemony of Western notions of CSR may be represented by the distinction between global and local CSR. The latter focuses on different perspectives on whether MNEs should develop centrally coordinated global CSR strategies, or whether they should stimulate decentralized, local CSR strategies (Muller 2006). Husted and Allen (2006) suggest that the key difference between global and local CSR is the community that demands it. Local CSR deals with the firm's obligations based on the standards of the local community, whereas global CSR deals with the firm's obligations based on global standards to which all societies can be held. While centralization can be more efficient, it can lead to a lack of ownership and reduced legitimacy at the local level. At the same time, decentralized strategies, while locally responsive, may also be fragmented and context dependent (Husted and Allen 2006). When the local context is a developing country with lower CSR standards and less public pressure, the risk is that multinationals target the lower rather than higher standards that may be expected from them in their home countries (Muller 2006). Definitive evaluations on which approach is the most effective are difficult to attain, as the outcome of global or local CSR approaches is strictly dependent on the host-country where the company is operating. For instance, in his study on CSR in Mexican subsidiaries of European MNEs in the automotive industry, Muller finds empirical support that in a "lower CSR context", decentralized decision-making is associated with higher local CSR performance (2006).

\section{Discussing MNEs' Corporate Social Responsibility in Global Standards and Local Complexities}

In the following section, the abovementioned knowledge on tensions happening in the triangular relationship between global ethical standards, the local context and CSR guidelines faced by MNEs operating in developing countries is brought together and developed further.

Underlying justice implications frame the activity of MNEs in developing countries as a relevant topic for sustainability research. Due to societal pressure and increased agency in the governance set, multinationals are required to assume an active role in promoting economic growth, while ensuring compliance with the highest sustainability standards. However, the application of international ethical guidelines is not straightforward and needs to be adapted to the condition of the local context. Among different framing forces of this environment, culture has a major impact on human behavior and individuals' ethical perceptions (Soares et al. 2007). Thus, culture can be seen as an influencing factor for ethical standards in businesses across different countries. In this sense, the debate between cultural relativism 
and ethical imperialism is exemplificative of inadequacies of one-way solutions. Rather, when doing business across different cultures, managers should try to balance compliance with universalistic ethical standards with relativistic adaptations to the local context.

Different approaches have contributed to explain when MNEs are faced with local-global tensions: (1) ethical theories, which are among the most prominent in the field, describe tensions in business when global and local ethical standards, influenced by different cultures, come together; (2) institutionalist theories envisage tensions when MNEs are subject to different (international and local) pressures for legitimacy; (3) governance theories detect tensions which arise from the multidimensional and multi-spatial nature of MNEs.

Additionally, an MNE that is working in a developing country not only faces challenges from the management of global-local requests but also has to comply with its own CSR dimension, which presents itself as inherent tensions. These tensions can be better understood with the notion of trade-offs and are distinguished as (1) internal trade-offs, which are inherent in the nature of CSR and question the simultaneous contribution to sustainable development of all three economic, social and environmental principles, and (2) external trade-offs, which take place when Western conceptualizations of CSR are exported and contextualized among cross-cultural contexts.

Given their global reach, MNEs are facing multiple pressures to contribute to sustainability targets. The exposure to these conflicting forces may result in tensions between the three levels (global-local-organizational).

At first glance, the boundaries of tensions between global-local and the organization's level may be blurred and sometimes overlapping. CSR initiatives, for instance, could represent the incorporation of international standards at the business level. However, the rationale that guides the adoption of certain rules at a company level may be very different from that of an international organization. The influence of the three different levels (global, local, organizational) and motivations that guide them are key determinants to understand and try to manage tensions occurring between and within the three levels. Each level is characterized by its context and specific values. Tensions may arise between the levels when conflicting values are brought together.

These findings suggest that in order to successfully implement the global standards in cross-cultural contexts, MNEs are required to embed these standards in the local economic ecosystem of developing countries. They should, in other words, work as facilitators between the global ethical standards and the local dimension. 
This would, however, require a coherent CSR agenda that is firmly anchored to the core business of the company.

In view of these findings and recurring themes between the two strains of literature, a list of criteria that should guide the identification of relevant theoretical approaches is developed. Such criteria could help scholars to identify suitable theories aiming at detecting tensions between global standards and local context and at the CSR organizational level in empirical explorations and consequently increase scientific support on multilevel tensions faced by MNEs in developing countries. In this sense, a fertile theory that analyzes tensions faced by an MNE in a developing country on the three levels should: (1) represent prominent theories in international ethical business, (2) have been used in previous studies to understand CSR practices of businesses, (3) take into consideration the societal environment in which a company is operating, (4) have been used to address the activity of MNEs in cross-cultural contexts and finally, and (5) have sound scientific bases to examine the values of a corporation and the different environments where it is operating.

Moreover, throughout this chapter, some research gaps related to tensions faced by MNEs operating in developing countries were identified. Based on the review at hand, a recapitulating list of knowledge gaps is presented. ${ }^{12}$

From the literature consulted, it is derived that there is an overall lack of critical investigation on the concept of CSR in three domains: Firstly, acknowledgment and assessment of trade-offs and conflicts between the economic, environmental and social principles inherent in the nature of sustainable development (Hahn et al. 2010); secondly, the dominance of the mainstream Western notion of CSR and little systemic investigations on the adaptations/variations in different cross-cultural contexts, especially in developing countries (Prieto-Carrón et al. 2006; Khojastehpour and Jamali 2020). In this regard, there is especially little information on how local and global socio-political-economic factors influence CSR meaning (Mitra 2012). Additionally, evidence on CSR activities of MNEs in developing countries are "scant, mixed, and fragmented" (Jamali 2010, p. 184). A third domain that requires further investigation is that of reporting methodological biases on the relation of CSP and CFP (Rost and Ehrmann 2017). Additionally, few studies examine cultural adaptations of Western subsidiary MNEs in developing countries (Márquez et al. 2016) and how

12 The following list of knowledge gaps is uniquely based on the author's current knowledge and the consultation of literature. If some gaps are indeed filled, this may be due to oversight. 
MNEs are dealing with tensions occurring from multidimensional levels, namely, global standards, local contexts and companies' guidelines.

Based on the following gaps, it is suggested that scholars engage in a discussion on trade-offs in CSR given the complex and multifaceted nature of sustainable development and ethical questions arising from the activity of MNEs in developing countries by critically investigating variances of CSR practices in developing countries. Additionally, questions of cultural fit of MNEs in developing countries should be investigated as the successful adaptation to local context is a driver for FDI.

Finally, and most importantly, it is recommended that scholars investigate naturally occurring tensions stemming from the multidimensional dimension in which MNEs are embedded, namely, global, local and organizational. As this review sets the stage for exploring multilevel sustainability tensions faced by MNEs, future research can build on these findings to develop appropriate strategies to deal with these tensions. Such knowledge would not only contribute to the academic debate but also be relevant for the societal and political agenda towards sustainable development. In terms of SDG 8, a comprehensive understanding and identification of multilevel tensions faced by MNEs represents a prerequisite for the achievement of "inclusive and sustainable economic growth".

\section{Concluding Remarks}

This chapter aimed to explore literature on tensions faced by MNEs in developing countries when confronted with global standards, local context and CSR guidelines. Given the few studies addressing the three levels simultaneously, relevant knowledge was gathered by examining two separate debates in international business ethics literature, namely, the relationship between "business ethics and culture" and "trade-offs in CSR".

The review of distinguished debates gives an overarching perspective on the multidimensional tensions faced by MNEs in developing countries. Additionally, based on these findings, criteria for the selection of suitable theoretical frameworks are developed, which could guide scholars to identify relevant theories to analyze tensions faced by real-world MNEs operating in developing countries.

The review of relevant literature emphasizes the importance of wider consideration of the context where the company is embedded. In this sense, the perspective on MNEs in developing countries allows one to better understand framing conditions in complex institutional environments and ultimately prevent other "Rana Plazas" from happening. 
Moreover, in an era where the reputational character of MNEs is increasingly under the spotlight, identifying issues that could raise tensions and trade-offs on the three levels becomes fundamental to design as well as putting in place strategies to respond adequately to external and internal threads.

The author is aware that some debates have been presented without entering into an extended discussion. Ethical tensions faced by MNEs have attracted infinite numbers of contributions, and exhaustive exploration of all of them is beyond the scope of this chapter.

Despite some limitations, the author hopes that this chapter may represent a starting point to further discuss tensions happening at the different levels of operation of MNEs in developing countries.

Author Contributions: The author confirms sole responsibility for the following: work conception and design, review of articles, analysis and interpretation of the articles, and manuscript preparation.

Funding: This research received no external funding.

Acknowledgments: I thank the three anonymous reviewers whose valuable comments and suggestions helped improve and clarify this manuscript.

Conflicts of Interest: The author declares no conflict of interest.

\section{References}

Aaron, Carl. 1999. The Contribution of FDI to Poverty Alleviation. In Report from the Foreign Investment Advisory Service Presented at the Foreign Investment Advisory Service Conference in Singapore July 1998 (n.d.). Washington D.C.: World Bank.

Aerni, Philipp. 2018. Global Business in Local Culture: The Impact of Embedded Multinational Enterprises. Cham: Springer Nature.

Agénor, Pierre-Richard. 2004. Does globalization hurt the poor? International Economics and Economic Policy 1, pp. 21-51. [CrossRef]

Albu, Cătălin Nicolae, Nadia Albu, and David Alexander. 2014. When global accounting standards meet the local context-Insights from an emerging economy. Critical Perspectives on Accounting 25, pp. 489-510. [CrossRef]

Angus-Leppan, Tamsin, Suzanne Benn, and Louise Young. 2010. A sensemaking approach to trade-offs and synergies between human and ecological elements of corporate sustainability. Business Strategy and the Environment 19, pp. 230-44. [CrossRef]

Barua, Uttama, and Mehedi Ahmed Ansary. 2017. Workplace safety in Bangladesh ready-made garment sector: 3 years after the Rana Plaza collapse. International Journal of Occupational Safety and Ergonomics 23, pp. 578-83. [CrossRef] [PubMed] 
BBC. 2013. Bangladesh Factory Collapse Toll Passes 1000. London: BBC, May 10, Available online: https://www.bbc.com/news/world-asia-22476774 (accessed on 10 April 2020).

Bowen, Howard R. 1953. Social Responsibilities of the Businessman. New York: Harper.

Katherine, Brennan. 1988. The Influence of Cultural Relativism on International Human Rights Law: Female Circumcision as a Case Study. Law and Inequality: A Journal of Theory and Practice 7, pp. 367-98.

Burritt, Roger Leonard, Katherine Leanne Christ, Hussain Gulzar Rammal, and Stefan Schaltegger. 2020. Multinational Enterprise Strategies for Addressing Sustainability: The Need for Consolidation. Journal of Business Ethics 164, pp. 389-410. [CrossRef]

Carroll, Archie B. 1999. Corporate social responsibility evolution of a definitional construct. Bus Society 38, pp. 268-95. [CrossRef]

Chang, Rui-Dong, Jian Zuo, Zhen-Yu Zhao, George Zillante, Xiao-Long Gan, and Veronica Soebarto. 2017. Evolving theories of sustainability and firms: History, future directions and implications for renewable energy research. Renewable and Sustainable Energy Reviews 72, pp. 48-56. [CrossRef]

Chowdhury, Rashedur. 2017. Rana Plaza Fieldwork and Academic Anxiety: Some Reflections. Journal of Management Studies 54, pp. 1111-17. [CrossRef]

Crane, Andrew, and Dirk Matten. 2005. Corporate Citizenship: Missing the Point or Missing the Boat? A Reply to van Oosterhout. Academy of Management Review 30, pp. 681-84. [CrossRef]

Dall, William Healey, and Boas Franz. 1887. Museums of ethnology and their classification. Science 9, pp. 587-89. [CrossRef] [PubMed]

De George, Richard T. 1993. Competing with Integrity in International Business. New York: Oxford University Press, vol. xii, p. 233.

Donaldson, Thomas. 1996. Values in Tension: Ethics Away from Home. Harvard Business Review. September-October 1996 Issue. Available online: https://hbr.org/1996/09/valuesin-tension-ethics-away-from-home (accessed on 18 March 2020).

Donaldson, Thomas, and Thomas W. Dunfee. 1994. Toward a unified conception of business ethics: Integrative Social Contracts Theory. Academy of Management Review 19, pp. 252-84. [CrossRef]

Dunning, John H., and Sarianna M. Lundan. 2008. Multinational Enterprises and the Global Economy. Cheltenham: Edward Elgar Publishing.

Elkington, John, and Ian H. Rowlands. 1999. Cannibals with forks: The triple bottom line of 21st century business. Alternatives Journal 25, p. 42.

Epstein, Marc J., Adriana Rejc Buhovac, and Kristi Yuthas. 2014. Managing social, environmental and financial performance simultaneously. Long Range Planning 48, pp. 35-45. [CrossRef] 
European Commission. 2011. European Union: European Commission, Communication from the Commission to the European Parliament, the Council, the European Economic and Social Committee and the Committee of the Regions. A Renewed EU Strategy 2011-2014 for Corporate Social Responsibility. 25 October 2011, COM(2011) 681 Final. Available online: https://eur-lex.europa.eu/legal-content/en/TXT/?uri=CELEX: 52011DC0681 (accessed on 5 May 2020).

European Parliament. 2014. Directive 2014/95/EU of the European Parliament and of the Council of 22 October 2014 Amending Directive 2013/34/EU as Regards Disclosure of Non-Financial and Diversity Information by Certain Large Undertakings and Groups Text with EEA Relevance. Available online: https://eur-lex.europa.eu/eli/dir/2014/95/oj (accessed on 19 March 2020).

Friedman, Milton. 1970. The Social Responsibility of Business is to Increase Its Profits. The New York Times, September 13, p. 122.

Fung, Archon. 2003. Deliberative Democracy and International Labor Standards. Governance 16, pp. 51-71. [CrossRef]

Garriga, Elisabet, and Domènec Melé. 2004. Corporate Social Responsibility Theories: Mapping the Territory. Journal of Business Ethics 53, pp. 51-71. [CrossRef]

Giuliani, Elisa, and Chiara Macchi. 2014. Multinational corporations' economic and human rights impacts on developing countries: a review and research agenda. Cambridge journal of economics 38, pp. 479-517. [CrossRef]

Gohou, Gaston, and Issouf Soumaré. 2012. Does foreign direct investment reduce poverty in Africa and are there regional differences? World Development 40, pp. 75-95. [CrossRef]

Haffar, Merriam, and Cory Searcy. 2017. Classification of Trade-offs Encountered in the Practice of Corporate Sustainability. Journal of Business Ethics 140, pp. 495-522. [CrossRef]

Hahn, Tobias, Frank Figge, Jonatan Pinkse, and Lutz Preuss. 2010. Trade-offs in corporate sustainability: You can't have your cake and eat it. Business Strategy and the Environment 19, pp. 217-29. [CrossRef]

Harzing, Anne-Wil. 2000. An Empirical Analysis and Extension of the Bartlett and Ghoshal Typology of Multinational Companies. Journal of International Business Studies 31, pp. 101-20. [CrossRef]

Herskovits, Melville Jean. 1973. Cultural Relativism: Perspectives in Cultural Pluralism, Vintage 1st Vintage Books ed. New York: Random House, pp. xxvi-293.

Husted, Bryan W., and David B Allen. 2006. Corporate social responsibility in the multinational enterprise: Strategic and institutional approaches. Journal of International Business Studies 37, pp. 838-49. [CrossRef]

International Organization for Standardization, International Electrotechnical Commission (ISO/IEC). 2018. Directives, Part 2: Principles and Rules for the Structure and Drafting of ISO and IEC Documents. Geneva: International Organization for Standardization. 
Jamali, Dima. 2010. The CSR of MNC Subsidiaries in Developing Countries: Global, Local, Substantive or Diluted? Journal of Business Ethics 93, pp. 181-200. [CrossRef]

Javalgi, Rajshekhar G., and Russell M. La Toya. 2018. International Marketing Ethics: A Literature Review and Research Agenda. Journal of Business Ethics 148, pp. 703-20. [CrossRef]

Kaplinsky, Raphael. 2013. What contribution can China make to inclusive growth in sub-Saharan Africa? Development and Change 44, pp. 1295-1316. [CrossRef]

Khojastehpour, Morteza, and Dima Jamali. 2020. Institutional Complexity of Host Country and Corporate Social Responsibility: Developing vs Developed Countries. Social Responsibility Journal. ahead-of-print. [CrossRef]

Kolb, Robert. W. 2008. Encyclopedia of Business Ethics and Society. Thousand Oaks: Sage Publications.

Kolk, Ans, and Rob Van Tulder. 2004. Ethics in international business: Multinational approaches to child labor. Journal of World Business 39, pp. 49-60. [CrossRef]

Kumar, Ritu, David F. Murphy, and Viraal Balsari. 2001. Altered Images: The 2001 State of Corporate Responsibility in India Poll. Understanding and Encouraging Corporate Responsibility in South Asia: Update One. New Delhi: Tata Energy Research Institute.

Margolis, Joshua D., and James P. Walsh. 2003. Misery Loves Companies: Rethinking Social Initiatives by Business. Administrative Science Quarterly 48, pp. 268-305. [CrossRef]

Márquez, Felix Barahona, Fariza Achcaoucaou, and Paloma Miravitlles Matamoros. 2016. Mitigating the Isomorphic Conflicts Faced by EMNEs in Southern Europe: The Case of Chinese Subsidiaries in Spain. Journal of Evolutionary Studies in Business 1, pp. 201-34.

McWilliams, Abagail, and Donald Siegel. 2001. Profit-Maximizing Corporate Social Responsibility. The Academy of Management Review 26, pp. 504-5. [CrossRef]

Mennicken, Andrea. 2008. Connecting worlds: The translation of international auditing standards into post-Soviet audit practice. Accounting, Organizations and Society 33, pp. 384-414. [CrossRef]

Ministry of Corporate Affairs (MCA). 2013. The companies act, 2013. Available online: www.mca.gov.in/Ministry/pdf/CompaniesAct2013.pdf (accessed on 12 December 2020).

Mitra, Rahul. 2012. "My Country's Future": A Culture-Centered Interrogation of Corporate Social Responsibility in India. Journal of Business Ethics 106, pp. 131-47. [CrossRef]

Muller, Alan. 2006. Global Versus Local CSR Strategies. European Management Journal 24, pp. 189-98. [CrossRef]

Nadvi, Khalid. 2008. Global standards, global governance and the organization of global value chains. Journal of Economic Geography 8, pp. 323-43. [CrossRef]

Ngai, Pun. 2005. Global Production, Company Codes of Conduct, and Labor Conditions in China: A Case Study of Two Factories. The China Journal 54, pp. 101-13. [CrossRef]

Nilsson, Måns, Dave Griggs, and Martin Visbeck. 2016. Policy: Map the interactions between Sustainable Development Goals. Nature 534, pp. 320-22. [CrossRef] [PubMed] 
Organisation for Economic Co-operation and Development (OECD). 2018. Due Diligence Guidance for Responsible Supply Chains in the Garment and Footwear Sector. Paris: OECD Publishing.

Ouma, Stefan. 2010. Global Standards, Local Realities: Private Agrifood Governance and the Restructuring of the Kenyan Horticulture Industry. Economic Geography 86, pp. 197-222. [CrossRef]

Prieto-Carrón, Marina, Peter Lund-Thomsen, Anita Chan, Ana Muro, and Chandra Bhushan. 2006. Critical perspectives on CSR and development: What we know, what we don't know, and what we need to know. International Affairs 82, pp. 977-87.

Rost, Katja, and Thomas Ehrmann. 2017. Reporting Biases in Empirical Management Research: The Example of Win-Win Corporate Social Responsibility. Business and Society 56, pp. 840-888. [CrossRef]

Scherer, Andreas Georg, and Guido Palazzo. 2008. Globalization and Corporate Social Responsibility. In The Oxford Handbook of Corporate Social Responsibility. Edited by Andrew Crane, Abgail McWilliams, Dirk Matten, Jeremy Moon and Donald S. Siegel. Oxford: Oxford University Press, pp. 413-31.

Soares, Ana Maria, Minoo Farhangmehr, and Aviv Shoham. 2007. Hofstede's dimensions of culture in international marketing studies. Journal of Business Research 60, pp. 277-84. [CrossRef]

United Nations General Assembly. 2015. Transforming our world: the 2030 Agenda for Sustainable Development. A/RES/70/1. Available online: https://www.refworld.org/ docid/57b6e3e44.html (accessed on 12 January 2021).

Utting, Peter, and José Carlos Marques. 2010. Introduction: The Intellectual Crisis of CSR. In Corporate Social Responsibility and Regulatory Governance. Edited by Utting Peter and José Carlos Marques. International Political Economy Series. London: Palgrave Macmillan, pp. 1-25.

von Schnurbein, Georg, Peter Seele, and Irina Lock. 2016. Exclusive corporate philanthropy: Rethinking the nexus of CSR and corporate philanthropy. Social Responsibility Journal 12, pp. 280-94. [CrossRef]

World Commission on Environment and Development (WCED). 1987. Our Common Future:

The Report of the World Commission on Environment and Development. Oxford: Oxford University Press.

Wettstein, Florian. 2009. Multinational Corporations and Global Justice: Human Rights. Obligations of a Quasi-Governmental Institution. Stanford: Stanford University Press.

World Bank. 2019. World Development Report 2020: Trading for Development in the Age of Global Value Chains. Washington: District of Columbia.

Yang, Xiaohua, and Cheryl Rivers. 2009. Antecedents of CSR practices in MNCs' subsidiaries: A stakeholder and institutional perspective. Journal of Business Ethics 86, pp. 155-69. [CrossRef] 
Yesudhas, Ronald. 2017. Paper presented at the National Conference on Child Protection and Education organized by the College of Social Work, Nirmala Niketan on 29th and 30th March 2017. Mumbai.

(C) 2021 by the author. Licensee MDPI, Basel, Switzerland. This article is an open access article distributed under the terms and conditions of the Creative Commons Attribution (CC BY) license (http://creativecommons.org/licenses/by/4.0/). 


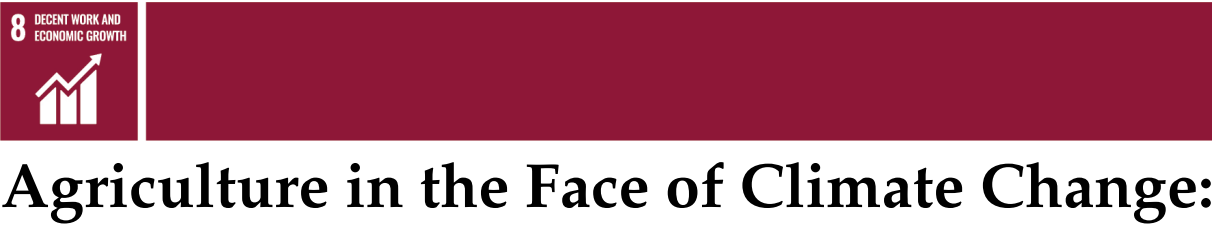

\title{
Agriculture in the Face of Climate Change: Sustained and Inclusive Economic Growth as a Prerequisite for Sustainable Development
}

\author{
Romano De Vivo, Ettore Capri, Henri Rueff, Antonio Gaudioso, \\ Alexandru Marchis and Gianpiero Menza
}

\section{Introduction}

Climate change and weather extremes are already impacting millions of people, devastating crops, eroding coastlines, and threatening freshwater reserves. A continued build-up of greenhouse gas (GHG) pollution is expected to lead to warming, more acidic oceans and a continued rise in the sea level, changed weather patterns, and an even more significant threat to supplies of food, water, and fish (IPCC 2014). The food and agriculture sector is particularly vulnerable and will be hit in multiple ways (FAO 2016a).

According to the Intergovernmental Panel on Climate Change (IPCC) Fifth Assessment Report, the effects of climate change on crop and food production are already visible, reducing yields, mainly for wheat, maize, and rice, ${ }^{1}$ in some parts of the world (IPCC 2014). A further rise in temperatures will likely exacerbate such effects. Food production will be impacted by climate change itself, as well as related issues such as water availability, pests, and disease. While there may be some positive effects, the most likely results are very worrying and are expected to have environmental, social, and economic dimensions (IPCC 2019).

This is particularly true in emerging economies, where the food and agricultural sectors (agri-food) make a significant contribution to economic performance: smallholder farmers and the rural poor in such areas appear to suffer even more due to the limited resilience and diversity of production (FAO 2015a). Climate change is expected to reduce soil resilience and increase the vulnerability of products and producers, and destabilize markets with higher price volatility (Chatzopoulos et al.

1 In cereal production, "there is evidence that climate change has already negatively affected wheat and maize yields in many regions and at the global level. The IPCC warns that decreases in crop yields of 10 to 25 per cent and more may be widespread by 2050". Furthermore, "the increased frequency of warmer nights in most regions is ... impacting rice yields and quality" (FAO 2017a). 
2020). If producers are not flexible enough to shift and adapt quickly to changing crop suitability, we can, for instance, expect increased migratory pressure, with people moving away from farming and into cities and even across borders (IPCC 2014). That is, if not dealt with properly—and quickly—climate change will hinder the achievement of vital goals for human development: it threatens to undermine and maybe even reverse recent progress in the fight against poverty, hunger, and malnutrition (UN 2019a).

Still, we can only expect effective measures if all stakeholders-individual farmers as well as governments, research institutions, advisors, providers of technical solutions, and the financial sector-increase and coordinate their efforts (McKinsey and Company 2015).

Decisive, ambitious measures could help agriculture to better handle expected changes but also serve to create synergistic effects between climate and development goals. The right measures could even help keep global temperatures in check. The sector contributes significantly to emissions-about 10 to 12 percent of human-made greenhouse gases (GHG) are produced by the agriculture sector. The sector is the main contributor of non-carbon dioxide greenhouse gases (e.g., methane), the primary source of agricultural emissions, coming from the digestive process of livestock and stored animal manure. It also emits large volumes of nitrous oxide from fertilizers, whereas the post-harvest stages of the production chain emit significant amounts of GHGs, as do food loss and waste (FAO 2015b).

Climate-smart agriculture (CSA), an expression coined by the Food and Agriculture Organization of the United Nations (FAO 2017b), pursues three main objectives-sustainable increase in agricultural productivity and income, greater resilience of food systems, and the reduction of emissions associated with agriculture - that may best help address climate change and meet development goals.

There are already ongoing efforts to engage business in CSA. The World Business Council for Sustainable Development (WBCSD) has launched an initiative to test large-scale projects in five pilot regions of the world (WBCSD 2015).

The US Agency for International Development (USAID) is working with the Sustainable Food Lab (Sustainable Food Lab 2019)—a global network of organizations looking to work towards a more sustainable food system-and coffee and cocoa partners, including private companies, to develop a learning community that provides business cases, strategies and action plans for the engagement of agribusiness in CSA.

The FAO has also launched the Global Alliance for Climate-Smart Agriculture (GACSA) to help create transformational partnerships on CSA. The Alliance is an action-oriented multistakeholder platform that brings together national governments, 
growers, scientists, business and civil society, as well as international organizations to discuss and learn about on-ground solutions and policy mechanisms combating climate change in the agricultural sector (GACSA 2014).

Lastly, the World Bank has been investigating supply chains (World Bank 2015) to highlight concrete examples of how farmers and food companies can work together to build more resilient models.

The critical challenge, though, is how to integrate business models when most potential actions increase costs and reduce returns in the short-term, while even the medium-term benefits remain uncertain. Who will finance or invest in the needed changes? Encouraging agribusinesses requires new incentives and perhaps a combination of hard and soft laws, including regulations and subsidies. We need to figure out how to introduce incentives that businesses will adopt: it is unlikely that the sector will make the necessary changes independently.

This paper aims to facilitate the business contribution to transforming agri-food systems to become more climate-smart. We lay out the threats, possible approaches and, finally, propose hard and soft policies that may help guide the sector into the right direction while promoting the United Nations' Sustainable Development Goals (SDGs) (UN 2015). It is critical for the business to play a role early on in this multistakeholder process: this will help ensure that the legitimate concerns of all actors are taken into account (WRI 2015). ${ }^{2}$

What is the best way then for the private sector to support this transformation? Business involvement can be founded on several areas of social and economic inclusion and environmental sustainability, and the SDGs provide a useful framework. They provided a breakthrough for businesses in providing a structure for guiding overall sustainability targets and indicators. SDGs help enterprises create principles, codes, and voluntary commitments to eradicate poverty and hunger, sustain responsible production and consumption, tackle climate change, and ultimately promote sustained, inclusive, and sustainable economic growth.

Sustained and inclusive economic growth (SDG 8) is a prerequisite for sustainable development and contributes to improved livelihoods, new and better employment opportunities, and greater economic security. The agriculture sector is the basis and

2 Partnerships will become increasingly essential for transformative goals, i.e., for those that tackle systemic problems, remove barriers, change established dynamics and implement long-term solutions. New models of cooperation are emerging based on multi-stakeholder platforms that facilitate the dynamics of collaboration between industrial actors, policymakers, academics, researchers and citizens. These models provide food for thought on how the involvement of a broad interdisciplinary audience can open up new opportunities for sustainable development (WRI 2015). 
the most vulnerable part of this growth, and transforming it to deal with new contexts and dramatic changes requires a more comprehensive vision that implies a broader transformation of the rural economy (WRI 2018; World Bank 2020). Addressing the socio-economic and environmental challenges related to climate change and making progress towards SDG 8 requires a concerted effort from all actors. Businesses have started to act in certain areas but, given the enormity of the challenge, need to do much more and need to be supported in their efforts by a system of policies and an enabling environment of multistakeholder collaborations.

\section{Threats of Climate Change to the Food and Agriculture Sectors}

A growing number of businesses fear that the effects of climate change may disrupt their supply chains and their ability to grow in a sustainable and profitable way. The biggest threats are likely to come from menaces to food security, nutrition, and human health, genetic resources, and agrobiodiversity ${ }^{3}$, and land degradation, as detailed below (Stockholm Resilience Center 2010). At the same time, the global food system is a significant emission contributor with up to a third of total emissions. The Global Sustainable Development Report (UN 2019b) clearly states that feeding the global population in 2050 under current agricultural practices poses significant threats to the Paris Agreement and other Sustainable Development Goals, while agriculture supports livelihoods and employs over 1.1 billion people (Independent Group of Scientists appointed by the Secretary-General 2019).

\subsection{Food Security, Nutrition and Human Health}

According to the FAO, food security relates to food availability, access, utilization, and supply-chain stability, and climate change threatens to undermine them all (FAO 2017a). Food availability will likely be affected by declining yields in the crop, livestock, fisheries, and aquaculture sectors. For instance, crop yields in Brazil could fall by up to 70 percent for soybeans and up to 50 percent for wheat with a warming of $2{ }^{\circ} \mathrm{C}$ (World Bank 2014a, 2014b). The IPCC warns that average yield reductions of 10 to 25 percent by 2050 could be widespread (FAO 2017a).

The International Food Policy Research Institute (IFPRI), in its report "Climate Change: Impact on Agriculture and Costs of Adaptation" (IFPRI 2009), predicts that

3 "The impact on biodiversity, along with nitrogen levels, has already entered the warning stage for surpassing what our planet can manage. These factors must be addressed jointly with climate mitigation and adaptation throughout the full value chain of the agricultural sector" (Stockholm Resilience Center 2010). 
rice productivity will decrease by $14 \%$ in South Asia, $10 \%$ in East Asia and the Pacific and $15 \%$ in sub-Saharan Africa by 2050. This would lead to price increases of between $32 \%$ and $37 \%$ (IFPRI 2009). The impacts will vary not only by crop but also by region depending on factors including latitude and irrigation. ${ }^{4}$ To give some examples, estimates suggest that the United States could see a $20 \%$ drop in corn production, particularly in mid-Western states, whereas Brazil's corn production could decline by nearly $16 \%$ by 2050 .

Some of the most significant impacts of global climate change will be felt in developing countries among "subsistence" or "smallholder" farmers. Their vulnerability stems both from being mainly located in tropical areas and from various socio-economic, demographic, and political trends that limit their ability to adapt to climate change. For instance, climate change can affect crop rotations, so growers have to consider new crop varieties, sowing dates, cropping density, and fertilization levels when growing crops to achieve sufficient yields for a growing population. These are all challenging pursuits for smallholders. Food accessibility will likely be hit by diminished purchasing power. This is because impacts on production have carry-on social and economic effects that come from fluctuations in agricultural incomes and prices, which also affect trade and investment. A proper evaluation of the economic cost of land degradation should also take into account factors including environmental vulnerability, demographic pressures, economic dependence on land, social and political instability, and the international context (Dupont 2015) and commitments, all of which can amplify the extent of the impact of degradation (UNCCD 2015).

Climate change is expected to have an impact on food utilization, mostly through food safety and health. ${ }^{5}$ It can reduce food safety by making food-borne diseases more widespread. It can also affect health in multiple ways, including geographical shifts in some diseases, heat stress, and natural disasters. The foreseen increases in the frequency and intensity of climate-related events are expected to undermine food stability. All of these effects are likely to affect nutrition by changing the composition of diets as well as available calories (Stockholm Resilience Center 2010).

4 If less water is available, soil better able to retain water will be more resistant to drought.

5 In general, climate change is likely to reduce food safety through a higher incidence of food-borne diseases. Climate also affects health via multiple pathways, including geographical shifts in vector-borne diseases, heat stress and natural disasters, which in turn affect the nutrition of people and their ability to provide care as well as nutritional contents of food. 


\subsection{Genetic Resources, Agro-Biodiversity, Water and Soil}

The number of crop varieties declined significantly in the 20th century, and intensive monoculture systems have expanded worldwide (FAO 2017a). These trends threaten adaptive capacity, increase genetic vulnerability and reduce nutritional diversity, leading in turn to lower resilience among agro-ecosystems and livelihoods (Bioversity International 2013; FAO 2020). ${ }^{6}$ This situation is further exacerbated by climate change: increased temperatures and the scarcity of water make it challenging to conserve both crop and wild plant genetic resources (FAO 2017a). ${ }^{7}$

Climate change also poses significant threats to natural resources that are vital for farming. Such damage and depletion undermine the ecological processes that support healthy, productive landscapes, and climate change may become the leading cause of biodiversity loss (WRI 2005). For instance, soils, the basis for plant growth, are deteriorating and are lost at significant rates due to the adverse effects of climate change. What is more, loss of soil fertility is associated with loss of carbon in the soil. This destabilizes the soil and reduces its buffer and storage capacity for nutrients and water; it also means that soil degradation is a source of carbon dioxide $\left(\mathrm{CO}_{2}\right)$ emissions. The loss of soil carbon reduces farmers' resilience to climate change and increases atmospheric $\mathrm{CO}_{2}$ (FAO 2017a).

\section{Addressing Climate Change in Agriculture}

Climate change is a global issue requiring locally adapted responses (FAO 2016b). Businesses must help make agricultural systems less vulnerable, secure the sustainable provisioning of food and support the livelihoods of those who produce it.

Addressing the threats mentioned above means transforming agri-food systems so that they become increasingly more efficient, use resources more wisely, and are more resilient to risks, shocks, and long-term climate variability while protecting and enhancing biodiversity (FAO 2017a). All actors in the value chain must also make efforts to reduce the emissions associated with the business itself. For instance, post-harvest phases use over 70 percent of the energy and release around 30 percent

6 It is estimated that of a total 300,000 plant species, 10,000 have been used for human food since the origin of agriculture. Out of these, only 150-200 species have been commercially cultivated of which only four-rice, wheat, maize and potatoes-supply 50 per cent of the world's energy needs, while 30 crops provide 90 per cent of the world's caloric intake (FAO 2010).

7 "Climate change is projected to significantly reduce renewable surface water and groundwater resources with particular intensity in most dry subtropical regions. Many regions are likely to face substantial water scarcity" (FAO 2017a). 
of the greenhouse gases of the entire agri-food value chains (excluding those resulting from land-use change) (FAO 2011; Garnett 2011). ${ }^{8}$ In addition, food loss and waste are responsible for about 8 percent of global GHG emissions (FAO 2015b, 2017b). If the sector can, at the same time, reduce carbon emissions and promote sequestration, such changes could represent an enormous opportunity to support both climate and development goals. While it is not clear who should pay in the face of low carbon prices, business needs to take a leadership and coordination role in dealing with the challenges. Hence, agriculture (SDG 2 coupled to SDG 15) has the potential to support a number of ecosystem services, including mitigation and adaptation to climate change, giving it a strong co-benefit leveraging effect across other SDGs such as SDG 13 , SDG 8 , and SDG 4.

Businesses using both adaptation measures and mitigation potential should advocate on behalf of food security and nutrition as well as environmental, social, and economic sustainability for growers at the global level. What is the best way to do this?

\section{Climate-Smart Agriculture Approach}

While many alternative sustainable strategies have been developed over the years, they all strive to maintain productivity and usefulness to society over the long run. Sustainability is a process rather than a prescribed set of practices and generally supports the convergence of all the available technologies and their use in solutions able to address local needs and societal requirements. In our opinion, attempts to maintain growing, predictable harvests with as little fluctuation as possible should not compromise the structural integrity or resilience of the production system. Management and conservation of resources such as soil and water should remain a priority while taking energy inputs into account.

The FAO's Climate Smart Agriculture approach has been introduced to guide the transformation of agricultural systems, safeguard food provisioning, integrate adaptation, mitigation, and food security. It provides an inclusive policy framework for a wide range of farming interventions in different contexts and could help us redesign and reorient agri-food systems to effectively support the development and

8 What are the best ways for reducing greenhouse gas emissions in the food system? The analysis done by Garnett showed that around half of the food sector emissions came from agricultural production, and the other half came from: manufacture of synthetic fertilizers (5\%), food processing (12\%), packaging $(7 \%)$, transport $(12 \%)$, retail $(7 \%)$, home food preparation $(9 \%)$, catering $(6 \%)$, food waste disposal (2\%) (Garnett 2011). 
safeguard food security in a changing climate (FAO 2017a). It aims to maximize benefits, pursue synergies and manage trade-offs across the three main CSA objectives of improving productivity, building resilience, and reducing emissions associated with agriculture.

The approaches could allow us to support an increase in crop productivity through the good management of soil, water, and biodiversity and help adapt the livelihoods of people likely to be affected by climate change. We can support agricultural practices contributing to reduced emissions, deforestation, and the degradation of land. The combination of soil and weather maps giving precise information about local meteorological conditions, soil type, and restorative need can help optimize local soil treatment to be more efficient, retain more carbon, reduce leakages of nutrition as well as improve water irrigation schemes.

Integrating Climate Smart Agriculture into business models could help the sector protect its supply chains, grow sustainably and profitably, all while meeting its commitments to reduce its impact on the environment. ${ }^{9}$ This could also address the concerns of some investors and large commercial banks beginning to establish strict investment criteria.

\section{How Businesses Can Contribute to Climate-Smart Agriculture}

What is the best way then for the private sector to support CSA? While it is clear that the private sector has a range of technologies, a depth of knowledge, and appropriate diagnostic tools and can help to channel substantial climate financing into agricultural systems, an overarching, coherent, and locally adapted approach is needed.

Business' involvement can be founded in several areas of social inclusion and environmental sustainability, and the UN's Sustainable Development Goals (UN 2015) provide a useful framework. They have provided a significant step forward for companies in delivering a framework to guide their overall sustainability objectives and indicators. SDGs help businesses create "soft laws" or business standards such as codes of sustainability, principles, and voluntary commitments to ensure that their operations are sustainable. CSA could help businesses to set targets that support SDGs: SDG 1 on ending poverty, SDG 2 on ending hunger; SDG 8 on economic

9 The World Business Council for Sustainable Development CSA initiative has convened a group of companies from the agri-food sector to address the double challenges of climate change and the need to meet the food needs of a growing world population (WBCSD 2015, 2020). 
growth; SDG 12 on responsible production and consumption, including the reduction of food waste; and SDG 13 on tackling climate change.

Climate change erodes food security, nutrition, poverty reduction, and sustainability in many ways, and agribusiness should be encouraged to focus its climate change strategy on improving food security and nutrition. Working within such a framework and following a harmonized approach for sustained, inclusive, and sustainable economic growth will require prioritized action. More concretely, agribusinesses can help support such goals in the following ways:

\subsection{Increase the Uptake of Digital Agriculture}

Consumer preference for sustainable food on the one hand and increasingly demanding access to capital on the other is putting pressure on farmers to manage their resources efficiently and accountably in order to maintain a competitive advantage over the long term.

Digital or precision agriculture - simply defined as translating agronomic advice into better and more precise execution of farm operations and applications to the field using equipment and machinery, usually through map-based digital systems-is one way in which they can do this. Digitalization can improve forecasting, diagnose pests and diseases, provide apps to measure wind speed, and improve spraying. In general, it gives us a chance to reach out to a vast number of farmers (WEF 2016).

Precision farming technologies, including the use of drones, soil sampling, probes, high-efficiency irrigation, and GPS-enabled machinery, could combine field and soil information with weather and product data to provide an integrated, intelligent strategy in the field. The customized, real-time, finely tailored, thoughtful insights gathered can help growers tackle intra-field variability, make smart choices on what to plant, when to plant, where to plant and what to apply to the plant and soil, and increase production efficiency while reducing resource degradation and carbon emissions.

Agribusinesses could help farmers adopt precision agriculture practices through consolidation across the food value chain, new cooperative ways of investing, and new finance and risk-sharing models that favor them. However, commercial models are mainly available, because of the required investments, in developed countries.

The opportunities to leapfrog current developments are, therefore, more significant in the least developed countries, but this will require new service delivery models that build on what is available to make innovations more accessible and affordable. This entails more investment and innovation, testing, and demonstrations. Famers will need to provide more data, but more data should also be made available 
to them. We will also require improved and tailored information services that offer longer-range weather forecasts and information on changing cropping and farming protocols.

\subsection{Build Smallholder Farmer Resilience}

Agriculture research companies need to develop specific technologies such as seeds that are more resistant to disease, drought, and flooding to meet the needs of smallholder farmers. For example, genetic advancement in certain crops well suited to small-scale farming, such as dietary staples including cassava, savory types of bananas, sorghum, and millet, could help promote food security in the context of a changing climate through local self-sufficiency and reliance. Doing this requires that agribusinesses include the correct measures in innovation scorecards so that they can make the right choices in the research and development process.

In addition to research, the sector could promote new business models and approaches to support smallholder farmers at all stages of the production value chain. There are many examples of new business approaches that fit the needs of smallholder farmers. These include finance and risk-sharing models, trading partnerships, small and affordable package sizes, and cooperative input distribution, models. Sustainably scaling up these models will provide new opportunities for agribusinesses.

\subsection{Promote Ecosystem-Based, Connected Landscape and Conservation Agriculture Approaches}

Ecosystems services help build resilience and mitigate the vulnerability to the effects of climate change on communities and their livelihoods. Integrating the protection of biodiversity and ecosystem services into adaptation and mitigation strategies and conserving genetic resources increases the resilience of food and agriculture systems to risks. Strategies to address climate change should be better aligned with attempts to protect biodiversity and ecosystems.

For instance, creating connected landscapes with healthy, functioning ecosystems can help rehabilitate degraded land and maintain the biological flows and infrastructure needed to increase the resilience of agriculture to drought and other climate impacts. Landscape connectivity would, therefore, not only help build resilience against climate change but also sharpen our attention and dedication to the triple goal of people, planet, and profit (De Vivo et al. 2016; WBCSD 2017).

In a similar way, no-till methods of soil management enhance the water retention capacity of the soil and prevent soil erosion by incorporating crop residues into 
the surface and minimizing carbon losses in the soil. They can also reduce the fuel consumption associated with cultivation by 60 to 70 percent (FAO et CABI 2006).

\subsection{Improve Nutrient Management}

Crops rely on soil nutrients (e.g., fertilizers, organic amendments, and N-fixation) and re-cycled inputs from the remains of crops left in the field. Optimizing fertilizer use efficiency in crop production can minimize nutrient losses to the environment while increasing nutrient delivery to the target crops. For example, the use of smart fertilizers can either delay the release of nutrients for uptake or transform nutrients into other forms that are less susceptible to loss. Categories of products that improve fertilizer efficiency include the controlled release of nitrogen fertilizers, nitrogen stabilizers, and phosphate management products. New services for efficient nutrient management may also be an opportunity and can consist of soil analysis (soil $\mathrm{pH}$ to optimize the availability of nutrients to crops, as well as organic matter), crop variety-optimized fertilizer application rates, and weather forecasts to optimize the application. Optimizing and supplementing the supply of nutrients to crops with fertilizers, the use of organic amendments, and the remains of crops/ cover crops left in the field are essential to soil health (FAO 2006).

\subsection{Reduce Food Loss and Waste}

Global food losses are enormous. The FAO estimates that about one-third of all cultivated food is lost due to pests, deterioration, waste, ineffective processing or transport, inefficient logistics, and consumer preferences (FAO 2017b). Businesses could encourage joint efforts and the prioritization of a framework for food loss and waste mitigation based on nutritional, environmental, and social indicators. This could help value chain actors such as those involved in packaging, processing, post-harvest handling, and distribution to evaluate options for reducing food waste along the value chain, taking into account infrastructure needs and constraints. It could also help businesses set standards and protocols for reducing food waste, as well as defining targets and action plans to achieve them. Since reasons for losses vary around the world, local and regional analyses should form the basis of any action plans.

In addition, the private sector, NGOs, and local authorities should help raise consumer awareness against food waste. One way of doing it is via food labeling and by supporting social awareness campaigns. It is also possible to use feedback loops to increase consumer understanding of who has produced the food and under what 
circumstances. This approach to traceability can address nutritional needs, as well as expand cultural approaches to food, facilitating access to more healthy diets.

Food waste poses as well substantial equity issues, more so when considering that food waste goes parallel, with 2 billion people suffering from food insecurity (Independent Group of Scientists appointed by the Secretary-General 2019).

\subsection{Seek Multistakeholder Support}

The CSA approach requires the assistance of multiple stakeholders to identify optimal interventions. They should, at the same time, take social, economic, and environmental constraints and opportunities through the entire food value chain into consideration (FAO 2017a). We nonetheless need to recognize that businesses are best organized through value chains in which all parties have something at stake.

Businesses could align with and seek the support of governments, academics, and civil society organizations at appropriate levels to roll out their CSA strategies. For instance, companies could engage with global climate-related initiatives such as the Global Alliance for Climate-Smart Agriculture to strengthen dialogue and partnership with NGOs and other stakeholders (Acosta et al. 2019; World Bank 2014a, 2014b; McCarthy et al. 2018). ${ }^{10}$

\subsection{Measure and Evaluate the Impact}

Businesses will also need to make an effort to measure and assess the actions they introduce as well as results achieved. This will involve gathering data and evidence to better inform policy and investment decisions on the links between food security, nutrition, and climate change (FAO 2019). Better knowledge and capacity to analyze the impacts of climate change on food security and nutrition and on agri-food can improve the measures taken.

Companies will need to support and strengthen decision-making based on the lessons learned from sectoral and cross-sectoral analysis of information, data, and knowledge. Common frameworks for measurement and outcomes should also be established (TFCFD 2017).

10 The list of global and regional multi-stakeholder initiatives is impressive, as is the diversity of fields of action and approaches: ISF, the Smallholders Finance Initiative; the World Cocoa Foundation; the Round Table on Sustainable Palm Oil; the Global Coffee Platform; and IDH, the Sustainable Trade Initiative; to name some, but a few. 


\subsection{Endorse Platforms to Share Knowledge and Foster Learning on CSA}

Businesses could help develop CSA knowledge-sharing platforms to facilitate learning and access to the latest information in the fast-evolving and multi-faceted field of climate change. These platforms, designed with partners throughout the value chain or with local authorities, could help to increase individual and collective awareness and knowledge, as well as improve education on mitigation, adaptation, impact reduction, and early warning for the private sector (CGIAR 2020). Companies might also set up agri-food centers to provide farmers with the necessary technology, education, and advice. These centers can be part of established state agricultural extension services or new units created to enable farmers to learn practices from each other. They could also help to achieve economies of scale by combining collection and storage from several farms. The centers allow new ideas, technologies, and business models to spread rapidly, and they can work with financial institutions to offer loans. The centers could also be used to provide timely weather information to promote improved on-farm weather monitoring and reduce risk. Tools to help farmers and advisors to see climate-related risks and potentials of their individual farms need to be further developed and made available to all farmers. This will include developing the capacity of institutions to collect data and the formation of international data and analysis to assist increasingly integrated and efficient agri-food systems (UNDP 2020).

\subsection{Build Innovative Financing Models to Support CSA}

According to the International Financial Cooperation, access to adequate financial resources is crucial for the creation of a market for CSA, but farmers rarely have access to credit, as the financial institutions regard them as a high risk. Adopting CSA requires up-front investment, which often takes time to lead to productivity gains. In addition, market premiums for sustainable products rarely offer adequate margins to finance climate-smart investment programs (IFC 2017). Businesses could help educate and encourage financial institutions on the business models for CSA to identify opportunities to increase investment. There is also a more general need for innovative financing and ways to cut risk. This could include first-loss facilities, insurance, capacity building, structured markets, social impact bonds, etc.

Farming should be understood as a provision of services rather than just food. By doing so, farmers could be incentivized and receive financial support for their actions towards ecosystem services. By doing so, policies activating this approach could actually cover a wide range of SDGs from "No Poverty SDG 1", "Zero Hunger SDG 2", "Good Health and Well-Being SDG 3", "Decent Work and Economic Growth 
SDG 8", "Climate Action SDG 13", "Life Below Water SDG 14", to "Life on Land SDG $15^{\prime \prime}$.

For this to happen, farmers and pastoralists need better regulation and access to markets, including infrastructure such as processing plants and producer cooperatives (Rueff and Rahim 2016). Adaptive capacities in adjusting market requirements to support quality farming and livestock producers may ease uncertainties and constraints for exporting farming goods. In the meat sector, for example, commodity-based trade allows healthy animals originating from foot and mouth contaminated areas to be exported nevertheless when deboned (Rueff and Rahim 2016).

\subsection{Introduce Index-Based Insurance}

Index-based insurance is a scheme covering smallholders for losses due to climate hazards. Policyholders are compensated according to an index of hazards (i.e., drought indices) and not on actual losses. This principle keeps an incentive for policyholders to still work towards saving their production and acting against a hazard when possible while being compensated, unlike conventional schemes. With conventional programs, policyholders would have no incentive to protect their output since the greater the losses, the higher the compensation (Rueff and Rahim 2016).

\section{Conclusions}

The agriculture sector is particularly vulnerable to potential threats from climate change and variation and must be prepared to adapt. Decisive measures could help agriculture face expected changes, help keep global temperatures in check and serve and create synergies between climate, development goals, and sustained inclusive growth.

Businesses have a significant potential to reduce greenhouse gas emissions and increase carbon sequestration in the soil while contributing to food security objectives and meeting key goals of human development. Boosting the operational efficiency and productivity of food production systems through improved technologies and better management practices can significantly contribute to reducing the footprint of global agriculture. To this end, agribusinesses should support and endorse the CSA approach to help small and large-scale farmers tackle changing climatic conditions by maximizing crop yields while using less land and non-renewable natural resources. The private sector can help by developing both conventionally bred and genetically modified seeds, chemical and biological pesticides as well as a range of adjacent technologies and practices. 
At the same time, addressing societal challenges related to climate change and making progress towards SDG 8 requires a concerted effort from all actors. Businesses have started to act in certain areas but, given the enormity of the challenge, need to do much more to support CSA and need to be supported in their efforts.

\subsection{Addressing Climate Change with Hard and Soft Laws}

We must pursue ambitious approaches to both adaptations and to cutting emissions. ${ }^{11}$ New public policies promoting CSA as a means of addressing such challenges are critical instruments for achieving collaboration and coherence in actions.

We argue that such policies should be developed in two parallel tiers. On the one hand, we need policies that directly target agricultural actors, stimulating farmers to implement appropriate mitigation and adaptation technologies and management practices. On the other, we need policies that create an enabling environment for other actors and sectors to contribute to the implementation of the CSA indirectly.

\subsection{Policies Directly Targeting Agricultural Actors}

These sorts of policy options can be grouped into those that rely on either legislative, economic, or social levers. Legal interventions allow for the introduction of requirements and mandatory management standards, pushing agricultural actors to adapt their technologies and management practices. Nonetheless, their efficiency in generating the necessary change depends on mechanisms, instruments, and tools to verify and ensure their enforcement. Options include setting rules on the management of resources (land, water, emissions) or managing the impacts on the environment and human health.

The economic lever can be used to create a pull effect on agricultural sector actors by providing compensation for additional costs or financial incentives to act in the desired way. The extent and scope of such policies are dependent on the public resources available and on the mechanisms in place to check the delivery of the desired results. They can be an excellent option to promote certain practices (e.g., conservation agriculture, biodiversity corridors, water harvesting, etc.) or can be considered when the change in agricultural practices delivers on certain public

11 Possible mitigation opportunities include land management, food loss and waste reduction and reducing emissions from land-use change and livestock. 
goods (e.g., food security, water management, pest control, landscape management, air quality, etc.).

Social-lever policies represent a softer approach and relying on raising awareness and education, in general, on the social organization of the community. While results are usually only visible over the long term, the impact is embedded in the fabric of society.

\subsection{Policies Creating an Enabling Environment}

We also need policies that create an enabling environment for other actors and sectors to indirectly contribute to the successful implementation of CSA.

Research and innovation policy has a vital role in developing new and improved solutions for agricultural production and for successfully contributing to the establishment of CSA. Such measures include adapting crops to new geographical zones or making them more resistant, developing machinery for precision agriculture, or IT systems that make better use of farming data and satellite technology. Their development should not rely solely on public research but also on new policies that encourage private companies to invest resources to develop economically sustainable products and technologies. To this end, companies must be provided with the appropriate economic and regulatory environment to allow them to control and manage the risks associated with such investments.

Appropriate policies should encourage and support public-private partnerships and multistakeholder collaboration platforms: they help spread the burden and reduce individual risks in the development of the appropriate solutions for the implementation of the CSA. Multistakeholder collaboration also enables the development of standards and guidelines necessary for implementing desired actions, all without creating risk imbalances in the value chain (Figure 1). 


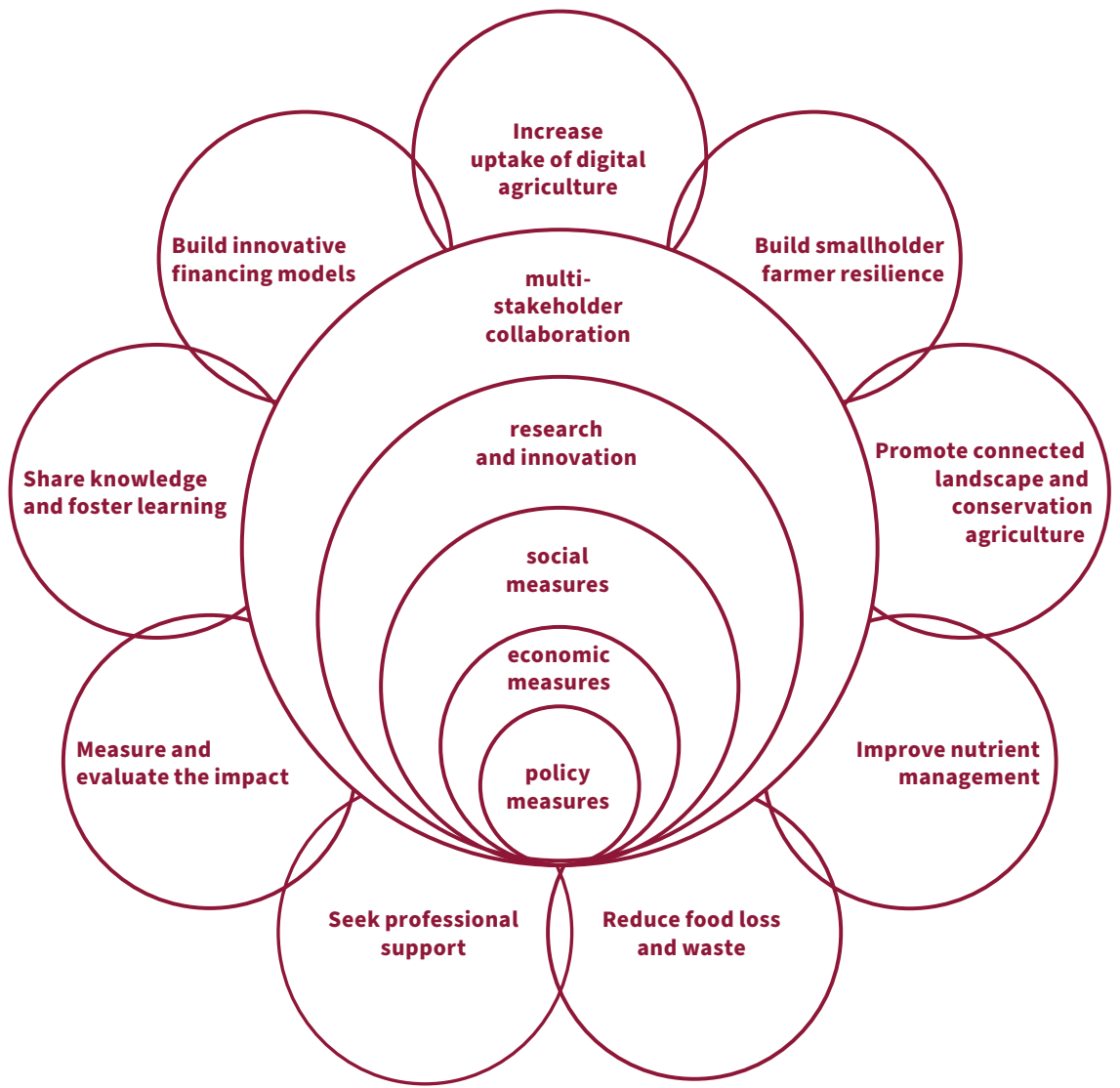

Figure 1. Elements that interplay in promoting CSA to addressing climate change and driving inclusive economic growth. Source: Figure by authors.

\subsection{Recommendations}

Given the complexity of the challenges related to climate change and the different ways in which agriculture can respond, a mix of policies should be considered. This will ensure a stable and fair common ground for all actors while encouraging them to adjust their strategies and operations to cope with the emerging threats.

At the country level, the recent adoption of the SDGs provides an opportunity to create such an enabling framework. Considering policy options for agriculture within a more general policy approach to making progress on the SDG 8 ensures that decisions are taken on a commonly accepted ethical and practical framework for individual and collective action. It also ensures that there is a common baseline. 
Companies should, therefore, consider aligning their strategies and operations to work towards the SDGs, thus acting in sync with the general objectives of society. In doing so, products, solutions, and technologies will be aligned to the future needs of their clients and will empower other actors and sectors to create sustained and inclusive economic growth benefitting us all.

Transformative change through the 2030 Agenda will likely be achieved by applying an SDG interconnectedness approach. Some SDGs do have a leveraging co-benefit effect, while others present trade-offs across a series of SDGs. Policy coherence and effectiveness will be achieved if food security and agriculture options take into account their strong leveraging effect, but also addressing the trade-off that they can have when it comes to climate change and land degradation, if not adopting a CSA approach (Pham-Truffert et al. 2020; Newell et al. 2019).

Author Contributions: All authors have contributed significantly and substantially to the intellectual content of the article. RDV played the role of the lead author by preparing the first draft. All co-authors have reviewed and approved the manuscript, at least as it pertains to their roles in the project.

Funding: This research received no external funding.

Acknowledgments: I would like to thank Isabelle Schluep (CCRS) for the review and valuable feedback on the manuscript.

Conflicts of Interest: The authors declare no conflict of interest.

\section{References}

Acosta, Mariola, Edidah Lubega Ampaire, Perez Muchunguzi, John Francis Okiror, Lucas Rutting, Caroline Mwongera, Jennifer Twyman, Kelvin M. Shikuku, Leigh Ann Winowiecki, Peter Läderach, and et al. 2019. The Role of Multi-Stakeholder Platforms for Creating an Enabling Climate Change Policy Environment in East Africa: Investigating the Business of a Productive, Resilient, and Low Emission Future. In The Climate-Smart Agriculture Papers. Edited by Todd S. Rosenstock, Andreea Nowak and Evan Girvetz. Cham: Springer, pp. 267-76.

Bioversity International. 2013. Diversifying Food and Diets: Using Agricultural Biodiversity to Improve Nutrition and Health. Available online: https://www.bioversityinternational. org/fileadmin/_migrated/uploads/tx_news/Diversifying_food_and_diets_1688_02.pdf (accessed on 15 May 2020).

CGIAR. 2020. Climate-Smart Agriculture 101. Available online: https://csa.guide/csa/contact\# main-index (accessed on 15 May 2020).

Chatzopoulos, Thomas, Ignacio Pérez Domínguez, Matteo Zampieri, and Andrea Toreti. 2020. Climate extremes and agricultural commodity markets: A global economic analysis of regionally simulated events. Weather and Climate Extremes 27: 100193. [CrossRef] 
De Vivo, Romano, Alexandru Marchis, Emilio J. Gonzalez-Sanchez, and Ettore Capri. 2016. The Sustainable Intensification of Agriculture. Solutions Journal 7, pp. 24-31. Available online: https://www.thesolutionsjournal.com/article/sustainable-intensificationagriculture/ (accessed on 15 May 2020).

Dupont, Cedric. 2015. Policy cycle: Developing a comprehensive approach. Paper presented at UNCCD COP12, Ankara, Turkey, 1 October 2015.

FAO. 2006. Plant Nutrition for Food Security: A Guide for Integrated Nutrient Management. Available online: http://www.fao.org/3/a-a0443e.pdf (accessed on 15 May 2020).

FAO. 2010. The State of Food Insecurity in the World Addressing food insecurity in protracted crises. Available online: http://www.fao.org/3/i1683e/i1683e.pdf (accessed on 15 May 2020).

FAO. 2011. Energy-Smart Food for People and Climate. Available online: http://www.fao.org/ docrep/014/i2454e/i2454e00.pdf (accessed on 15 May 2020).

FAO. 2015a. Voluntary Guidelines to Support the Integration of Genetic Diversity into National Climate Change Adaptation Planning. Available online: http://www.fao.org/3/a-i4940e. pdf (accessed on 15 May 2020).

FAO. 2015b. Food Wastage Footprint and Climate Change. Available online: http://www.fao. org/3/a-bb144e.pdf (accessed on 15 May 2020).

FAO. 2016a. Climate Is Changing. Food and Agriculture Must Too. Available online: http://www.fao.org/3/a-i5758e.pdf (accessed on 15 May 2020).

FAO. 2016b. The State of Food and Agriculture. Climate Change, Agriculture and Food Security. Available online: http://www.fao.org/3/a-i6030e.pdf (accessed on 15 May 2020).

FAO. 2017a. Strategy on Climate Change. Rome. Available online: http://www.fao.org/3/ai7175e.pdf (accessed on 15 May 2020).

FAO. 2017b. The Future of Food and Agriculture: Trends and Challenges. Available online: http://www.fao.org/3/a-i6583e.pdf (accessed on 15 May 2020).

FAO. 2019. Climate-Smart Agriculture and the Sustainable Development Goals: Mapping Interlinkages, Synergies and Trade-Offs and Guidelines for Integrated Implementation. Rome: FAO, Available online: http://www.fao.org/3/ca6043en/ca6043en.pdf (accessed on 15 May 2020).

FAO. 2020. Climate-Smart Agriculture Sourcebook. Available online: http://www.fao.org/climatesmart-agriculture-sourcebook/concept/module-a1-introducing-csa/chapter-a1-5/en/ (accessed on 15 May 2020).

FAO et CABI. 2006. No Tillage Seeding in Conservation Agriculture. Available online: http://www.fao.org/3/a-al298e.pdf (accessed on 15 May 2020).

GACSA. 2014. Strategic Plan 2018-2022. Available online: http://www.fao.org/3/CA1216EN/ ca1216en.pdf (accessed on 15 May 2020).

Garnett, Tara. 2011. Where Are the Best Opportunities for Reducing Greenhouse Gas Emissions in the Food System (Including the Food Chain)? Food Climate Research Network. Guildford: University of Surrey. 
IFC. 2017. Creating Markets for Climate Business: An IFC Climate Investment Opportunities Report. Available online: http://www.ifc.org/wps/wcm/connect/974eedcb-f3d9-4806b32e-73720e6f4ca7/IFC-Climate_Investment_Opportunity_Creating_Markets.pdf? MOD=AJPERES (accessed on 15 May 2020).

IFPRI. 2009. Climate Change: Impact on Agriculture and Costs of Adaptation. Available online: http://www.ifpri.org/publication/climate-change-impact-agriculture-and-costsadaptation (accessed on 15 May 2020).

Independent Group of Scientists appointed by the Secretary-General. 2019. Independent Group of Scientists appointed by the Secretary-General, Global Sustainable Development Report 2019: The Future Is Now-Science for Achieving Sustainable Development. New York: United Nations.

IPCC. 2014. Fifth Assessment Report. Agriculture Forestry and Other Land Use (AFOLU). in Climate Change 2014: Mitigation of Climate Change. Cambridge: Cambridge University Press, Available online: https://www.ipcc.ch/pdf/assessment-report/ar5/wg3/ipcc_wg3_ar5_ chapter11.pdf (accessed on 15 May 2020).

IPCC. 2019. Special Report on Climate Change and Land. Available online: https://www.ipcc. $\mathrm{ch} / \mathrm{srccl} /$ (accessed on 15 May 2020).

McCarthy, Nancy, Leslie Lipper, and David Zilberman. 2018. Economics of Climate Smart Agriculture: An Overview. In Climate Smart Agriculture. Building Resilience to Climate Change. Edited by Nancy Leslie, Nancy McCarthy, David Zilberman, Solomon Asfaw and Giacomo Branca. Cham: Springer, vol. 52, pp. 31-47. [CrossRef]

McKinsey and Company. 2015. Investing, vol. 2, Global Agriculture's Many Opportunities. Available online: http://bit.ly/2k47dCk (accessed on 15 May 2020).

Newell, Peter, Olivia Taylor, Lars Otto Naess, John Thompson, Hussein Mahmoud, Patrick Ndaki, Raphael Rurangwa, and Amdissa Teshome. 2019. Climate Smart Agriculture? Governing the Sustainable Development Goals in Sub-Saharan Africa. Frontiers in Sustainable Food Systems. Available online: https://www.frontiersin.org/ articles/10.3389/fsufs.2019.00055/full (accessed on 15 May 2020).

Pham-Truffert, Myriam, Florence Metz, Manuel Fischer, Henri Rueff, and Peter Messerli. 2020. Interactions among Sustainable Development Goals: knowledge for identifying multipliers and virtuous cycles. Sustainable Development. In press. [CrossRef]

Rueff, Henri, and Inam Rahim. 2016. Enhancing the economic viability of pastoralism: The need to balance interventions. Revue Scientifique et Technique 35, pp. 577-86. [CrossRef] [PubMed]

Stockholm Resilience Center. 2010. Planetary Boundaries. Available online: http://www. stockholmresilience.org/research/planetary-boundaries.html (accessed on 15 May 2020).

Sustainable Food Lab. 2019. Available online: https://sustainablefoodlab.org/the-climatesmart-agriculture-papers/ (accessed on 15 May 2020). 
TFCFD. 2017. Climate-Related Financial Disclosures. Available online: https://www.fsb-tcfd. org/ (accessed on 15 May 2020).

UN. 2015. Sustainable Development Goals (SDGs). Available online: http://www.un.org/ sustainabledevelopment/sustainable-development-goals/ (accessed on 15 May 2020).

UN. 2019a. Climate change and poverty: report of the Special Rapporteur on Extreme Poverty and Human Rights Human Rights Council. Special Rapporteur on Extreme Poverty and Human Rights. Available online: https://digitallibrary.un.org/record/3802219? ln=en (accessed on 15 May 2020).

UN. 2019b. The Future Is Now. Science for Achieving Sustainable Development. Global Sustainable Development Report. Available online: https://sustainabledevelopment.un. org/content/documents/24797GSDR_report_2019.pdf (accessed on 15 May 2020).

UNCCD. 2015. Land Matters for Climate Reducing the Gap and Approaching the Target. Bonn: UNCCD.

UNDP. 2020. Multistakeholder Collaboration for Systemic Change: A New Approach to Strengthening Farmer Support Systems. Available online: https://www.undp.org/content/undp/en/home/librarypage/environment-energy/

multi-stakeholder-collaboration-for-systemic-change--a-new-appro.html (accessed on 15 May 2020).

WBCSD. 2015. CSA Initiative. Available online: https://www.wbcsd.org/Programs/Foodand-Nature/Food-Land-Use/Scaling-Positive-Agriculture/Resources/Climate-SmartAgriculture-accelerating-progress-towards-the-Paris-Agreement (accessed on 15 May 2020).

WBCSD. 2017. Landscape Connectivity: A Call to Action. Available online: http://www.wbcsd.org/Projects/Climate-Smart-Agriculture/Resources/LandscapeConnectivity-A-call-to-action. (accessed on 15 May 2020).

WBCSD. 2020. CSA Initiative. Smarter Metrics for Climate Change and Agriculture: Business Guidance for Target-Setting across Productivity, Resilience, and Mitigation. Geneva: WBCSD. WEF. 2016. How Digital Is Solving 3 Problems in Agriculture. Geneva: WEF.

World Bank. 2014a. Turn down the Heat: Confronting the New Climate Normal. Washington: World Bank.

World Bank. 2014b. Increasing the Effectiveness of Multistakeholder Initiatives through Active Collaboration. Washington: World Bank.

World Bank. 2015. Resilient Supply Chains_Farmers \& Food Industry Tackle the Shared Challenge of Climate Change-A Strategic Dialogue. Washington: World Bank.

World Bank. 2020. Harvesting Prosperity: Technology and Productivity Growth in Agriculture. Washington: World Bank.

WRI. 2005. Millennium Ecosystem Assessment, Ecosystems and Human Well-Being: Biodiversity Synthesis. Washington: Island Press. 
WRI. 2015. Global Multistakeholder Partnerships: Scaling up Public-Private Collective Impact for the SDGs. Available online: https://sustainabledevelopment.un.org/content/ documents/1738Global\%20Multistakeholder.pdf (accessed on 15 May 2020).

WRI. 2018. Transforming Agriculture for Climate Resilience: A Framework for Systemic Change. Washington: WRI.

(C) 2021 by the authors. Licensee MDPI, Basel, Switzerland. This article is an open access article distributed under the terms and conditions of the Creative Commons Attribution (CC BY) license (http://creativecommons.org/licenses/by/4.0/). 

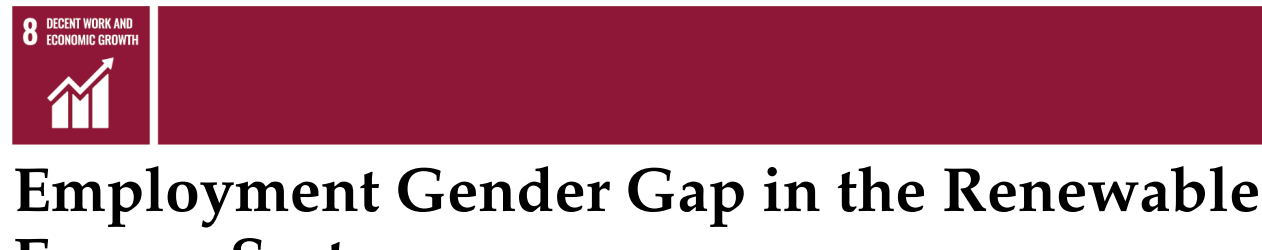

\title{
Employment Gender Gap in the Renewable Energy Sector
}

\author{
Sumon Vangchuay and Amanda Niklaus
}

\section{Introduction}

Energy transformation is increasingly perceived as the pathway towards a more inclusive and sustainable future. The accelerated global deployment of renewable energy sources is believed to create jobs, reduce poverty, improve human welfare, reinforce gender equality and lead to some form of societal re-structuring and "systemic change", through which societies can become more fair and inclusive (IRENA 2016, 2019a, 2019b and 2020). To that end, renewables are mentioned as instrumental in meeting the targets of UN Sustainable Development Goals (the SDGs) which nation-states have committed to delivering by 2030 (e.g., CCSI et al. 2019).

In the context of the SDG 8 (Promote sustained, inclusive and sustainable economic growth, full and productive employment and decent work for all), we investigate the premise of the claim that the renewable energy sector will provide "important opportunities for greater inclusion and equality" (IRENA 2019a). In assessing such opportunities, we examine (1) the rationale for gender equality under SDG 8 and (2) the connections with SDG 5 (Achieve gender equality and empower all women and girls) and, to a lesser extent, SDG 7 (Ensure access to affordable, reliable and sustainable modern energy services for all). Lastly, we discuss (3) the gender gap in the renewables workforce and specific challenges facing women in their renewable energy jobs and employment.

\subsection{Background and Knowledge Gaps—Gender and Energy}

For the purpose of this study, we categorized the literature on energy transition into two broad aspects of change: technical and socio-politico. The technical change covers specialized questions related to the technology and economics of energy sources of the society (e.g., Odum 1971; Elliott 1997). Proponents of technical energy transition range from those advocating for a minor shift in the use of fossil fuel to those fully committed to a complete transition to $100 \%$ carbon-free renewable energy system (e.g., Jacobson and Delucchi 2009). Energy transition movements are supported by different socio-political groups who advocate effective policy awareness campaigns with the promise of more sustainable renewable-based 
systems (e.g., EU 2002; WEC 1994) and the fundamental change to the energy system (Stephens 2019).

Social scientists have only until recently begun to inquire into complex social dynamics required to achieve energy transformation (e.g., Fri and Savitz 2014; Berkhout et al. 2012). The transformative potential of renewable energy is often reinforced by the so-called energy democracy movement which connects energy system change to a liberal agenda of social justice and equality (e.g., Burke and Stephens 2018). Central to such a movement is the incorporation of new voices and relevant "social logics" from diverse stakeholders into the energy transition debate (Pearl-Martinez and Stephens 2017; IUCN 2015). Because diversity and inclusion may hold the key to the success of energy transition, gender has been widely documented as one critical factor informing more sustainable responses to climate and energy challenges (e.g., Nagel 2015).

However, the question of gender in the energy sector has only evolved as "a late bloomer" (Clancy 2009), compared to the far more prolific literature on gender and the environment or in sustainable development. Few studies in the early 1990s explored relationships between gender and renewable energy (Farhar 1998) as well as the issues of gender in energy policy and economic development (Parikh 1995). Subsequent studies examined the concepts and issues concerning gender and energy (Clancy and Khamati-Njenga 2003), gendered use of energy in the household in developing countries (Räty and Carlsson-Kanyama 2010; Carlsson-Kanyama and Lindén 2007), how to integrate gender into energy policy (Clancy and Feenstra 2006) and the lack of gender awareness in the development of energy systems (Clancy 2009). In contrast to the environmental and economic benefits of alternative energy sources, social and labor dimensions were much less studied. Prior to 2010, research on gender and the energy workforce was very limited.

Within the last decade, the gender issue in the renewable energy workforce received more research attention. Topics include women's occupational patterns in renewables jobs (Baruah 2016), the value and benefits of gender diversity (Pearl-Martinez and Stephens 2017) and women's professional development, for example, via networking organizations (Allison et al. 2019). The visible role of women in renewable energy deployment and access is now documented and being measured against progress in the context of the ongoing energy transformation (IRENA 2016, 2019a, 2020).

Nonetheless, there is little research on the gender gap in the renewables sector in the context of SDGs. In particular, we found a knowledge gap in understanding why gender should be a compelling rationale for an inclusive energy transition workforce 
under SDGs, particularly under SDG 8 (and SDG 7). Given a weak underpinning of gender and labor rights under SDG 8 (Rai et al. 2019), mobilizing a gender-inclusive workforce for energy transition on a large scale is questionable. The authors aim to bridge this knowledge gap and to better understand the gender rationale behind the renewable energy transition under the SDGs.

\subsection{Object of the Study}

The main objective of this study is to examine the gender gap and assess an outlook for gender equality in the renewable energy workforce under SDG 8 by answering the following three questions:

(1) How are (gender) equity and inclusion considered under SDG 8?

(2) How is SDG 8 (and SDG 7 to an extent) related to SDG 5?

(3) What is the extent of a gender gap in the renewable energy workforce and what are the main challenges and difficulties facing women in their renewable energy jobs and employment?

\section{Materials and Methods}

To answer the above questions, we employed mixed-methods research combining quantitative and qualitative data analysis through a literature review, desk research and a qualitative survey.

\subsection{Methodology}

We used literature review and desk research to analyze primary and secondary data on the issue of equity/diversity under SDG 8 (Section 3) as well as on the situation of women in the renewable energy employment context (Section 4).

In answering the third question, we supplemented our desk research on the gender gap and challenges facing women in the energy workforce with qualitative survey results gathered from a semi-structured questionnaire and interview (Section 4). We used a small sample of the target population, namely, women currently active in the renewable energy workforce. We adopted this "gender" approach in order to collect and understand the perception and situation of women in the renewable energy workforce as a precursor to subsequent studies where the views of both men and women in the sector should be collected through a larger sample size.

Our 30 anonymized respondents came from renewable energy network partners, comprising national and international women's groups and associations in the renewable energy sector (see Acknowledgments). 
The demographic information of the sample obtained is outlined by age group, level of educational background, company size, years of work experience and level of seniority in their company. Figure 1 shows the demographic composition of our survey respondents.

The majority of the respondents are between 24 and 40 years old (71\%), obtained a postgraduate level of education or higher $(79 \%)$, have more than 6 years of experience in the energy sector (56\%), currently work in small- and medium-sized enterprises with less than 250 employees (63\%) and hold a senior level position within their respective company (53\%).

Our questionnaire, comprising 16 closed and open-ended questions, was designed to collect demographic information as shown above and obtain attitudinal and anecdotal information on the following topics:

1. Main reason(s) for a low share of women in the renewable energy sector;

2. Challenges, if any, in their career entry and advancement;

3. Their view on women in leadership positions within the sector;

4. The existence and their perception of "glass ceiling";

5. Three personality traits necessary for career success in the sector.

The results were initially grouped into broad categories, i.e., positive, negative, and neutral. Key words and phrases were delineated by recurring themes of gender gap and challenges in the energy workforce and weaved into our line of argumentation in Section 4.

\subsection{Structure of Arguments}

This paper is structured into two parts: First, we discuss the rationale for pursuing a more gender inclusive energy transition under SDG 8 and the relations to SDG 5 (and SDG 7, when relevant). Second, we examine the situation of women and a gender gap in the renewables workforce, supplemented by qualitative information on women's perception of the gender gap and the difficulties they face at different stages of their career. Finally, we draw key conclusions and provide outlook and recommendations. 
(a) Age: $45 \%$ of survey respondents were between 30 and 40 years old.

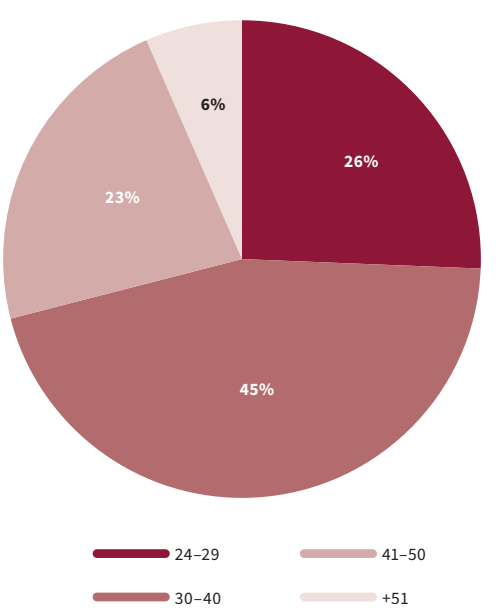

(b) Education: $76 \%$ of survey respondents had a Master's degree.

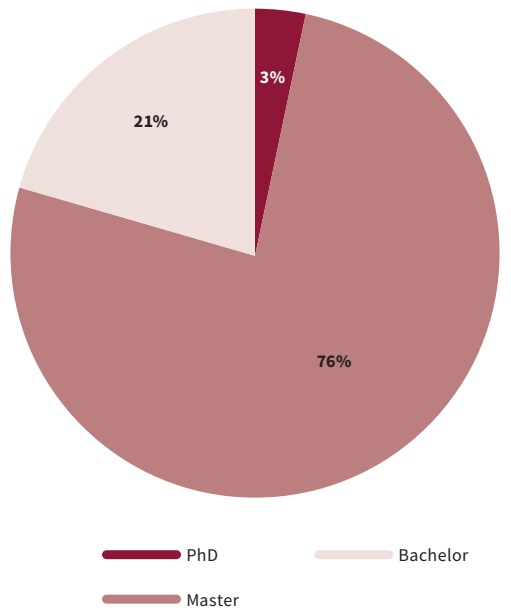

(c) Firmographics: Respondents' company size by number of employees.

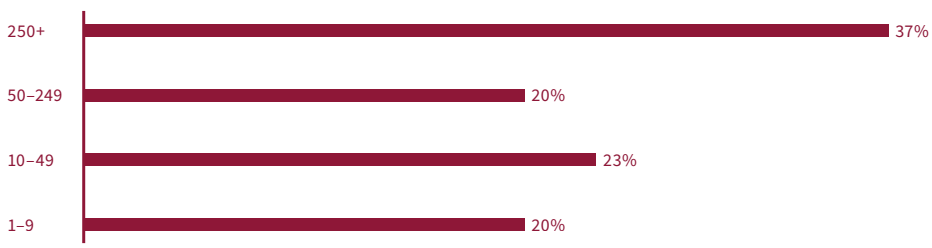

Figure 1. Cont. on next page. 
(d) Respondents' years of experience in the energy sector.

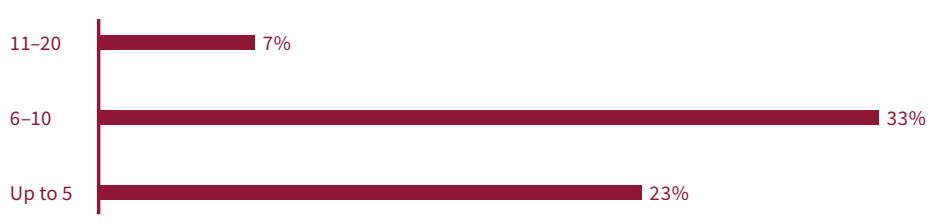

(e) Level of seniority of respondents.

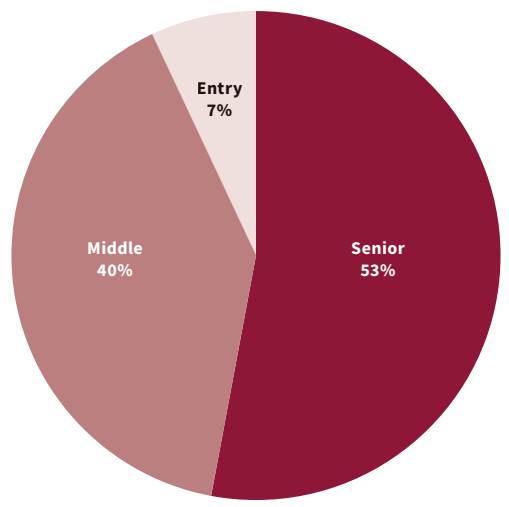

Figure 1. Demographics of the survey: (a) age, (b) education, (c) firmographics, (d) experience and (e) seniority. Source: Figure by authors.

\section{Rationale for Gender Inclusive Energy Transition under SDG 8}

Our first question concerns the relevance of equity/inclusion under SDG 8. To answer this, we first examine how issues of equity or equality are considered in the target requirements under SDG 8 . Then, we place SDG 8 in the context of overall SDGs and the extent to which SDG 8 is linked to SDG 5 (on gender equality) and SDG 7 (on sustainable energy).

Under SDG 8, the renewable energy sector can contribute to meeting its twelve targets in two broad areas: (i) economic growth and (ii) expanding employment. To underline relationships between the two, we adopted a three-dimensional approach to welfare (economic, social and environment) (Giannetti et al. 2015; Chancel et al. 2014) to assess gender equality considerations under SDG 8 . We then examined the rationale behind the SDG 8 primary measurement for "Decent Work and Economic Growth", namely, Gross Domestic Product (GDP), and assessed whether the approach to welfare under SDG 8 has a gender implication for the energy sector. 


\subsection{Macroeconomic Growth of Renewables}

Renewable energy offers solutions not only to meet energy demand while reducing carbon emissions but also to boost to the economy and productivity through innovation and diversification (WEF 2012). As an economic sector, renewable energy contributes to the economy in two major ways. First, jobs and value are created from within the sector by transforming and distributing energy goods and services. Second, its value chains potentially affect the creation and procurement of all products and services, thus supporting economic activities across sectors of the entire economy (WEF 2012). On the surface, the promise of a successful energy transition can enable the meeting of many targets under SDG 8, particularly, Targets 8.1, 8.2, 8.3 and 8.4.

The "economic growth" aspects of SDG 8 are primarily measured by traditional economic indicators, such as GDP (Target 8.1); diversification; technological upgrading and innovation (Target 8.2); growth of micro-, small- and medium-sized enterprises (Target 8.3); and decoupled economic growth from environmental degradation (Target 8.4). Given that the macroeconomic impacts of the renewable energy sector will be measured mainly through GDP, data are encouraging for the sector. With the global average of $6 \%$ share to the GDP of the whole energy sector, renewable energy's projected impact on GDP growth ranges between 0.2 and $4 \%$ (IRENA 2016; Statista 2015; WEF 2012).

Renewable energy correlates positively with GDP growth in two ways: (1) increased capital formation (Chien and $\mathrm{Hu} 2008$ ) and (2) cost-effectiveness and investment attraction. Renewable technologies have been shown to lower costs related to energy use or power bills compared to plant capital (Warr and Ayres 2009). Moreover, renewables are an increasingly attractive choice of investment and diversification due to revenue-generating opportunities through its value chains. An increasing share of renewables at all levels can positively affect the global economy through power prices, investment, and trade (e.g., IRENA 2016).

In reality, however, the economic benefits of the renewable energy transition in terms of GDP will vary depending on other factors influencing the economic structure and composition of the available workforce. The target of a minimum $7 \%$ annual growth in GDP under SDG 8 set no parameters for measuring or linking to sustainable human socio-economic development. The measurement of GDP should involve other measures for decent work, such as employment rate, and other broader measures of sustainability and welfare, such as equality and inclusion (Coscieme et al. 2020). While some countries (such as Sweden) have implemented SDG 8 targets to positively influence the other SDGs (Weitz et al. 2018), many countries and organizations, such as the European Union (EU), have treated GDP as a separate measurement from 
other welfare and equality dimensions (Coscieme et al. 2020). This separate treatment could mean that pursuing SDG 8 with the sole view of GDP can be disconnected with indices on sustainability and welfare, such as equality and inclusion, contradict gender goals and goals on reducing other socio-economic inequalities. Depending on how one links GDP to other equality measurements, the growth of the renewables sector under SDG 8 can have little implication for gender equality.

\subsection{Expansion of Employment and Human Welfare}

Under SDG 8, the "decent work" aspects can be measured by a broad measurement of labor and employment, including "full and productive work for all", "equal pay for equal work value" (Target 8.5), youth employment (Target 8.6), elimination of forced labor and child labor (Target 8.7), working conditions (Target 8.8), sustainable tourism (Target 8.9), access to financial services (Target 8.10) and two supplementary targets on trade support for LDCs (Target 8.a) and global job strategies (Target 8.b).

Growing evidence indicates that renewable energy improves broader socio-economic and human welfare well beyond GDP, particularly in terms of job growth, well-being and human development (WEF 2012). Doubling the share of renewable energy deployment by 2030 projects a $2.7 \%$ increase in global welfare, compared to $0.6 \%$ GDP improvement (IRENA 2014, 2016). The global welfare is projected to be higher through heating electrification and transport, improving $3.7 \%$ compared to $1.1 \%$ GDP (IRENA 2016). Because of a demand for labor in the production and distribution of renewable energy (Wei et al. 2010), renewable energy has created new employment opportunities (formal and informal) while addressing energy scarcity in remote communities. The strongest improvement in human welfare can already be seen across developed countries (such as the US, Australia and Japan) and developing countries (such as India, Ukraine, Indonesia, South Africa and China) (IRENA 2016, 2019b).

According to the 2017-2018 data, renewable energy (including hydropower) is responsible for nearly 11 million direct and indirect gross jobs worldwide, a jump from 7.1 million in 2012 (IRENA 2019b). The strongest job growth has been in the solar photovoltaics (PV) industry, accounting for about 3.6 million jobs concentrating in China, Brazil, USA, India and the EU (see Table 1). Other employers in the sector include wind, hydropower, bioenergy and solar heating and cooling (SHC) (IRENA 2019b). 
Table 1. Direct and indirect jobs in renewable energy, 2017-2018.

\begin{tabular}{ccccccc}
\hline Technology & World & China & Brazil & USA & India & EU \\
Solar PV & 3605 & 2194 & 15.6 & 225 & 115 & 96 \\
Liquid biofuels & 2063 & 51 & 832 & 311 & 35 & 208 \\
Hydropower & 2054 & 308 & 203 & 66.5 & 347 & 74 \\
Wind power & 1160 & 510 & 34 & 114 & 58 & 314 \\
Solar thermal heating/cooling (SHC) & 801 & 670 & 41 & 12 & 20.7 & 24 \\
Solid biomass & 787 & 186 & & 79 & 58 & 387 \\
Biogas & 334 & 145 & & 7 & 85 & 67 \\
Geothermal energy & 94 & 2.5 & & 35 & & 23 \\
Solar thermal power (CSP) & 34 & 11 & & 5 & & 5 \\
Total & $\mathbf{1 0 , 9 8 3}$ & $\mathbf{4 0 7 8}$ & $\mathbf{1 1 2 5}$ & $\mathbf{8 5 5}$ & $\mathbf{7 1 9}$ & $\mathbf{1 2 3 5}$ \\
\hline
\end{tabular}

Source: adapted from @ IRENA (2019b).

China provides the most renewables jobs, accounting for more than 4 million people. Its PV industry employs nearly 2.2 million people, $80 \%$ of them work in manufacturing that produces $70 \%$ of the world's panel production. Brazil comes in second place with over 1.1 million jobs, mainly in liquid biofuels. The US is the third-largest employer, covering 800,000 renewable-related jobs, mainly in solar, wind and bioenergy, respectively. Next is India with over 700,000 million people in renewables jobs. The European Union has more than 1.2 million renewable energy jobs (including waste-to-energy), mainly in Germany and France (IRENA 2019b).

The share of renewable energy jobs, both direct and indirect employment, is projected to double to 24.4 million by 2030 (IRENA 2016). Replacing fossil fuels with renewables will lead to job growth across all technologies, particularly in technologies with today's already high employment rate, i.e., solar, bioenergy and hydropower. Compared with coal or natural gas, solar PV creates $100 \%$ more jobs per unit of electricity generated. Most jobs will come from installations, manufacturing and bioenergy feedstock supply in new markets (IRENA 2016). In major economies, job growth will concentrate in the skilled trades with high demand for environmental professionals in science and engineering, law and finance (e.g., U.S. Bureau of Labour Statistics 2017).

Because of its job growth potential, the renewable energy sector becomes a valuable vehicle for achieving broad welfare objectives. Various dimensions of green energy employment-including policy development, education and training-must be assessed when judging a successful energy transition for the society as a whole (Strietska-Ilina et al. 2011; UNIDO and GGGI 2015). 


\subsection{Diversity and Inclusion under SDG 8}

We consider SDG 8 crucial for a renewable energy transition because of the influence it has on many other SDGs. Based on the wording of its twelve targets, SDG 8 ranks among the top three most interconnected SDGs out of the 17 Goals (Le Blanc 2015). In other words, meeting the targets of SDG 8 in the themes of "sustained, inclusive and sustainable economic growth" and "full and productive employment and decent work for all" is essential to the success of SDGs in their entirety.

However, equity and inclusion seem to be a missing link under both SDG 8 and SDG 7, the two SDGs crucial for the inclusive and sustainable energy transition. While the linkages among targets of the two SDGs can be seen between energy use efficiency (7.3), economic diversification (8.2), and resource efficiency and decoupling economic growth from environmental degradation (8.4), it is unclear how to facilitate inclusive growth from energy transition without addressing existing disparities in the energy workforce. Given a significant deficit in remote areas of Africa and Asia, addressing issues of equity and inclusion in the areas of employment and sustainable energy can significantly improve the livelihoods of millions of women, men and children. Under SDG 7, gender has not received consistent attention among member states, even when progress on accelerating gender equality in all areas is among the required reporting guidelines for SDGs (UN GA 2015). As stated in the analysis of 2018 national reports on SDG 7, the linkages between SDG 5 (gender equality) and SDG 7 are "rarely spelled out" in the country-level reviews (UN DESA 2018a; UN DESA 2018b).

Furthermore, conceptual tensions between SDG 8 and SDG 5 can be observed. SDG 8 emphasizes growth through GDP and productive employment in the formal sector, while SDG 5 emphasizes the equitable value and recognition of women's social reproductive and care work, as well as domestic work. Despite a growing body of labor research indicating that the two forms of labor are often connected (Rai et al. 2019; Runyan 2016), prioritizing the formal labor sector can obscure much of women's true contribution to the economy. The GDP growth benefits mentioned in Section 3.1 above are projected as a best-case scenario, whereby more women are integrated into industry and service sectors (MGI 2015). However, it is unclear how these indicators will address inequalities in the world of work and bring women into the formal sector.

In the energy sector, women in emerging and developing economies are employed in informal activities ranging from procuring fuelwood, to producing charcoal, to traditional biomass and fuel-crop (IRENA 2020). Millions of Sub-Saharan 
African women are arguably engaged formally or informally in the biomass sector (Baruah 2016). The production of fuel crops and biofuels at the village level is also an important source of renewables employment for women in countries such as India (ENERGIA 2009).

Furthermore, traditional economic targets, such as GDP, do not account for unintended consequences of pursuing too narrow a GDP growth (Fioramonti et al. 2019; Fioramonti 2013, 2017). The narrow pursuit of economic growth without other human indices linked to GDP has been linked to negative impacts on the environment, health and social relationships, exacerbating the exploitation of labor and female forced labor in particular, and further widening inequalities (Spaiser et al. 2017). The narrow rationale for economic growth under SDG 8 can reinforce occupational segregation by sex and prevailing gendered norms already existing in the energy labor market (Rai et al. 2019).

The principle of equal pay for work of equal value (SDG 8.5) has an obvious gender equity component. This principle is drawn from the ILO's practice under its convention on the subject (Equal Remuneration Convention, No. 100) and focuses on the "value" of work performed rather than the "equal pay for equal work". SDG 8.5 indicators, which focus on the average hourly earnings of female and male employees and the unemployment rate by sex implying the "equal value" of the work performed by women, are not linked to targets and indicators of SDG 5 or SDG 7 (Rai et al. 2019). This principle of equal remuneration for men and women for work of equal value is the only equity consideration under SDG 8.

It should be noted that the ILO has developed a sophisticated understanding of gender equality drawing from its own practices under relevant labour conventions on non-discrimination, equal remuneration and maternity, among others (ILO NORMLEX 2020). The ILO also recognized gender equality in both formal and informal labor (including unregulated and subcontract work) and paid domestic work. With the exception of equal pay, it is unclear how equality practices of the ILO are translated into "decent work" or "inclusive growth" under SDG 8.

The above-mentioned issues led us to cast doubt on achieving an inclusive energy transition workforce under the SDG 8 framework. Not only is the rationale for pursuing gender inclusiveness through SDG 8 not reflected in its main targets and indicators, there are also tensions between SDG 8, SDG 7 and SDG 5. When the equity/inclusion dimensions are not required in the energy transition, the socio-economic benefits of energy transition can hinder progress toward gender equality and widen existing gaps. 


\section{Renewable Energy Workforce: Gender Gap and Key Characteristics}

Gender disparities are specifically apparent within the energy labor market (Ernst and Young 2015; Price Waterhouse Coopers PwC). In this section, we outline some of the most salient themes characterizing the share of women in the renewable energy workforce: (i) growing number of women in renewables workforce compared to oil and gas; (ii) underrepresentation in specialized, technical and leadership roles; (iii) barriers in the three stages of employment; (iv) gender pay gap; (v) lack of gender awareness; and (vi) lack of data and measurement.

\subsection{The Share of Women in Renewables Workforce: A Mixed Picture}

A recent study conducted by IRENA reported 32\% female employment in the renewable energy workforce worldwide (IRENA 2019a; Lallement 2013). When compared to other industries, that amount decreases to $19 \%$ (see Figure 2).

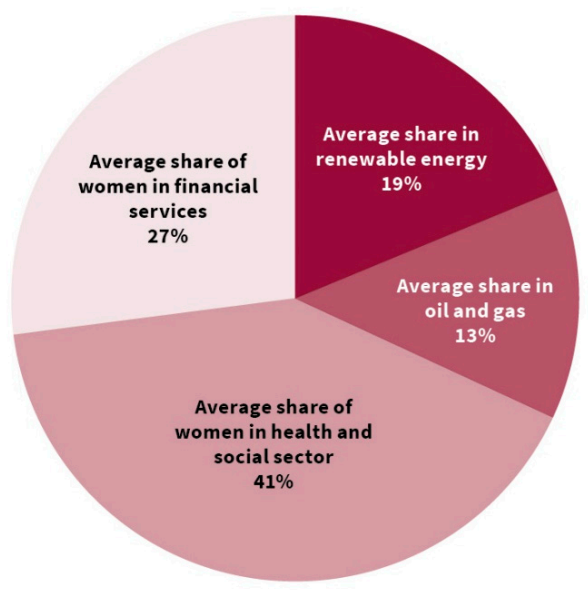

Figure 2. Share of women in the renewable energy sector compared to other sectors. Source: adapted from (C) IRENA (2019a) (Boniol et al. 2019; WEF 2017); used with permission.

A relative increase in women in renewables employment compared to that of the shrinking oil and gas sector is part of a workforce transition trend in the digital and technological age which requires 40-160 million women (7-24\%) and 60-275 million men (8-28\%) to switch occupations by 2030 (Madgavkar et al. 2019). Women have increasingly navigated outside their traditional female-dominant sectors (such as 
healthcare, humanities and social science). They are drawn to the renewable energy sector that offers some "unprecedented" opportunities for women due to its demand for a multi-disciplinary and diverse workforce (IRENA 2019a) coupled with prosocial, humanist aspirations (Allen et al. 2019; Lucas et al. 2018).

However, the $32 \%$ share of women in renewables jobs is still much below the $47 \%$ average of the global workforce in 2019, and even lower when compared to 56 and 51\% in the US and the EU, respectively (ILOSTAT and World Bank 2020). Among popular technologies, progress is uneven. Solar PV became the largest source of renewables employment for women in industrialized countries. In the US, women represented $26.3 \%$ of the solar workforce (Solar Foundation 2019). Despite being the fastest growing technology, only $21 \%$ of wind power jobs are occupied by women (IRENA 2020).

Figure 3 shows the share of women categorized by three broad job fields: science, technology, engineering and mathematics (STEM) jobs; non-STEM technical jobs; and administrative jobs (IRENA 2019a). The lowest share of women is found in STEM areas, such as facility operations and maintenance; equipment manufacturing, construction and installation project planning; and to a slightly higher extent, in non-STEM technical careers, such as finance, statistician and information technology. Furthermore, $45 \%$ of women's participation in the sector is concentrated in non-technical and administrative roles, such as human resources, marketing, knowledge, legal and business development.

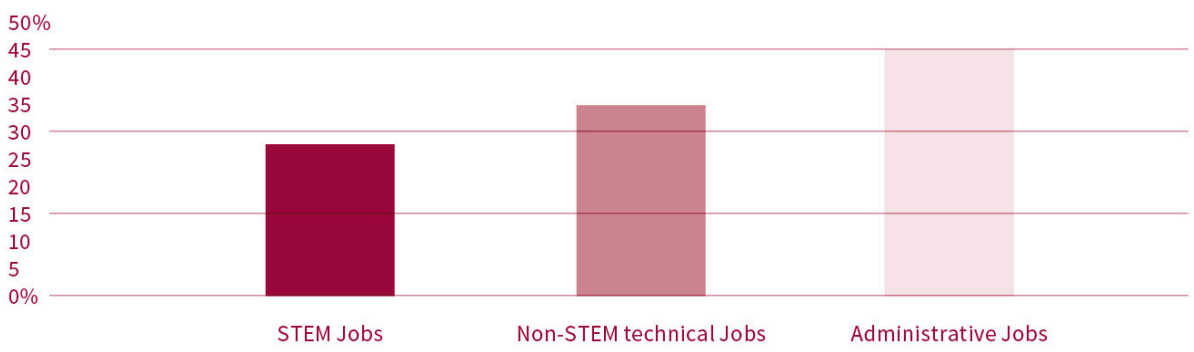

Figure 3. Job types of women in the renewable energy sector. Source: adapted from (C) IRENA (2019a); used with permission.

\subsection{Women's Persistent Underrepresentation in Specialized and Technical Functions}

Renewable energy jobs have largely inherited a pre-existing workforce with aptitudes and skills closely associated with STEM fields that supply the demand for 
skilled labor in the traditional energy sector. This means that reasons for the low involvement of women in the traditional energy sector also apply to renewables: (i) women are not interested in technical jobs, (ii) a low number of women graduates from STEM fields and (iii) the fact that the traditional scope of energy and utilities was perceived as technologically complex (See Section 4.3.1). These factors continue to affect the share of women in the renewables workforce throughout value chains and job functions.

Overall, women are underrepresented in finance, trading, technology, engineering and technical sales (Good Energy 2019), particularly in power and utility and infrastructure entities (Ernst and Young 2015). In the renewables sector, men outnumber women in key functions, namely, technical, managerial and policymaking positions. These significant imbalances are a worldwide reality, from within highly developed markets to communities where renewables are only just beginning to extend energy access (IRENA 2019a).

\subsection{Women's Barriers in Three Stages of Employment}

We outline below some recurring themes around the gender gap and challenges facing women in renewables jobs and employment in three stages of employment: (1) entry to employment, (2) job retention and (3) career advancement.

\subsubsection{Barriers to Entry: Gender Biases and Assumptions in Technical Jobs}

The gender gap in the renewables sector is often attributed to a small share of women in STEM education participation and gender differences in early schooling. Gender differences already exist in the early exposure to science and mathematics in favor of men. These differences become more apparent as the level of education increases, particularly from upper secondary education onwards (Chavatzia 2017). Based on data from the Trends in International Mathematics and Science Study (TIMSS) Advanced 2015, the majority of students taking courses in both mathematics and physics were boys (Chavatzia 2017).

In a UNESCO study of technical education for women in STEM in 120 countries, the assumptions and biases against women's abilities were also identified as factors that affect negatively their interest, willingness and confidence to engage in STEM subjects and subsequent job opportunities (Chavatzia 2017; Huyer 2015). Girls are often brought up to believe that aptitudes related to STEM subjects are not natural to women. There is some level of normalcy when referring to STEM and technical career path in favor of men. This is evident among our respondents, who stated, for instance, that "classic science is reserved for men's expectation". The energy 
sector is "rooted in the fact that women do not tend to gravitate towards studying STEM subjects". Normalizing words such as "normal", "typical", "traditionally", "belong to", "natural", "tend to", "suited" and "suitable" are used to describe the STEM and technical fields in men's favor and to disfavor of women. Women do not "really know that they can cope with technical and financing topics" or "have enough confidence themselves to be capable of doing STEM studies".

Women's disinterest in STEM subjects may no longer be a norm among younger generations, however. It has been documented that girls and boys shared similar levels of interest in STEM studies and careers initially in secondary education (GSRI 2012). Nowadays, women actually make up more than $50 \%$ of STEM university students in the 144 countries recently surveyed (IRENA 2019a). There is a growing number of women that have been trained in STEM subjects and have graduated in STEM and non-STEM technical fields in the last decade.

In the online survey conducted by IRENA, almost three-quarters (71\%) of respondents reported having at least a university degree in a science, technology, engineering or mathematics (STEM) subject. When asked to rank several specific barriers to entry according to their importance, they ranked the perception of gender roles and biases at the top, followed by cultural and social norms, rather than competences in STEM (IRENA 2019a). After schooling, women who have been trained in STEM continue to face biases related to their ability or competences to perform successfully in the energy sector jobs in the recruitment process. This bias persists even when women have the same or even superior STEM qualifications and work experience (Baruah 2016). Their credibility and ability to perform a technical and complex task are often questioned (Baruah 2016).

There is an absence of pull factors for girls and women to pursue STEM career in terms of social support network, role models and mentorship. Such absence leads to a culture of isolation in higher education and in entry-level recruitment (GSRI 2012).

\subsubsection{Prevailing Hiring Practices and Workplace Policies}

Today, $70 \%$ of women across the globe prefer to work a paid job rather than solely care for their families, a figure more closely aligned with $66 \%$ of their counterparts (ILO 2018b). Outdated recruitment attitudes may prejudice many women as they enter the industry, assuming, for example, that they will be working intermittently and in lower paid positions (Nelson and Kuriakose 2017).

Our survey and recent studies shine a light on unconscious biases challenging the "Myth of Merit" and the rationale for "cultural fit" in the recruitment and promotion within the energy sector. The perception of gender roles reinforced and filtered by 
cultural norms has permeated prevailing hiring practices and framing of a "cultural fit" as being of merit (Rivera 2015). The criteria for a "cultural fit" can translate to a hiring preference for the same gender, race, nationality, class or background as the dominant ones in the organization (GWNET 2020). This applies not only to staff placement but also to employment entry screening, i.e., apprenticeships and internships.

When asked if they think sex/gender has impacted their chance of getting a job or a promotion in the past, roughly $50 \%$ of our respondents used words indicating that they were unfairly evaluated compared to male colleagues, such as "Male managers using attribution bias during promotion selection" or "Some males [are] promoted much earlier than females" or simply "Men promote men". While more than $40 \%$ of our respondents said they were unsure or there was no influence, many of them are in junior roles or at the beginning of their career.

Recent studies reported a generational gap among the younger generation entering the energy sector. When diversity is seen at the entry to mid-career professionals, the decline in diversity is reported from above the mid-career and senior leadership positions (IRENA 2019a, 2020). One of our respondents, who is from a large company (250 employees or more) commented that, even when efforts are made to recruit more women into the company, "we have found that women plateau mid-career". This gender imbalance at the leadership level will further limit the opportunities of recruiting more women into the organization or providing enabling environments to support women's career progression into senior positions (GWNET 2020).

\subsubsection{Barriers to Career Retention Related to Familial Needs}

There are barriers related to the expected role of women in the family and their work-life balance which could affect their ability to stay in employment at the mid to senior management level. Difficulty in managing a work-life balance and lack of affordable childcare are common reasons for women's career interruption and eventual departure (ILO 2018b). One in three men still prefers their female partner to be the main family carer and responsible for unpaid housework rather than be in a paid job (Gallup and ILO 2017). Furthermore, 50\% of women graduates who indicated interest in pursuing STEM-related careers upon their graduation left employment or further training within the first decade after graduation due to various family and childbearing commitments (GSRI 2012). 
When asked whether the perception of women's role in the family (such as pregnancy and care giving) has affected or has been a factor in their career, the majority of our respondents $(63.30 \%)$ answered yes (Figure 4 ).

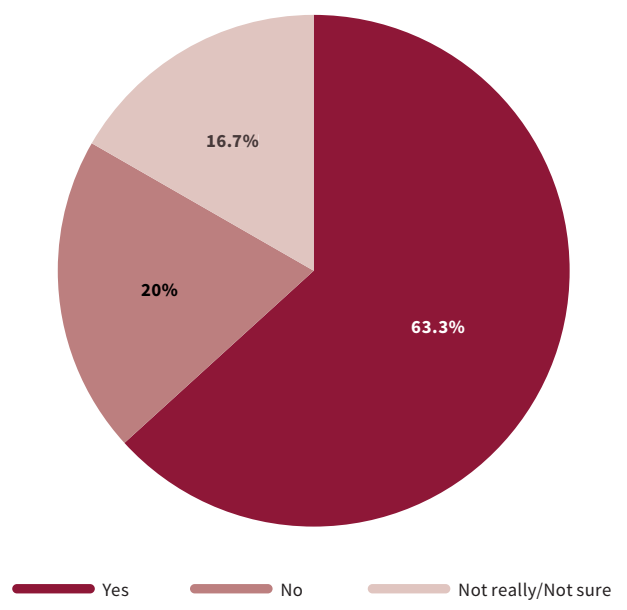

Figure 4. Respondents' opinion on whether the perception of women's role in the family (e.g., pregnancy and care giving) has impacted their career. Source: figure by authors.

Women often face the double burden of balancing work and family, particularly during their childbearing years. In Europe, 25\% of women picked the reason for care work as their reason to exit the workforce, versus 3\% for men (UN Women 2015). Our survey substantiates "the burden of childbearing" on women, where we have gathered comments such as "I delayed telling people that I was pregnant due to how it would affect my career prospects."; "[career advancement] it also affects my thinking and timing around when I would like to get pregnant. I would not announce to my boss that I am pregnant before I have secured my next promotion and pay"; "[for] the past 20 years I have been asked in job interviews when I planned to have children".

The gender gap after having a child is well documented (EIGE 2019; Kleven et al. 2018; Leturcq 2016). Women see a significant decrease in their number of hours worked compared to men after the birth of their first child (Kleven et al. 2018). In Denmark, where there exists generous parental leave for childcare, a significant drop (20\%) in salary is observed for women after the birth of the first child (Figure 5). 


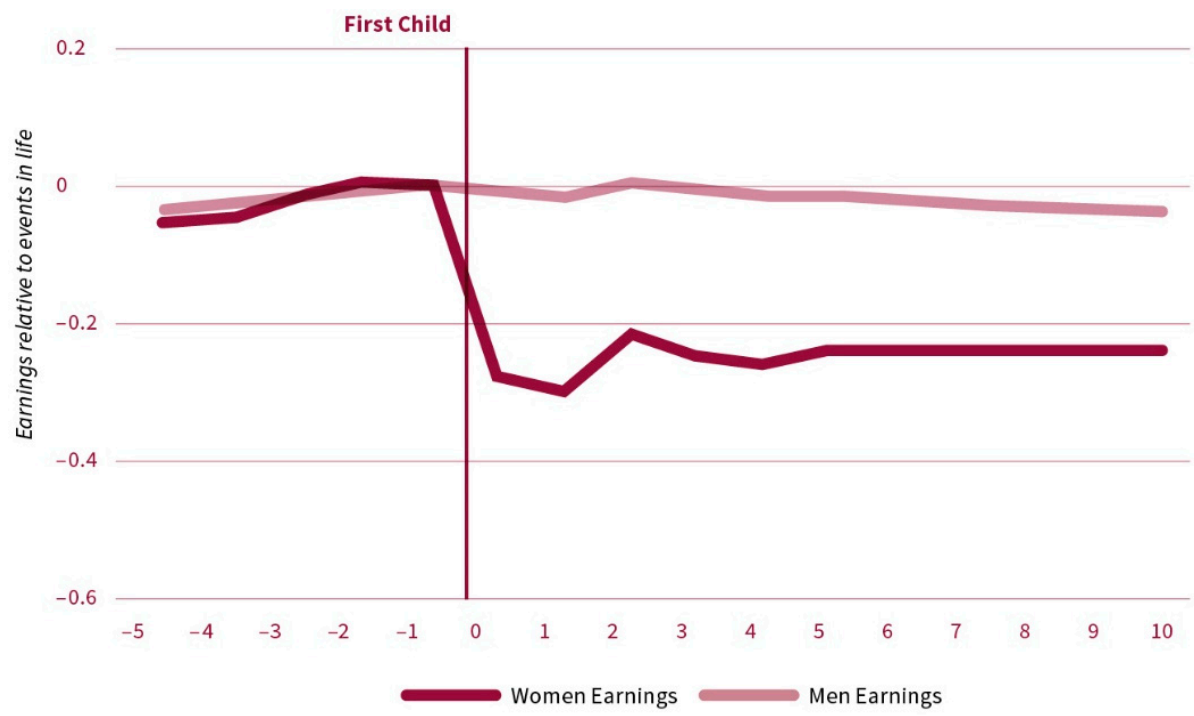

Figure 5. Earnings relative to women's' life events. Source: adapted from Kleven et al. 2018; used with permission.

Women's career breaks after having families are also related to a lack of flexibility in workplaces (Kleven et al. 2018; UN Women 2015; Leturcq 2016). Working mothers are $50 \%$ more likely than fathers to say that being a working parent inhibited their career advancement (Pew Research Centre 2013). Workplaces often require a strict working schedule and do not provide the flexibility for taking care of family demands. After the first childbirth, women tended to change jobs more often and were $10 \%$ more likely than men to seek government jobs for more flexibility. It was reported that, after the arrival of their second child, highly skilled women would reduce their working hours by an average of 5 hours, and 18 hours for lower-skilled women, who have less working flexibility and are more likely to work shift-work (Leturcq 2016). Childbearing can account for $80 \%$ of the wage gap overall.

Flexibility in the workplace is a recurring theme among our survey respondents: "Energy projects need a period of continuous time that no women can guarantee they won't pause in a project [due to pregnancy]", [There are fewer women in energy jobs because they do] not have the flexibility required by some roles", "Many roles [in the renewable energy sector] also involve significant travel and nights away from home". After maternity leave, "it's difficult to compete when they (male colleagues) 
work 5 days/week whilst I work 3 (days) ... however the expectations (in terms of job performance) are the same".

Support for working women could be the most efficient means to keep women in the labour force. In a study on $28 \mathrm{EU}$ countries, the affordability of childcare is by far the most often cited reason for unaccommodated needs (50\%), followed by a lack of available places (12\%), inconvenient opening hours (8\%) and distance $(5 \%)$ (EIGE 2019). Studies have shown that a provision of subsidized childcare services is positively correlated with the increased participation of women in the workforce (Olivetti and Petrongolo 2017).

There is an incentive to invest in the childcare infrastructure and services. An analysis of 7 OECD countries shows that investing only $2 \%$ of GDP in the care industry would increase women's employment from 3.3 to $8.2 \%$ and from 1.4 to $4 \%$ for men (ITUC 2016). Investing 2\% GDP in public care services would create up to four times as many jobs for women and could reduce the gender employment gap by $50 \%$ in some OECD countries (WBG 2016). Companies, too, can provide more support and flexibility without compromising performance, budgets and revenues.

\subsubsection{Barriers to Career Advancement}

While the ability for women to persevere and advance in their jobs is shaped by a number of factors, two issues are salient: (i) the absence of women leadership and social networks and (ii) the myth of leadership/what it takes to be a leader.

(i) Lack of Women Leaders, Mentors and Social Networks

Women's underrepresentation in the boards, senior management, policy making and governance of organizations is more acute in the energy sector compared to other sectors (e.g., Emelianova and Milhomem 2019; Deloitte 2019). A study from the International Energy Agency surveying 153 energy companies found that women held an average of $20 \%$ of seats on company boards across Finland, Sweden, Italy, Austria, Chile, Canada and Australia and occupied only $21 \%$ of the most prominent C-Suite titles (CEO, CFO, CIO, CMO and CHRO) among the top U.S. energy companies (Korn Ferry 2017). CEOs accounted for only $8 \%$ on average across the same countries (IEA 2019). The 4 companies with the largest numbers of female board members were Hydro-Quebec, 56\%; Engie, 56\%; General Motors, 50\%; Iren Spa, 46\%; and Statkraft, $44 \%$. Of 68 energy companies, $18 \%$ of the managerial positions are occupied by women (IEA 2019). Furthermore, 61\% of the largest energy companies under the Russell 3000 Index with head offices in the US have no female representation on their board of directors (GMI Ratings 2012). 
The situation in the public sector is no better. A 2015 study from the Environment and Gender Index led by the UN found that women occupy only $4 \%$ of the World Energy Council positions of which a majority of $18 \%$ are administrative positions (IUCN 2015). The International Energy Agency found that only $17 \%$ of energy ministerial positions were held by women between 1980 and 2017 (IEA 2019).

The absence of women leaders in the sector reinforces the existence of the "glass ceiling" (Morrison et al. 1987; Hymowitz and Schellhardt 1986). The metaphor has now been applied to a situation of both women and minorities in a business context where they believe that some forms of inequality exist that stop them from moving up in their careers.

According to a Pew Research study, $68 \%$ of Americans believe it is easier for men to achieve a top executive position. Both women and men admitted that women have to do more to prove themselves, while more women than men think this is the biggest obstacle to advancing their career (Pew Research Center 2019). In an IRENA study, where the existence of glass ceilings was identified as a key barrier to career advancement, men represent at least $75 \%$ of board members in nearly $50 \%$ of the participating private sector firms (IRENA 2019a).

Figure 6 shows that the majority of our respondents said they believe a glass ceiling exists in their workplace in one form or another (Figure 6). On a scale of 1 to 5 ( 5 being evident, and 1 being non-existent), the existence of a glass ceiling was identified as evidently (5) by nearly all women respondents who are currently in leadership/senior managerial positions.

One of our respondents from a medium-size company (50-249 employees) admitted "I was the first woman in management hired in the 35 years of the company's history ( 5 people informed me of this in my first week). No woman was promoted to management before". Another respondent from a company with over 250 employees elaborated why she believed the glass ceiling evidently exists in her company. "Our leadership team hires/promotes people of a similar perspective/view/nature. In fact, we had a discussion in recent weeks as part of the Diversity and Inclusion [D\&I] group, where it was argued that 'strategic hires' should be subject to the same D\&I practices that we are trying to implement across the company. There was push back by the leadership team. Also, we are battling for a D\&I performance metric to be set in all performance goals, again this has not been implemented for the third year running." 


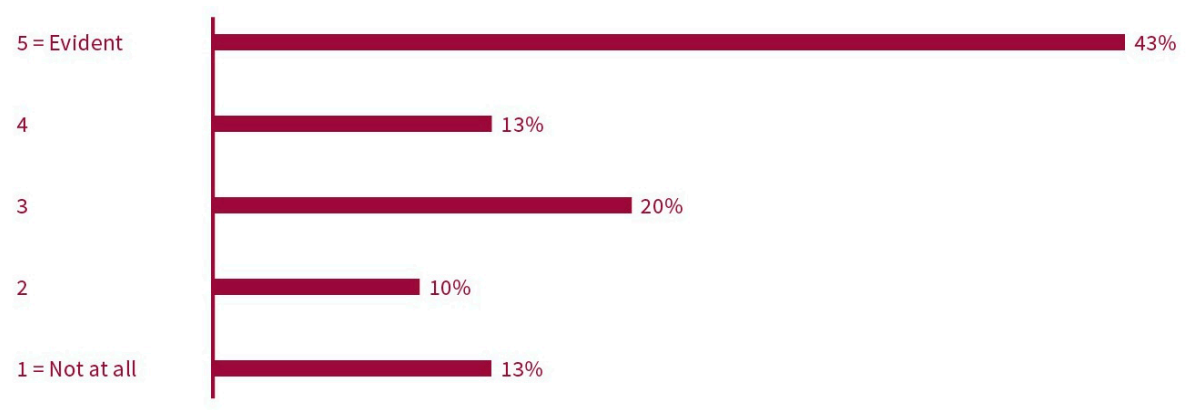

Figure 6. Perception of the existence of a "glass ceiling" among survey respondents. Source: figure by authors.

One reason for the "glass ceiling" is related to a doubt in women's abilities to fare well in technical and "powered" roles. Even when women want to thrive in the sector, one respondent reflected from her mid-career experience, "they could be sometimes relegated to more commercial administrative roles, which won't let them grow to the powered positions". Few women who manage to secure top positions can eventually find their leadership situation not tenable as they are less well connected compared to their male colleagues (IRENA 2019a).

Studies have shown that mentoring and networking activities designed for women are key to break through the glass ceiling and to remain in top positions (Richards 2017; Dow 2014). Multi-level mentorship and leadership programs are necessary in providing dynamic social support, including promoting gender awareness and building networks to support sustainable career development. Examples of successful mentoring programs include MetLife's 14-month leadership program training high-potential women in the company's leader pipeline. After 4 years of implementation, over $50 \%$ of MetLife's managers are now women. Another example is Sodexo's Mentoring Circle program which led to an increase in the representation of women by $10 \%$ at entry and manager level and doubled the C-Suite after 5 years of implementation (Montero 2019). Engie's ambitious gender targets and the progress made to reach them resulted in the company being one of the best FortuneGlobal 200 performers in having women in leadership at the board level $(62.5 \%)$ and in the management teams (30\%) for new operational entities (Engie 2018).

Strategic alliances can be formed with local and national diversity and inclusion independent groups to identify diverse candidates in leadership positions. Good examples include Women of Renewable Industries and Sustainable Energy (WRISE), 
the NAACP, Women in Energy Network and American Association of Blacks in Energy (AABE) (SEIA 2017). However, still too few are in place, particularly at the organizational level in energy companies. Numerous non-profit organizations have promoted mentorship programs, such as Women in Renewable Energy (WRE) and Global Women Network for the Energy Transition (GWNET).

(ii) The Myth of Leadership and Management Style

In the energy sector, leadership positions are traditionally reserved for experienced senior managers, technical directors and engineers often with high-level STEM qualifications-who are nearly all men. Knowledge and skills aside, one can also argue that the management level of an energy organization is limited to a familiar culture and personal traits validated by men already in the positions.

Studies have tried to explain the lack of women in leadership by associating it with acceptable leadership qualities and management style. Qualities considered as desirable and effective in negotiation and business settings, such as willingness to take risks in negotiating profitable deals, are often male-biased (Pew Research Center 2019). Positive traits more commonly found in women, such as being diplomatic, agreeable, or considerate, are considered as disadvantageous in a leadership position. While men are on average more than twice as likely to interrupt a woman speaking than a woman would a man (Handcock and Rubin 2015), women are often criticized for being "mean" or "unlikable" when they try to adopt those very same qualities their male counterparts accept as effective in business negotiation (Sandberg 2013).

Regardless of personality traits, women choose to bring to the table, data have indicated the multi-fold impact of women leadership on corporate performance, including environmental and economic returns. A study from EY showed that utilities with greater representation of women showed higher economic performance with the top 20 gender-diverse utilities outperforming the bottom 20 by $14.8 \%$ (McPherson 2019). Countries with a higher represented of women in parliament are more likely to lower carbon-dioxide emissions and set aside protected land areas (UNDP 2016). Companies are more likely to increase investment in renewable energy and to decrease carbon emissions throughout their value chain when there are more women on the board of directors (CRB 2012). Although the investment in female business owners is less than half of the investment in their male counterparts, women start-ups generate seventy-eight cents for every USD 1 invested versus thirty-one cents from their male counterparts (Abouzahr et al. 2018). Successes of women's leadership have been associated with increased revenue and improved economic performance through leveraging innovation, pro-social considerations and their relationships (Catalyst Information Center 2013). 
As women take on more leadership roles in many parts of the world (Pew Research Center 2019), a systematic analysis of women's contribution to energy transformation will be crucial for effecting impactful changes within the industry. Given that the issue of the gender gap is primarily an issue for the gender concerned, women are more likely to take initiatives regarding issues that relate to women, such as family policies, education and care (NG and Muntaner 2019). Progress towards gender equality will require the presence of women representing women's voice, particularly those in the position to bring about change within an organizational structure (e.g., Sandberg 2013).

\subsection{Gender Pay Gap}

The gender pay gap is a worldwide phenomenon with an estimated level at around $20-23 \%$. This means a woman earns 77-80 cents per USD 1 a man earns in comparable jobs (ILO 2018a; Gallup and ILO 2017). Based on data from 62 countries reported on the SDG progress in 2019, the median hourly gender pay gap is at $12 \%$ (UN 2019). The pay gap exists in low-income countries as well as in countries with high per-capita levels, with some of them with the highest gender wage gaps in the world. The gender pay gap is self-reported by Ireland, Mexico and Switzerland as their main challenge to achieving SDG 5 (UN DESA 2018b).

Despite higher average wages in the energy industry compared to other sectors among OECD countries, women occupy the lower wage class across occupational categories (OECD 2017; Antoni et al. 2015 German data). The gap is widened in managerial and professional occupations (including the bonus gap), in craft and related trades and in plant and machine operation and assembling (Good Energy 2019). Specific examples in renewable energy include EDF Energy the recompenses men $31.9 \%$ on average more than women, Innogy Renewables $22 \%$, and SSE $22 \%$. Consultancies active in the sector reported the following: Amec Foster Wheeler Environment and Infrastructure UK offers wages to men that are 22\% higher than those of women, and Wood Group 16.6\% (A Word About Wind 2018).

IRENA identified the multifaceted causes of the gender pay gap in the renewable energy sector as follows: (1) women's larger concentration in lower-paying, non-technical and administrative jobs and junior positions; (2) women's comparatively weaker negotiating positions; (3) their tendencies to compromise work for family obligations, such as parenting and caregiving; (4) the attitudes and values of employers, and (5) pay discrimination (IRENA 2019a).

Progress on closing the gender pay gap has already been made in Iceland with public utility Reykjavik Energy, who consciously increased its portion of women in 
management to $49 \%$ and in Australia, where the Australian Institute of company directors provided a deadline to increase boards made up of women by $30 \%$ within 3 years to ASX200 companies. This induced a significant positive change, such as with Energy Australia, where women now occupy half of the 10 seats of board members after a careful plan implemented by the company (HRM 2019).

\subsection{Lack of Awareness on the Needs and Benefits of Gender Diversity}

Among the contributing factors to a gender gap in the energy sector is related to a lack of gender awareness and awareness on what gender diversity could bring to the table. On an interpersonal level, this lack of awareness can create unpleasant working environments for women, for example, a culture of isolation and loneliness. Women working as the "only" woman in the team have reported significantly worse work experiences than women who work with other women (McKinsey and Company 2018). Almost two-thirds of women receive regular microaggressions in business settings. Their judgment in their own area of expertise is often questioned and they feel under constant pressure to provide proof of their competence compared to their male colleagues (McKinsey and Company 2018).

An awareness of gender issues is an issue for all men and women stakeholders and cannot be assumed to happen naturally in an organization, let alone in the entire industry. Perceptions of inequity are further shaped by gender awareness and bias, and women are often made more aware than men. In the IRENA study, for example, $60 \%$ of men believe that women and men are paid equally, compared to $29 \%$ of women responding (IRENA 2019a). While it is understandable that gender awareness in the renewables sector is driven by women (IRENA 2019a), efforts should be made to involve men. Women and men interviewees in the energy sector who had not been exposed to discriminatory issues themselves often did not know how to identify and recognize barriers and enablers in the context of their employment and career progression (GWNET 2020).

To raise gender awareness with buy-ins in an organization is to recognize gender as a factor in creating a competitive advantage, contributing to the bottom line and serving as a force for economic growth (e.g., World Bank 2006; Goldman Sachs 2010; MGI 2015). Research indicates that having gender diversity in a company is linked with greater creativity, innovation and openness. In fact, certain competencies that women display more often than men, such as higher cognitive, social, emotional and skills, are expected to be highly valuable to enterprises (McKinsey and Company 2018). 
Investing in gender-inclusive recruitment processes and policies can be justified through a compelling business case or a cost-benefit analysis. By investing in a system for the recruitment and advancement of the best person for the job without the influence of gender bias, the benefits will likely outweigh the costs. In the ILO report on a business case for gender diversity, $57 \%$ of companies surveyed globally agreed that gender diversity initiatives improve business outcomes (ILO 2019). The challenge might lie in ensuring buy-in within the organizational structure through quantifiable measures indicating projected benefits of diversity, such as improvements in profitability and productivity, company image and reputation, ability to attract and retain talent, creativity, innovation and ability to understand consumer needs and interests (ILO 2019).

\subsection{Lack of Data and Measurement}

Gender gaps in the renewable energy workforce and supply chain are less likely to be taken seriously, unless there are clear data to support necessary adjustments. There is not currently a wide range of gender-disaggregated data available for the whole energy sector, let alone for subsector-specific studies. In most employment data, specific information on the participation of both sexes is not generally included (World Bank 2013). In many countries, adding a gender metric to employment data and constituent subsectors would be an additional burden.

Restricted data on the level and nature of women's employment pose a multi-fold challenge to addressing gender diversity in the energy transition (Baruah 2016). Short of having gender as a data point in the collection of information about the renewables workforce and its supply chain, analyses of the energy transition will be incomplete or misleading in multiple ways. For example, without gender-disaggregated data, current employment practices will continue to limit opportunities for women (e.g., Rivera 2015). When gender-sensitive methodologies for data collection and research design are not applied, scientific progress will be developed without reference to women's needs. Overall, when gender biases and disparities are perceived as business as usual, policies and initiatives on the energy transition are less likely to integrate a serious consideration of gender.

In recent years, non-governmental organizations (NGOs) and the private sector have increasingly explored the gender issue in the energy sector of developing countries (World Bank 2013). Some renewable energy companies are taking the lead in providing opportunities for women. Statkraft, a generator of renewable energy, has provided employment opportunities specifically for women in Peru and set the clear targets of developing gender diversity to have $40 \%$ top management positions filled by 
women (Statkraft 2015, 2018). Fortum, a renewable energy supplier, has been elected among top 100 companies for gender equality (Equileap 2019). Siemens Gamesa, a wind turbine manufacturer, is part of the United Nations initiative Women's Empowerment Principles: "a community of companies committed to making a difference for women in the workplace, marketplace and community, accelerating the global momentum toward gender equality in the workplace" (Siemens Gamesa 2020). These initiatives are mainly undertaken by a few relatively large publicly listed companies, which are perhaps more under the scrutiny of the public eye and incentivized by the likes of Bloomberg (Bloomberg Gender-Equality Index (GEI)).

\section{Conclusions and Recommendations}

We attempted, in this study, to demonstrate that gender equity and its various approximations (equality, diversity, inclusion, parity) are not simply an ethical or fairness issue but an economic issue. Gender diversity is compatible with economic growth when the deficits and benefits of gender parity influence the agenda and outcome of inclusive growth.

It is no secret that women's increased workforce participation in the last decade is a key contributor to economic growth. Closing the employment gap would further increase a significant positive impact on the development of economies and would increase GDP in the Eurozone by $13 \%$, for example. Once employment parity is in place, global GDP should grow to USD 12 trillion, resulting in a $26 \%$ increase in global annual GDP or USD 28 trillion by 2025 (MGI 2015). The lack thereof has tremendous economic costs and, thus, underlines the need for diversity. Women's limited access to employment in certain regions (such as in Asia and the Pacific) has been reported to cause a loss equivalent to USD 42 to 47 billion in GDP each year (WEF 2015).

A gender-inclusive energy transition will require, at the very least, indicators which measure progress beyond GDP towards addressing inequalities and tackling barriers which result in those inequalities. This will require an alternative economic theory which embraces equality and diversity as an integral, if not essential, part of economic growth. Theories such as "gender equality as smart economic", one which constructs women as entrepreneurs and a fundamental source of future business growth (World Bank 2006; Goldman Sachs 2010), might be worth exploring for the energy transition. As the renewables sector sees a growing share of women entering through trade, financial and business services, a framework which can broadly integrate and empower them to compete effectively in the sector's workforce is of great urgency. 
It is unfortunate to find key targets and indicators under SDG 8, except for Target 8.5 , fundamentally at odds with gender equality. As the rationale for pursuing diversity and inclusion is not reflected in SDG 8 main targets, there is no incentive at the national level to ensure that women are accounted for in the energy transition. It is unclear how women can be empowered to participate effectively and grow more innovative and competitive in the renewables workforce and its economy. This is a missed opportunity.

It is crucial, in our view, that gender diversity be taken seriously at the management level among energy companies. Given that the employment gap between men and women across the globe is estimated to be around $27 \%$ and in Europe at $12 \%$, there is much to overcome for the renewables sector to take a leap for change. As the renewables workforce is portraying itself as young, technologically savvy and progressive, the sector will be pressured to close the gender gap. Given that gender parity will likely not be realized within the next 100 years (WEF 2019), the industry should be proactive at the forefront of bridging a gender gap as much as it is seeking more sustainable energy sources as an alternative to fossil fuel (Eurostat 2017).

The most important first steps involve collecting gender information and setting concrete gender targets and measurements. Companies should invest in value creation and promote gender equality as a business/economic issue and recognize the return on investment (ROI) benefit for companies to take gender targets seriously. Gender indicators could be part of a financial target for companies. At the organizational level, the awareness of the social and cultural benefits of gender diversity and the consequences of exclusion should be incorporated into companies' key performance indicators (KPIs), involve both women and men and be integrated and measured wherever possible. Institutional policies should be put in place to recruit female talents, promote an inclusive team culture, and tackle gender biases in order to encourage women to stay in their jobs. There can be no inclusive growth if workforces lack diversity.

Author Contributions: Conceptualization, S.V. and A.N.; methodology, S.V. and A.N.; validation, S.V. and A.N.; formal analysis, S.V. and A.N.; investigation, S.V. and A.N.; resources, S.V. and A.N.; data curation, S.V. and A.N.; writing-original draft preparation, S.V. and A.N.; writing - review and editing, S.V. and A.N.; visualization, A.N.; supervision, S.V. and A.N.; project administration, S.V. All authors have read and agreed to the published version of the manuscript.

Funding: This research received no external funding.

Acknowledgments: The authors express special gratitude to their network partners, namely, Global Wind Energy Council's Women and Wind Program and its EU and Asian Network, the Association of Dutch Suppliers in the Offshore Energy Industry (Netherlands/EU), POWERful 
Women (UK/EU), Turkish Women's Network in Renewable Energy (Turkey), Women in Clean Energy (WICE), Women in Renewable Industries and Sustainable Energy (WRISE, USA), Women in Energy (AUS) and Solar Wonder Women (UK/EU) for their support in distributing our semi-structured questionnaires within their networks.

Conflicts of Interest: The authors declare no conflict of interest.

\section{References}

A Word About Wind. 2018. The Blog: Wind Energy Market Analysis. How Can Renewable Energy Businesses Close the Gender Pay Gap? Available online: http://membership. awordaboutwind.com/blog/is-there-a-pay-gap-in-renewable-energy (accessed on 30 January 2020).

Abouzahr, Katie, Frances Brooks Taplett, Matt Krentz, and John Harthorne. 2018. Why Women-Owned Startups Are a Better Bet. Boston: BCG.

Allen, Elizabeth, Hannah Lyons, and Jennie C. Stephens. 2019. Women's leadership in renewable transformation, energy justice and energy democracy: Redistributing power. Energy Research \& Social Science 57: 101233.

Allison, Juliann Emmons, Kirin McCrory, and Ian Oxnevad. 2019. Closing the renewable energy gender gap in the United States and Canada: The role of women's professional networking. Energy Research \& Social Science 55, pp. 35-45.

Antoni, Manfred, Markus Janser, and Florian Lehme. 2015. The hidden winners of renewable energy promotion: Insights into sector-specific wage differentials. Energy Policy 86, pp. 595-613. [CrossRef]

Baruah, Bipasha. 2016. Renewable inequity? Women's employment in clean energy in industrialized, emerging and developing economies. Natural Resources Forum 41, pp. 18-29. [CrossRef]

Berkhout, Frans, Peter Marcotullio, and Tatsuya Hanaoka. 2012. Understanding energy transitions. Sustainability Science 7, pp. 109-11. [CrossRef]

Boniol, Mathieu, Michelle McIsaac, Lihui Xu, Tana Wuliji, Khassoum Diallo, and Jim Campbell. 2019. Gender Equity in the Health Workforce: Analysis of 104 Countries. Health Workforce Working Paper 1. Geneva, Switzerland: WHO.

Burke, Matthew J., and Jennie C. Stephens. 2018. Political Power and Renewable Energy Futures: A Critical Review. Energy Research \& Social Science 35, pp. 78-93.

Carlsson-Kanyama, Annika, and Anna-Lisa Lindén. 2007. Energy efficiency in residences -Challenges for women and men in the north. Energy Policy 35, pp. 2163-72. [CrossRef]

Catalyst Information Center. 2013. Why Diversity Matters. Toronto: Catalyst Information Center. Columbia Center on Sustainable Investment, Equitable Origin, Business \& Human Rights Resource Centre, and The United Nations Sustainable Development Solutions Network (SDSN). 2019. Mapping the Renewable Energy Sector to the Sustainable Development Goals: An Atlas. New York, Washington, DC and London: UNDP/IFC/IPIECA. 
Chancel, Lucas, Géraldine Thiry, and Damien Demailly. 2014. Beyond-GDP Indicators: To What End? Lessons Learnt from Six National Experiences. IDDRI Study. $\mathrm{N}^{\circ} 04 / 14$, September. Paris: The Institute for Sustainable Development and International Relations.

Chavatzia, Theophania. 2017. Cracking the Code: Girls' and Women's Education in Science, Technology, Engineering and Mathematics (STEM). Paris: UNESCO.

Chien, Taichen, and Jin-Li Hu. 2008. Renewable energy: An efficient mechanism to improve GDP. Energy Policy 8, pp. 3045-52. [CrossRef]

Clancy, Joy. 2009. Late Developers: Gender Mainstreaming in the Energy Sector. Twente: University of Twente.

Clancy, Joy S., and Mariëlle Feenstra. 2006. How to Engender Energy Policy. The Hague: ENERGIA.

Clancy, Joy, and Beatrice Khamati-Njenga. 2003. Concepts and Issues in Gender and Energy. The Hague: ENERGIA.

Coscieme, Luca, Lars F. Mortensen, Sharolyn Anderson, James Ward, Ian Donohue, and Paul C. Sutton. 2020. Going beyond Gross Domestic Product as an indicator to bring coherence to the Sustainable Development Goals. Journal of Cleaner Production 248: 119232. [CrossRef]

Center for Responsible Business (CRB). 2012. Women Create a Sustainable Future. Berkeley: Haas School of Business, University of California Berkeley.

Deloitte Global Center for Corporate Governance. 2019. Women in the Boardroom: A Global Perspective, 6th ed. New York: Deloitte Global Center for Corporate Governance.

Dow, Roselynn S. 2014. Leadership responsibility in mentoring organization newcomers. Journal of Management Policy and Practice 15, pp. 104-12.

European Institute for Gender Equality (EIGE). 2019. Gender Equality Index 2019. Work Life Balance. Vilnius: EIGE.

Elliott, David. 1997. Energy, Society, and Environment: Technology for a Sustainable Future. East Sussex: Psychology Press.

Emelianova, Olga, and Christina Milhomem. 2019. Women on Boards 2019 Progress Report. New York: MSCI.

ENERGIA. 2009. Biofuels for Sustainable Rural Development and Empowerment of Women: Cases Studies from Africa and Asia. The Hague: ENERGIA.

Engie. 2018. Professional and Gender Equality. Available online: https://www.engie.com/en/ commitments/professional-and-gender-equality (accessed on 25 January 2020).

Equileap. 2019. Gender Equality, Global Report and Ranking. Available online: https: //equileap.org/2019-global-report/ (accessed on 30 January 2020).

Ernst and Young. 2015. Women in Power and Utilities Index 2015. Available online: http://www.ey.com/Publication/vwLUAssets/EY-women-in-power-and-utilities-index2015/\$FILE/EY-women-in-power-and-utilities-index-2015.pdf (accessed on 27 January 2020). 
European Union. 2002. Directive on Renewable Energy. Indicative Targets. Brussels: European Union.

Eurostat. 2017. Gender Statistics. Available online: https://ec.europa.eu/eurostat/statisticsexplained/index.php/Gender_statistics\#Labour_market (accessed on 30 January 2020).

Farhar, Barbara. 1998. Gender and renewable energy: Policy, analysis, and market implications. Renewable Energy 15, pp. 230-39. [CrossRef]

Fioramonti, Lorenzo. 2013. Gross Domestic Problem: The Politics Behind the World's Most Powerful Number. London: Zed Book, 208p, ISBN 9781780322728.

Fioramonti, Lorenzo. 2017. The World after GDP: Economics, Politics and International Relations in the Post-Growth Era. Cambridge and Malden: Polity Press.

Fioramonti, Lorenzo, Luca Coscieme, and Lars F. Mortensen. 2019. From gross domestic product to wellbeing: How alternative indicators can help connect the new economy with the Sustainable Development Goals. The Anthropocene Review 6: 207e222. [CrossRef]

Fri, Robert, and Maxine Savitz. 2014. Rethinking energy innovation and social science. Energy Research E Social Science 1, pp. 183-87.

Gallup, Inc., and The International Labour Organization. 2017. Towards a Better Future for Women and Work: Voices of Women and Men. Geneva and Washington: ILO.

Giannetti, Biagio, Feni Agostinho, Cecília Almeida, and Donald Huisingh. 2015. A review of limitations of GDP and alternative indices to monitor human well-being and to manage eco-system functionality to ensure sustainable societal development. Journal of Cleaner Production 87, pp. 11-25. [CrossRef]

GMI Ratings. 2012. GMI Ratings Releases Research Findings on Gender Diversity on U.S. Boards of Directors. Available online: http://www3.gmiratings.com/home/2012/07/july31-2012-press-release-2 (accessed on 4 September 2015).

Goldman Sachs. 2010. Womenomics 3.0: The Time Is Now. New York: Goldman Sachs Group.

Good Energy. 2019. Gender Pay Report 2019. Available online: https://www.goodenergy.co. uk/media/18331/good-energy-gender-report-2019.pdf (accessed on 31 January 2020).

Girl Scout Research Institute (GSRI). 2012. Generation STEM: What Girls Say About Science, Technology, Engineering and Math. New York: GSRI.

Global Women's Network for the Energy Transition (GWNET). 2020. Strategies to Foster Women's Talent for Transformational Change: Technical Working Document. Abu Dhabi: GWNET.

Handcock, Adrienne, and Benjamin Rubin. 2015. Influence of communication partner's gender on language. Journal of Language and Social Psychology 1, pp. 46-64. [CrossRef]

HRM. 2019. What Does Closing the Gender Pay Gap in a Few Weeks Looks Like? Available online: https://www.hrmonline.com.au/gender-diversity/closing-gender-paygap/ (accessed on 31 May 2020).

Huyer, Sophia. 2015. Is the Gender Gap Narrowing in Science and Engineering? In UNESCO Global Science Report 2015. Paris: UNESCO. 
Hymowitz, Carol, and Timothy D. Schellhardt. 1986. The Glass Ceiling: Why Women Can't Seem to Break the Invisible Barrier That Blocks Them from the Top Jobs. The Wall Street Journal 24 p. 1.

International Energy Agency (IEA). 2019. Clean Energy Ministerial. Status Report on Gender Equality in the Gender Sector. Available online: http:/www.cleanenergyministerial.org/sites/default/files/ 2019-06/Status\%20Report\%20on\%20Gender\%20Equality\%20in\%20the\%20Energy \%20Sector_ 0.pdf (accessed on 27 January 2020).

International Labour Organization (ILO). 2018a. Global Wage Report 2018/19: What Lies Behind Gender Pay Gaps. Geneva: International Labour Office.

International Labour Organization (ILO). 2018b. The Gender Gap in Employment: What's Holding Women Back? Geneva: ILO.

International Labour Organization (ILO). 2019. Women in business and management: The business case for change. In The Business Case for Change. Geneva: Bureau for Employers' Activities (ACT/EMP).

ILO NORMLEX. 2020. International Labour Organisation. 2020. Information System on International Labour Standards. Available online: https:/www.ilo.org/dyn/normlex/en/ f?p=1000:12001:::NO::: (accessed on 31 January 2020).

ILOSTAT and World Bank. 2020. International Labour Organization, ILOSTAT Database. 2020. In Labor Force Participation Rate, Female. (Compared with Labor Force, Female (\% of Total Labor Force). Geneva: International Labour Office.

International Renewable Energy Agency (IRENA). 2014. REmap 2030: A Renewable Energy Roadmap. Abu Dhabi: IRENA.

International Renewable Energy Agency (IRENA). 2016. Renewable Energy Benefits: Measuring the Economics. Abu Dhabi: IRENA.

International Renewable Energy Agency (IRENA). 2019a. Renewable Energy: A Gender Perspective. Abu Dhabi: IRENA, pp. 3, 19.

International Renewable Energy Agency (IRENA). 2019b. Renewable Energy and Jobs-Annual Review 2019. Abu Dhabi: IRENA.

International Renewable Energy Agency (IRENA). 2020. Wind Energy: A Gender Perspective. Abu Dhabi: IRENA.

International Trade Union Confederation (ITUC). 2016. Investing in the Care Economy: A Pathway to Growth. Available online: https://www.ituc-csi.org/investing-in-the-careeconomy-a (accessed on 31 January 2020).

International Union for Conservation of Nature (IUCN). 2015. Unleashing the Power of Women in the Renewable Energy Sector. Available online: https://genderandenvironment.org/ 2015/10/unleashing-the-power-of-women-in-the-renewable-energy-sector/ (accessed on 30 January 2020).

Jacobson, Mark Z., and Mark A. Delucchi. 2009. A Path to Sustainable Energy by 2030. Scientific American 301: 58-65. [CrossRef] [PubMed] 
Kleven, Henrik, Camille Landais, and Jakob Egholt Søgaard. 2018. Children and Gender Inequality. Evidence from Denmark. Cambridge, MA: National Bureau of Economic Research.

Korn Ferry. 2017. Korn Ferry Analysis of Largest U.S. Companies Shows Percentage of Women in Most C-Suite Roles Dramatically Lagging Male Counterparts. Press Release, December 18.

Lallement, Dominique. 2013. Infrastructure and gender equality. Chapter 9. In Handbook of Research on Gender and Economic Life. Edited by Deborah M. Figart and Tonia L. Warnecke. Cheltenham: Edward Elgar Publishing, p. 592.

Le Blanc, David. 2015. Towards integration at last? The sustainable development goals as a network of targets. Sustainable Development 23, pp. 176-87. [CrossRef]

Leturcq, Marion. 2016. The Gender Gap and Childcare. Institut National D'études Démographiques. VOX. Available online: https://voxeu.org/content/gender-gap-andchildcare (accessed on 31 January 2020).

Lucas, Hugo, Stephanie Pinnington, and Luisa F. Cabeza. 2018. Education and training gaps in the renewable energy sector. Solar Energy 173, pp. 449-55. [CrossRef]

Madgavkar, Anu, James Manyika, Mekala Krishnan, Kweilin Ellingrud, Lareina Yee, Jonathan Woetzel, Michael Chui, Vivian Hunt, and Sruti Balakrishnan. 2019. The Future of Women at Work: Transitions in the Age of Automation. New York: McKinsey Global Institute.

McKinsey and Company. 2018. Women in the Workplace 2018. Washington: McKinsey and Company.

McPherson, Sharron L. 2019. Women Could be the Game Changers in SA's Energy Crisis. Cape Town: Graduate School of Business University of Cape Town.

McKinsey Global Institute (MGI). 2015. The Power of Parity: How Advancing Women's Equality Can Add \$12 Trillion to Global Growth. Washington: McKinsey and Company.

Montero, Diana. 2019. 5 Keys to Implementing Successful Women's Leadership Programs. Stratx-exl. Available online: https://www.stratx-exl.com/industry-insights/implementingsuccessful-womens-lead (accessed on 28 March 2020).

Morrison, Ann M., Randall P. White, and Ellen Van Velsor. 1987. Breaking the Glass Ceiling. Reading: Addison-Wesley.

Nagel, Joane. 2015. Gender and Climate Change: Impacts, Science, Policy. New York: Routledge. Nelson, Sibyl, and Anne T. Kuriakose. 2017. Gender and Renewable Energy: Entry Points for Women's Livelihoods and Employment. Washington, DC: Climate Investment Funds.

NG, Edwin, and Carles Muntaner. 2019. The More Women in Government, the Healthier a Population. Available online: http://theconversation.com/the-more-women-ingovernment-the-healthier-a-population-107075 (accessed on 30 January 2020).

Odum, Howard T. 1971. Environment, Power, and Society. New York: Wiley Interscience.

OECD. 2017. The Pursuit of Gender Equality: An Uphill Battle. Paris: OECD Publishing. 
Olivetti, Claudia, and Barbara Petrongolo. 2017. The Economic Consequences of Family Policies: Lessons from a Century of Legislation in High-Income Countries. Journal of Economic Perspectives 31, pp. 205-30. [CrossRef]

Parikh, Jyoti. 1995. Gender issues in energy policy. Energy Policy 23, pp. 745-54. [CrossRef] Pearl-Martinez, Rebecca, and Jennie C. Stephens. 2017. Toward a gender diverse workforce in the renewable energy transition. Sustainability: Science, Practice and Policy 12, pp. 8-15. [CrossRef]

Pew Research Centre. 2013. On Pay Gap, Millennial Women Near Parity—For Now. Washington, DC: Pew Research Center.

Pew Research Center. 2019. The Data on Women Leaders. Available online: https://www. pewsocialtrends.org/fact-sheet/the-data-on-women-leaders/ (accessed on 20 February 2020).

Price Waterhouse Coopers (PwC). 2015. Igniting Change: Building the Pipeline of Female Leaders in Energy. London: PwC.

Rai, Shirin M., Benjamin D. Brown, and Kanchana N. Ruwanpura. 2019. SDG 8: Decent work and economic growth-A gendered analysis. World Development 113, pp. 368-80. [CrossRef]

Räty, Riitta, and Annika Carlsson-Kanyama. 2010. Energy consumption by gender in some European countries. Energy Policy 38, pp. 646-49. [CrossRef]

Richards, Heidi. 2017. Success Factors of Women in Leadership Roles and Breaking through the Glass Ceiling: A Phenomenological Qualitative Study. Ph.D. dissertation, Nova Southeastern University, Fort Lauderdale, FL, USA.

Rivera, Lauren. 2015. Guess Who Doesn't Fit In at Work. New York Times. May 31. Available online: http://www.nytimes.com/2015/05/31/opinion/sunday/guess-who-doesnt-fit-inatwork.html?_r=0 (accessed on 20 February 2020).

Runyan, Anne Sisson. 2016. Gender in Global Restructuring. In Handbook on Gender in World Politics. Edited by Jill Steans and Daniela Tepe. Cheltenham: Edward Elgar Publishing, pp. 354-61.

Sandberg, Sheryl. 2013. Lean in, Women, Work and the Will to Lead, 1st ed. New York: Knopf Doubleday Publishing.

Solar Energy Industry Association (SEIA). 2017. Diversity Best Practices Guide for the Solar Industry. Washington, DC: SEIA.

Siemens Gamesa. 2020. The Power of Diversity in Wind Energy, a World of Opportunities. Available online: https://www.siemensgamesa.com/en-int/sustainability/diversity (accessed on 25 April 2020).

Solar Foundation. 2019. National Solar Jobs, Census 2018. Washington: Solar Foundation.

Spaiser, Viktoria, Shyam Ranganathan, Ranjula Bali Swain, and David J. T. Sumpter. 2017. The sustainable development oxymoron: Quantifying and modelling the incompatibility of 
sustainable development goals. International Journal of Sustainable Development $\mathcal{E}$ World Ecology 24, pp. 457-70.

Statista. 2015. Energy Industry: Share of GDP by Country. Available online: https://www. statista.com/statistics/217556/percentage-of-gdp-from-energy-in-selected-countries/ (accessed on 15 March 2020).

Statkraft. 2015. Weaving Their Way to a Better Life. Available online: https://stories.statkraft. com/Archive/2015/weaving-their-way-to-a-better-life/ (accessed on 20 March 2020).

Statkraft. 2018. Annual Report 2018. Available online: https://www.statkraft.com/globalassets/ 1-statkraft-public/05-investor-relations/4-reports-and-presentations/2018/annualreport-2018/2018-annual-report-statkraft-as.pdf (accessed on 20 March 2020).

Stephens, Jennie C. 2019. Energy Democracy: Redistributing Power to the People through Renewable Transformation. Journal Environment: Science and Policy for Sustainable Development 61, pp. 4-13. [CrossRef]

Strietska-Ilina, Olga, Christine Hofmann, Mercedes Durán Haro, and Shinyoung Jeon. 2011. Skills for Green Jobs: A Global View. Synthesis Report Based on 21 Country Studies. Geneva: International Labour Office.

United States Bureau of Labour Statistics. 2017. Labor Force Statistics from the Current Population Survey, Employed Persons by Detailed Industry, Sex, Race, and Hispanic or Latino Ethnicity; Washington, DC: Bureau of Labour Statistics.

United Nations (UN). 2019. Report of the Secretary General on SDG progress 2019: Special Edition. New York: United Nations.

UN Department of Economic and Social Affairs (UN DESA). 2018a. Analysis of the Voluntary National Reviews Relating to Sustainable Development Goal 7 2018: Ensuring Access to Affordable, Reliable, Sustainable and Modern Energy for All. New York: United Nations.

UN Department of Economic and Social Affairs (UN DESA). 2018b. Synthesis of Voluntary National Reviews 2018. New York: United Nations.

United Nations General Assembly (UN GA). 2015. Resolution adopted by the General Assembly on 25 September 2015. In Transforming Our World: The 2030 Agenda for Sustainable Development. U.N. Doc. A/RES/70/1. para. 74. New York: UN GA.

UN Women. 2015. United Nations Entity for Gender Equality and the Empowerment of Women. Progress of The World's Women 2015-2016. Available online: http://progress. unwomen.org/en/2015/ (accessed on 20 February 2020).

United Nations Development Programme (UNDP). 2016. Gender and Climate Change. New York: UNDP.

United Nations Industrial Development Organization (UNIDO), and Global Green Growth Institute (GGGI). 2015. Global Green Growth: Clean Energy Industry Investments and Expanding Job Opportunities, Vol. I: Overall Findings, Vienna, Austria and Seoul, South Korea. Vienna and Seoul: UNIDO and GGGI. 
Warr, Benjamin S., and Robert U. Ayres. 2009. Increase Supplies, Increase Efficiency: Evidence of Causality Between the Quantity and quality of Energy Consumption and Economic Growth. Faculty Research Working Paper No. 2009/22/EPS/ISIC. Fontainebleau: INSEAD.

Women's Budget Group (WBG). 2016. Investing in the Care Economy to Boost Employment and Gender Equality. London: Women's Budget Group.

World Energy Council (WEC). 1994. New and Renewable Energy Resources: A Guide to the Future. London: Kogan Page.

World Economic Forum (WEF). 2012. New Energy Architecture Enabling an Effective Transition. Geneva: WEF.

World Economic Forum (WEF). 2015. The Global Gender Gap Report 2015. Insight Report. Geneva: WEF.

World Economic Forum (WEF). 2017. The Global Gender Gap Report. Geneva: WEF.

World Economic Forum (WEF). 2019. The Global Gender Gap Report 2020. Geneva: WEF.

Wei, Max, Shana Patadia, and Daniel M. Kammen. 2010. Putting renewables and energy efficiency to work: How many jobs can the clean energy industry generate in the US? Energy Policy 38, pp. 919-31. [CrossRef]

Weitz, Nina, Henrik Carlsen, Måns Nilsson, and Kristian Skånberg. 2018. Towards systemic and contextual priority setting for implementing the 2030 Agenda. Sustainability Science 13, pp. 531-48. [CrossRef]

World Bank. 2006. Gender Equality as Smart Economics: A World Bank Group Gender Action Plan. Washington, DC: World Bank Group, p. 6.

World Bank. 2013. Integrating Gender Considerations into Energy Operations. Energy Sector Management Assistance Program (ESMAP). Knowledge Series 014/13; Washington, DC: World Bank.

(C) 2021 by the authors. Licensee MDPI, Basel, Switzerland. This article is an open access article distributed under the terms and conditions of the Creative Commons Attribution (CC BY) license (http://creativecommons.org/licenses/by/4.0/). 



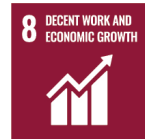

muess d'Lüt neh wie si sy-Anderi gits

"Me muess d'Lüt neh wie si sy-Anderi
e keini" ${ }^{+}$Decent Work and Sustainable Development for the 21st Century: The Case of Wyon AG in Switzerland

\section{Marianthe Stavridou}

† "Me muess d'Lüt neh wie si sy-Anderi gits e keini" in Swiss German means: "We should accept people as they are-others don't even exist".

\section{Introduction}

The question of decent work is a very complex one, especially in a world with multiple issues, discrepancies, and growing inequality. In each country, authorities aim to regulate employment in the formal sector and try to control the informal sector with different methods (SIDA 2004). Depending on the country's political system, several consultations with citizens, economic actors, political parties, government, enterprises and trade unions may be needed. It is important to achieve a consensus on passing employment laws and regulations, and accepting or abandoning supranational non-mandatory regulations and international standards or agreements. However, International Organisations try to define decent work and propose minimum standards for all their member states. These standards should tackle issues like poverty, modern slavery, child labour, migration, and climate change or resource depletion during early globalization (DIHR 2020).

On 25 September 2015, the United Nations' 193 member states voted to adopt the United Nations Sustainable Development Goals (SDGs), a set of 17 goals and 169 targets with the ambition to guide global policy-making until 2030. SDGs were meant to be "a plan of action for people, planet and prosperity" (United Nations 2015a). This Agenda was inspired by human rights discourse, and its goals have been welcomed as a result of democratic participation. Their widespread praise was in contrast with their predecessor "Millennium Development Goals", which received criticism, being described as an "opaque" and "elitist" approach "excluding all but a 'triad' of powerful nations" (Rai et al. 2019; Briant-Carant 2017). In effect, Agenda 2030 aims to encourage development efforts from governments, states, corporations, institutions, International Organisations and the civil society. It also offers opportunities for the 
private sector to collaborate, and sustains collective action to help tackle urgent planetary issues. Despite having support from different stakeholders, this process has also received criticism, being described as a top-down operation with democratic deficits. According to critics, the discussants were not all at the same level, with major actors having a greater influence over the discussion, and with the exclusion of marginalized people. Therefore, this Agenda reflects the mainstream ideas and interests of the most influential discussants, and the prevailing economic sentiment regarding development (Rai et al. 2019).

The definition of decent work in the International Labour Organisation's Work Agenda has four pillars: employment creation, social protection, rights at work and social dialogue. This was elaborated with the participation of governments, businesses and organized labour, a tripartite structure that reflects the structural foundation of this U.N. Agency. Even though this structure creates a unique forum in which the representatives of different parties can freely debate and elaborate international labour standards and policies, it has served for many years as a barrier to the participation of unwaged people, people in the informal economy, in volunteering, in the care economy and in private households (Rai et al. 2019). In reality, ILO marginalized unwaged labour and focused only on the waged part of the economy. However, in 2012, ILO presented a new version of the concept of decent work, accepting the participation of female movements and recognizing the need to address the informal economy that represents, in fact, a fundamental inequality within the labour market. ILO thereafter promoted "decent and productive work for women and men in conditions of freedom, equity, security, and human dignity". It also recognized that "all workers have the right to decent work, not only those working in the formal economy but also the self-employed, casual and informal economy workers, as well as those, predominantly women, working in the care economy and private households" (ILO 2012). However, this new ILO concept was still ambiguous. Its core values-dignity, equality, fair income and safe working conditions (ILO 2012) — may have different interpretations in different political, economic, societal and cultural settings, and are neither quantifiable nor measurable. Moreover, ILO links decent work to productive work and implicitly assumes the existence of a non-productive work; concepts, discussed in the classical and neoclassical political economy in the last two centuries, which influenced the approach to modern management and the discussions on economic sociology and Marxist economic analysis. These concepts also heavily influenced the national accounts. In mainstream economic theory, productivity is the key source of economic growth and competitiveness. In many cases, to remain competitive and attract foreign 
investments, governments decide to lower labour standards at the expense of the most vulnerable workers, and of the economy as a whole. The concept of decent work in Goal 8 follows the ILO Decent Work Agenda, and is related to economic growth and productivity. It is one of the most important Goals, creating linkages with the ten other Goals (Le Blanc 2015), but also tensions and contradictions.

This chapter aims to challenge the idea of decent work related to productivity and economic growth, and questions the concept of decent work for the 21st century. For that purpose, it examines the business model of high-end technology Small and Medium Enterprises (SMEs) in Switzerland, in which ethical values, focus on human needs, and democratic decision-making process prevail over economic growth and productivity. The chapter frames this business model within the Swiss Economy and discusses SDGs, highlighting tensions between the SDGs and within Goal 8. Finally, it aims to propose a new approach to the concept of decent work, taking a human-centred perspective.

The Swiss SME ecosystem is multifaceted. Thus, this paper presents the case of Wyon AG, a company that operates in a valley of Appenzell, as an example of a long-term investment in people, planet and prosperity. Wyon AG creates a new paradigm of entrepreneurship and embedded economy, transcending existing theories of sustainability, responsibility and management.

\section{Wyon AG: "Me muess d'Lüt neh wie si sy—Anderi gits e keini"}

\subsection{Ethical Grounds}

\subsubsection{Dignity}

"Me muess d'Lüt neh wie si sy—Anderi gits e keini", in Swiss German, means: "We should accept people as they are-others don't even exist". This motto is the ethical foundation of Wyon AG, the leading idea that the visionary owner Paul Wyser heard from his father, a Catholic carpenter in the protestant valley of Basel, where he grew up. It is also the foundation on which he and his family built the company from the ground-up twenty years ago and the most important ethical principle linking the past with the present and future generations. In this sense, the first condition of ILO - dignity - is given in the human-centred approach with which the owners developed their business: you cannot change human nature; you must accept it and make the best out of it. Human dignity is the state or quality of being honourable or respectable, and the value behind all other human values. Democracy, in particular, can only be supported on a foundation of human dignity and requires legitimacy, inclusion and accountability, values also linked to ILO's second condition of equality. 
Accepting people as they are, respecting them in their existence and treating them as equals is inscribed in Article 1 of the United Nations Universal Declaration of Human Rights: "All human beings are born free and equal in dignity and rights. They are endowed with reason and conscience and are to meet one another in a spirit of brotherhood" (UNDHR 1948). This acceptance, with dignity and equality, brings benefits to any society, organization or human activity. According to the Stanford Encyclopedia of Philosophy, moral equality is the view that equality is central to justice, that all individuals are entitled to equal respect and that all human persons are equal in fundamental value or moral status [ ... ] It is a fundamental principle of most forms of democracy (SEP 2001).

\subsubsection{Trust}

Growing up as a member of a large family, Paul Wyser learned to trust and be trusted; in society, he learned to respect cultural differences and also endure exclusion and discrimination because of his family's cultural/religious differences. Therefore, he learned to trust within the family and build strong relations that helped him to design the human journey of his company. Indeed, trust implies responsibility and conveys security and wellbeing, regardless of any incongruity. In Wyon AG, ethical values are materialised in their entrepreneurial acts, not only towards employees but also towards society and the environment.

Above all, the corporate structure is egalitarian. The company has a flat and lean management style, with employees sharing equal responsibility and power. The owners/managers encourage the employees to think and act like entrepreneurs and be active members of the teams in which they work. Employees work collaboratively on tasks and behave as equals. Even though owners/managers delegate responsibilities, the employee teams take part in the decision-making process, bring their development ideas forward, work together on solutions, and decide on the hiring of new employees and development of new products. After all, they know the company best. Relationships with the customers are also direct and personal, with solid ties and frequent direct collaboration.

This management structure reflects the Swiss tradition of direct democracy: employees are actively involved in the development of the company and the wellbeing of the workforce, in the same way that citizens are actively involved in the political and social process. It brings success and transforms employees by giving them appropriate space to shape the company as a joint project, and to thrive. Open dialogue, cooperation and transparency in communication are also of great benefit in creating a common ethical basis and resolving issues more openly and transparently. 
The assumption and acceptance of responsibility, moreover, is a crucial factor in the company's success. In other words: The success of Wyon AG is co-designed with the employees in a long-term relationship, in which the personal pronoun "we" stands above the pronoun " $\mathrm{I}$ ", as the team personality stands above the individual. This approach creates a common culture, and a basis for working together and reaching a consensus on solutions. It allows people to live and work as equals, and the company to flourish.

\subsubsection{Fair Income}

Wyon AG not only gives employees responsibility and decision-making power but also, under certain conditions, a part of the company's shares, especially after Paul Wyser's retirement and the gradual succession of management to the next generation. "How much money do you need to be happy?" Wyser asks, justifying the decision to keep only a small amount of shares for him and his wife and offer the rest to the next generation and the employees. This fact not only respects ILO's core value of fair income, but also transforms the employees into co-owners that invest in and develop their own company, establishing tight relationships and avoiding turnover. To this end, employees are trained as apprentices from the outset, and later they mature as specialists in order to know and innovate the products, finding solutions for the company's common advantage.

Financial independence is essential for the decision-making process, as much for the present as for the future of the company. For this reason, Paul Wyser invested his own money to start the company, and today the company invests its profits in research and development, innovation, sustainable development, and in people's wellbeing and infrastructure. Paul Wyser and the next generation of management do not believe in "modern managers who strive for short-term profits and gains", as he emphasises.

The modern manager's perspective reveals a utilitarian approach to business and responds better to the question "how much money is in it for me?". Paul Wyser's question focuses on happiness and human values.

Wyon's owners/managers believe in sustainability that requires long-term engagement and trustworthy relations. To sustain a company for people, the planet and prosperity, you need to have a long-term perspective, without dependencies on banks, stock exchanges or individual private investors and investment funds. Such dependencies could hinder long-term success and change the management focus from people-centred to short-term and profit-oriented, in Paul Wyser's opinion. Independent SMEs need people with a vision of creating a safe and transparent work 
environment, putting people and their needs at the centre of focus and transforming the business environment into creative joy and satisfaction.

\subsubsection{Cooperative Principles and Empowerment}

Since the beginning of this venture, Paul Wyser wanted to "lead the company beyond money". Therefore, personal relations with employees, customers, suppliers, the community and other stakeholders are of great importance. Humans are the most important stakeholders for Wyon AG. To this end, the company grew from a family business into a real social enterprise in only twenty years. Wyon AG is a privately owned company, not a worker cooperative. However, cooperative principles are applied to fit the company needs.

Cooperatives and worker-owned enterprises could re-imagine and re-configure the economy as a whole, because the principles of their governance differ drastically from those of the conventional hierarchical business management. During the financial crisis of 2007, the idea of democratic management in organizations and communities rose in the world and cooperative business structures surfaced as more resilient. According to ILO, "cooperatives have been more resilient to the deepening global economic and jobs crisis than other sectors" (ILO n.d.). In Switzerland, cooperatives and their principles are well known. The country has more than 9.600 cooperatives in different sectors of the economy, with over half of the population working within a cooperative business. The political system, well known as a direct democracy, needs the cooperation of people, along with the Cantons and their consensus, in advancing policy in a particular direction.

In 2012, the United Nations declared the year as the International Year of Cooperatives to highlight their contribution to social and economic development, in the creation of employment, reduction in poverty and in encouraging integration (Cheney et al. 2014). Cooperatives are people-centred enterprises, with democratic participation that aims to create sustainable businesses which generate long-term jobs and prosperity, based on common values and principles and putting fairness and equality first (Rochdale Principles 1934, ICA 2021). Human-centred principles like anti-discrimination, motivation and rewards, democratic and open participation in decision-making, equity, autonomy and independence, education, training and information, and concern for the community are some of the cooperative principles that also apply to Wyon AG. The target is to empower employees and make them active members of the teams, the company and the community. Empowerment is also given great attention in the SDGs because it is the bundle of measures that increases the degree of autonomy and self-determination of individuals and communities. 
Empowerment is the basis of democratic participation. It enables people to represent their interests in a self-reliant and self-determined manner. Furthermore, it motivates people to act responsibly. The action of empowerment refers to both the process of self-empowerment and professional support for people.

As part of a certain business approach, empowerment is used in participatory management and decision-making processes. It is defined as the sharing of various organizational factors, i.e., information, reward, knowledge or power of the employees of lower grades (Bowen and Lawler 1995). As a multi-faceted approach, empowerment helps businesses to build community capacity, create social capital, ensure compliance and improve the legitimacy of the decision-making process, and offer transparency and inclusion. It enables the most effective decision-making, because larger groups of people make better decisions than small groups of experts. It also helps to resolve agreements by having a shared understanding of the business reality, building trust and confidence and receiving a licence to operate at a community level (Sharma and Varma 2011; Kao et al. 2016).

\subsection{Externalization of Ethical Values}

\subsubsection{The Environment}

Having intrinsic anthropocentric values and teamwork on equal terms, Wyon AG sets a further milestone, with the externalisation of ethical values. First of all, the very same building of Wyon AG is designed to be in harmony with nature. The company is located in Appenzell Steinegg, a small village with 1000 inhabitants in the Rüte district. The village lies at the western foot of the mountain Fähneren, about $2 \mathrm{~km}$ southeast of Appenzell. As a typical Swiss village, it needs environmental protection. For this reason, the $4000 \mathrm{~m} 2$ building is not only designed to be environmentally friendly, but also to save energy and resources using the latest technologies. A heat pump provides heating with geothermal probes located in the main building. A chiller provides cooling, and the "free-cooling" energy can be buffered in the existing storage tank, and thus be used to optimise the system in terms of further energy. A mechanical ventilation method ensures a pleasant indoor climate and a very sophisticated IT system optimises energy consumption and security. The optimisation of resources and the in-house production of energy are important issues for any company. Thus, recycling and reuse of plastic and other materials is embedded in the corporate praxis, and the in-house energy production from renewable sources ensures energy sufficiency and protection of the environment. The electro-technological facility is integrated into the building structure, which creates a U-shape with an inner garden, water fountain and plants. This garden is perfectly 
embedded in the topography, designed to offer relaxation, peace and inspiration to the employees. The flat and lean democratic structure of the operations is also present in the open and shared workspace, and the clean and pure production area is also symbolically painted white. The team offices are designed for individual work that requires a high degree of concentration, with short paths to production areas and always-open doors. Rooms for brakes, patios and the inner courtyard are also used for crosscutting meetings.

\subsubsection{Products and Collaborations}

Since people were already the most crucial element in an early stage of the company's development, products were conceived for the improvement of human health, within the range of the auricles, in diabetology, ophthalmology, gastro-enterology and orthopaedics. Wyon AG specializes in the development and production of rechargeable Li-Ion batteries in small and micro-sizes and has patented plastic technology combined with the stacking technology and micromechanic competences. The batteries are smaller, come in any custom shape and achieve the highest capacities for their volume. Recycling and control of the supply chain is also part of the company's operations in order to optimise, save resources and create a circular economy. Such micro-technological know-how is not only needed in medicine, but also in aerospace and military, industries that could generate high profits for the company. However, the human-centred approach of the owners does not allow cooperation with such industries. On the other hand, cooperating with customers in the medical field requires solid personal relationships on equal terms and a deep understanding of human needs, unison in ethical values, along with a vision for innovation, and the improvement in human life.

High-end technology and innovation are essential elements of success for an SME. Switzerland is nonetheless an expensive production location. In order to sustain long-term operations, preserve jobs and keep employment in the regions sound, the SMEs should bring niche technologies to the global market and be one step ahead of the global competition. Today, Wyon AG is a high-end technology firm with no direct competition, which exports $90 \%$ of its products to Australia, Asia and Europe. Moreover, for sustaining long-term relations, the workforce should feel welcome in the working environment and be able to be integrated into teams. To this end, Wyon AG has supported education and apprentices in the Appenzell region since 2013 through the Wyon-Foundation. This foundation reinforces and amplifies the presence of the company in the local and regional communities. The foundation also supports 
the very efficient Swiss technical education system and helps the region thrive, not only as a workplace but also as an innovator of products, markets and society.

With its approach, Wyon AG not only creates new working places but also new standards in business and the economy. It applies an inclusive model to benefit not only the company, but also society, the environment and human life. As Paul Wyser believes, "the world is the market" and, in it, people's needs drive innovation and prosperity.

\section{Switzerland and the Small and Medium Enterprises}

\subsection{Switzerland as a Hub for Technology and Innovation}

Switzerland is one of the world's leading countries in manufacturing and innovation and, according to statistics, it has one of the highest GDP per capita in the world. Despite international developments, adverse trends and de-industrialization since 1970, the country was able to maintain its leading position because of its strong focus on providing people with high standards in education and health care. Switzerland also maintained high-quality technology and production, and knowledge-based manufacturing, as well as an exceptional public infrastructure that permits the development of businesses, even in the most remote parts of the country. Political stability, a transparent legal system, efficient capital markets, medium-low corporate tax rates and extended social security (CIA 2019) are also essential for the country's competitive advantage. According to the Competitive Industrial Performance Index 2017, the country was ranked 6th in the world, due to the high value-added per capita in the manufacturing industry, the high degree of industrialisation and the high proportion of medium- and high-tech activities (PwC 2018). According to the 2018 PwC report on Switzerland, two main factors are essential for the continuing growth of the Swiss manufacturing sector over the next four years: robust international demand, and the rise in domestic consumption. Both may boost manufacturing and innovation and place the country as one of the leaders in Industry 4.0; however, it may also cause a significant environmental impact due to production methods and the use of large quantities of natural resources.

To tackle the arising challenges, the 2013 Green Economy Action Plan (BAFU 2020) and the Sustainable Development Strategy 2016-2019 (ARE 2016) anticipate a series of various measurements, prioritizing the areas of consumption and production, waste and raw materials, and reinforcing the public dialogue in order to conserve natural resources, make consumption environmentally friendly and strengthen circular economy. 
Sustainable consumption and production also require some changes in consumer behavior. It requires an increase in consumer awareness and environmentally friendly decisions when it comes to purchase and use physical goods. Thus, sustainable industrialization is vital within the Sustainable Development Strategy 2016-2019, and in the realization of the UN Sustainable Development Goals: The federal government has declared its aim to transition to a resource-saving, sustainable economy which fulfills its responsibilities along the entire value chain (Goal 12, ARE 2016, p.18) and to build resilient infrastructure, promote inclusive and sustainable industrialization and foster innovation (Goal 9, ARE 2016, p.16).

The cooperation of the private sector is essential to achieving these targets. In particular, the industrial sector may advance the debate on sustainability, implement different Action Plans, and adopt programs of new measures and other initiatives. The Corporate Social Responsibility Position Paper and Action Plan of the Federal Council (SECO 2020), the 2016 National Action Plan for the implementation of the UN Guiding Principles on Business and Human Rights (Federal Council 2016), and the 2013 Background Report on Commodities are headed towards this conclusion (Federal Council 2013), and are expected to help the industry tackle sustainability issues.

Furthermore, the Federal Policy supports and strengthens the commitment of all actors as a means to a more sustainable future and a circular economy. It is a clear expectation of the Federal Council that Swiss-based companies have to fulfil their human rights obligations and their responsibilities towards the environment in all their activities, and that the Federal Council attempts to assume a role-model function regarding its consumption patterns (PwC 2018).

\subsection{The Agenda 2030 in Switzerland}

The Swiss Confederation adopted the 2030 Agenda in 2015, due to its long tradition of pursuing sustainable development. According to the baseline assessment of 2017, SDGs were well-established in the legislation at multiple levels of administration. However, more efforts are needed to ensure cohesion and policy coherence, reconcile national and global perspectives and to level existing discrepancies (OECD 2020; EDA 2016, 2018, 2020). The recent results of the SDG implementation and measurements, however, attest some serious issues that also heavily impact society and the environment:

Poverty: Despite positive developments and a strong economy, the Swiss Social Statistics report of 2019 uncovers that, in 2017, income poverty increased, and around 675,000 people were affected. The poverty rate rose from $7.5 \%$ to $8.2 \%$ between 2016 and 2017, and $4.3 \%$ or 165.000 people were classed as the working poor. Long-term 
unemployment rose as well, and seniors were heavily impacted (BfS 2019). Despite being employed, the following groups of people are significantly affected by poverty: (a) those who work only for certain parts of the year, (b) part-time employees, (c) self-employed people, (d) employees with a temporary contract, and (e) those employed in small businesses.

Equality: The Federal Office of Gender Equality attests that there is not equal pay for women and men, despite the Federal Constitution enshrinement of 1981 and the Gender Equality Act of 1996. Women in Switzerland earn, on average, 18\% less than men, and only $56 \%$ of the pay gap can be explained by objective factors like years of service or professional status and qualifications. A total of $44 \%$ of this gap remains unexplained and the causes are potentially discriminatory, such as traditional gender roles, the choice of education and training, the gender-based division of family and domestic work as well as of paid work, gender-based distortions in the evaluation of performance or general discrimination in the labour market.

Unpaid work: According to the Federal Statistical Office (BfS 2017), unpaid work in Switzerland is worth approximately CHF 408bn and corresponds to 9.2 billion hours. Time spent on unpaid work exceeds that of paid work: on average, each person worked 1.320 hours/year and women took on $61.3 \%$ of the unpaid work volume. In contrast, men took on $61.6 \%$ of paid work volume. Housework without childcare makes up three-quarters of the total volume of unpaid work (77\% of 7.1 billion hours). Care for children and adults in households can be measured at 1.5 billion hours/year ( $16 \%$ of the total volume). A total of 660 million hours were spent volunteering ( $7 \%$ of the total). More time was spent on informal volunteering (436 million hours) than on institutionalized volunteering (224 million hours).

In a society, any kind of inequality and discrimination has macroeconomic implications, as lower pay or unpaid labour harms social insurance, pensions and tax revenues. As women are not equally present in the labour market, the economy benefits from a far smaller pool of high-skilled people, and competition between companies may suffer from this distortion. Social exclusion in the market and society jeopardizes social peace (EBG 2019), and creates biases in social and economic data collection and, ultimately, in the shaping of an inclusive and egalitarian future society. However, the Federal Government encourages the labour market participation of older people and vulnerable groups, and the employment rate of women and young people is increasing, while the wage gap between women and men decreases (SDG 8.4, SDG 8.b, SDG 8.6, EDA 2016, 2018, 2020).

Switzerland's commitment to the Agenda 2030 is long-term commitment to sustainable development. On this path, questions about what we understand about 
sustainable development and how we can achieve sustainability on a local, regional or global level still remain open, and so does the role of the actors in this path and their responsibilities. Unfortunately, the Federal Council in the Swiss Growth Policy 2016-2019 does not focus on the aforementioned issues. It instead focuses on increasing productivity, which creates contradictions and clashes with the very essence of the SDGs as an Agenda for the people, planet and prosperity.

\subsection{Swiss SMEs: A Different Approach to Business and Development}

According to the Federal Statistical Office in 2018, SMEs in Switzerland account for more than $99 \%$ of businesses in the market-driven part of the economy (BfS 2018). Out of a total of 608,952 businesses, 591,016 are SMEs and employ 3,039,326 people.

SMEs are locally embedded companies, well known in the communities in which they operate and recruit people. They understand ethical responsibilities as an inherent part of day-to-day work, and as a moral activity. Cultural context, direct democracy, subsidiarity, decency and acceptance of any kind of difference constitute the basis of their operations. Their owners are mainly families that also manage the business, maintaining strong ties with the local cultural, social and political realities. SME owners/managers have a deep awareness of the impact and the effects of their activities. Thus, they aim to operate sustainably and responsibly, and they strive to develop stable long-term relations with their communities. They do not need to formalize any Corporate Social Responsibility practice or publish social activities because their stakeholders are aware of their contributions (Stavridou 2018; Stavridou and Vangchuay 2017; Looser and Wehrmeyer 2015). Consequently, for SMEs, local embeddedness has a greater significance than it does for multinational or publicly traded companies, which operate remotely and formalise their Corporate Social Responsibility targeting to justify their activities and satisfy a much more diffuse audience.

This SME approach has a long tradition in Switzerland, starting with industrialization, which created adaptable forms of business in the community. On one hand, it created the figures of the Swiss Patriarchs, well-known pioneers with large industries, innovators and politicians, who also advanced social issues. On the other hand, it created the tradition of cooperative businesses with a lean structure and democratic decision-making process, which empower people to decide on the presence and future development of the company and assume responsibility. As of today, SME owners consider their success to be a continuum of six overlapping key drivers (Figure 1), as discussed in a paper by Looser and Wehrmeyer 2015: 


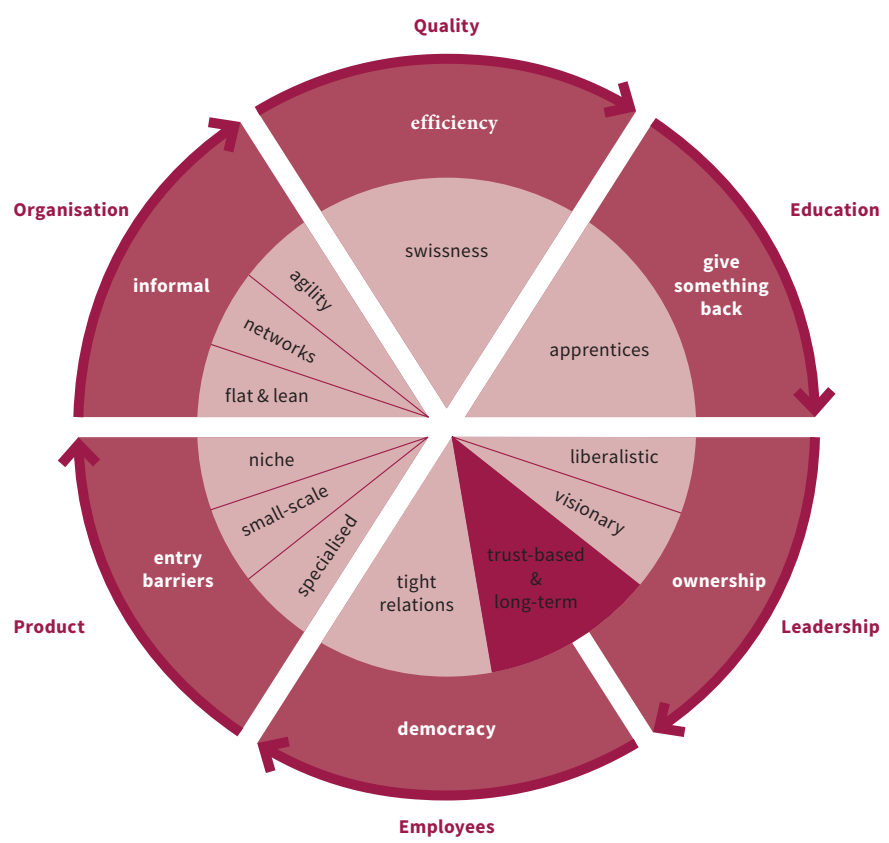

Figure 1. Key drivers to success for SMEs according to owners. Source: Graphic from Looser and Wehrmeyer 2015.

Ownership is the most important key driver. Owners are also managers of their business, leading by vision. They take a long-term perspective into account, as opposed to managers of big corporations, who are short-term, profit- and gain-driven. Financial independence is paramount for them, preferring to do business without any state intervention, regulation or other formalization. This liberalistic approach allows them to consider leadership as a personal ability and enables the assumption of responsibility for the present and future of the company. Owners/managers think in a distinguished manner, in which vision, values and task-orientation are the path to advancement and success.

This vision-driven approach to ownership leads a lot of the owners/managers to transform employees to be owner-managers themselves. Such a transformation, as well as the relationship between employees and owner-managers, is based on egalitarian principles and the democratic tradition. Democracy is the second key driver. Democratic principles help them to create real, trust-based and long-term, tight personal relationships. Still, even if there is not an absolute democratic approach deployed within the companies, a participatory approach with the owner-managers, taking the employees' opinions into account, is always in place. 
Small and Medium Enterprises are highly specialized. They offer a niche product and a customised small-scale production, working very closely with their customers. They maintain excellent personal relations and adapt production to their customers' needs and desires. The agility with which companies customise products and services positions them as unique in the market and poses high entry barriers to others, making it almost impossible for competitors to enter the same market. Innovation, a niche product and high entry barriers are the third key driver to their success.

The fourth key driver is the informality with which the organization takes care of its customers' needs. The externalisation of the internal flat and lean structure, the agility in response to customer needs and the importance and drive of their networks are the traits that make the company agile enough to respond to its environment with efficiency.

Efficiency is the fifth key driver and accounts for quality. It also plays an important role in the specialization and niche products, and it is a further crucial factor for success. The quality of the organization reflects upon Swissness and its positively connoted attributes: fairness, precision, reliability, political stability, naturalness and cleanliness. SME owners/managers understand Swissness as some sort of import protection, and as a compass to follow.

To give something back to the society by educating the workforce is the final driver for success. The owner/managers put a system of apprenticeships in place, educating their workforce from the beginning. They establish ethics personally during the process of work socialization, offer adequate education for their company's advancement, and help the company gain qualified employees that understand responsible business practices.

This approach to business development is an important characteristic of Swiss middle-class capitalism. In cases like Wyon AG, cooperative structures take place and the companies become real social enterprises, focusing on human needs instead of profits, gains, or conventional growth. Switzerland is facing severe issues in the implementation of Agenda 2030, despite competitiveness and a dynamic globalized economy. A Wyon AG approach to sustainability could become a major example for a new concept of decent work, and further advance the implementation of the Agenda 2030. 


\section{Discussion}

\subsection{The Difficult Relationship between Decent Work and Economic Growth}

Economic growth is defined as an increase in goods and services produced per capita over a period of time, measured on a national scale by taking the monetary worth of the nation's goods and services over this period into account. Conventionally, economists create statistics by measuring growth as a percentage rate of increase in real Gross Domestic Product (GDP) over a year. The amount of wealth, divided among the population (GDP per capita), acts as a metric for determining a country's economic output per each person living there. As such, it represents the basic statistical information for a country's performance assessment and its international comparison. However, these measurements are crude and do not reflect socio-economic realities outside of the stat-sheets. Arguably, the wealth of a nation is spread among far fewer people, and rich nations with smaller populations tend to have higher per capita GDP.

The United Nations action for people, planet and prosperity is a supranational program that follows a Triple Bottom Line (TBL) as a reference: social, environmental and economic factors should lead to sustainable development for the years to come. Still, the concept of decent work does not explain how the planet will be able to achieve prosperity in terms of growth and productivity, concepts developed in the 20th century that have influenced the realities and the contradictions we live in today.

Goal 8 does indeed "promote sustained inclusive and sustainable economic growth, full and productive employment and decent work for all" (United Nations $2015 b)$. The belief is that "Sustained and inclusive economic growth is a prerequisite for sustainable development, which can contribute to better livelihoods for people around the world. Economic growth can lead to new and improved employment opportunities and provide greater economic security for all. Moreover, rapid growth, especially among the least developed and other developing countries, can help them reduce the wage gap relative to developed countries, thereby diminishing glaring inequalities between the rich and poor" (United Nations 2015b). Goal 8 has received criticism for relating decent work to economic growth and its measurements, and for neglecting societal realities in different parts of the globe (i.e., in African countries, informal work is standardised). It has also been criticised for neglecting the impact of rapid economic growth related to industrialisation and urbanisation, which have led to extremely severe air pollution and caused increasing negative effects on human health, visibility, and climate change, as the example of China shows (Li et al. 2016).

The debate on economic growth has been ongoing throughout 19th and 20th century. Above all, the idea that the economy can infinitely grow contradicts physical 
limits and boundaries, and it is not realistic (Mill 1848; Keynes 1945; Meadows et al. 1972; Jackson 2016; Raworth 2017; Chesney 2017). Major questions in the growth debate include all aspects of human life, from deprivation and poverty to climate change. Questions on how humans can end deprivation and poverty without a growing economy, how humans can end ecological degradation with a growing economy, and how it is possible to create decent work in a fast-growing economy have multiple answers that exceed the frame of this work. However, we note some general considerations that could lead us to respond to the central question of this chapter: How can we challenge the existing concept of decent work to truly fit the needs of people, planet and prosperity?

\subsection{Critique on SDG 8}

To begin with, economic growth cannot a priori guarantee decent work or prosperity. Even in developed economies, poverty rates are high, and human and gender inequality persists. The example of Switzerland is paramount for these features.

Secondly, the typical measurement of economic growth is the country's GDP. Nominal GDP does not capture the complexity of working reality or of working conditions. It does not reflect differences in the cost of living or the inflation rates between countries or regions. It gives no information about the production of assets, the depletion of human and environmental resources, the violations of labour rights—some of these are also prevalent across the Globe (i.e., the gender pay gap, sexual harassment, the dismissal of pregnant women) —or the impact of precarious working conditions on households and human lives (Fudge and Owens 2006). Moreover, it does not reflect on the informal economy, which forms a significant portion of the economy, ranging from less than $10 \%$ to over $40 \%$ of the GDP (IMF 2019) even in European countries. Additionally, unpaid work in general, be it volunteering, care or household maintenance, is important labour for the functioning of the economy (Sotiropoulou 2014; Wry 2015). However, even if people active in the informal sector enter the formal sector and create tangible results in the GDP, the informal sector, such as unpaid domestic work, care labour or volunteering, would still be excluded from measurements and would not be considered as work generating revenues or even as productive labour (Stiglitz et al. 2018; Rai et al. 2019).

Apart from a few countries that calculate unpaid work within a Satellite Household Account to the GDP (OECD 2018; BfS 2017), SDG 8 does not address issues of gender equality, time poverty or depletion of human resources and quality of life related to economic growth; issues that create requirements in the provisions of public 
service, infrastructure, and social protection policies. A possible integration of the Satellite Account into the GDP measurement would lead the economy towards a more egalitarian approach in the 21st century, as well as the abolition of gender-segregated labour markets that depend heavily on unpaid work. SDG 8 further directly contradicts the SDG 5, which strives to address human equality, and recognizes and values unpaid care and domestic work (Agenjo-Calderón and Gálvez-Muñoz 2019; Wry 2015; Sotiropoulou 2014; Antonopoulos 2009; Branisa et al. 2013; Rai et al. 2019; BfS 2017).

Third, the annual growth of $7 \%$ in less developed countries, as promoted by Goal 8 , would exceed earth's biocapacity by $50 \%$, and accelerate global warming. Global production and consumption could also rise above current limits. Scholars believe that Goal 8 neglects the fact that UN Agenda 21 proposes to increase economic growth sustainably: "economic growth should not come at the expense of environmental degradation". Furthermore, the main idea is that governments should seek to change institutional structures "in order to enable more systematic consideration of the environment when economic decisions are made" (Briant-Carant 2017). In addition, Goal 8 fails to provide time-bound measurements and measurable targets, or account for the lack of data and other information that could be misleading in the discussion on sustainability. This is because the fundamental contradiction between resource limits and economic growth remains. Furthermore, Goal 8 is also in opposition to Goal 13, which demands urgent action to combat climate change and decarbonise the economy at breakneck speed, six times faster than any other effort in history (Hickel 2015).

Therefore, if humanity wants to combat climate change, it should abandon the blind believe in economic growth and discuss the effects of this on the planet and people. It is also important to establish a balance between developed and underdeveloped economies (Hickel 2015; UNFCCC 2015; Briant-Carant 2017; Rai et al. 2019), and policies that target economic development related to social cohesion and environmental stability (Katsoulakos and Katsoulacos 2007). A long-term perspective beyond GDP should be essential.

Goal 8 (8.2) moreover, aspires to "achieve higher levels of economic productivity through diversification, technological upgrades and innovation, including through a focus on high-value added and labour-intensive sectors" (United Nations 2015b). This implies that technological upgrading and innovation would result in social upgrading. In reality, labour-intensive industries (i.e., agriculture, mining, hospitality or food services) use social markers like gender, ethnicity, class or race to shape labour relations and do not necessarily translate gains into higher wages or the advancement 
of labour rights, such as freedom of association and collective bargaining (Ruwanpura 2016; Barrientos et al. 2012). In this sense, technological upgrades do not automatically lead to either economic or social upgrades, or to human and gender equality, or to full and productive employment, decent work and equal pay for work of equal value for all women and men by 2030, as SDG 8.5 urges member states to achieve.

By relating economic growth and productivity to human labour for wages and benefits, Goal 8 neglects the role of labour in life above the need for a survival wage. The role of labour beyond existential needs is to boost creativity and innovation, and ensure and facilitate movement between jobs (World Bank 2019). Creativity and innovation are also important in the effective decoupling of all existing elements in order to create new economic models that could respect human life and nature much more than existing ones. According to the World Bank, as of today, in developing economies, 8/10 people receive no social assistance and 6/10 work without insurance. In developed economies, the payroll-based insurance model is challenged by non-standard contract working arrangements. The World Bank (2019) proposed rewriting the social contract and investing in human capital (public health and education), ensuring a livelihood with a societal minimum that provides support independently of employment. "We need new ways to invest in people and to protect them, regardless of their employment status", and we need to rethink the social contract and adjust it to "the changing nature of work" (World Bank 2019, p. VIII).

In parallel with its emphasis on GDP per capita growth, SDG 8 (8.10) aims to "encourage and expand access to banking, insurance and financial services for all" (United Nations 2015a). Job creation should be the critical element of eradicating poverty, forced labour, slavery and human trafficking. However, Goal 8 does not reflect on the damaging effects that the lending practices of major financial institutions can have on poor people. Lending is a way to proliferate inequality and poverty, and to advance human dependencies. The risk of over-indebtedness in under-resourced segments of society is high. By promoting access to financial services, formalisation and growth of micro-entrepreneurialism as a route out of poverty (target 8.3 ), SDG 8 propagates the continuous financialisation of the economy in a way that obscures a possible underlying process of exploitation in the informal sectors, and the unequal division of labour. Despite the euphoria about microfinance as a development-oriented policy and as a means of lifting people out of poverty (Briant-Carant 2017), critical voices arose against microcredits and their inefficiency in formalising informal micro-, small- and medium-sized enterprises and creating higher-income possibilities. Excessive interest rates charged to borrowers, aggressive lending policies, and the coercive or even violent methods of recovery applied 
by some microfinance institutions and local field officers, have led borrowers to over-indebtedness and played a role in suicides. Additionally, the lack of information and education given to borrowers sank them into a vicious cycle of debt. In many cases, borrowers used microcredits from one lender to meet the interest obligations of another lender, or became informal lenders for the same reason, complicating the relationship between formal and informal lenders (Arp 2018; Arp et al. 2017). However, even if the result of microcredits was to lift people out of poverty and, along with micro-entrepreneurship, it could become a fully-fledged solution, "it's not enough to just assume that because a marginalised group has made advances in society, they aren't still marginalised in deeper, more fundamental ways" (Wry 2015).

Financial capital as such has no interest in supporting livelihoods, ensuring education and jobs, creating equal opportunities, or recognizing any value in social reproduction, culture and diversity. It has no interest in democratic processes or in taking action for people, planet and prosperity, as the Agenda 2030 for sustainable development suggests. Financial capital seeks only to ensure that households become consumers of its products (Himmelweit 2017).

Finally, Goal 8 (8.a) proposes the installation of an "Aid for Trade" procedure and provision of technical assistance. Nations that receive aid should lift trade restrictions and make structural adjustments within their countries. "Aid for Trade", as a policy, is similar to the Structural Adjustment Programs (SAPs) of the IMF and the World Bank that, until now, created further inequality by deregulating the labour market at the expense of women and vulnerable people and leading countries to severe austerity, with devastating results for public health and education (Sotiropoulou 2014).

A last critical point regarding all SDGs is the quality of data and measurability of advancement. The ongoing developments in the internet economy (i.e., growing centralisation, monopolisation and consolidation, threat to net neutrality, higher volumes of bot traffic or biases within the data) challenge the statistics and eventually lead to a growth in unreliable information (MacFeely 2019; Internet Society 2020).

The SDGs call on humanity to achieve harmony with nature, protect the planet from degradation, and take urgent action on tackling climate change (Goal 6, 12, 13, 14, and 15). They create tensions by calling to drive economic growth and assuming that growth-as-usual and trade-offs, in favour of growth over wellbeing and ecological viability, are feasible (Gupta and Vegelin 2016). In this context, Goal 8 contradicts several other Goals and lacks an explanation of how to end poverty (Goal 1), because its understanding of decent work remains attached to the mainstream economic paradigm and its conventional measurements. 


\subsection{Lessons for a New Concept of Decent Work}

Twentieth-century mainstream economic thinking has influenced the United Nation's concept of decent work by relating it to economic growth. As argued, this concept has received criticism for contradicting other SDGs and focusing on GDP growth. In fact, the failure of the growth theory lies in the absence of understanding that humans are social beings that evaluate wellbeing based on what they see around them (Rogoff 2012). In the political and corporate debate that began in the early 1990s, corporate responsibility issues have gained prominence, driven by the realisation that development based solely on economic growth paradigms is not sustainable (Katsoulakos and Katsoulacos 2007). People do not rely on absolute numbers or crude measurements but on experience, life realities, education, ethics and other psychological factors.

For this reason, the 21st century requires a new concept of decent work that will be independent of the idea of economic growth; a new path for people, planet, and prosperity that relies on humans, their needs and their rights; in other words, a human-centred approach. Humans are able to create societies that prosper; therefore, businesses should integrate human values into their core interests. Fundamental human rights have already been established as indispensable norms for international peace and security in the Universal Declaration of Human Rights. They were acknowledged as such by the signatory states (UNDHR 1948). For this reason, our societies need a new economic model, in which markets and the economy can work optimally. This can only happen if businesses are embedded within social rules, customs and institutions, and grounded in the theory of business in the society. Under this model, companies must learn to do things differently and move towards a human-centred perspective. Morality, art, spirituality and creativity are universal abilities and inherent to human DNA (Harari 2018). For this reason, companies should learn to have an active role in human rights protection, support freedom and equality, and become powerful forces in the discourse on the international human rights regimes (Ruggie 2008). If the central question of the twentieth century was "how much money is in it for me?" the 21st century asks, in Paul Wyser's words, "how much money do you need to be happy?" The shift in the mindset is clear: not money for the few in business, but happiness for each individual, is the central point of this approach.

In other words, the 21st century business narrative should include the alignment of business ethics with human rights and values. The human rights concepts (freedom, dignity, equality, justice and fairness) can serve as a compass to define what is right, 
just and fair for the people related to business, community and the environment (Stavridou and Vangchuay 2017; Raworth 2017).

\section{Conclusions}

Using the example of Wyon AG, we found that a new approach to decent work should take on a human-centred perspective. Wyon AG developed its economic activities with people, for people, integrating a different set of values in business and generating a positive impact on society and the environment. In opposition to other companies, which use CSR programs as remedies to their social and environmental impact, Wyon AG generates benefits at multiple levels by investing in human creativity and innovation, accepting differences as natural, and externalising intrinsic values. This path aims to serve and innovate society and the environment. There is no striving for uninterrupted growth, but for the creation of wealth based on ethical principles, human acceptance and understanding. Even the core message, "we should accept people as they are-others don't even exist", is deeply humanistic and contradicts the conventional management belief that there are perfect candidates for every job.

Wyon's business approach has an intrinsic ethical code, which benefits people, society and the environment and contributes to a much more important consideration: a vision of human life in dignity, equality and peace. It is a model for people, planet and prosperity. The approach of other ethical SMEs in Switzerland is similar. They balance the economic part of their activities with social cohesion and environmental stability, having this vision as a priority. Clearly, this approach is easier to apply in a small and medium enterprise that operates locally, sets long-term targets and has a democratic approach, than in a Multinational Corporation that operates remotely and has a short-term vision, with hierarchical structures and obligations to external shareholders.

The economy of the 21st century however, requires a new direction. The financial addiction to GDP growth is the result of the idea that humans are rational individual creatures living in a self-contained market and aiming for the maximisation of gains and profit for themselves. Such a belief accelerated the depletion of human and environmental resources, and even if statistics show a better picture for people lifted out of poverty, the fact remains that, with this approach, even in mature economies, poverty, unemployment, inequality and hunger persist at high rates. The ongoing discussion on development inherent to GDP growth and measured with crude measurements does not satisfy human needs, mainly because it follows a short-term pattern for a long-term approach. Global economic policies should set long-term 
goals, and nominal GDP is a short-term indicator that does not even reflect working realities. In order to tackle issues like poverty, inequality, climate change, or resource depletion, people need to effectively understand correlations, and the socioeconomic reasons behind them. Therefore, it is crucial to find a more human pace at which to prosper, and new forms for business and the economy.

As the SDG is a global path to follow for people, planet and prosperity, this approach should be redesigned, and focused on social and environmental needs. The concept of decent work should especially be decoupled from GDP growth and linked to human rights and values. Flat cooperative structures, democratic relations, dignity, equality, fair income, a safe working place, and, finally, a circular economy form a path that effectively offers a social license to operate in the community and create resilience. Such an approach would take the pressure of growth out of development and help societies to flourish in many different ways. Sustainability and responsibility need a long-term approach, and decent work should be developed on common ethical grounds that are intrinsic to all human actions and lived in everyday life.

Funding: This research received no external funding.

Acknowledgments: I wrote this paper during a tough time, during which I lost my mother. For the openness, kindness, patience and sympathy effectively shown by Paul J. Wyser, I would like to express my sincere gratitude.

Conflicts of Interest: The authors declare no conflict of interest.

\section{References}

Agenjo-Calderón, Astrid, and Lina Gálvez-Muñoz. 2019. Feminist Economics: Theoretical and Political Dimensions. American Journal of Economics and Sociology 78, pp. 137-66. [CrossRef]

Antonopoulos, Rania. 2009. The Unpaid Care Work_Paid Work Connection. Geneva: ILO.

ARE (Federal Office for Spatial Development). 2016. Sustainable Development Strategy 2016-2019. Documents. Available online: https://www.are.admin.ch/are/en/home/ sustainable-development/strategy-and-planning/sustainable-development-strategy2016-2019.html (accessed on 9 March 2021).

Arp, Frithjof. 2018. The 34 Billion Dollar Question: Is Microfinance the Answer to Poverty? Washington, DC: WEF.

Arp, Frithjof, Ardisa Alvin, and Alviani Ardisa. 2017. Microfinance for poverty alleviation: Do transnational initiatives overlook fundamental questions of competition and intermediation? Transnational Corporations 24, pp. 103-17. [CrossRef]

BAFU (Bundesamt für Umwelt). 2020. Available online: https://www.bafu.admin.ch/bafu/ en/home/topics/economy-consumption/info-specialists/federal-government-measures- 
for-resource-conservation/green-economy-action-plan--priority-areas.html (accessed on 9 March 2021).

Barrientos, Stephanie, Gereffi Garry, and Arianna Rossi. 2012. Economic and social upgrading in global production networks: A new paradigm for a changing world. International Labour Review 150, pp. 319-40. [CrossRef]

BfS (Swiss Federal Statistical Office). 2017. Unpaid Work. Available online: https://www.bfs.admin.ch/bfs/en/home/statistics/work-income/unpaid-work. assetdetail.3882343.html (accessed on 9 March 2021).

BfS (Bundesamt für Statistik). 2018. Available online: https://www.bfs.admin.ch/bfs/de/home/ statistiken/industrie-dienstleistungen/unternehmen-beschaeftigte/wirtschaftsstrukturunternehmen.html (accessed on 9 March 2021).

BfS (Swiss Federal Statistical Office). 2019. Swiss Social Statistics Report 2019. Available online: https://www.bfs.admin.ch/bfs/en/home/news/whats-new.assetdetail.9008563. html (accessed on 9 March 2021).

Bowen, David E., and Edward E. Lawler. 1995. Empowering Service Employees. Cambridge: MIT Sloan Management Review.

Branisa, Boris, Klasen Stephan, and Maria Ziegler. 2013. Gender Inequality in Social Institutions and Gendered Development Outcomes. World Development 45, pp. 252-68. [CrossRef]

Briant-Carant, Jane. 2017. Unheard voices: A critical discourse analysis of the Millennium Development Goals' evolution into the Sustainable Development Goals. Third World Quarterly 38, pp. 16-41. Available online: https://www.tandfonline.com/doi/full/10.1080/ 01436597.2016.1166944 (accessed on 9 March 2021). [CrossRef]

Cheney, George, Santa Crus Inaki, Peredo Ana Maria, and Elias Nazareno. 2014. Worker cooperatives as an organizational alternative: Challenges, achievements and promise in business governance and ownership. Organization 21, pp. 591-603. [CrossRef]

Chesney, Marc. 2017. Challenging the Credo of Growth. March 29. Available online: https://marcchesney.com/en/media/marz-2017-wachstum-in-frage-stellen/ (accessed on 10 March 2021).

CIA (Central Intelligent Agency). 2019. World Factbook. 2019. Available online: https://www. cia.gov/library/publications/the-world-factbook/geos/sz.html (accessed on 9 March 2021).

DIHR (Danish Institute for Human Rights). 2020. Sustainable Development through Human Rights Due Diligence. Available online: https://biz.sdg.humanrights.dk (accessed on 9 March 2021).

EBG (Eidgenössisches Büro für die Gleichstellung von Frau und Mann). 2019. Plattform Lohngleichheit. Available online: https://www.ebg.admin.ch/ebg/de/home/themen/ arbeit/lohngleichheit.html (accessed on 9 March 2021).

EDA (Eidgenössisches Departement für auswärtige Angelegenheiten). 2016. Agenda 2030. Available online: https://www.eda.admin.ch/agenda2030/en/home/actualite/news.html/ 
content/agenda2030/en/meta/news/2016/dezember/langfristige-vision-nachhaltigeentwicklung (accessed on 9 March 2021).

EDA (Eidgenössisches Departement für auswärtige Angelegenheiten). 2018. Switzerland implements the 2030 Agenda for Sustainable Development. Switzerland's Country Report 2018. Available online: https://www.eda.admin.ch/dam/agenda2030/en/documents/ laenderbericht-der-schweiz-2018_EN.pdf (accessed on 9 March 2021).

EDA (Eidgenössisches Departement für auswärtige Angelegenheiten). 2020. Swiss Economy Facts and Figures. Available online: https://www.eda.admin.ch/aboutswitzerland/ en/home/wirtschaft/uebersicht/wirtschaft---fakten-und-zahlen.html (accessed on 9 March 2021).

Federal Council. 2013. Background Report on Commodities. Press Release 27.03.2013. Available online: https:/www.admin.ch/gov/en/start/dokumentation/ medienmitteilungen.msg-id-48319.html (accessed on 10 March 2021).

Federal Council. 2016. National Report and Action Plan on Business and Human Rights. Press Release 09.12. 2016. Available online: https://www.admin.ch/gov/en/start/ documentation/media-releases.msg-id-64884.html (accessed on 10 March 2021).

Fudge, Judy, and Rosemary Owens, eds. 2006. Precarious Work, Women, and the New Economy: The Challenge to Legal Norms. In Precarious Work, Women and the New Economy: The Challenge to Legal Norms. Onati International Series in Law and Society. Oxford: Hart Publishing, pp. 3-28.

Gupta, Joyeeta, and Courtney Vegelin. 2016. Sustainable development goals and inclusive development. International Environmental Agreements: Politics, Law and Economics 16, pp. 433-48. [CrossRef]

Harari, Yuval Noah. 2018. 21 Lessons for the 21st Century. London: Penguin Random House. Hickel, Jason. 2015. The Problem with Saving the World. Jacobin. Available online: https: //www.jacobinmag.com/2015/08/global-poverty-climate-change-sdgs/ (accessed on 10 March 2021).

Himmelweit, Susan. 2017. Changing Norms of Social Reproduction in an Age of Austerity. Berkshire: Open University.

ICA (International Cooperative Alliance). 2021. Available online: https://www.ica.coop/en (accessed on 10 March 2021).

ILO (International Labour Organisation). 2012. Gender Equality and Decent Work: Selected ILO Conventions and Recommendations that Promote Gender Equality as of 2012. Bureau for Gender Equality, International Labour Standards Department, Geneva. Available online: https://www.ilo.org/wcmsp5/groups/public/---ed_norm/---normes/documents/ publication/wcms_088023.pdf (accessed on 9 March 2021).

ILO (International Labour Organisation). n.d. Decent Work and Economic Growth Goal 8. Available online: https://www.ilo.org/global/topics/decent-work/lang--en/index.htm (accessed on 10 March 2021). 
IMF (International Monetary Fund). 2019. Explaining the Shadow Economy in Europe: Size, Causes and Policy Options. WP/19/278. Washington, DC: IMF.

Internet Society. 2020. Consolidation. Available online: https://www.internetsociety.org/tag/ consolidation/ (accessed on 9 March 2021).

Jackson, Tim. 2016. Prosperity without Growth: Foundations for the Economy of Tomorrow. London: Routledge.

Kao, Tzu-Yi, Jason C. H. Chen, Ji-Tsung Ben Wu, and Ming Hsien Yang. 2016. Poverty Reduction through Empowerment for Sustainable Development: A Proactive Strategy of Corporate Social Responsibility. Corporate Social Responsibility and Environmental Management 23, pp. 140-49. [CrossRef]

Katsoulakos, Takis, and Yannis Katsoulacos. 2007. Strategic management, corporate responsibility and stakeholder management. Integrating corporate responsibility principles and stakeholder approaches into mainstream strategy: A stakeholder-oriented and integrative strategic management framework\|. In: Corporate Governance. Journal of Business in Society 7, pp. 355-69.

Keynes, John Maynard. 1945. First annual report of the Arts Council (1945-56). London: Arts Council.

Le Blanc, David. 2015. Towards integration at last? The Sustainable Development Goals as a network of targets. Sustainable Development 23, pp. 176-87. [CrossRef]

Li, Guandong, Chuanglin Fang, Shaojian Wang, and Siao Sun. 2016. The Effect of Economic Growth, Urbanization, and Industrialization on Fine Particulate Matter (PM2.5) Concentrations in China. Environmental Science and Technology 50, pp. 11433-2056.

Looser, Stéphanie, and Walter Wehrmeyer. 2015. An Emerging Template of CSR in Switzerland. Corporate Ownership \& Control 12, pp. 541-60.

MacFeely, Steve. 2019. The Big (data) Bang: Opportunities and Challenges for Compiling SDG Indicators. Global Policy 10, pp. 121-33. [CrossRef]

Meadows, Donella H., Dennis L. Meadows, Joergen Randers, and William W. Behrens. 1972. The Limits to Growth. Commissioned by the Club of Rome. New York: Potomac Associates-Universe Books.

Mill, John Stuart. 1848. Principles of Political Economy. London: John Parker.

OECD (Organisation for Economic Co-operation and Development). 2018. Including unpaid household activities: An estimate of its impact on macro-economic indicators in the G7 economies and the way forward. WORKING PAPER No.91. Available online: http://www.oecd.org/officialdocuments/publicdisplaydocumentpdf/?cote=SDD/ DOC(2018)4\&docLanguage=En (accessed on 11 March 2021).

OECD (Organisation for Economic Co-operation and Development). 2020. Measuring Distance to the SDG targets-Switzerland. iLibrary. Available online: https://www.oecd-ilibrary. org/development/measuring-distance-to-the-sdg-targets-2019_a8caf3fa-en (accessed on 9 March 2021). 
PwC (Global Manufacturing and Industrialisation Summit). 2018. Pricewaterhousecoopers Report on Switzerland. Available online: https:/www.gmisummit.com/wp-content/ uploads/2018/09/GMIS-and-PwC-Report-on-Switzerland.pdf (accessed on 9 March 2021).

Rai, Sirin M., Benjamin D. Brown, and Kanchana N. Ruwanpura. 2019. SDG 8: Decent work and economic growth- A gendered analysis. World Development 113, pp. 363-80. [CrossRef]

Raworth, Kate. 2017. Doughnut Economics. Seven ways to think like a 21st Century Economist. London: Random House Business Books.

Rogoff, Kenneth. 2012. Rethinking the growth imperative. Project Syndicate, January 2, 2012. Available online: https://www.project-syndicate.org/commentary/rethinking-the-growthimperative?barrier=accesspaylog (accessed on 9 March 2021).

Ruggie, John. 2008. Protect, Respect and Remedy: A Framework for Business and Human Rights. Report of the Special Representative of the Secretary-General on the Issue of Human Rights and Transnational Corporations and Other Business Enterprises, John Ruggie. Available online: https://media.business-humanrights.org/media/documents/ files/reports-and-materials/Ruggie-report-7-Apr-2008.pdf (accessed on 9 March 2021).

Ruwanpura, Kanchana N. 2016. Garments without guilt? Uneven labour geographies and ethical trading-Sri Lankan labour perspectives. Journal of Economic Geography 16, pp. 423-46. [CrossRef]

SECO (Swiss State Secretariat for Economic Affairs). 2020. CSR Position Paper and Action Plan of the Federal Council. Available online: https://www.seco.admin.ch/seco/en/home/ Aussenwirtschaftspolitik_Wirtschaftliche_Zusammenarbeit/Wirtschaftsbeziehungen/ Gesellschaftliche_Verantwortung_der_Unternehmen.html (accessed on 9 March 2021).

SEP (Stanford Encyclopedia of Philosophy). 2001. First published Tue Mar 27, 2001; substantive revision Wed Jun 27, 2007. Available online: https://plato.stanford.edu/entries/equality/ \#DefCon (accessed on 9 March 2021).

Sharma, Preeti, and Shashi Kanta Varma. 2011. Entrepreneurial Activities of Self Help Groups: Instrumental for the Empowerment of Rural Women. Saarbrucken: LAP LAMBERT Academic Publishing.

SIDA (Swedish International Development Cooperation Agency). 2004. The Informal Economy. Fact Finding Study. Available online: http://www.rrojasdatabank.info/sida.pdf (accessed on 9 March 2021).

Sotiropoulou, Irene. 2014. Greek economy as a failure of capitalist patriarchy. In World Economics Association Greece and Austerity Policies: Where Next for Its Economy and Society? Paper presented at the Conference of the World Economic Association, Online. October 20-December 21.

Stavridou, Marianthe. 2018. Business Ethics and Human Rights. The Industrial Involvement in the Embeddedness of the Tibetan Community in Rikon, Switzerland: A Case Study. 
In Diaspora Networks in International Business. Edited by Maria Elo and Minto-Coy Indianna. Cham: Springer.

Stavridou, Marianthe, and Sumon Vangchuay. 2017. Beyond Corporate Social Responsibility-A Human-Centred Approach to Business Ethics in the 21st Century. ATDF Journal 9, pp. 70-86.

Stiglitz, Joseph, Jean-Paul Fitoussi, and Martine Durand. 2018. Beyond GDP: Measuring What Counts for Economic and Social Performance. Paris: OECD Publishing. [CrossRef]

UNDHR (United Nations Universal Declaration of Human Rights). 1948. Available online: https://www.un.org/en/universal-declaration-human-rights/ (accessed on 9 March 2021).

UNFCCC (United Nations Climate Change Conference). 2015. Paris Climate Agreement. Available online: https:/unfccc.int/process-and-meetings/the-paris-agreement/the-parisagreement (accessed on 9 March 2021).

United Nations. 2015a. Sustainable Development Goal. Available online: https://sdgs.un.org/ (accessed on 9 March 2019).

United Nations. 2015b. Sustainable Development Goal 8. Available online: https://sdgs.un. org/goals/goal8 (accessed on 9 March 2019).

World Bank. 2019. World Development Report 2019. In The Changing Nature of Work. Washington, DC: World Bank, Available online: https://www.worldbank.org/ en/publication/wdr2019 (accessed on 9 March 2021).

Wry, Tyler. 2015. What impact does microfinance have on inequality? In World Economic Forum. Available online: https://www.weforum.org/agenda/2015/12/what-impact-doesmicrofinance-have-on-inequality/ (accessed on 9 March 2021).

(C) 2021 by the author. Licensee MDPI, Basel, Switzerland. This article is an open access article distributed under the terms and conditions of the Creative Commons Attribution (CC BY) license (http://creativecommons.org/licenses/by/4.0/). 

MDPI

St. Alban-Anlage 66 4052 Basel

Switzerland

Tel. +41616837734

Fax +4161302 8918

www.mdpi.com

MDPI Books Editorial Office

E-mail: books@mdpi.com

www.mdpi.com/books

\section{MDPI}


MDPI

St. Alban-Anlage 66

4052 Basel

ISBN 978-3-03897-778-0

Switzerland

Tel: +41 616837734

Fax: +41 613028918

www.mdpi.com 